\title{
A IDEOLOGIA DAS CLASSES SUBALTERNAS ATRAVÉS DAS FESTAS
}

Dissertação de Mestrado apresentada à Área de Concentração: Interfaces Sociais da Comunicação da Escola de Comunicação e Artes da Universidade de São Paulo, com exigência parcial para obtenção do Título de Mestre em Gências da Comunicação sob a orientação da Prof $^{\mathrm{a}}$ Dr$^{\mathrm{a}}$ Maria Nazareth Ferreira

SÃO PAULO 
This document was created with Win2PDF available at http://www.win2pdf.com.

The unregistered version of Win2PDF is for evaluation or non-commercial use only.

This page will not be added after purchasing Win2PDF. 


\section{A IDEOLOGIA DAS CLASSES SUBALTERNAS ATRAVÉS DAS FESTAS}

Dissertação de Mestrado apresentada à Área de Conœntração: Interfaces Sociais da Comunicação da Escola de Comunicação e Artes da Universidade de Sáo Paulo, com exigência parcial para obtenção do Título de Mestre em Gências da Comunicação sob a orientação da Prof ${ }^{a}$ Dra Maria Nazareth Ferreira 
This document was created with Win2PDF available at http://www.win2pdf.com.

The unregistered version of Win2PDF is for evaluation or non-commercial use only.

This page will not be added after purchasing Win2PDF. 
Dias, Amarildo Ribeiro

A Ideologia das classes subalternas através das festas. São Paulo: ECA/USP, 2009

$201 \mathrm{p}$

Dissertação (Mestrado) Universidade de São Paulo Escola de Comunicação e Artes.

Área de Concentração: Interfaces Sociais da Comunicação

Orientadora Prof ${ }^{\mathrm{a}} \mathrm{Dr}^{\mathrm{a}}$ Maria Nazareth Ferreira

Palavras-chave: Armas ideológicas; subjetividades; sensos de propriedade e reciprocidade; deslocamento; convergência. 
This document was created with Win2PDF available at http://www.win2pdf.com.

The unregistered version of Win2PDF is for evaluation or non-commercial use only.

This page will not be added after purchasing Win2PDF. 


\section{Comissão Julgadora}

1.

2.

3. 
This document was created with Win2PDF available at http://www.win2pdf.com.

The unregistered version of Win2PDF is for evaluation or non-commercial use only.

This page will not be added after purchasing Win2PDF. 
ESTE TRABALHO É DEDICADO:

A todos os que forem capazes de conceber e adotar a filosofia da práxis, excluírem de si próprios qualquer concepção de classe e aos que persistirem em manter a consciência inalienável.

As pessoas nas quais durante este período do trabalho de pesquisa e dissertação, pude perceber um confuso olhar de surpresa, se perguntando como e por que ele tanto lê e tanto escreve? Fizeram-me pensar na necessidade de liberdade. Liberdade para que o individuo possa preencher o espaço do pensamento antes com o saber, não com as condições.

As pessoas em cujas palavras, pude perceber subseqüente real deslocamento.

A qualquer trabalhador que reconheça em si o senso de propriedade com a ferramenta. $E$, também àqueles que empenharam e empenham seus esforços intelectuais na compreensão das relações materiais humanas.

A ideologia da humanidade. 
This document was created with Win2PDF available at http://www.win2pdf.com.

The unregistered version of Win2PDF is for evaluation or non-commercial use only.

This page will not be added after purchasing Win2PDF. 
AGRADEÇO

Em primeiro lugar, a Neca, pelo Amor, por toda a ajuda, e por me dizer sempre, "vai dar tudo certo."

A Dona Dalva. Primeiro por cuidar do Nino, depois por me levar a concluir que qualquer loucura, pequena ou grande é melhor que o quarto escuro da ignorância e do conformismo.

A Suzete pela garra e, ao Tadeu pela argüição.

A Fabiana e aos colegas do CELACC. Soledad e Dennis pelas observações consideráveis no exame de qualificação; Maíra, pela atenção; Moisés, pelas boas dicas; Kátia, Henrique, Gerson e João.

Ao Jô Amado pelo abstract

A Rô e ao Paulinho.

Ao Renato.

Ao Jú e ao Zico.

A Cristiane e Seu Augusto.

Ao Ivan Vilela

Aos Professores Eclea Bosi, Zilda Márcia, Tadeu de Campos e Jonas Mansur.

As Pessoas que acreditam e se empenham nas possibilidades alternativas. E aos que perseveram na manutenção das manifestações expressivas da cultura popular subalterna: Dona Didi, Seu Vicente Rocha, Seu Canhoteiro, Beth, Seu Raul e Dona Helena (pelas pamonhas), Robertinho e esposa, seu Pedro, Seu Dito Motor, Seu Dito Gino e Seu Dito Prado, Seu Zé Maria Bonifácio.

A todas as pessoas que direta ou indiretamente colaboraram com este trabalho.

Em especial ao Nino que me fez perceber que é preciso parar e cuidar da vida.

Ao Chico por compartilhar seu vidro de pimentas.

E a Nazareth por nos conduzir para fora da caverna. 
This document was created with Win2PDF available at http://www.win2pdf.com.

The unregistered version of Win2PDF is for evaluation or non-commercial use only.

This page will not be added after purchasing Win2PDF. 
RESUMO

Neste trabalho, o objetivo central é contribuir para a formulação de um aporte teórico, concernente às Ciências Sociais, na área das relações entre Comunicação e Cultura sobre o conteúdo político-ideológico implícito nas manifestações culturais das classes subalternas e examiná-lo enquanto instrumento ampliador da margem de compreensão sobre as formas de produção e auto-reprodução destas classes.

Através da metodologia dialética, estudamos as possibilidades de identificar, na esfera das manifestações populares subalternas, indicativos da presença de potenciais ideológicos mediante os níveis verificados de sublevação do homem perante processos de homogeneização do pensamento, em contradição às condutas de resistência, automovimento e auto-governo reais.

Constatamos, nestes estudos, que as metodologia e filosofia historicistas atualmente estão predispostas às necessidades de transformação da sociedade. Identificamos sua base ideológica nas subjetividades de dispositivos sócio-culturais que da realidade das classes subalternas deverá vir à superfície através da práxis filosófica que conceba o nexo mundo-cultura-movimento.

\section{PALAVRAS-CHAVE}

Armas ideológicas; subjetividades; sensos de propriedade e reciprocidade; deslocamento; convergência. 
This document was created with Win2PDF available at http://www.win2pdf.com.

The unregistered version of Win2PDF is for evaluation or non-commercial use only.

This page will not be added after purchasing Win2PDF. 


\section{ABSTRACT}

The primary aim of this work is to help developing a theoretical contribution, concerning Social Sciences, to the area dealing with Communication and Culture.

Essentially, it discusses the political-ideological content underlying cultural expressions of the subordinate classes, which is identified as an expanding instrument of the understanding limits concerning the means of production and self-reproduction of these classes.

Through a dialectical methodology, we have studied the possibilities of identifying, in the scope of popular subordinate expressions, symptoms of the presence of ideological potential - by evaluating the level of human rebellion when faced by procedures of homogenizing thought, as opposed to resistance behaviour, real self-movement and selfgovernment.

We have established, in this important occasion, the predisposition of historicist methodology and philosophy to the needs of changing society. Furthermore, we have identified its ideological basis in the subjectivities of social and cultural devices which, from the reality lived by subordinate classes, will only come forward through a philosophical praxis that will conceive the nexus of world-culture-movement.

\section{KEY WORDS}

Ideological weapons; subjectivities; meanings of property and reciprocity; displacement; convergence. 
This document was created with Win2PDF available at http://www.win2pdf.com.

The unregistered version of Win2PDF is for evaluation or non-commercial use only.

This page will not be added after purchasing Win2PDF. 


\section{SUMÁRIO}

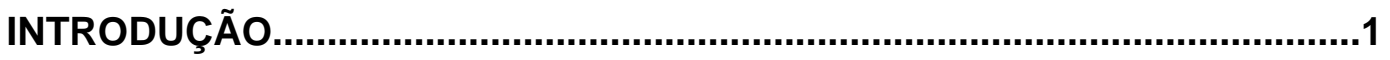

CAPÍTULO - 1 APONTAMENTOS TEÓRICO-METODOLÓGICOS .................22

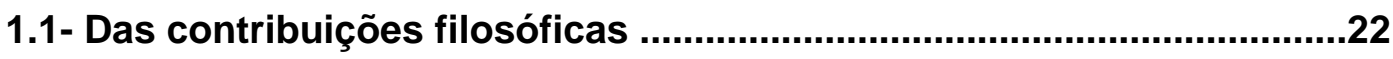

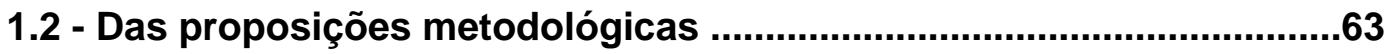

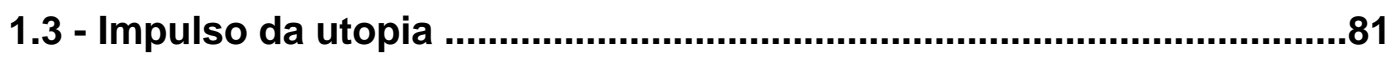

CAPÍTULO - 2 CONFIGURANDO A RESISTÊNCIA ...................................86

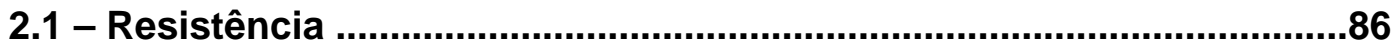

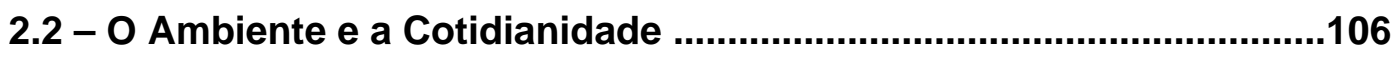

2.3 - Raízes históricas do Moçambique e do Jongo ...................................114

2.4 - Memória Coletiva, Memória Sensível e Comunicação - Dispositivos Ideológicos .............................................................................124

CAPÍTULO - 3 FESTA - AMBIENTE DA CONVERGÊNCIA .......................133

3.1 - Festa Popular Subalterna …...............................................................133

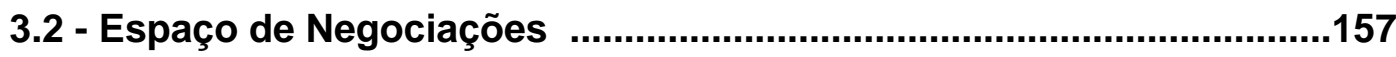

3.3 - Inserção - Intervenção ..................................................................163

CAPÍTULO - 4 CASQUETES, PAIÁS, FITAS, BASTÕES, ANGUÁIAS E

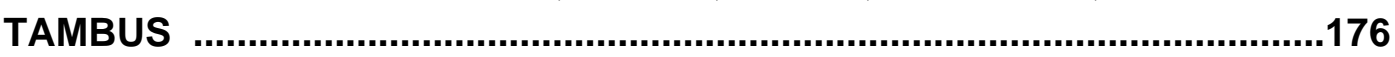

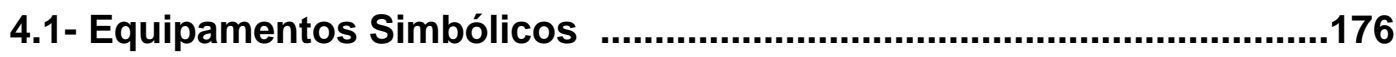

4.2 - Subalternidade e Marginalidade .......................................................184

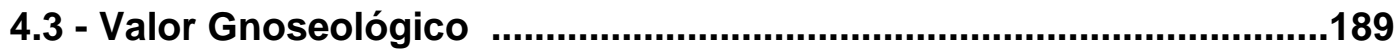

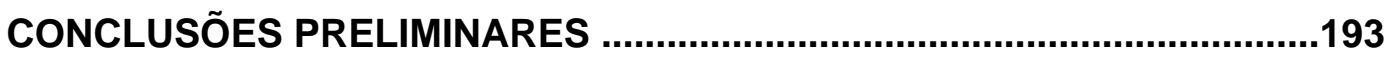

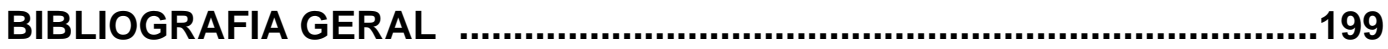

ANEXOS 
This document was created with Win2PDF available at http://www.win2pdf.com.

The unregistered version of Win2PDF is for evaluation or non-commercial use only.

This page will not be added after purchasing Win2PDF. 


\section{INTRODUÇÃO}

A presente proposta se insere na Linha de Pesquisa sobre Comunicação e Cultura, junto ao Centro de Estudos Latino-Americanos sobre Comunicação e Cultura (CELACC). Centro este que tem enquanto seus objetivos, a promoção e realização de pesquisas, cursos, seminários, consultorias, edição de publicações e outras atividades de natureza acadêmica; a criação de acervo documental sobre cultura brasileira e latino-americana; e a cooperação com a Universidade de São Paulo (USP), e outras instituições de ensino, de pesquisa e de produção científica, no sentido de divulgar os conhecimentos adquiridos.

Considerando-se o interesse e os aprofundamentos deste Centro em estudos voltados para a Comunicação e a Cultura como áreas de conhecimento, e também fonte inesgotável de questões pertinentes às atividades humanas, a proposta de pesquisa que aqui apresentamos, aborda política e filosoficamente a possibilidade de identificação da ideologia implícita nas formas de manifestação cultural das classes subalternas que se configuraram a partir dos modos de relação com a cultura e em seu interior. E que, de maneira abrangente, são ainda reflexos e sub-reflexos do impacto que muitos povos sofreram nos processos de colonização, ao enfrentar distorcidas ideologias que serviram de base para o racismo, para a eugenia, para a escala do esgotamento, para os monopólios, enfim para as ações hegemônicas das classes dominantes. Por estas condições, estes povos-nações, e quaisquer outros tipos de sociedade, vitimados por aqueles processos, ainda hoje buscam oportunidade de emergir para uma autonomia econômica, desenvolver seu plano de conhecimento científico baseado em suas razões de ser, sua organicidade: cultura-intelectualidade-sociedade; é preciso que se leve em conta a extensa gama de estudos já realizados sobre o tema em questão.

Este trabalho põe-se a distância de qualquer pretensão às verdades absolutas ou de apresentar convicções unilaterais, "é possível prever 'cientificamente' 
apenas a luta;"1 o que buscamos aqui é dar relevo à possibilidades de em um impulso da utopia deslocar a marcha para a (re)-humanização e a realização político-ideológica do sujeito histórico das classes subalternizadas; nesta condição como resultado de processos civilizatórios e ainda por perdurar a desconsideração às grandezas culturais que Ihes são intrínseca.

Acercamo-nos da convicção de que muitas das perguntas ainda continuarão sem as devidas respostas, tanto por não ter a humanidade ainda atingido, nível de consciência para tanto, mas, principalmente por ter-se a necessidade ao menos da perspectiva de um horizonte, utópico, porém capaz de deslocar e impulsionar uma caminhada. Importa que os passos cada vez mais possam ser compartilhados e usufruídos de forma mais autônoma, no saber, nas vivências; da mesma forma para o indivíduo das estatísticas como para o das massas; que neste itinerário por onde a espécie humana possa experimentar o conhecimento, que a humanidade, não como condição, como um todo, alcance plenitude.

Trata-se do estudo das possibilidades dos efeitos comportamentais gerados por sistemas de comunicação humana, garantidores dos processos de transferências e manutenção dos saberes, do conhecimento e da filosofia da práxis; a princípio pelo estabelecimento dos saberes e conhecimentos como tais, mas, subseqüentemente por terem completa correspondência com a representação histórica relativa a determinados período e regionalidade. Estas são significativas quando assimilam à práxis que se traduz em desenvolvimento sócio-econômico-cultural (viver em sociedade; ter de produzir e se auto-reproduzir; e, definir os caminhos para isso). Tais sistemas são da mesma forma, considerados, nesta abordagem como elementos aglutinadores, responsáveis pela conservação de núcleos conciliares, cujos mecanismos para esta manutenção estão entre as manifestações da expressividade que imprimem cadências ao cotidiano (o trabalho, o descanso e a festa). Sendo observáveis através e nas manifestações culturais, neste trabalho especificamente, confere-se a estas manifestações integralmente fundadas na relação de reciprocidade proprioceptiva entre a cultura das classes subalternas

\footnotetext{
${ }^{1}$ GRAMSCI, Antonio. Concepção dialética da história. Rio de Janeiro: Ed. Civilização Brasileira, 1966, p.162
} 
e as condições objetivas de trabalho, irrevogável importância. Nestas manifestações se evidenciam e ao mesmo tempo se consolidam enquanto saber, dentro e através do que ainda pode-se constatar do conjunto das festas populares. Popular, por um lado, pois existe o Estado que pré-estabelece uma rede distributiva classista que pretende determinar que haja o que não seja popular. Por outro, por se tratar da capacidade objetiva da linguagem, em tornar-se popular. As festas que são por sua vez, fenômenos da convergência, ambientes estabelecidos e historicizados no conjunto da sociedade civil, compreendem o aspecto de populares quando se realizam no indivíduo e com ele. É inexoravelmente um dos fenômenos catalisadores da relação natureza humana/cultura por suas linguagens e condutas. A esta essencialidade da festa, como fenômeno da convergência, corresponde à necessária complementaridade, no cotidiano, entre (cons)-ciência e ação. Isto é, embora a festa muitas vezes seja comumente entendida como um exacerbado momento orgiástico, não se desvencilha de sua carga de razões sócio-econômicas e culturais. Não há, neste sentido o que se possa dissociar. Tudo o que acontece está engrenado em algum conjunto das relações de produção e, por conseguinte, os elementos culturais componentes de uma festa popular, pressupõem, por exemplo, vias de abordagem metodológica das questões referentes à cultura popular e do "fenômeno relativamente novo da cultura de massa"; dentro de um sistema geral de crises, uma em especial qualitativamente confere-se a cultura correlata a "sociedade de massas" 2 . Portanto, sendo a cultura o complexo de comportamentos com os quais os indivíduos formulam suas sociedades, tem sido este, porém o campo onde insistimos nos aprofundamentos, com o objetivo de descortinar reais contradições a partir da observação do que foi ou está sendo dissolvido, diluído ou dissociado no conflito cultura/sociedade desencadeado neste sistema de crises.

A evocação da dimensão classes subalternas, está conscientemente empregada como qualitativo das classes dentro das quais estas manifestações culturais, objetos da investigação, encontram se em plena consonância; porém tratar-se-á sempre da tentativa de fugir da subsunção formal, qual seja uma

\footnotetext{
${ }^{2}$ ARENDT, Hanna. Entre o passado e o futuro. São Paulo: Ed. Perspectiva, 1972. p. 248
} 
impressão imagética decalcável. Funciona como distintivo de diferenciais hierárquicos esquizofrênicos. Tratamos sim da articulação para se fugir de uma condição de inferioridade decretada e, logo assumida dentro de um organismo social onde prevalece a hegemonia ideológica da mais-valia. A visagem distorcida de uma cultura elevada está associada, desde o advento do valorde-troca, ao preço que se pode ou deve se pagar; em qualquer escala, - local ou global - de onde podemos afirmar que oportunidade de acesso e portabilidade, são também hoje sinônimo de cultura. Hoje compramos acesso, pagamos pelo tempo de conexão com a cultura. Não se pode, no entanto perder de vista que o virtualismo (extasiante), preponderante nesta prática, em nosso entendimento, planifica bidimensionalmente as relações humanas, de acordo com a disponibilidade de acesso; enquanto a perspectiva, tanto conceitualmente no sentido de uma relação sem profundidade, quanto à percepção da externalidade, quando já englobam as percepções sensoriais, é proporcionada virtualmente. A contradição a ser observada aí, que decorre do momento em que a "sociedade começou a monopolizar a 'cultura' em função de seus objetivos próprios," ${ }^{3}$ é que, sendo a concepção do homem no mundo baseada em suas relações materiais, estas devem passar a considerar 0 aspecto não material destas relações que são capazes, por sua vez, de comoção; porém são ainda concretamente incompletas - relações materiais virtuais, relação de propriedade inefável - por isso o ponto crucial da questão, em nosso entendimento encontra-se entre as subjetividades das relações de trabalho. É preciso ressaltar, entretanto que não nos basta a idéia de que somente "o que durará através dos séculos pode se pretender em ultima instância um objeto cultural. ${ }^{44}$ Com esta afirmação, não se encontra superada a visão idealista de um simbologismo cronológico de alguma coisa ou fenômeno representativos de algum lugar, um tempo e de formas de pensar - por si não é capaz de nenhum movimento - é preciso que da cultura, ou de um objeto cultural, seja ele novo ou antigo, se desprenda alguma dinâmica social. A cultura tem por natureza o seu próprio recriar-se, alimenta-se do cotidiano das coisas em congruência dialética com o preservar-se, interpretado habitualmente por hora como resistência. Outra ressalva a ser feita, para não

\footnotetext{
${ }^{3}$ Ibid., p. 254

${ }^{4}$ Ibid., p. 255
} 
se incorrer em uma conduta de secção, diz respeito a não se confundir nem compactar subjetividades em "um hiato no ciclo de trabalho condicionado biologicamente", como um vazio que divide os tempos; ambos, subjetividades e caso exista este hiato se amalgamam plenificando o "metabolismo do homem com a natureza" ${ }^{5}$ - aqui, as relações materiais - a ludicidade realística do cotidiano traduz-se em senso de propriedade. Opõe-se ostensivamente à ideologia cujo poder por ela sustentado, atua predominantemente sobre a comunicação instituindo o padrão e o fluxo do pensamento proporcionalmente hegemônico em correspondência com este poder; cabe-nos fugir a este extremo de prostração mediante as forças do capitalismo, constantemente recém-maquilado, paradoxalmente com feições culturais.

Conquanto a parcela mais significativa dos que se enquadram neste qualificativo de classe subalterna, esteja hoje em desvantagem com relação ao oferecimento de serviços públicos e mesmo à margem do consumo insinuante, apesar de, em muitos casos, habitarem os centros urbanizados das cidades, sofrem ademais, o efeito dos intensos processos de desterritorialização (uma espécie de dissolução do ambiente). Por isto são obrigados tão somente a deslocamentos espaciais (êxodos), conforme a expansão dos centros (comerciais nervosos) de interesse. Trata-se de um obrigatório e inevitável deslocamento espaço-temporal histórico quando se dissolve a base de interação vital da sociedade. É possível então, questionar, se estes atores, pertencentes a estas classes, necessitam irrestritamente do poder do capital para a manutenção de sua cultura? Acreditamos tratar-se de dois vieses explicativos de uma mesma questão; de um lado tudo que compreender o modo de ser, ou seja, a maneira como indivíduos e grupos de indivíduos concebem o mundo, articulando com ele e dentro dele e, de outro, o ponto de vista que os consideram excluídos do padrão mercantil, (neo)-liberal, evidenciando que o que não está oficializado pela classe dominante é "popular - subalterno"6. Isto é, não participa politicamente da ordem social, funcionam como adereços de identificação - insígnias. Entendemos que tais modos, de maneira contundente, têm conteúdo ideológico próprio e predisposto à

\footnotetext{
${ }^{5}$ Ibid., p. 258

${ }^{6}$ FERREIRA, Maria Nazareth. Cultura Subalterna: a encruzilhada da América Latina. São Paulo - Celacc Eca Usp, 1997, p. 30
} 
negociação, É, portanto imprescindível que existam, resistam e se reproduzam sem rótulos, nem embalagem com o valor descritivo impresso.

Nestas observações encontram-se definida, no rol das Ciências Humanas, as proposições metodológicas que se pretendem para o exame destas práticas culturais. Primeiramente, estreitando o foco da linha de pesquisa dentro da relação entre Comunicação e Cultura; visualizamos as possibilidades de identificar nas subjetividades destas relações de trabalho, a crença de que

[...] a partir do momento em que um grupo subalterno torna-se realmente autônomo e hegemônico, criando um novo tipo de Estado, nasce concretamente a exigência de construir uma nova ordem intelectual e moral, isto é, um novo tipo de sociedade e, conseqüentemente, a exigência de elaborar os conceitos mais universais, as mais refinadas e decisivas armas ideológicas. ${ }^{7}$

E, munidos deste arsenal iniciar a "luta por uma cultura superior autônoma"8 dentro da qual acreditamos, se encontra a fonte de humanização da sociedade.

O enfoque aqui adotado traz possibilidades inúmeras de abordagens e, sobre o qual, muitos debates e registros já foram dados. É igualmente desnecessário tentar restringir e cercear outras questões e debates em face da amplitude do conjunto das tematizações às respectivas manifestações populares subalternas; a estas, aqui, vemos especialmente como equipamentos simbólicos de manutenção das dinâmicas sociais e sistemas de cultura. Há que se considerar as inúmeras possibilidades de conteúdos correspondentes à diversidade que se demonstram alternadamente ora com foco sobre a questão da resistência, ora como leitmotiv para preservação dos costumes ou das crenças visando à obtenção, por exemplo, de um perfil sociológico estatístico do elemento humano, brasileiro e latino-americano ou de distintas culturas.

Diante de um cotidiano de transformações brutais da ordem mundial, indivíduos que preservam e instruem seus descendentes em formas tradicionais de expressão, em torno dos quais se edificaram fundamentações para a vida

\footnotetext{
${ }^{7}$ GRAMSCI, Op. cit., p. 100

${ }^{8}$ Ibid., p. 100
} 
comunitária, constituem um campo promitente para um vislumbrar do sujeito histórico e sua concepção do mundo. Ora no canto de trabalho, ora no louvor e na dança, nos pontos das Rodas de Jongo e nas ladainhas da Dança do Moçambique compreendem-se de forma abrangente, diversos aspectos das relações humanas e da divisão social do trabalho e conseqüentemente a construção objetiva da relação do homem com o mundo.

Enquanto representam, são guerreiros, das cores, dos sons, dos guizos; dos manejos dos bastões e das gingas nos bailados, travando uma batalha com o que se projeta na tela do tempo/espaço. Não são simples movimentos e atributos, são saberes organizados que evoluem em ciclos distintos, observando períodos e fases dentro da cronologia da história e, em meio a esta cronologia, se confundem no conceito petrificante de folclore, se reproduzindo no atual contexto apenas como produto/imagem - mercadoria. Há que se percorrer caminhos de ida e vinda na historicidade destas manifestações e, decodificar emblemas representativos de periodicidades para que se estabeleçam ordem e sentido correspondentes às necessidades atuais de compreensão, nesta, apreendemos, como significativo conhecimento sobre o homem e sua atividade englobando suas diversas índoles, até mesmo a estética se considerarmos sistematicamente o enunciado de F. Shiller:

[...] Todas as coisas que de algum modo possam ocorrer no fenômeno são pensáveis sobre quatro relações diferentes. Uma coisa pode referir-se imediatamente a nosso estado sensível (nossa existência e bem-estar): esta e a sua índole física. Ela pode também referir-se a nosso entendimento, possibilitando nos conhecimento: esta é sua índole lógica. Ela pode ainda referir-se a nossa vontade e ser considerada como objeto de escolha para um ser racional: esta é nossa índole moral. Ou finalmente ela pode referir-se ao todo de nossas diversas faculdades sem ser objeto determinado para nenhuma isolada dentre elas: esta é a índole estética. [... ${ }^{9}$

Este pensamento cerceia e limita à concepção estética das relações humanas, desconsiderando o conflito e os conflitantes, os contrários e as contradições a irregularidade e a multiplicidade destas relações, mas, não deixa de implicar

\footnotetext{
${ }^{9}$ SHILLER, F. A educação estética do homem. São Paulo: lluminuras, 2002, p.103
} 
com certa abrangência a conduta humana. Em outras palavras, não deixa de implicar suas sensações, seu pensamento e sua moral.

Ressaltamos que as verdadeiras contradições na conjugação de valores materiais e não-materiais dentro deste universo imaginário, pleno de representatividade, compreendem a possibilidade de um salto qualitativo através da manifestação expressiva que conduz a sociedade a escapar ao conformismo. Nosso intuito é o de ampliar o campo das teorias comprobatórias da possibilidade de alternativas metodológicas para se pensar a realização e a (re)-humanização do sujeito, cujos instrumentos e armas, entendemos, estão implícitos na cultura das classes subalternas. "O homem é ai, antes de tudo, uma subjetividade capaz de atribuir sentido ao mundo, transformando os dados da realidade sensível em objeto do conhecimento, graças aos recursos da racionalidade." 10

Com toda estafa o homem é ainda uma concretude capaz de produzir conhecimento, ou seja, transformar o desconhecido em cognoscível, investigável. Tomando como base tópicos importantes dos estudos gramscianos, inúmeras são as chaves para se alçar a problemática que aqui se apresenta; porém duas são destacáveis: o conceito de classes subalternas, que em analogia ao tema pretendido qualificativamente expande-se para o de cultura das classes subalternas; nestes estudos, como acima indicado, esta concepção de cultura é essencial dentro das considerações à filosofia da práxis - a outra chave tomada ao pensamento gramsciano se refere à comunicação social. Na mesma linha de pensamento, instrumento primário para a difusão da ideologia, pois perpassa as organizações que por inserção ou intervenção, propriamente culturais ou que somente incorporam qualquer fração da cultura por identitário; de qualquer forma não funcionam sem a ideologia. O folclore é uma resultante da ideologia que costuma refletir, na aparência, uma dinâmica de cultura representativa, que não traz substância às subjetividades. É preciso que se atente para as incongruências que se estabelecem entre uma religião ou moral popular e as convicções patrimoniais e individuais do intelectual. Inicialmente para que estas (religião ou moral) não representem um abismo intangível. Acuidade maior, principalmente quando o objetivo é o se verificar

\footnotetext{
${ }^{10}$ SODRÉ, Muniz. Reinventando a Cultura: A comunicação e seus produtos. Petrópolis, RJ: Vozes 1996, p. 41
} 
aspectos da objetividade, não restritivamente na aparência, no fenômeno, mas no conjunto das subjetividades que consubstanciam inerentemente as práticas culturais. Este conjunto, diz respeito ao afetivo e ao cognitivo; por isso são objetos da filosofia. A comunicação social pode ser e tem sido adotada como instrumento de dominação da ideologia; apesar de sua dinâmica evolutiva e expansiva, não "deixa de cumprir, dentro dela, uma função ideológica determinada". ${ }^{11}$ A este ponto, já não se admite concluir que haja um princípio de exclusão quando se considera o raio de abrangência e a maneira como são respeitadas as formas expressivas. Em outras palavras, não estariam algumas formas de manifestação da cultura subalternizadas de maneira a subsumir este condicionamento como modelo de função política no sistema? Não estariam estas formas de manifestação respeitando cega e inquestionavelmente uma ordem difundida que determina que a cultura deva ter seu lugar na sociedade ao invés de compreender que cultura é a forma primordial de concepção, apreensão e transformação?

Dentro de uma concepção dialética de unidade em que coerção, consenso e transformação, se inter-relacionam ou se interpenetram, objetivamos questionar até onde se pode comprovar, seguindo as teorias, até aqui ainda superficialmente expostas de uma parcela ínfima dos concisos estudos gramscianos, que já se encontram esgotadas as possibilidades de realização do sujeito, quando uma das premissas é a luta por um vinculo cada vez mais orgânico entre Estado e sociedade civil, entre uma filosofia historicista e o desigual desenvolvimento humano? Até que ponto se pode pensar em momentos para estancar a questão da cultura conferindo-se promissão científica a análises puramente estéticas e elementares, quando se toca ao conjunto das manifestações sócio-culturais, enquanto por outras vias de abordagem, para uma apreciação ainda mais integralizadora do sujeito sóciocomunitário, as subjetividades nas relações de trabalho, concebidas por uma metodologia mais historicista e dialética de aproximação ao objeto, permitem a continuidade das teorizações a respeito do que sejam as forças sociais. Com base nesta segunda questão:

\footnotetext{
${ }^{11}$ PORTELLI, Hugues. Gramsci e o bloco histórico. Rio de Janeiro: Paz e Terra, 1997, p. 27
} 
O indivíduo-cidadão daí resultante é um fato ideológico. Dele partem as ciências sociais e humanas para a formulação do objeto teórico chamado "sociedade moderna". As modernas concepções sócio-filosófica em torno da essência do humano assentam-se numa mesma base doutrinária, que entroniza o valor-indivíduo [grifo do autor]. ${ }^{12}$

O que se pode intuir é que a possibilidade de tomada da concepção de homem e do mundo, projetada ao campo das manifestações culturais expressivas, pois é a expressão do intrínseco no homem extrínseco, como objetos da investigação científica, está longe de ser esgotada, e por esta consideração, aos modos de relação com a cultura como fator elementar para socialização e reciprocidade circunstantes do senso de próprio, muitas leituras são eminentemente necessárias e outras fundamentais; ainda que seja razoável se perguntar como e a quais formas de manifestação cultural se projetar tal possibilidade:

A obra antiga, a obra moderna, a mercadoria cultural, a atualidade artística.

Qual o sentido da arte diante da tecnocultura?

Parte do desejo, do sujeito na direção do objeto, passa pela subjetividade, por um movimento inconsciente que está fadado à radical insatisfação, pois seu objeto se define pela falta com relação ao real; não tem valor de realidade.

As estratégias publicitárias se empenham em "produzir a necessidade de consumo, revestindo-a da suposta irrealidade do desejo e atribuindo-lhe, claro, um preço. Um produto qualquer, do eletrodoméstico a uma narrativa, é significado como algo que transcende o seu banal, valor de uso imediato, impondo-se como desejável, por ser caucionado pelo desejo de 'outro' - a grande organização comercial ou industrial, o criador da moda etc." "Nem a obra de arte escapa do mercado". ${ }^{13}$

À iniciativa que no momento se apresenta, importa a experiência do testar mais uma das portas que dá acesso a um cominho que poderá, cremos,

\footnotetext{
${ }^{12}$ SODRÉ, Op. cit, p.45

${ }^{13}$ Ibid., p.102
} 
contrapondo um ostracismo hermético em que caíram importantes estudos, conduzir ao processo contínuo de tornar cognoscível algumas das diversificadas e intrincadas facetas desse estágio do desenvolvimento humano - sob o móbil da minimização das desigualdades sociais -; não se pretende, porém, divagar inutilmente sobre uma inconcebível equiparação sócio/econômica e tecnológica entre as nações, mas, face ao desenvolvimento da comunicação social, como um fluído que percorre velozmente muitos espaços simultaneamente, que ela permita ao menos, maior e mais extensiva compreensão sobre o atual conflito das identificações -; uma identidade colhida na prateleira dos magazines transculturais traduz o indivíduo sóciocultural pós-moderno? As grandes transformações e as revoluções mais significativas, em confronto com as circunstâncias e sistemas experimentados, foram e ainda são, em muitos casos, processos lentos; pois, iniciamente demorava-se na compreensão para que depois se articulassem as marchas revolucionárias; quase sempre não sem liderança, também não sem contingente; porém jamais sem a comunicação. Prestando esta, sempre à fixação da ideologia no senso-comum, conforme o nível já atingido de conceituação e também da tecnologia. Assim, hoje não se poderia perdurar qualquer dúvida de que a compreensão deveria se dar de maneira mais rápida e mais abrangente; entretanto o que não se encontra definido até o momento é: com as informações em alta freqüência de circulação, a que tipo de esclarecimento se pretende chegar e o que se faz com ele; produz se riquezas para salvaguardar os grandes capitais ou salva-se o planeta e a humanidade? Pergunta-se, teria algum valor pensar, que se encontra em fase preparatória alguma nova revolução, contra o que ou quem, e, de que movimentos se conduziria? O uso banalizado desta palavra, revolução, não destitui sua força em si; remete imediatamente a insurreição das massas. Traduz sempre o embate entre opostos - opressão/liberdade -; pode caracterizar-se por mudanças profundas ou sutis, mas nunca se esvazia de motivação política envolvendo dominantes e dominados. A primeira revolução técnica tratou da introdução das ferramentas na relação homem/natureza, cerca de dois milhões de anos a.C., compreendendo a descoberta do fogo e a refeição em grupo. Somente a espécie humana, na natureza consegue alterar os sistemas; estrutura esquemas de hierarquias conforme o predomínio da força, da astúcia, 
do discurso, domínio tecnológico, foro privilegiado, informação, dinheiro. A segunda revolução importante na história humana, podemos assim considerar, diz respeito ao desenvolvimento da agricultura, à descoberta do sedentarismo, às cidades, ao acumulo de riquezas, destacando-se os mais fortes, os mais hábeis e os mais ricos, sempre dominando e se apropriando do excedente da produção. Já entre os sumérios em 2415 a.C, questionavam-se, não somente as leis, mas a exploração nos procedimentos do Estado. A primeira Democracia, de Sólon, na Grécia em 2600 a.C; depois, a Nova Democracia ainda não contemplava a participação política das mulheres e dos escravos, mas instituía a assembléia geral, para a garantia de quorum; uma milícia capturava cidadãos pelas ruas que eram obrigados a participar. Um lema, diretamente oposto à ordem estabelecida, as privações ao alimento, privação da liberdade e do voto são suficientes para provocar uma insurreição, como foram as revoluções francesa e a americana, na primeira contra os esbanjes da monarquia e as privações da classe mais pobre; e, entre os americanos, contra o domínio dos ingleses, onde o consenso gerava mais que uma classe. Thomas Jefferson resumiu o ideal revolucionário: vida, liberdade e direito à busca da felicidade. Na França, anos mais tarde seria promulgada a declaração dos direitos humanos. Aqui uma ilustração nos fatores para independência dos americanos: na cidade de Boston promoveu-se a Festa do Chá, onde camponeses, disfarçados de índios ritualisticamente, atiravam caixas de chá nas águas do lago, revoltados com as imposições dos ingleses sobre a mercantilização do produto; para os revoltosos, contudo, o disfarce de índio era uma forma de auto-afirmação do tipo somos americanos, mas estes mesmos índios haviam sido dizimados pelos não-índios americanos na perspectiva de formação e expansão do Estado e do território norte-americano. A revolução, visando à derrubada do regime opositor, pode adotar um sistema cíclico evolutivo de sobreposição de ideologias, cada vez que se criam mecanismos de distinção de classes, como se comprova nos discursos partidários. Assim, esgotam-se as propriedades lingüísticas até que a expressão não tenha mais um fundo nem força; passa a não fazer mais sentido e não servir além do que o faz na propaganda coloquial consumista (a geladeira revolucionária, o revolucionário sistema de ar condicionado, etc.). 
Liberdade de expressão, de idéias e de movimento consubstanciou a revolução das máquinas e das mentalidades; a Revolução Industrial transformou o camponês em operário. Produção e produtividade ditam a lógica e a máquina a vapor estabelece a cadência no desenvolvimento urbano das cidades. Surge com os camponeses/operários a classe operária cuja maior ideologia era 0 marxismo na tentativa de uma revolução operária. Com a revolução sexual, não sem uma nova mentalidade, a reivindicação por novos espaços e modos de vida; criam força o feminismo e a mutação cultural, (re)-inventam-se representações efêmeras do ser humano. A propagação da idéia de uma fraternidade sem fronteiras suscitou a almejada aldeia global.

Entretanto os regimes governamentais autoritários sempre se apressam em controlar a mídia ${ }^{14}$. Destacam-se dois tipos de controle sobre a comunicação, um do tipo nacionalista que restringe o indivíduo à identidade nacional e outro, a censura, que apesar de destituídos os órgãos censores, as idéias são condensadas e formatadas segundo um modelo imperativo de bombardeio massivo da informação e dos produtos culturais midiáticos. Porém, a comunicação, sob controle ou não, nunca deixa de manter as idéias vivas e em movimento. Por isso a comunicação, como faculdade especialmente diversificada no ser humano, deve compor sempre as bases de formação da sociedade. Mas, para um idealizado compartilhamento das soluções, sem que se calculem os impactos sobre o cotidiano, computa-se tão somente a massificação da informação - a cultura de massa. Todavia, a nova modalidade distintiva entre os que têm, quanto tem ou não tem acesso à informação se amplifica e, o grande incômodo que continuará sendo a presença dos desfavorecidos; também continua sendo a matriz das ideologias dominantes produzir uma massa de necessitados. Assim, consideramos de extrema importância a historicidade do debate em torno desta problemática e, portanto, perguntamos, por quanto tempo mais? Também e acima de tudo, usando das reflexões de M. Hardt e Antonio Negri (2005), ressatamos que

[...] na medida em a produção social define-se cada vez mais por formas imateriais de trabalho como a cooperação ou a construção de relações sociais e redes de comunicação, torna-se

\footnotetext{
${ }^{14}$ BETHEL, Leslie; ROXBOROUGH, lan.(org) A América Latina entre a Segunda Guerra Mundial e a Guerra Fria. Rio de Janeiro: Paz e Terra, 1996, pp.72-77
} 
cada vez mais diretamente produtiva a atividade de todos na sociedade, inclusive os pobres. ${ }^{15}$

Entendamos que, formas imateriais de trabalho, não correspondem evidentemente à uma nova modalidade ou a uma nova concepção sobre o mundo do trabalho, mas à uma consideração mais abrangente das subjetividades nas relações de trabalho de onde nascem, evidentemente, novos trabalhos.

Assim, constatando-se historicamente os resultados, das grandes mudanças, à exemplo da revolução industrial, do caos ambiental etc., faz-se necessário perscrutar a vida do homem - sujeito/objeto - a fim de que em algum momento, a passos mais incisivos se apresentem às teorias e às práticas condensadas, segundo Gramsci (1966) em força social de transformação. A comunicação seguirá sendo o instrumento da abrangência; o conhecimento é imprescindível como mola propulsora das articulações e do deslocamento; contudo, falta definir ao que chegar e o porquê chegar, pois há tempos se têm estabelecidos os preceitos da democracia, da liberdade, dos direitos, que ainda não são plenos; em muitos casos permanecem como objetivos, em outros são ainda meras utopias. Como utopias, pressupõem-se também como princípio que desencadeia o movimento dialético da compreensão e da transformação, então, deve haver um horizonte utópico como lugar das possibilidades; como muitos que já foram e outros que deverão ser verificados, um desses campos e que acreditamos ainda poder ser examinado, a partir do que consideramos serem os conteúdos político, econômico e filosófico, estão entre as singularidades das atividades humanas, as festas populares subalternas. Oposto a isso, continuaremos a constatar, condicionadamente, os processos de aprendizagem indicados para que cada coisa esteja em seu devido lugar de funcionamento; ou então, esta aprendizagem continuará se dando como sempre, ou muitas vezes tem-se dado, através das catástrofes sociais, agora geradas pela marginalização e pela descolonização - Haiti, Senegal -; autonomia com dependência; as catástrofes ambientais, aquecimento global; e, as econômicas, redefinição dos atores e das posições no mercado transnacionalizado que se generaliza com o título de crise econômica mundial.

\footnotetext{
${ }^{15}$ HARDT, Michael; NEGRI Antonio. Multidão: guerra e democracia na era do Império. Rio de Janeiro: Editora Record, 2005,zp. 178
} 
Distinguidas respectivamente, as festas e as festividades, uma como ocasião ou circunstância, o presente, a dádiva e a outra, como estado de espírito, de humor, e correspondente demonstração deste estado; são historicamente espaços de tempo onde a concentração de pessoas é um dos principais objetivos e, certamente a persuasão ao consumo é hoje mais evidente devido à lógica mercantil vigente; e, esta mesma lógica também implica transformação de toda e qualquer singularidade em produto. É também social e historicamente a interface metodológica pela qual se buscou aqui corroborar com a ampliação das teorias já aplicadas na análise destas realizações; as festas e festividades bem como as manifestações culturais populares que as consubstanciam, são neste trabalho de pesquisa, contempladas sob diversos aspectos; dentre eles, a exemplo da ligação do homem com a terra (relações materiais) e, esta ligação como fonte originária de diversas formas de subjetividades: a sagração, pois que aqui se entende como ato de carregar de importância simbólica uma realidade concreta como o trabalho, por exemplo o trabalho é sagrado. As festas (Sagras), fundamentadas sempre em alguma tradição, trazem de algum modo uma correspondência com algum tipo de fruto da terra, produto da relação do homem com a natureza. Como nas mais antigas civilizações, o sentido de sagrar e consagrar alimentos e elementos da natureza para manutenção de provisões, para proteção contra algum inimigo ou as intempéries do tempo corresponde ao sentido de unidade em objetividade e subjetividade. Tomamos a esse respeito, o exame feito por Maria Nazareth (1998) em sua pesquisa sobre festas italianas:

Sagra quer dizer dedicar a Deus, aos deuses, tornar algo sagrado. O costume antigo de dedicar aos deuses determinadas colheitas é ainda hoje muito utilizado na Europa, principalmente na Itália, onde toda sorte da colheita é dedicada aos deuses, isto é colocada sob proteção das divindades sendo batizada de "sagras". [...] O nome de Sagra vem da antiga tradição "pagã" de saudar a produção da terra, oferecendo-lhe sacrifícios sagrados e grandes festas populares. Já na língua italiana mais antiga, este termo era usado com o significado de festa para comemorar uma grande consagração de um evento importante, ligado ao culto de um deus, ou dos santos. 
Mais tarde, o significado se estendeu às festas populares nas quais se celebram acontecimentos cíclicos, um particular momento do ano, deveria repetir-se, seja religioso ou profano.

Pelo costume, a palavra passou a significar também as feiras e mercados sazonais e os jogos e espetáculos que acompanham as festas populares. ${ }^{16}$

Devemos superar por hora os aspectos puramente metafísicos, para dar ênfase ao que historicamente se torna relevante e passa a demarcar os momentos significativos das relações materiais. Assim se pode considerar a profunda ligação do trabalho com a terra e o desenvolvimento de festividades, ou seja, do espírito festivo em decorrência de uma produtividade almejada e da empreitada em si. Não somente com a produtividade, como se fosse bastante 0 plantar e colher, há uma imensa consideração aos frutos em especial; e, é em torno da atividade que são tecidas as idéias, as alegorias e uma vasta gama de subjetividades; o senso de propriedade e as demarcações históricas da sociedade igualmente não fogem desta premissa.

Para se buscar pertinência e se chegar a proposituras mais consistentes dentro do debate sempre (re)-atualizado sobre comunicação e cultura, interessou-nos implementar as investigações nos campos aos quais identificamos, como neste ambiente das festas populares, face ao processo de democratização do acesso a cultura, o desconhecimento ou o arrefecimento das bases ideológicas de sustentação destas formas populares de manifestação. E, em razão deste arrefecimento, questionamos, onde e quais seriam as efetivas ações de resistência e de luta para se garantir a permanência dos referenciais mais importantes; não somente que diga respeito à preservação daquelas formas, mas, também por representar objeto fecundo para compreensão do homem no aspecto das suas subjetividades e consciência. Assim, o foco dividiu-se e ao mesmo tempo intensificou-se, sobre as naturezas formais e sensíveis das manifestações expressivas e seus acessórios correlatos, suas paramentações

\footnotetext{
${ }^{16}$ FERREIRA, Maria Nazareth. Cultura, Globalização e Turismo: a cultura subalterna como mercadoria. Relatório final de Pós-Doutorado. São Paulo: Escola de Comunicação e Arte da Universidade de São Paulo, 1998, pp. 225-229. Pesquisa realizada junto a Universitá Lá Sapienza di Roma
} 
e indumentárias, observados como equipamentos simbólicos de manutenção da existência da forma expressiva; considerados, nos respectivos processos comunicacionais como "material ideológico"17 a garantir continuidade histórica. Assim como se considerou importante também, aprofundar os questionamentos sobre as condições de subalternidade e/ou de marginalização frente o poder tecnológico dos dispositivos simbólicos de modernização da cultura, ${ }^{18}$ o processo de globalização e a comunicação em massa. A temática ainda permitiu-nos aprofundamentos dialéticos sobre o que inicialmente pretendemos chamar memória sensível. Memória à qual pensamos, esteja impregnada no indivíduo ou no coletivo e que responde ao estímulo de uma rememoração sensorial e subseqüente ação; isto quer dizer que, aquilo que dentro das relações materiais é capaz de reconduzir o homem ao senso de reciprocidade e de propriedade no contato com seu meio objetivo de produção. O que chamamos memória sensível está em completa correspondência com a já identificada memória coletiva, base incondicional da identificação histórica da sociedade.

A possibilidade de questionamentos e exames sobre estes tipos de memória, tem raízes no que alguns autores analisam sobre forma e conteúdo. Analisando aqui, alguns fragmentos do pensamento de Friedrich Schiller (2002) "é primeiro indivíduo e depois pessoa, caminha das limitações a infinitude. [...] O impulso sensível, portanto precede o racional, pois a sensação precede a consciência". 19

Prontamente discordamos da acepção de transcendência implicada no enunciado; cremos inicialmente que mesmo enquanto limitações não deixam de servir aos impulsos transformadores. Schiller é profundo seguidor de Kant. Em sua época, recebia de um nobre uma pensão, a quem escrevia cartas de suas observações individuais. Dificilmente em suas elaborações identificamos como motivadora a uma necessidade real. Assim, em seus escritos predomina

\footnotetext{
${ }^{17}$ PORTELLI, Op. cit. p.28

${ }^{18}$ SODRÉ, Op. cit. p. 85, passim

${ }^{19}$ SHILLER. Op.cit. p.102.
} 
o ideal de superação evolutiva de estágios até o estado de nobreza no homem. Mas, há certamente na historicidade da relação entre o homem e a natureza, instantes de predominância das relações materiais concretas; momentos nos quais tanto no indivíduo quanto na espécie, este impulso sensível é mais latente. Não pregamos a preservação do trabalho unicamente braçal, entendemos que, a relação material marca o homem com noções e ciências através das quais ele concebe o todo. Partimos então do princípio de que o trabalho, incluindo o físico e o mental, como atividade pela qual o indivíduo apreende o mundo, deva ser o terreno no qual se pode reconhecer, ou se deva construir as estruturas da sociedade humana. A sociedade, como conjunto de interesses racionais, só pode ser feita de seres racionais. Assim toda sociedade é de seres humanos. Entretanto, o conceito de sociedade vem sendo ultimamente, quase sempre, acompanhado de algum qualificativo, sociedade moderna, sociedade de consumo, sociedade capitalista, sociedade de risco, sociedade de risco, sociedade do espetáculo etc. Relevado o que faz jus ao senso comum, referimo-nos à períodos de contato mais freqüente e intensivo com os meios materiais, como matrizes das formas de relacionamentos, do como saber e como fazer. Por hora, mas sem que esqueçamos por completo, não interessa exatamente atribuir total importância a esta ordem idealista de ascendência do sensível ao racional, raiz da divisão de classes. Importa sim, considerar que, de um período ou fase de concretas relações materiais resultem subjetividades fundamentais na atividade humana. Não será difícil detectar no estudo da historicidade, respectivamente, que houve certamente, períodos de maior predominância deste impulso sobre o homem racional; período de prática e por isso mesmo seu caráter de provisório, até a chegada do desenvolvimento da filosofia; o que importou analisar, contudo, a partir deste pressuposto, uma vez que não há um equilíbrio pleno e constante neste jogo dos impulsos sensíveis ou racionais, sobre quais seriam e como podem ser lidas estas marcas impressas no espírito, naquele momento de tal predominância? Como o entendimento destas marcas atuaria sobre o individuo ou grupo de indivíduos no decorrer de sua história como um tendência sensível, bastando que um estímulo desencadeie-lhe a lembrança da sensação? Ocorrendo a lembrança e uma imediata identificação do homem em sua compleição física sensorial desta rememoração, haveria qualquer 
probabilidade de adesão daqueles procedimentos, ou técnicas ou comportamento sócio/cultural correspondente? De outra forma, ao se revelar nas subjetividades qualquer identificação sensorial, na memória sensível é possível se admitir, nesta identificação, um contraponto ou contra-discurso a ideologia de alienação do trabalho? Quando estas subjetividades tocam a esfera do lúdico, ou seja, a manifestação do cultural e tudo que ela envolve, sem se distinguir, por hora as intenções (políticas, religiosas ou estéticas), estes questionamentos podem ganhar mais consistência, pois que são notórias as identificações que se dão entre grupos distintos, de territorialidades distintas, e, no entanto, com traços comuns de corporeidade na manifestação da cultura (bailados, ritmos, tocar os instrumentos, o uso dos potenciais físicos). Acreditamos ser, bastante difícil que o indivíduo escape as rédeas e a dependência impostas pelo sistema capitalista. Da mesma forma acreditamos ser possível que o racional/sensível possa levar a vivência mais plena da compreensão.

Em outra abordagem, para o que se demandar como necessidade de compreensão sobre este aspecto do desenvolvimento histórico, neste paralelo entre memória sensível o que se considera como memória coletiva, valemo-nos do que destacou Sodré (1996) da reflexão de Maurice Halbawchs (1925): "memória coletiva" não é dar costas ao presente; é 'reconstrução do passado a partir da inteligência presente da vida social",20 de fato o indeterminado é o contexto onde intuímos ser possível observar circunstâncias em que o sujeito se humaniza ou é humanizado pela aproximação e fruição de uma forma cultural manifestante. É o momento em que o coletivo demonstra a si mesmo seu conteúdo e pertinência. Podendo ser esta demonstração, meramente narrativa ou em forma de vivência. Tratando-se dos estudos possíveis relacionados a estas modalidades de memória, acreditamos desenvolvimento de um raciocínio sobre como se configuram as bases de sua resistência, e o quanto poderá estar esta atitude, correlacionada aos conceitos de valor de uso e valor simbólico ${ }^{21}$, e aos sentidos de propriedade - próprio de, e próprio

\footnotetext{
${ }^{20}$ HALBAWCHS, 1925 apud SODRÉ, 1996 p. 84

${ }^{21}$ BAUDRILLARD, Jean. Para uma crítica da Economia, Sociedade e Cultura. São Paulo: Paz e Terra, 2000, p. 178
} 
para -; e de reciprocidade - o homem faz ao meio e o meio devolve ao homem. Contrapôe-se assim, de um lado ao positivismo religioso de mundo criado e oferecido ao deleite, ao esgotamento ou a expiação; e, de outro, ao idealismo intelectualizado no qual, o mundo que se faz do que dele se pensa.

Como objetos centrais dos estudos e, na busca de referenciais mais precisos as Companhias de Dança do Moçambique e as Rodas de Jongo que intencionalmente e apenas para este trabalho, caracterizaram-se respectivamente uma como forma de jogo fechado, isto é, quando um grupo tem dentro de sua organização, um conjunto de normas regimentais e sobre as quais se basearam a permanência e a conservação do grupo; normalmente, tais organizações estão relacionadas a um clã familiar, o que permite a comunicação deste regime, de forma hierárquica através das gerações; e, a outra, como forma de jogo aberta, ou seja, quando não existe necessariamente um grupo estabelecido $e$ as regras dependem de indivíduos que hierarquicamente dominam os saberes, sem os quais não se realizam as rodas; neste caso na comunidade onde vivem, estes indivíduos são distintos por esta sabedoria e, àquela guarda-se o devido respeito. Fazendo-se referência à possíveis processos de humanização dos sujeitos, os mesmos exigem um embasamento histórico, com intuito de estabelecer certa cronologia na existência destas formas, bem como no estudo dos ambientes sócio/culturais em relação com a cotidianidade; em outras palavras, trata-se da organização de formas coletivas com seus reflexos quantitativos e qualitativos, correspondentes a expressividade como produto de trabalho no interior de uma comunidade. Concernente à problemática e ainda correspondente aos mecanismos articulados para a persistência, foi significante verificar, ainda que não especificamente, algumas modalidades de dispositivos organizados, ora com finalidades assistencialistas, ora pertinentes as perspectivas de preservação, mas em muitos casos com sério compromisso com as causas sociais; e ainda, como hoje tem se constatado, o Estado em situação estratégica para a promoção e distribuição de cultura, as captação e distribuição de recursos junto à iniciativa privada e a iniciativa civil-pública; distribuição esta para os mais diversos fins, não justificáveis ou justificados como democratização da cultura. 
No primeiro capítulo, correspondente a APONTAMENTOS TEORICOMETODOLÓGICOS, procuramos amparar nossas reflexões em desenvolvimentos filosóficos e metodológicos, já elaborados, bem como justificar um ponto de partida como a utopia primordial para as investigações científicas.

No segundo capitulo, referente à FESTA - AMBIENTE DA CONVERGÊNCIA, desenvolvemos uma análise deste ambiente, no qual se demonstram reais embates entre hegemonias.

O terceiro capítulo, CONFIGURANDO A RESISTÊNCIA, traz uma reflexão sobre como são mobilizados os valores mediante à ideologia.

No quarto capítulo, CASQUETES, PAIÁS, FITAS, BASTÕES, ANGUÁIAS E TAMBUS, com contribuição mais especificas dos resultados dos trabalhos de campo, tornou-se possível analisar aos equipamentos simbólicos enquanto dispositivos de articulação na expressividade da cultura das classes subalternas. 
This document was created with Win2PDF available at http://www.win2pdf.com.

The unregistered version of Win2PDF is for evaluation or non-commercial use only.

This page will not be added after purchasing Win2PDF. 


\section{CAPÍTULO 1}

\section{APONTAMENTOS TEÓRICO-METODOLÓGICOS.}

\section{1 - Das contribuições filosóficas}

Partimos da convicção de que qualquer pretensão de se propor algum aporte teórico nas áreas das Ciências e Ciências Sociais, nunca poderá fugir a um embasamento filosófico, seja por uma via acadêmica ou pela simples escolha de uma linha de pensamento ou de conduta. Para uma iniciativa em quaisquer destes Campos, esta base para as reflexões são fundamentais, pois funciona antes e acima de tudo como um termo de garantia para sua pertinência histórica. Interessa nesta parte conectar este aporte teórico às muitas reflexões já desenvolvidas, distintas da linha idealista e determinista, introduzindo-o pela alternativa dialética a partir da qual se estabeleceram os nortes para o empenho neste trabalho de pesquisa; tendo, contudo, plena consciência e consideração de que é o objeto, seu auto-movimento, dentro do "movimento da realidade" ${ }^{22}$ que se desenha como o caminho a ser seguido.

\footnotetext{
${ }^{22}$ FERREIRA, Maria Nazareth, Alternativas metodológicas para a produção científica. São Paulo CELACCECA - USP, $2006 \mathrm{p}$.
} 
A ciência compõe os diversos aspectos da atividade humana. $E$, através da ciência o ser humano passou a observar o mundo de maneira mais contundente, para entendê-lo; ela é o caminho por onde procurar explicações e fundamentos, e serve para que ele possa imprimir as transformações que julga necessárias para uma economia constante da vida; "a ciência confere ao homem as faculdades e as capacidades para inquirir, investigar e decifrar os mistérios da Natureza"23. Todavia, as atividades humanas sobre o ambiente, como a agricultura, antes do advento dos números e das letras eram apenas técnicas; a partir daquele momento tem inicio o desenvolvimento científico. Ao longo do desenvolvimento histórico, a partir do positivismo, criam-se o "mito da cientificidade" e o "mito do especialista ${ }^{24}$ que deram origem, como conseqüência, a fragmentação do conhecimento em áreas compartimentadas e distintivas. As abordagens mais especificadas ao objeto de conhecimento e a especialização profissional do pesquisador, mais interessado na dissecação de uma determinada problemática do que em uma transformação social, promovese daí então um concurso livre de produção ou de aquisição de conhecimentos como provisão informacional individualizada. Percebemos mais claramente nos dias de hoje, este tipo de inversão no fluxo de informação disponibilizada pela internet sem critérios de avaliação preliminares, cuja acomodação em "tarefas acadêmicas" pode ser tão fortuita quanto a sua gratuidade. Ou seja, são mínimos os esforços e o tempo dispensado para este tipo de tarefa, o que faz com que redundem em pesquisas cujas finalidades e conteúdos são unicamente quantitativos.

Outra forma de constatarmos o aspecto quantitativo em pesquisas científicas atualmente é quanto a trabalhos para a produção de medicamentos contra os distúrbios causados, por exemplo, pela vida sedentária em grandes centros (depressão, estresses pré e pós-traumáticos, pânico etc.); são evidentemente necessários devido a situações emergenciais, porém quase sempre paliativos quando não se modificam as causas sócio-ambientais destes problemas.

A faina ainda maior por acesso à cultura como erudição amplia um sistema no qual o conhecimento como informação circula retroalimentando e criando um

\footnotetext{
${ }^{23}$ HALL, Stuart. A identidade cultural na pós-modernidade. Rio de Janeiro: DP\&A Editora, 2006, p.26

${ }^{24}$ FERREIRA, Op.cit., p.35
} 
ciclo academicista que gera ininterruptamente a falsa idéia de indivíduos formados para o mercado de trabalho com ampla bagagem cultural. Uma observação simples nos mostra que o saber na maior parte do sistema de ensino básico atual se aplica dividido em doses (de informações); doses de saber entremeadas com práticas sumárias ou quase sempre destacadas de qualquer prática. Assim se idealiza o indivíduo preparado com experiências lógicas unilateralmente mentais, para atuar no mundo de complexidade materiais.

Consideremos, por exemplo, a velocidade com que avançam os desmatamentos e o derretimento das calotas polares. Não é difícil admitir que a criança que inicia hoje sua vida escolar certamente encontrará a vida bem mais transtornada ao final do período de sua educação básica. Há uma preocupação sim com a qualidade (aparelhamento e fluxo de informações atualizadas) do ensino, como há com os produtos oferecidos para consumo. Mas não há preocupação com alguma práxis ao menos alternativa; uma consciência definitiva da unidade entre pensar e agir. Não há ainda preocupação com um contato efetivo entre a classe intelectual, permanecendo esta, como grupo de indivíduos superiores, e os indivíduos, neste sentido considerados inferiores:

Neste contexto, qual é o papel da filosofia? O papel da filosofia é reunir o que está separado, fragmentado, dando um sentido de totalidade e de unidade ao homem e suas ações. Sem a interferência da filosofia, o mundo cognoscível seria um conjunto de forma de parcialidades, onde o conhecimento não teria visibilidade necessária para gerar transformação. ${ }^{25}$

Não se pode deixar de constatar, neste momento em que formação não pressupõe mais a possibilidade de transformação da sociedade, que a busca mais contundente, que hora se encontra é por saídas (saída do permanente estado de crise; não é, porém crise geral, mas, mais que suficiente para colocar mais distante as possibilidades de ordenação: crise econômica, crise da democracia representativa, crise da representação, crise das identidades étnicas e culturais, crises sociais, crise ecológico-ambiental, crise ética-moral, crise populacional, crise política, crise dos intelectuais, crise de autoridade etc.)

${ }^{25}$ Id., p.35. 
- saídas para o conflito (jargão jornalístico): "Mas o conflito é a rebelião das sadias aspirações humanas contra o conformismo: é uma insurreição moral, consciente ou inconsciente. (É evidente que isso não pode ser dito de todo e qualquer conflito)." ${ }^{26}$

A verdade é que não sabemos se queremos sair. Ou talvez, precisemos permanecer no mínimo, o tempo de dialogar com o lugar. Os sistemas de divisão social do trabalho, de divisão centro-periferia, dos conflitos armados e a migração por melhores condições de vida e trabalho, são exemplos de um deslocamento que se impõe. Se considerarmos as saídas possíveis, consideraremos o deslocamento como necessário; a contradição está em ser o deslocamento a manifestação de um desejo intrínseco; produção e a autoreprodução opostas às pré-determinações metafísicas.

O cientificismo cuidou para que muitas pesquisas e orientações não passassem de preciosidades teóricas. Outros trabalhos servirão, quem sabe, de base para pensamentos e comportamentos socialmente previsíveis, como por exemplo, a mudança de hábitos alimentares mediante um quadro de alerta sobre problemas causados por obesidade, sobre a possibilidade da escassez de alimento e de água potável. Porém é preciso colocar em prática os planos de construção de um almejado mundo melhor possível.

Dentre tantas reflexões e teorias já produzidas nos cabe seguir o caminho indicado por aqueles que anunciam a filosofia da práxis como alternativa científica de estudo e compreensão desta ação construtiva, considerando-se as totalidades humanas (perceber, conceber, representar e transformar a realidade). Por que a filosofia da práxis? A resposta a esta pergunta pode ser obtida pelo que Antonio Gramsci ${ }^{27}$ (1966) aponta como sendo desta filosofia "duas tarefas: combater as ideologias modernas em sua forma mais refinada, a fim de poder constituir o próprio grupo de intelectuais, e educar as massas

\footnotetext{
${ }^{26}$ HELLER, Agnes. O cotidiano e a história. São Paulo: Editora Paz e Terra, 2004, p. 96

${ }^{27}$ GRAMSa, Antonio. Concepção Dialética da História - Tradução de Carlos Nelson Coutinho - Ro de Janeiro 1966. Ed. Givilização Brasileira SA. pp.01-02 - A complementação desta nota sobre a trajetória política de Antonio Gramsci encontra-se em anexo.
} 
populares, cuja cultura é medieval”28. Não há qualquer indício de anacronismo, ao se evocar a filosofia clássica alemão, e o período medieval uma vez que ao se falar de massas populares há completa atualidade ao que se refere às condições. Podemos dizer que desde a concepção de cultura moderna, estabelece-se maior enfoque da cultura como área de conhecimento, como também definem-se os caminhos para a aculturação da sociedade, onde está pré-estabelecido como e em que nível participar; contrária portanto a concepção de cultura própria da sociedade - a sociedade da cultura. Tarefas são ações, não somente medidas, nem tão somente as metas, o conjunto de todas elas, mais a teoria cujo papel é "produzir um contra-discurso que revele as contradições internas da ideologia" ${ }^{29}$ Conforme assegura a estudiosa do método dialético, Maria Nazareth Ferreira (2006) e também defensora do pensamento gramsciano, a teoria "está encarregada de desvendar os processos reais e históricos que originam a dominação de uma classe sobre a outra, enquanto a ideologia visa exatamente o contrário, a dissimulação dessa diferença."30

Quando abordamos aos disparates da globalização como efeito do (neo)liberalismo, e nos referimos, dentro do sistema de divisão da sociedade por classes, e em especial a uma classe que por aquela dissimulação permanece subalternizada, (entendemos por esta forma que haja sim um processo contínuo de geração desta condição), percebemos que, - como já afirmado pela pesquisadora das Ciências Sociais Maria Nazareth Ferreira (1997) a partir das proposições de Garcia Canclini (1988):

Os intelectuais que mais escreveram sobre o assunto (a cultura subalterna e a comunicação popular como projeto alternativo), geralmente realizaram pouco ou nenhum trabalho empírico; a

\footnotetext{
${ }^{28}$ Ibid., p. 104. "Esta segunda tarefa, que era fundamental, graças ao caráter da nova filosofia, absorveu todas as forças não apenas quantitativamente, mas também qualitativamente; por razões "didáticas", a nova filosofia se combinou com uma forma de cultura que era um pouco superior à média popular (que era muito baixa), mas absolutamente inadequada para combater as ideologias das classes cultas, ao passo que a nova filosofia nascera precisamente para superar a mais alta manifestação cultural da época a filosofia clássica alemã, e para criar um grupo de intelectuais próprios do novo grupo social ao qual pertencia a concepção do mundo."

${ }^{29}$ FERREIRA, Op. cit., p. 69

${ }^{30}$ Ibid., pp. 69-70.
} 
pesquisa social, na maioria dos casos se restringe ao econômico e ao político ${ }^{31}$

Como uma alternativa de investigação resta tomar como ponto de partida a dimensão das subjetividades até aqui, pelo que podemos constatar calcula-se como simples atributo da cotidianidade. Em nosso entendimento a capacidade de subjetivação se inscreve como faculdade onde o conceito de valor é elevado a nível incomensurável do Valor objetivo, como nos apresenta Heller (2004). "Consideramos valor objetivo, ou seja, independente da avaliação humana, o conjunto de todas as relações, produtos, ações, idéias etc. sociais que promovem o desenvolvimento da essência humana no estágio histórico tomado em consideração." 32

Acrescentamos a este pensamento o que Giovanni Semeraro (2006) ${ }^{33}$ assim escreve em sua obra Gramsci e os Novos Embates da Filosofia da Práxis:

Toda ciência está vinculada às necessidades, à vida, à atividade do homem. Sem atividade do homem, criador de todos os valores, inclusive científicos, o que seria a "objetividade"? Para Gramsci não existe objetividade absoluta, como se houvesse "um ponto de vista cósmico", mas esta é sempre "humanamente objetiva", é uma objetividade histórica, capaz de alcançar um "universal objetivo", "subjetivamente" definido. ${ }^{34}$

O conceito de sociedade civil proposto por Antonio Gramsci (1975), apresentado por este mesmo autor, justifica ainda mais a indicação deste ponto de partida, quando representa o lugar "onde se manifesta a livre iniciativa dos cidadãos, seus interesses, suas organizações, sua cultura e valores e, aonde, praticamente, se estabelecem as bases do consenso e da hegemonia. ${ }^{\text {"35 }}$

Outro conceito trazido a baila por Gramsci (1966) é o de classe subalterna a partir dos estudos de Marx e Engels. Estes pensadores,

[...] formularam seu pensamento a partir da realidade social por eles observada: de um lado, o avanço técnico, o aumento do

\footnotetext{
${ }^{31}$ CANCLINI, (1988) apud FERREIRA (1997), p. 40

${ }^{32}$ HELLER, Op. cit., p. 78

${ }^{33}$ SEMERARO, Giovanni. Gramsci e os novos embates da filosofia da práxis. Aparecida, SP: Idéias \& Letras, 2006, 199p

${ }^{34}$ GRAMSCl, (1975) apud SEMERARO, (2006), p.27

${ }^{35}$ SEMERARO, Op. cit., pp. 95-96
} 
poder do homem sobre a natureza, o enriquecimento e o progresso; de outro e contraditoriamente a escravização dos trabalhadores, cada vez mais empobrecidos, a miséria, a exploração e o sofrimento do proletariado. ${ }^{36}$

Tal distinção também se apresenta como resultado ainda daquela fragmentação do saber acima mencionada. Neste ponto, para melhor referenciar nosso objeto de estudo, interessa acrescentar que:

Gramsci parte dos conceitos elitistas que definem cultura como saber enciclopédico, atividade especulativa reservada aos grandes talentos e circunscrita ao campo artístico e educativo. A partir daí, constrói um conceito dinâmico e historicista, no qual a cultura é compreendida como um processo que se conserva e renova-se permanentemente somente na prática social. Está ótica amplia o sujeito produtor/receptor/consumidor de cultura a todo o universo social. ${ }^{37}$

E continuando:

Por outro lado, aponta a necessidade da superação de um estado de cultura existente para um dever ser cultural, tipificando os processos culturais como cenários de confrontação de classe, onde se constrói, preserva-se ou destrói-se o consenso. Estes cenários de confrontação são lugares do povo, aqui definido, a partir de categorias de classe, como o conjunto de classes subalternas e instrumentais que existem em todos os tipos de sociedades atuais. Esta definição de classes subalternas apresenta diferenças significativas com o de classes exploradas, na medida em que o subalterno está num campo semântico que transcende a determinação econômica pelo lugar que a classe ocupa na estrutura produtiva, atendendo ao mesmo tempo, à dominação cultural, a qual se define pelo lugar que a mesma classe ocupa no âmbito da hegemonia [...]. ${ }^{38}$

Vale enfatizar que tais conceituações projetadas ao contexto atual indicam que há um contínuo processo de geração também de uma cultura que tem sido confundido com a das classes subalternas; quando nos detemos, por alguns momentos sobre as cifras movimentadas entre ricos, esta simulação tem colaborado para o aumento da distância em ralação aos pobres, ao mesmo tempo aumentando a pobreza em escala global pela prática das mídias de

\footnotetext{
${ }^{36}$ FERREIRA, Op. cit., p. 55

${ }^{37}$ MADRIZ, (1989) apud FERREIRA (1997), p. 29

${ }^{38}$ Id., p. 29
} 
homogeneização do pensamento. Como instrumento de expansão do sistema neoliberal, quando não se trata do exótico, exclui o diferente. Quando nos propomos a uma tentativa de transformação deste quadro, fazêmo-lo pelo desconforto relativo ao conformismo que paira sobre o comportamento humano. Unimo-nos à crítica arguta e histórica, porém conscientes de que nunca poderá ser sem partirmos de um embasamento filosófico. O papel da filosofia deve ser o de estabelecer o elo entre aqueles saberes particularizados e as possibilidades de articulação dos menos favorecidos das sociedades frente ao caos.

Quando tratamos de cultura popular subalterna é necessário deixarmos claro que em boa parte do tempo estamos lidando com experiências práticas, com atividades cotidianas que em maior proporção são destituídas de comprovações científicas, são apenas atividades, concretudes. Também não se tratam de observações esquemáticas para posterior prescrição de um sem número de descrições, destacadas de algum ponto da história e sua reprodução proposta como alternativa para qualidade de vida. Isto não somente exemplificaria empirismo como também repete uma prática na qual as singularidades servem de conteúdo midiático ou para consumo imediato. Por isto mesmo, esta proposta não deve escapar a uma reflexão filosófica preliminar no sentido de garantir de que se trata de um estudo sobre "um concreto pensado" ${ }^{39}$, ou seja, não se trata evidentemente de se reduzir as observações à dados empíricos, uma vez que abordamos a uma atividade material humana, mas que seu fundo está em um campo subjetivo e como objeto de conhecimento refere-se "ao concreto como síntese de múltiplas determinações, como unidade do diverso, como síntese do resultado, ponto de partida da intuição, da representação, [...]."40

Quando ensejamos este alicerce filosófico, temos em consideração o que possa representar a "relação de conjunto com a totalidade" ${ }^{41}$. Neste sentido totalidade que serve de pano de fundo destas atividades as quais aqui nos referimos (as manifestações expressivas próprias e típicas de sociedades que

\footnotetext{
${ }^{39}$ Id., Op. cit., p. 103

${ }^{40}$ MARX, 1971 apud FERREIRA, 2006, p. 101

${ }^{41}$ FERREIRA, Op. cit., p. 25
} 
conservam na história e no tempo os modos mais primitivos e por isso mais autênticos) é "o mundo do trabalho" como fator essencial a socialização, a capacidade de construir coletivamente e de modo cooperativo, e que aqui justifica o sentido de unidade entre conhecer e agir. De modo que se revolvam postulações sedimentadas, haveremos de confrontar a hegemonia dominante com um simples modo de agir que subsiste aos processos de modernização, principalmente no que corresponde à comunicação social enquanto mecanismo de interação e veículo do discurso entre as classes sociais. E, é a partir da ética, nas diversas esferas (política, econômica, cultural) que caberá a crítica ao que se considera como idealismo transcendental das ações humanas e a ideologia empregada em formas de dominação na sociedade. O que buscamos sempre é a verdade sobre os processos de apropriação escamoteada por todas as formas e aparências pelas quais se traveste o capitalismo global; partimos para uma observação dos momentos de explicitação da humanidade, conforme o pensamento de Agnes Heller (2004). Adentramos o terreno das relações de produção dissolvidas no contexto do trabalho alienado. $O$ trabalho institui o senso da propriedade. A apropriação é mãe da técnica, dos instrumentos e das ferramentas. Quando chamamos um especialista para que concerte o telhado de nossa casa, na verdade estamos lhe permitindo que coloque em ação seu senso de propriedade.

Nosso ponto de partida é a consideração ao homem elevado a categoria do ser "humano-genérico", ${ }^{42}$ e, a maior dose concentração caberá, a título de referenciar o estudo, naquilo que se nos apresentar como distintivo do homem como ser dotado de consciência e razão, isto é, sua capacidade de transformações concretas a partir do que se consubstancia em representações objetivas diferenciadas das ações instintivas correspondentes a meros reflexos. Chamamos de reflexo todo comportamento decorrente, ou seja, não objetivo, não construtivo, apenas reprodução mecânica de arquétipos veiculados pelas mídias ou pelas instituições encarregadas da ordenação social do Estado.

\footnotetext{
${ }^{42}$ HELLER, Op. cit., p.21 - "[...] o genérico está 'contido' em todo homem e, mais precisamente em toda atividade que tenha caráter genérico, embora seus motivos sejam particulares. Assim, por exemplo, o trabalho tem freqüentemente motivações particulares, mas a atividade do trabalho - quando se trata de trabalho efetivo (isto é, socialmente necessário) - é sempre atividade do gênero humano. Também é possível considerar como humano-genéricos em sua maioria, os sentimentos e as paixões, pois sua existência e seu conteúdo podem ser úteis para expressar a substância humana."
} 
(escola, quartéis, família, Igreja etc.) como, por exemplo, a banalização da violência, a banalização do gosto, banalização das identidades etc.

É a partir de suas procuras, muito mais do que por sua existência que focamos a idéia de deslocamento. Este deslocamento pressupõe uma possibilidade de caminho a percorrer - o método. Dentro desta possibilidade visamos diagnosticar, proposições filosóficas que confirmem e situe o homem na condição de sujeito e objeto de sua própria história. Condutor e conduzido. Antes, porém algumas distinções importantes a respeito deste deslocamento devem ser apresentadas que, entretanto não se isolam nem se desconectam, pois ambas estão em referência ao sujeito. Uma delas, apresentada por Maria Luiza M. Mendonça (1997), propõe

[...] deslocar o eixo das análises sobre a produção cultural de seus formatos e conteúdos para entender os processos e o papel que nele desempenha o receptor ou consumidor de cultura; é forçoso e necessário operar com uma concepção de cultura e de produção cultural que permita encontrar um lugar para a existência de sujeitos. Esse deslocamento [grifo nosso] tem um peso político importante, pois só assim se pode admitir a existência de projetos de conquistas sociais, de lutas por democracia, por participação, por igualdade, por direitos. ${ }^{43}$

Neste postulado encontramos respaldada uma idéia de alternância do ponto de referência para identificação da objetividade da ação do(s) sujeito(s), visto que muitas abordagens solidificam esta ação em uma visão unilateral que impede uma concepção de amplitude das ações e da criatividade. Neste entendimento ou o sujeito é o da resistência contra uma determinada ordem ou é o sujeito da própria ordem - sujeito-replicante. Consideramos a subsistência de um sujeito que transita e se articula (articulação é um termo que não compõe com alguma freqüência os objetivos formativos da educação atual, que se baseiam ainda na identidade cultural nacional e no mercado/concorrência de trabalho e que conhecimento em doses dota o aluno de preparo para a vida. Não se faz de maneira efetiva uma leitura constante do ambiente das sociedades e de como nos comportamos neste mundo das coisas, muito menos procuramos atribuir a

\footnotetext{
${ }^{43}$ MENDONÇA, Maria Luiza M. de. Cultura Subalterna e Neoliberalismo: a encruzilhada da América. Latina, Maria Nazareth Ferreira (Org.). São Paulo: CELACC:ECA/USP, 1997, p. 56
} 
alguém, neste caso os estudantes, as responsabilidades por um sistema de vida sustentável, ou seja, o conhecimento passa ao largo das possibilidades de apropriação. Somente o senso de propriedade, restaura a responsabilidade e habilita a faculdade da articulação no indivíduo. Quem faz, conhece) entre estas duas esferas (ou até mesmo fora delas), com suas próprias produções alternativas. Não somente como um observador externo que interpreta o mundo, mas que na busca de suas bases existenciais não perde o senso de propriedade sobre a realidade concreta. Caso tenhamos que admitir esta perda será nossa tarefa restituí-la.

Outra análise de deslocamento é apresentada por Stuart Hall (2006). O autor observa do ponto de vista das mudanças que, como efeito, está provocando um deslocamento das "estruturas e processos centrais das sociedades modernas e abalando os quadros de referência que davam aos indivíduos uma ancoragem estável no mundo social," apontado também pelo autor como fragmentação das "paisagens culturais de classe, gênero, sexualidade, etnia raça e nacionalidade" e tem como reflexo direto como "deslocamento ou descentração do sujeito". Para melhor sintonizarmos nossa abordagem sobre o sujeito e este quadro de deslocamento ou descentração podemos acompanhar a reflexão que este autor faz progressivamente distinguindo primeiramente um

[...] sujeito do Iluminismo [...] baseado numa concepção da pessoa humana como um indivíduo totalmente centrado, unificado, dotado das capacidades de razão e de consciência e de ação cujo "centro" consistia num núcleo interior, que emergia pela primeira vez quando o sujeito nascia [...]. O centro essencial do eu era a identidade de uma pessoa. $[\ldots]^{44}$

Em seguida uma

[...] noção de sujeito sociológico refletia a crescente complexidade do mundo moderno e a consciência de que este núcleo interior do sujeito não era autônomo e auto-suficiente, mas era formado na relação com "outras pessoas importantes para ele", que mediavam para o sujeito os valores, sentidos e símbolos - a cultura - dos mundos que ele/ela habitava. [...] a identidade, nessa concepção sociológica, preenche espaço entre

\footnotetext{
${ }^{44}$ HALL, Op. cit., p. 09, passim
} 
o "interior" e o "exterior" - entre o mundo pessoal e o mundo publico. ${ }^{45}$

Destacamos até aqui dentro desta linha evolutiva da análise do autor na constituição histórica do sujeito como sujeito sociológico, o aspecto metodológico como ponto referencial na seguinte reflexão. "A identidade então, costura (ou, para usar uma metáfora médica, 'sutura'), o sujeito à estrutura. Estabiliza tanto os sujeitos quanto os mundos culturais que eles habitam, tornando ambos reciprocamente mais unificados e predizíveis. ${ }^{\text {"46 }}$

Se estamos argumentando a respeito de deslocamento, temos que admitir que esta estabilidade jamais poderia permanecer como tal e certamente adotaria, a posteriori uma orientação, o liberalismo e, na sua versão atualizada, o neoliberalismo. Entretanto a questão mais preponderante é a rapidez efusiva do fluxo das mudanças que não nos deixa margem para conciliar uma acepção de sujeito e identidade como se constata na concepção do (sujeito) pósmoderno;

[...] como não tendo uma identidade fixa, essencial ou permanente. A identidade torna-se uma "celebração móvel": formada e transformada continuamente em relação às formas pelas quais somos representados ou interpelados nos sistemas culturais que nos rodeiam (Hall, 1987). É definida historicamente, e não biologicamente. $\mathrm{O}$ sujeito assume identidades diferentes em diferentes momentos, identidades que não são unificadas ao redor de um "eu" coerente. Dentro de nós há identidades contraditórias, empurrando em diferentes direções, de tal modo que nossas identificações estão sendo continuamente deslocadas [grifo nosso]. ${ }^{47}$

Ainda que como noções simplificadas, como alerta o próprio autor, e aqui ainda mais sintetizadas, não é sem razão que transcrevemos estas passagens, pois devemos ter em mente ou em questão, de que (qual) sujeito estamos tratando? Podendo ser, este sujeito, um complexo de identidades fugidias, ainda que dotado de consciência e razão, encontrar ou mesmo sugerir plena constituição para ele não será uma tarefa das mais simples.

\footnotetext{
${ }^{45}$ Ibid., pp. 07-09, passim

${ }^{46}$ lbid., p. 12

${ }^{47}$ lbid., p. 11-13
} 
Esta tentativa da constituição ideal do sujeito, bem como da relação sujeito objeto já era matéria da filosofia clássica alemã, porém nunca será demasiado iluminar filosoficamente uma das mais importantes decorrências desta relação. Façamos, porém duas ressalvas antes de adentrarmos a análise de um processo de intensificação da alienação. Em primeiro lugar não se trata de dar continuidade aos riscos da simples troca de mãos sobre o poder, a simples troca de posição entre dominantes e dominados, pois a história nos mostra que quase sempre quem assume o comando muitas vezes só faz replicar a fórmula já aplicada pelo regime deposto. Em segundo lugar a idéia de "uma política de reconhecimento" terá sentido se devolvida juntamente com uma "justiça distributiva" ${ }^{48}$ projetadas à problemática da justiça social, como analisa Zygmunt Bauman (2003), para elevação a uma unidade e não mero reconhecimento para que conste de autos dos registros históricos.

Os estudos de Hegel não nos conduzem à superação das especulações idealistas de modo objetivo, certamente. Não vamos além do, numa palavra, solipsismo, como muito já tem se repetido. Mas, considerando suas reflexões sobre o fenômeno da coisidade, onde senhor e escravo são figuras interdependentes, seria uma visão simplista admitir que em um sistema de dominação, ambas as figuras, dominantes e dominados, não sejam figuras igualmente interdependentes. Há complementaridade elementar na arte, por exemplo, como na relação entre indivíduos, inclusive tendo aquela como meio. Porém, neste ultimo caso, aquele que assume o poder sobre o outro, o detém ou por uma ordem hierárquica, classista, oportunista ou ainda como prêmio ao conquistador, pois que nesta reciprocidade o reconhecer, ou esta interdependência entre ambas as consciências projetadas uma a partir de outra, e logo em uma única consciência de si mesma, resulta em certa paralisia que podemos chamar uma paralisia da individuação, gerada por um dualismo aparente apenas, que não se aprofunda ao âmago das partes para evidenciar a totalidade concreta (a unidade). O materialismo histórico através do método

\footnotetext{
${ }^{48}$ BAUMAN, Op. cit., p. 73, passim. "[...] Se, porém forem devolvidas à problemática da justiça social que lhes corresponde, as reivindicações ao reconhecimento e a política de esforços de reconhecimento se tornam um terreno fértil para o comprometimento mútuo e o diálogo significativo, que poderão eventualmente levar a uma nova unidade - em verdade, uma ampliação e não um estreitamento do âmbito da comunidade ética. [...] A mescla de justiça distributiva com uma política de reconhecimento é, pode-se dizer, uma conseqüência natural da moderna promessa de justiça social [...]".
} 
dialético propõe um movimento a partir de um dualismo real e contraditório, onde a oposição ou negação desencadeia o deslocamento positivo; vale ressaltar que, como base teórica, interessa das reflexões do pensador alemão, a experiência da consciência, pois é nas marcas indeléveis impressas nesta consciência que vale a pena mergulhar e apreender do conhecimento gerado da fórmula identificação/apropriação. Não importa permanecer à superfície flutuando sobre impressões de um estado de coisa. Todavia, buscamos a contrapartida, buscamos respostas. Não somente para um sistema de superposição ou liderança ou ainda de subordinação correspondentes à ordem capitalista e liberal em que subalternidade corresponda à força inerte ou inoperância. Bauman (2003) dimensiona tal inoperância como um "[...] mero depósito (daqueles para os quais) a sociedade circundante não faz uso econômico ou político." 49 De outra forma que passaremos a vida resistindo. Mediante esta premissa, se tomarmos, por exemplo, uma estatueta de adoração. Ou algo que já tivera estabelecido seu valor em uma esfera supostamente lúdica e de teor mágico ou sagrado e, dentro desta mesma esfera de valor se transfigurasse para um significante produto de mercado para consumo direcionado. Supondo-se que dentro do âmbito religioso, um determinado interesse seja formado e instruído para aquela forma de consumo através da condução comunicacional (as mídias daquela esfera). Se se considera que aquele objeto de desejo é um meio de exposição da vulnerabilidade interior do sujeito de forma multilateral (pelo poder da aquisição, como diferencial classista, pela devoção, pelo desejo e posse etc.), podemos admitir que este mesmo objeto também corrobore para a consolidação dos pressupostos para a edificação de um estado de sujeição: o sujeito dominado, seduzido pelo objeto/produto.

Um aspecto importante a ser ressaltado é a criação do excedente na produção (de objetos/produtos), seja material ou força de trabalho ou as subjetividades que na abordagem de Hegel se identificam, na relação entre senhor e escravo como consciência inessencial ou o agir inessencial desta consciência ${ }^{50}$, tomada do ponto de vista do senhor para o escravo. Mas, por mais simplista que possa

\footnotetext{
${ }^{49}$ WACQUANT, 1993 apud BAUMAN, 2003, p.108

${ }^{50}$ HEGEL , Georg Wilhelm. Fenomenologia do espírito. Petrópolis, RJ: Vozes: Bragança Paulista: USF, 2002, p.148
} 
parecer a aplicação destas reflexões, não devemos desconsiderar o movimento involuntário em busca desta dada negação. Ou seja, a negação do essencial em qualquer uma das partes e em ambas simultaneamente. Mesmo nesta interdependência, ao se alcançar de forma absoluta esta negação outra relação se estabelece, uma nova procura por sentido e significação de auto-afirmação; mesmo não saindo de um ciclo vicioso. Procuramos avidamente vislumbrar uma possibilidade de experimentar pontos de equilíbrio mais premente que um simples aniquilamento; seja das forças positivas ou das forças negativas" ${ }^{51}$. Vale lembras que estamos analisando o que pode ser exatamente a origem desta espécie de falência ou de um apagamento do sujeito em função de uma sublimação do objeto e que assim permanece. Observemos figurativamente como exemplo oposto ao apresentado acima, os mutirões com seus cantos de trabalho, ou então da festa (dos povos originários), que se realizam pela comida produzida ou conquistada no esforço da caça e depois redistribuída entre todos os membros da comunidade. Extraímos dos estudos da pesquisadora Betty Mindlin (2006) uma passagem bastante significativa:

[...] Assim como há cantos de trabalho, pesca caça e guerra, para invocar a ajuda dos espíritos, em tudo o que se relaciona à produção material, também a arte é produtiva e entrelaçada ás atividades que rendem comida, combatem a necessidade. ${ }^{52}$

Verificamos que a atividade cotidiana de manutenção da vida está completamente vinculada com princípios metafísicos e imaginários, entretanto a não há quem, em qualquer posição esteja imune a necessidade no reconhecimento da comunidade. Continuando, Mindlin (2006) apresenta uma idéia da possibilidade de uma vida sem capitalismo no regime da aldeia:

Marx ficaria encantado se visse o mesmo que eu: pois a oposição entre o reino da necessidade e o da liberdade, como domínios independentes, é uma característica do capitalismo, inexistente na aldeia. [...] Se a terra é do povo, a propriedade dos objetos de uso ou dos instrumentos de produção é sempre claramente delimitada. Há um enorme respeito à esfera de cada um, ao que é de outras pessoas. [...] Se alguém traz comida para dar a uma casa é muito importante que saiba dar a cada um, não deixando ninguém de fora. [...] A estranha mistura do

\footnotetext{
${ }^{51}$ Ibid., p. 149 "[...] Assim, o senhor não está certo do ser-para-si como verdade; mas sua verdade é de fato a consciência inessencial e o agir inessencial dessa consciência. [...]"

${ }^{52}$ MINDLIN, Betty Diários da Floresta. São Paulo: Terceiro Nome, 2006.p.95
} 
comunitário e do individual confunde quem espera encontrar formas coletivas de produção e consumo. ${ }^{53}$

Podemos perceber claramente que há orientação vem da medida do convívio um observa o outro; e, se assim podemos interpretar, menos freqüentemente arbitrariedade. Na conclusão desta passagem, há uma questão que não se equaliza no atual sistema de mercado globalizado cujo resultado tem sido a elevação do grau de individualização nas sociedades.

[...]. O que faz de um povo uma comunidade? A análise antropológica enfatiza dois pólos característicos da sociedade indígena, o domestico e o comunitário. A economia indígena poderia ser vista como um conjunto de unidades de produção doméstica relativamente autárquicas - as ocas, por exemplo -, compostas por famílias extensas que se apropriam dos meios de produção e distribuem o produto. Mas, essas unidades não se reproduziriam se não fosse sua organização no todo maior que é a comunidade. $[\ldots]^{54}$

Complementando esta observação a respeito de um sistema comunitário colocamos como uma indagação o raciocínio compartilhado por Bauman (2003) e Hall (2006) de que na sociedade moderna tardia, vivendo nas cidades a comunidade não é mais que imaginada ${ }^{55}$.

Voltando a análise do inessencial para que se sustente a identidade do senhor na relação de dominação, cabe, portanto correlacionar a transição de algo classificado com valor intrínseco, valor próprio ou valor de uso para o outro valor, o valor de troca. Ao estabelecermos certa correspondência entre uma relação de dominação (sujeito/objeto) e uma produção excedente (inessencial), também se esclarece aquilo que nesta relação toma o status de mercadoria; Georg Lukács (2003) em seus estudos sobre a dialética marxista bem nos esclarece dos aspectos fetichistas da mercadoria. Observados tais aspectos se pode então, constatar um mapa do caminho percorrido pelo homem, até se tornar subproduto de seu próprio conhecimento e reificado, como conseqüência inevitável do desenvolvimento tecnológico. Não condenamos o desenvolvimento tecnológico. Exceto quando implicado na produção do

\footnotetext{
53 Ibid., p. 95, passim

${ }^{54}$ lbid., p. 96

${ }^{55}$ BAUMAN, Op. cit., p. 09
} 
excesso $^{56}$. Inicialmente, este caráter de fetiche, como forma de objetividade atribuída à mercadoria é próprio do sistema capitalista moderno relacionado também ao sujeito submetido a este sistema, o que equivale a uma mudança de comportamento da sociedade de forma qualitativamente diferente. A mercadoria se sinaliza como um problema central e estrutural na sociedade capitalista e, toda objetividade relativa ao relacionamento mercantil, terá sua correspondência em subjetividade na sociedade (burguesa). Lukács (2003), aludindo a análise de Marx sobre a mercadoria em uma sociedade primitiva, afirma que "a troca direta representava mais a transformação inicial dos valores de uso em mercadorias do que a transformação da mercadoria em dinheiro. ${ }^{.57}$ Assim continua, porém o dinheiro se expressa em vantagens cada vez menos justificáveis coletivamente.

O dinheiro ao longo dos anos mudou apenas em sua substância, justamente para fluir em paralelo com a comunicação, em termos numerais são infinitas e sempre surpreendentes as cifras; haja vista que os valores monetários liberados pelos governos das nações mais ricas em socorro as instituições financeiras e empresas transnacionais na atual crise do sistema monetário mundial. De fato demoramos um pouco até darmos conta de qual esfera está sendo atingida pela voracidade capital que transforma recônditas subjetividades em produto. Hardt e Negri (2005) reafirmam esta visão analisando a transformação da cena contemporânea pela hegemonia do trabalho imaterial:

Quando nossas idéias e nossos afetos, nossas emoções, são postos para trabalhar, por exemplo, sujeitando-se assim, de uma maneira, às ordens do patrão, freqüentemente vivemos novas e intensas formas de violação ou alienação. ${ }^{58}$

De fato é o que podemos constatar cada vez que formas de afetividade são oferecidas de maneira obtusa ou explícitas; embutidas ou apropriadamente, mas como serviços, como produto (uma família feliz à mesa na propaganda de margarina). "O valor de troca está ligado ao valor de uso, mas não é somente por exceder a quantidade necessária ao consumo local que os valores de uso

\footnotetext{
${ }^{56}$ Ibid., p. 113

${ }^{57}$ LUKÁCS,Georg, História e Consciência de Classe. São Paulo: Martins Fonte, 2003, p. 197.

${ }^{58}$ HARDT; NEGRI, Op. cit., p. 100
} 
deixam de ser o que são para tornarem-se meios de troca, ou seja, mercadorias. ${ }^{59}$

É também porque o capitalismo anula ou ofusca conseqüentemente este valor de uso. Primeiramente, conforme o pensamento de Marx, na troca mantinha-se para ambas as partes o valor de uso, pois correspondia antes de qualquer coisa a uma demanda e não a um excedente criado para o lucro e para a mais valia. E, somente se tornam mercadorias dentro dos limites do valor de uso imediato, isto é, visando à necessidade, através, inclusive da monopolização de certas produções.

Podemos afirmar que hoje a demanda por satisfação provoca um sistema de produção excedível, que nunca atinge um patamar de suficiência. E, a monopolização é, por outro lado facilmente comprovável com a produção, por exemplo, de frutas sem sementes e de outras plantas que não se reproduzem exceto em laboratório, o que obriga ao pequeno e médio produtor adquirirem as sementes de uma única empresa que detém aquela patente.

Outra análise que nos interessa também nestas reflexões é o fato de que, este processo de troca não aparece originalmente no interior das comunidades, mas sim nos pontos de contatos fronteiriços, e, ao atingir o interior de uma comunidade, aí sim, "atua de maneira desagregadora provocando mudanças qualitativas nas manifestações vitais daquela sociedade, em função da dominação da mercadoria."

Entendemos por este postulado que há inicialmente um movimento do interior para o exterior e posteriormente um movimento inverso chegando a potencializar cada indivíduo como consumidor. Outro importante ponto a se destacar do pensamento de Lukács (2003), é o de que o problema da mercadoria é especificamente um problema estrutural da sociedade capitalista moderna em contraposição a estruturação de uma sociedade primitiva onde se evidenciava uma forma de dominação das condições de produção sobre os produtores; pelas relações de dominação e servidão os que não têm recursos próprios servem aos que têm, tendo, troca da garantida de subsistência. $\mathrm{Na}$

\footnotetext{
${ }^{59}$ LUKÁCS, Op. cit., p. 195.
}

${ }^{60}$ lbid., p. 196. 
sociedade moderna o que pre-domina é o desejo (do senhor) sobre o (desejo do) escravo; vai além do lucro, às estâncias das subjetividades. Esta metamorfose na esfera da valoração preconiza e estabelece a situação onde o trabalhador se torna livre para vender sua força de trabalho. Este trabalho como mercadoria transforma a relação entre dominador e dominados, pois a interdependência, na aparência, se desfaz uma vez que deixa de existir o reconhecimento e a reciprocidade. Não se trata evidentemente de dizer que uma situação de dominação entre senhor e escravo seria melhor que outra situação de dominação pela mercadoria, mudando apenas os agentes e permanecendo o sistema de domínio. Mas, que nesta ultima forma de dominação prevalece e, é sempre crescente a contingência de degradação. Pois, o que deixa de existir é a substância mediadora, a qual Hegel identifica como consciência de si. Nós a chamaremos de subjetividades edificantes. Consideramos, contudo, que os subjetivismos puramente correspondam, como outras tendências, doutrinas e orientações separadamente, a marcos notórios de nossos (humanidade), ensaios e erros.

O homem cuja consciência está submetida às formas nas quais a reificação se exprime, é confrontado com seu próprio trabalho como algo objetivo, independente dele e que o domina por leis próprias que são organizadas segundo um similar princípio de cálculo - relações e transformações quantitativas.

Prosseguindo com o raciocínio de Lukács (2003), convém igualmente destacar a contradição entre os extremos das esferas da subjetivação e da objetivação ${ }^{61}$, condicionando uma concepção abstrata do trabalho humano e objetivando-o em mercadoria; de forma objetiva a mercantilização torna-se possível mediante a igualdade e permutabilidade de objetos qualitativamente diferentes, em decorrência exatamente desta abstração do trabalho humano; subjetivamente, o trabalho humano funciona como denominador referente ao qual, os objetos são multi-replicados e seu valor é sempre reduzido na equação mercantil; o valor independe da inferência humana. $O$ trabalho humano é também princípio na ordem da produção de mercadorias; somam-se a esta contradição, às leis

\footnotetext{
${ }^{61}$ lbid., p.201.
} 
próprias desta ordem que são estranhas à consciência humana (tempo é dinheiro - cultura é lucro), tem-se daí como resultado a racionalização. Segundo Lukács (2003), esta operação "configura uma eliminação, cada vez maior das propriedades qualitativas humanas e individuais do trabalhador." Elencamos a seguir, a partir destas reflexões, se constatam numa série de fatores que compõem ou configuram este sistema racionalizado, a saber, 0 trabalho fragmentado; as operações parciais abstratamente racionais; 0 rompimento da relação entre trabalhador e o produto de seu trabalho; a repetição mecânica; a intensificação do período do trabalho; o cálculo racional - o tempo médio e empírico para figurar quantidade objetivamente calculável e a separação das qualidades psicológicas do conjunto da personalidade como forma de objetivação. ${ }^{62}$

José de Souza Martins (1994) elabora a respeito destas características do processo de racionalização do trabalho, mediante o aspecto tecnológico, uma interessante figura em forma de narrativa, sobre uma "aparição do demônio na fabrica" enfatizando tenazmente o impacto das transformações advindas da implantação de modernizações tanto de equipamentos quanto de novas cadências nos expedientes de trabalho ${ }^{63}$.

Representam aqueles fatores, algumas perspectivas para uma observação crítica do processo de fragmentação do sujeito, demonstrado agora na relação sobre o valor de uso de caráter inteiramente heterogêneo (objetivo e subjetivo). Assim como aquela contradição resulta na racionalização da produção, também o valor de uso dos objetos, é determinado especificamente de acordo com a criação de demanda ampliada à sociedade do consumo. A participação do ser humano (indivíduo), com suas singularidades, acaba por ser considerada, fator de erro. É importante termos em mente este processo, quando analisamos a relação de apropriação, pois é dentro e a partir desta relação que a subjetivação assume caráter criativo e edificante.

Chegamos a um conceito de importância crucial para o desenvolvimento deste trabalho. O conceito de propriedade. Para uma aproximação mais contundente

\footnotetext{
${ }^{62}$ Id., p. 201, passim

${ }^{63}$ MARTINS, José de Souza A aparição do demônio na fabrica, no meio da produção, Tempo Social; Ver. Sociol. USP, S. Paulo, 5 (1-2): 1-29, 1993. Ed. Nov. 1994.
} 
no sentido de esclarecer a indicação deste conceito transcrevemos uma passagem da introdução de E. J. Hobsbawm (1981) a obra Formações Econômicas Pré-Capitalista de K. Marx:

O homem - ou melhor, os homens - realizam trabalho, isto é criam e reproduzem sua existência na prática diária, ao respirar, ao buscar alimento, abrigo, amor, etc. Fazem isto atuando na natureza, tirando da natureza (e, às vezes, transformando-a conscientemente) com este propósito. Esta interação entre o homem e a natureza é - e ao mesmo tempo produz - a evolução social. Retirar algo da natureza, ou determinar um tipo de uso para alguma parte da natureza (inclusive o próprio corpo) pode ser considerado e é o que acontece na linguagem comum, uma apropriação, que é, pois originalmente, apenas um aspecto do trabalho. Isto se expressa no conceito de propriedade (que não deve ser, de forma alguma, identificado com a forma histórica específica da propriedade privada). ${ }^{64}$

Importa termos em mente que a esta interação trataremos, ao longo do trabalho como senso de propriedade, considerando que há uma tendência a interpretá-la como sujeição da natureza a vontade do homem, ou seja, de sua propriedade. Assim com denominamos senso de reciprocidade ao sentido na base do que no enunciado acima, destaca-se como evolução social. Em poucas palavras, um sistema de troca. Por isto mesmo torna-se igualmente importante enfatizar que sujeito e objeto, assim como pesquisador e objeto de pesquisa são unos dentro das experiências que transcorrem no bojo deste trabalho; que tenham como norte finalidades acadêmicas, mas que antes e acima de tudo estejamos dando continuidade ao mesmo tempo ampliando o debate que ora se faz em torno da situação de conflito existente no processo progressivo e crescente de alienação do trabalho.

Enquanto sujeito/objeto encontramo-nos em posição de encetar tais proposições filosóficas e preliminarmente às proposições metodológicas. Sobre estas dificilmente não recairão dúvidas, questionamentos e retóricas. Porém não se trata de intentar esgotar os questionamentos possíveis a respeito do determinado tema, muito menos estabelecer verdades absolutas e finitas saber pelo saber. Mas, na medida do surgimento das questões mais

\footnotetext{
${ }^{64}$ MARX, Karl. Formações Econômicas Pré-Capitalista. Rio de Janeiro: Paz e Terra, 1981, p.16
} 
pertinentes, mais promissor se torna manter a pico o nível do debate, sob a presença constante dos conflitos. Destas situações de conflitos, historicamente produzem-se, inclusive deslocamentos positivos. Da negatividade à afirmação; então, novos conflitos. Inerente e inseparavelmente, cabe às pesquisas científicas acercarem-se das fundamentações. E, para que haja progresso, para que haja deslocamento histórico-material concreto, tais fundamentações terão de ser revertida por sua vez em práxis:

A filosofia clássica alemã introduziu o conceito de "criatividade" do pensamento, mas em um sentido idealista e especulativo. [...], somente a filosofia da práxis realizou um passo à frente [...], historicizando o pensamento na medida em que o assume como concepção do mundo, como bom senso difuso na multidão [...]. Deve-se entender criador, portanto no sentido "relativo": no sentido de pensamento que modifica a maneira de sentir do maior número e em conseqüência, a própria realidade, que não pode ser pensada sem a presença deste "maior número". Criador, também no sentido em que ensina como não existe uma "realidade" em si mesma, em si e por si, mas apenas em relação histórica com os homens que as modificam. ${ }^{65}$

Assim, cabe-nos perguntar: por quanto tempo um determinado tema deve permanecer como problemática, mesmo se observando a evolução dos desdobramentos conceituais, antes de se constatar efetiva transformação social? Em Gramsci, como nos apresenta Semeraro (2006), encontramos uma argumentação que por hora poderá valer-nos como resposta:

Gramsci atribui aos elementos da liberdade e da vontade, a insistência sobre a "reforma intelectual e moral", o papel da escola e da cultura, a formação da consciência e a participação ativa das classes subalternas nas novas organizações sociais, a função positiva das ideologias a construção de uma nova concepção de mundo superior à da classe dominante burguesa e, acima de tudo, a procura dos fundamentos ético-políticos e consenso na construção da hegemonia. ${ }^{66}$

\footnotetext{
${ }^{65}$ GRAMSCI, Op. cit., pp.33-34
}

${ }^{66}$ SEMERARO, Op. cit., p.101 
Parece-nos que o esquema do conceitualismo consiste em desdobrar conceitos estabelecidos em novos conceitos. Até aqui nada se acrescenta, nossa crítica consiste na persistência de algumas problemáticas, e na relação que se faz do saber com a dominação de conceitos determinando certa hierarquia no saber. Ou seja, quando o saber determina inclusive a distinção social. Na dialética do saber uma pergunta se desfaz em novas perguntas e não há limite humano para o conhecimento. A solução de problemas nem sempre está a cargo do desenvolvimento cientifico. Assim, queremos chamar a atenção para o tempo que muitas teorias permanecem alijadas de alguma práxis criativa.

O homem, entretanto, é também sujeito/objeto do desenvolvimento histórico das ciências; assume originalmente, postura argumentativa com relação ao devir histórico, mesmo que muitas vezes esta postura não se reverta em uma mudança de postura isto é perpetue-se como forma. Desde estabelecida na história a divisão da sociedade em classes e níveis, com base na determinação da mais-valia e na acumulação, tem-se percebido tão somente uma transmutação do sistema de dominação dos poderes hegemônicos.

Assim, enquanto o sistema de trabalho fordista e taylorista era orientado a mecanizar o corpo e a disciplinar a vida familiar e social o atual modelo concentra sua dominação na mente, no imaginário, atinge o inconsciente do trabalhador-consumidor isolado socialmente. $O$ que está em curso, na verdade, é a taylorização da inteligência, quer dizer, a submissão das energias mais criativas e cooperativas do ser humano à extração da mais valia. ${ }^{67}$

Sujeitos ao consumismo e a mercantilização globalizados onde a informação é moeda de troca e também mercadoria, temos permanecido cada vez mais distante de mudanças significativas, principalmente na área das Ciências Humanas. São exemplos desse distanciamento, as idéias atuais de patrimônio imaterial correspondente a cultural popular que amplia a dedicação a projetos de preservação, mas não promove um entendimento deste patrimônio com objetivos precisos na direção da autonomia implícita neste saber. Ou seja, ideal que este patrimônio resista, no tempo, como memória de um (outro) tempo

${ }^{67}$ Ibid., p.117 
histórico e, em algum lugar como prova de uma pseudo-marca identitária. Por um lado, uma corrente levantava a importância das atividades peculiares de comunidades cujo modo de vida se define como primitivas, arcaicas ou tradicionais (trabalho rústico, ferramentas, manifestações expressivas etc.); por outro, percebeu-se que atrelados a estas atividades carreavam se conhecimentos fundamentados na própria vivência dos grupos nos ambientes (sobre o tempo, sobre a terra, sobre a saúde, sobre a formação etc.); e sua diversidade e conhecimento, baseavam-se na experiência viva e cotidiana ou no que Hardt e Negri(2005) chamaram de produção imaterial ou biopolítica. ${ }^{68}$

Até aqui o que podemos concluir é que toda a ênfase que passou a circundar estes modos de vida e de saber tem servido apenas para o fomento de uma ordem neoliberal que os computa dentro da estética mercantilista do consumismo; para o pragmatismo estes modos de vida contêm uma linguagem que reforça o caráter de distinção. Ainda dentro do enfoque daqueles autores, onde defendem tenazmente a possibilidade de uma democracia global, emerge também o conceito de biopoder, que aqui nos interessar para uma visualização breve das complexidades no terreno onde estamos pisando. Apontam, eles para uma forma global de poder imperial, e as características de uma guerra imperial global;

[...] a aplicação constante e coordenada da violência torna-se condição necessária para o funcionamento da disciplina e do controle. Para que possa desempenhar este papel social e político fundamental, a guerra deve ser capaz de desempenhar uma função constituinte ou reguladora: terá de tornar-se ao mesmo tempo uma atividade processual e uma atividade reguladora, de ordenação, criando e mantendo hierarquias sociais, uma forma de biopoder voltada para a promoção e a regulação da vida social [...] o estado de guerra regulador da nossa época imperial reproduz a ordem vigente; ele cria a lei e a jurisprudência desde o interior. Seus códigos jurídicos são estritamente funcionais em relação à constante reordenação de territórios imperiais. ${ }^{69}$

Apesar de que muitos autores vêm tratando deste evidente estado de guerra, e de que não se trata tão somente da guerra armada e de um inimigo concreto,

\footnotetext{
${ }^{68}$ HARDT; NEGRI, Op. cit. pp. 165-194

${ }^{69}$ lbid., pp. 44-45
} 
mas de um inimigo abstrato, não nos deteremos por muito mais nesta questão, porém não podemos nos furtar a oportunidade de apontar para o modo como isto nos tem afetado, quando estudamos as condições de vida e trabalho das classes dos desfavorecidos frente aos monopólios empresariais. Correspondente a esta ordem desde há tempos estabelecida, em um único exemplo podemos observar a força e a abrangência do poder imperial, o da empresas florestadoras (vale frisar que não há muita precisão na denominação desta atividade: se florestadoras por que constroem florestas com espécies de crescimento rápido, ou se reflorestadoras, pois recompõem florestas degradadas) e produtoras de celulose em várias regiões do Brasil, mais especificamente em locais de grandes aqüíferos, como o Vale do Paraíba, no Sudoeste Paulista, região a qual se refere este estudo. Questionando o jogo político-jurídico de que fazem uso com o objetivo de tomar grandes extensões de terra, fomentam o plantio de eucalipto e outras espécies de crescimento rápido; desmatam, poluem o solo e os mananciais, destroem biomas completos expulsando espécies nativas da fauna e flora, criando um grande "deserto verde" $" 70$ em contra partida e paradoxalmente apóiam projetos educacionais de preservação do meio ambiente. Isto nos interessa de forma direta uma vez que, com a expansão de monoculturas também se esfacelam os ambientes originais de produção de uma cultura própria cujo potencial comunitário de produção e auto-reprodução the permitiu, até os dias de hoje, auto-preservação. Não devemos deixar de considerar que se trata, então, de um inimigo camuflado pela falsa pele do desenvolvimento e do progresso e também por um assistencialismo predador. Quando muitas vezes, mediante este tipo de ataque usamos a expressão resistência cultural, e nesta resistência salientamos a capacidade de revide contra tais inimigos perguntamos: quais armas restariam às classes subalternas, sendo que poderio econômico não está dentro de seu alcance? Armas ideológicas? Que não se entenda esta proposição como brado revoltoso e apaixonado, mas que antes de qualquer coisa se leve em consideração como propósito dos estudos sobre aqueles potenciais comunitários, não somente iluminação científica, mas também a verdadeira práxis. Depois, estas armas estão carregadas dos sentidos essenciais de uma

\footnotetext{
${ }^{70}$ MOVIMENTO de Mulheres Camponesas -MMC Brasil. Deserto Verde: 17/08/2006; Disponível em 4http://www.mmcbrasil.com br/notícias/170806 deserto verde.hth $>$ acesso em 21/08/2006
} 
ideologia das classes subalternas cuja destruição (negação) é dialética. Como ferramentas ou instrumentos não foram suficientes para se superar o sistema de cooptação do tipo "identidade cultural, identidade nacional"; como armas, vamos às perspectivas de negociação. No uso destas armas, contudo não há violência, todavia não se faz sem energia, força (de vontade); não há estrondo nem dilaceramento da carne, há expressão e criatividade; não há imposição nem dominação, mas reconhecimento orgânico das hegemonias. Já enfatizamos o poder de resistência de manifestações culturais de profunda pertinência histórica, mas resistir por resistir corresponde a um poder estático que só faz absorver os golpes; é necessário um movimento, uma reação e um deslocamento.

Ao anunciar enfaticamente que "nunca como hoje o Brasil (e por que não toda a America Latina considerando a formação colonial de suas nações), precisou tanto de novos intelectuais orgânicos, Semeraro destacando outro ensinamento de Gramsci vem de encontro àquelas perguntas:

A partir do momento em que um grupo subalterno se torna realmente autônomo e hegemônico, suscitando um novo tipo de Estado, nasce concretamente a exigência de construir uma nova ordem intelectual e moral, ou seja, um novo tipo de sociedade e, portanto, a exigência de elaborar os conceitos mais universais, as armas ideológicas mais sofisticadas e decisivas. ${ }^{71}$

Verificamos que os pensadores consideram vocativamente, a existência destas armas. Caberá àqueles que se pretenderem intelectuais ${ }^{72}$ (orgânicos) assumir ou não a tarefa de localizar, identificar e potencializar este arsenal? Não sem antes admitir que se trate realmente de uma guerra e onde não se pode mais permanecer num estado unicamente de resistência, mas, não será hora de que avançar sobre as forças opressoras? Não sem antes bem assimilarmos a amplitude do caráter orgânico desta investida. Não se trata, entretanto de assumir o poder, mas de dar reconhecimento e oportunidade a novas

${ }^{71}$ GRAMSCI,1975 apud SEMERARO, 2006, p.150

${ }^{72}$ PORTELLI, Op. cit., p 15 "Se considerarmos um bloco histórico, isto é, uma situação histórica global, distinguimos aí, por um lado, uma estrutura social - as classes que dependem diretamente da relação com as forças produtivas -e, por outro lado, uma superestrutura ideológica e política. O vínculo orgânico entre esses dois elementos é realizado por certos grupos sociais cuja função é operar não ao nível econômico, mas superestrutural: os intelectuais." 
hegemonias. Estas ultimas, sob uma apreciação fragmentária mostram as faces utilitárias e mecanicistas do objeto. Porém enquanto unidade, integram teoria e prática.

Antes de um aprofundamento na definição do que e, quais seriam estas armas ideológicas voltemos à questão do sujeito/objeto. Para complementar nosso raciocínio sobre a posição que ocupamos nesta batalha para estabelecimento de uma nova ordem, devemos apontar, sendo outra faceta peculiar ao homem, o que lhe confere autonomia entre o arrefecimento perante um processo de homogeneização cultural ou uma auto-determinação segundo seu discernimento, isto é, sua atuação política, sua ação decorrente ou não de um empreendimento filosófico próprio ou imposto externamente. Neste caso devemos considerar que dificilmente constatamos grandes grupos sociais com autonomia suficiente para determinar sua própria maneira de pensar e agir dentro da relação entre flexibilidade e fluidez das fronteiras e o Estado. Mediante toda individualização o que observamos ainda são os esquemas de subordinação e submissão.

"A ciência está indissoluvelmente imbricada com a política, pois o cientista tem uma responsabilidade social da qual não pode abdicar"73. Baseando-nos nesta premissa podemos argumentar que somente através de práticas políticopedagógicas comprovamos historicamente êxito em um deslocamento humano em busca de seu aprimoramento e evolução. Não que ao longo deste caminho o homem não tenha aprendido com o erro, (que também pode significar que um passo atrás não corresponda a atraso, mas dois adiante em outra direção), mas que são muito mais marcantes e gratificantes as conquistas coletivas (mudanças constitucionais, direitos trabalhistas, reforma agrária, demarcação de terras indígenas etc.).

É nesta concepção de possibilidade ${ }^{74}$; de mudanças e de conquistas coletivas na qual ambientamos o estudo que aqui se desenvolve onde formulamos em tese que este movimento prenuncia uma procura por sentido. "Daí a importância dada ao sentido, à rede de significações [grifo da autora] que

\footnotetext{
${ }^{73}$ FERREIRA, Op.cit., p.28

${ }^{74}$ HELLER, Op. cit., p. 74
} 
envolve os objetos percebidos: A consciência vive imediatamente como doadora de sentido ${ }^{75}$ ". Propomos então como fórmula estes dois termos fundidos, procura/sentido. Calculamos esta fórmula como correlata ao binômio sujeito/objeto (saber/construir); fundidos os termos justificamos a idéia de um deslocamento que por sua vez, dentro da cadeia espaço/tempo consubstanciam a história; é desta substância que podemos haurir o conhecimento que houver de mais significativo, para ser confrontado positiva ou negativamente com a "realidade imediata" e as transformações sociais necessárias. Não se trata evidentemente de uma simples operação de integração entre "um sujeito e um objeto" em sua contingência histórica. Há necessidade de se perscrutar a complexidade desta relação.

Não é que (a alternativa dialética), dissolva as fronteiras entre Sujeito e Objeto, ou que "misture" ambos e os torne uma unidade cindida, mas o que faz é entender toda a relação entre um objeto e um sujeito do conhecimento não como uma relação dualista, mas uma relação na qual o sujeito deve introduzir-se no objeto de conhecimento de maneira tal que, consumada sua relação com ele, assuma a relação que existe, não anulando-a ou suprimindo-a. Esta ação parte da negação do Objeto como Objeto (negação dialética do Objeto em si mesmo) para ser entendida como uma unidade entre Sujeito e Objeto. O Sujeito também nega-se a si próprio como sujeito, mas reconstrói em sua relação com o Objeto. [...] a inclui como um aspecto parcial da totalidade. ${ }^{76}$

Vale dizer que o que interessa é um sentido de unidade e a perspectiva de uma totalidade. Um deslocamento contínuo e criativo, peculiar as atividades humanas; oposto a uma marcha inútil, um êxodo sem fim para uma massa informe de indivíduos.

A este ponto convêm abrir margem para a crítica a exemplos de vícios de linguagem na recorrência do uso dos termos resgate e resistência, pela aplicação usual quando se discutem as referentes manifestações culturais como tradicionais e como representações das diversidades e identidades. Pelo fato de que é através das palavras que se apregoam normas de condutas, e,

\footnotetext{
${ }^{75}$ FERREIRA, Op. cit., p. 35

${ }^{76}$ Ibid., pp. 113-114, passim
} 
como tais devem ser filosoficamente confrontadas com a política em questão. Não é raro encontrarmos quem os adote como mecanismo de salvação e de sustentação, respectivamente, de formas de comportamento representativas de um povo, uma comunidade ou ainda uma classe. Necessária se faz uma observação crítica pela ambigüidade daqueles termos, quando se menosprezam os sentidos etimológicos e históricos; quando aplicados a condições parciais isoladas, principalmente quanto ao termo resistência. Contudo, até aqui o uso destes termos ainda não serviu de forma objetiva a qualquer transformação efetiva, pois apenas definem um estado de coisa, sem projetá-las a uma dada sublevação, a um passo adiante; e, também por se resumirem a resíduos ideológicos liberais elitizados quando referidos principalmente á formas culturais de expressão. Ou seja, passaram a referenciar as aparências de preservação da inércia nestas formas tão dinâmicas.

A saber, o primeiro caso, mais simplista refere-se ou a um procedimento econômico financeiro de compensação, o resultado de um investimento, o pagamento de uma dívida; ou a uma operação que se realiza imediatamente após o desastre na tentativa de recuperar o que está destroçado, neste ultimo caso quando há êxito dificilmente é sem seqüelas. De fato, em se tratando de modos culturais, quando uma forma de expressão de qualquer natureza chega a acabar, pela extinção de seu ambiente original quase sempre é em definitivo, não tem resgate, não há como reconstituir completamente uma estrutura quando alguns elementos foram definitivamente aniquilados (uma floresta, 0 pátio de uma capela, um dialeto, afetividades, oportunidades de experimentação, relações pedagógicas não-formais etc.), em outros casos a forma de expressão ou manifestação cultural sofre uma completa metamorfose em função de uma ideologia dominante a exemplo do que ocorre com a música popular no Brasil:

O neoliberalismo fez com que a musica se tornasse um produto de prateleiras como as do supermercado; só é bom se vende bastante. [...] percebemos que a música popular brasileira, a histórica MPB, que sempre esteve atrelada à realidade e aos acontecimentos do país deixou de ser objeto de divulgação da mídia que naquele momento passou a investir em gêneros emergentes, como uma nova modalidade de rock nacional e 
músicas sazonais como axé, no verão, salsa, timbalada, macarena e uma série de gêneros fabricados. A autêntica musica sertaneja já desde os anos de 1970 viera cedendo espaço a uma modalidade de sertanejo romântico que emplacou nos anos de $1990 .^{77}$

Vale acrescentar que muitos destes gêneros são estilizações bastante palatáveis ao consumismo imediato, massivo e descartável.

No segundo caso, na usual aplicação do termo resistência, devemos dar mais destaque a maior implicância histórica uma vez que não se pode menosprezar vasta e diversas genealogias de movimentos significativos de luta de povos subjugados contra o poder. Acompanhemos a análise feita sobre a "Resistência"78[grifo nosso] feita por Hardt e Negri (2005). Em primeiro lugar uma observação sobre onde se posiciona esta postura, por um lado como reação a um estado de opressão e por outro fazendo alusão à metodologia marxista, a respeito de exposição (o capital, a riqueza como resultante do trabalho) e investigação (... reconhecendo que na realidade o trabalho é que é primordial). Assim, argumentam que a resistência é primordial em matéria de poder:

As subjetividades que se revelam na investigação são os autores da nova realidade, os verdadeiros protagonistas da história. [...] Sua investigação (Marx) sobre a natureza do trabalho e da produtividade dos que são explorados pelo capital não se orienta apenas para uma nova visão do mundo, da perspectiva deles, mas também para uma nova realidade criada de sua atividade histórica. ${ }^{79}$

Com base nesta colocação, não se pode deixar de considerar o que estes autores propõem como subjetividades da resistência, argumentando em ultima análise, que em termos filosóficos, a produção envolvida aqui é a produção destas subjetividades; a criação e a reprodução de novas subjetividades na sociedade. "Quem somos, como encaramos o mundo, como interagimos uns com os outros: tudo isto é criado através dessa produção biopolítica e social. [...] na comunicação, colaboração e relações afetivas." ${ }^{80}$ Portanto, não se pode

\footnotetext{
${ }^{77}$ VILELLA, Ivan. Música no Espaço Rural Brasileiro - Piracicaba Orquestra Sinfônica de Piracicaba, 2008. p. 20

${ }^{78}$ HARDT; NEGRI, Op. cit., p. 97, et. seq.

${ }^{79}$ Ibid., p. 99

${ }^{80}$ lbid., p. 101,
} 
admitir qualquer superficialidade na aplicação da resistência figurativamente como o que se confere a algo como sendo apenas a capacidade de subsistir; como um esteio natural, sujeito as intempéries, restando-lhe com o passar do tempo ser substituído por algo ainda mais resistente e moderno, sem que se faça jus "a toda genealogia das lutas de libertação, da formação dos exércitos populares nas grandes revoluções modernas à guerra de guerrilha e finalmente ás formas contemporâneas de luta e rede." 81 Consideramos de igual importância, o que estes autores apresentam, com relação às formas de resistência como três princípios orientadores, de maneira sucinta: a oportunidade histórica, uma correspondência entre as formas de resistência e a transformação da produção econômica e social e a democracia e a liberdade ${ }^{82}$.

Há ainda um terceiro equívoco correspondente ao entender a resistência como um escudo que tenta coibir a contaminação por influência e aproximação de outras e novas culturas no que se insiste em chamar de culturas fechadas como minorias étnicas e comunidades primitivas como quilombos e aldeias indígenas ou de pescadores etc., mais comprovável na América Latina e em especial no Brasil mediante os "híbridos culturais"83. Devemos observar que nestes casos muitas vezes as fronteiras são impostas de fora. E, para as elites dominantes tratam-se de pequenas relíquias nacionais colecionadas ao contexto de origem, de formação do Estado-nação, apesar dos extremos de pobreza em que muitos vivem.

Ao tratarmos de subjetividades estamos inclinados a identificá-las no contexto das expressões artístico-culturais, mas tendo como pano de fundo o mundo do trabalho e das relações de produção. O caráter de resistência atribuída a este conjunto nos serve como indicativo das possibilidades de transformações sociais. Dentro das propostas aqui desenvolvidas sobre as singularidades humanas, a aplicação habitual da terminologia resistência, quando em referência a como têm se mantido os grupos e as manifestações culturais do Brasil e da América Latina, somente as deverá fazer permanecerem conformadas sob opressão, subjugando aos seus mecanismos de articulação.

\footnotetext{
${ }^{81}$ Ibid., p.103

82 lbid., pp. 98- 103, passim

${ }^{83}$ HALL, Op. cit., p.62
} 
Estes mecanismos, lembramos, são vistos aqui com representativo potencial transformador; tornando-se obscuras, as singularidades passam a decretar a falência dos sujeitos. Esta obscuridade hoje pode ser identificada sob o nome de "multiculturalismo". Bauman (2003), tomando por base o pensamento de Cornelius Castoriadis (1997), observa que:

O reconhecimento do "direito humano" (à diferença), [...] é, isso sim, um convite para um diálogo no curso do qual os méritos e deméritos da diferença em questão possam ser discutidos e (esperemos) acordados, e assim difere radicalmente não só do fundamentalismo universalista que se recusa a reconhecer a pluralidade de formas que a humanidade pode assumir, mas também do tipo de tolerância promovido por certas variedades de uma política dita "multiculturalista", que supõe a natureza essencialista das diferenças e, portanto, também a futilidade da negociação entre diferentes modos de vida. ${ }^{84}$

No debate proposto aqui o foco não é especificamente a questão da diferença ou do direito à diferença, que são correlatas e inquestionáveis da esfera das subjetividades humanas, mas sim o fato de que muitas das abordagens e formas de abordagem a amplitude do tema cultura têm sido inócuas quando não pressupõem possibilidades efetivas transformações na sociedade; quando se deixa de considerar a indissolubilidade do sujeito, que tudo o integra explícita/implicitamente. Se acompanharmos mais de perto o pensamento deste autor sobre multiculturalismo, verificaremos que parte do problema implica a atividade do que chama de "classes ilustradas" e que multiculturalismo, como em outras meta-linguagens, serve como resposta evasiva, canônica e indiferente da parte destas classes aos que buscam ali conhecimento e aos que se esperavam fosse ética sua postura social. Na visão de Bauman (2003) esta classe ilustrada, em conjunto com "os poderes econômicos cada vez mais extraterritoriais, com uma sociedade que cada vez mais envolve seus membros no papel de consumidores e não de produtores, e com a modernidade cada vez mais fluida, "liquida", desregulamentada", sofre duas transformações importantes para que entendamos um tanto mais o problema social que hoje enfrentamos; a "primeira é o desengajamento como

\footnotetext{
${ }^{84}$ BAUMAN, Op. cit., p.74
} 
nova estratégia do poder e da dominação; a segunda - o excesso como substituto de hoje para a regulamentação normativa. ${ }^{85}$ " uma espécie de cada um por si em que foram deixadas as sociedades dos despossuídos, em cujo caminho incerto se observa o autocontrole e a autodestruição.

Neste segundo caso a falta de uma orientação redunda em uma infinidade de opções de caminhos e alternativas, porém a liberdade para escolher não quer dizer exatamente oportunidade de se fazer uma escolha mais acertada, mas que em caso duvidoso, permanece a liberdade para uma ou novas escolhas, ao que nos parece este tipo de liberdade não tem levado a saída deste extenso labirinto da busca pela construção da identidade. Assim, estas duas transformações que preliminarmente traduzem o esquema do multiculturalismo, nos ajudam a compreender o descaminho por onde têm se enveredado os estudos sobre cultura no Brasil e na América Latina quando ainda obedecem à "ultragenerelização" ${ }^{86}$ do saber pressuposta nos modelos eurocêntricos e norte americano.

De acordo com uma demanda por identificar alternativas que rompam com este estado de opressão e representem um ambiente mais satisfatório que corresponda a mais oportunidades ao maior número de sujeitos em qualquer esfera, integrados e interados; por se arrastar a tanto tempo o debate a respeito de uma práxis alternativa de humanização da sociedade, postulamos sobre a possibilidade de resiliência. Consideramos por esta capacidade, que formas de manifestação e expressão cultural possam se re-edificar, mesmo depois de solapadas; sendo próprias de um momento de estruturação social baseada na relação homem e seu meio de trabalho ainda que dividida em classe a sociedade, não raro constatamos circunstâncias de identificação, de apropriação e reciprocidade. Da mesma forma como na ecologia, ao se restaurar um determinado ambiente, reestruturam-se os respectivos habitats, reformulam-se os biomas, (pelo menos é o que cientistas desta área tentam fazer), mesmo quando já faltam peças importantes. A identificação instrumentaliza o individuo para o conjunto das relações no qual está inserido; pela apropriação e reciprocidade cria e recria o diálogo com o habitus, que em

\footnotetext{
${ }^{85}$ Ibid., pp. 112-113, passim

${ }^{86}$ HELLER, Op.cit., p. 34
} 
muitas circunstâncias traduz-se em complacência estética. Não deixamos, porém de tratar de algo da esfera das subjetividades das relações de trabalho; perguntamos se na possibilidade de, uma vez re-estruturada ou re-conquistada as relações de propriedade e reciprocidade de fato, sobre determinado ambiente de condições objetivas de trabalho, sendo ele rural ou urbano, ou ainda de pequenos produtores, não teríamos daí, por conseguinte, o indicativo de uma re-estruturação ético-política de sujeitos? Isto é, mesmo tendo sido deformado em parte ou no geral, o ambiente no qual o homem desenvolveu sua capacidade de transformar a matéria em função dos aprimoramentos técnicos, sua capacidade de subjetivação para projetar a transformação pode ser condicionada, porém não se desfaz nem diminui. A nosso ver com oportunidade e liberdade aumenta e diversifica a partir das possibilidades de identificação e apropriação. Contudo, estes mecanismos em mãos liberais impulsionadas pela força sedutora do capital são os catalisadores da individualização e da acumulação. Mas para filosofia da práxis esta é uma perspectiva de unidade, formam "o corpo objetivo de sua subjetividade" ${ }^{87}$.

É por este viés que se propõe aqui o estudo da ideologia implícita nas manifestações culturais subalternas. Assumimos filosoficamente a idéia de um caminho, agora, ideológico a percorrer. "A ideologia é indispensável para o funcionamento da sociedade" ${ }^{\prime 8}$.

[...] Tudo, pois o que se move, está em falta de alguma coisa, e não tem juntamente todo o seu ser. $[\ldots]^{89}$.

Buscamos identificar e distinguir a ideologia fundamentada na tese que tem como núcleo o nexo procura/sentido. Se a procura pressupõe um deslocamento, já uma ação concreta, o trabalho objetivo; o sentido corresponderá ao conjunto das subjetividades que (se) complementa (n)o trabalho objetivo ou o seu inverso, quando o trabalho objetivo ganha representação subjetiva.

\footnotetext{
${ }^{87}$ MARX, Op. cit. p. 67

${ }^{88}$ FERREIRA, Op.cit p.75

${ }^{89}$ ALIGUIERI, Dante. Obras Completas, v X, São Paulo: s.d., p. 149
} 
Para adentrarmos nessa perspectiva de identificação e distinção da ideologia, e para que esta não incorra em digressões, devemos tentar projetar qual o seu fim. Para que servirá. Não pode haver outra perspectiva senão aquela a visualiza o homem vivendo em sociedade. "O homem deve ser concebido como um bloco histórico de elementos subjetivos e individuais e de elementos de massa - objetivos ou materiais - com os quais o indivíduo está em relação ativa." 90

Quando olhamos através da perspectiva que divide esta concepção do homem em duas visões, calculamos que uma deva ver o homem como um complexo biológico a mercê dos avanços tecnológicos que ele mesmo produziu e produz, seu progresso é a causa de seus males; a outra vê o homem-massa, como resultado das incongruentes transformações em suas relações sócio-culturais.

Aqui duas abordagens diversas e ao mesmo tempo unas em torno de um elemento central: o fazer, ou reproduzir-se. Uma destas abordagens afeta diretamente sua existência físico-biológica, ou seja, sua capacidade motora de discernir e operar; a faculdade de se auto-comandar em tarefas físicas. Como ser vivente o homem nasce no planeta, sofre mutações conforme o contexto histórico (consideramos esta mutação em termos mesmo da "plasticidade" na compleição sensorial-fisiológica) desenvolve-se criando demandas e transformando o ambiente; pode procriar ou não, consome e morre. Os problemas são problemas da vida. Contudo, reproduz-se renovando constante e progressivamente suas formas de relacionamento; persiste enquanto espécie pela versatilidade em explorar, transformar e consumir, diversificada e infinitamente - à escala do esgotamento. A outra abordagem se refere à questão da vida (humana), à ontologia, ou seja, o conceito de existência como consciência, ou ainda de experiências para tomada de consciência e, a respeito do qual, nas ciências humanas desenvolvem teses e antíteses na busca infinita de formular teorias que justifique e perpetue esta existência - o sentido.

Em face da primeira consideração, importa destacar que ao longo de sua existência o ser biológico se adapta e mais conseqüentemente corrige-se

${ }^{90}$ GRAMSCI, Op. cit., p. 47 
conforme sua cultura. Além das adaptações plásticas, estéticas (piercing, silicone etc.), desde a adoção da postura ereta até, por exemplo, a adaptabilidade as modalidades esportivas, onde recordes são superados em competições mundiais, a adaptabilidade aos tecidos produzidos em laboratório, a partir da engenharia genética, a adaptabilidade a roupas, calçados, aos estímulos da vida nomeio urbano etc.; contudo, o organismo humano sofre as influências do meio e conseqüentemente diversifica suas relações de produção (fica difícil imaginar vivermos sem automóvel, televisão, luz elétrica etc., estando tais tecnologias completamente integradas ao cotidiano).

Devido a tantos estímulos aos quais se está constantemente sujeito, como poluição do ar, o aquecimento global, extinção definitiva de espécimes e biomas, intensidades de sons e ruídos, velocidade, exposição a meios radioativos e a alimentos de procedências não orgânicas, conseqüentemente todo o metabolismo humano, tenta se adaptar, reforçando seus sistemas de defesa, criando reflexos e escudos externos. Exemplo preocupante de uma situação oposta é quando se julga o ser biológico adaptado, sua evolução e suas condições históricas o colocam como espécie que dominou a natureza. Mas, ao se observar a incidência de patologias avassaladoras, que atingem os mais desfavorecidos, que são a grande maioria da população, não negamos os progressos das ciências médicas, porém constatamos que fragilmente o ser biológico tem superados os seus recursos. A descoberta eufórica dos antibióticos sintéticos ilustra bem esta observação. Os microrganismos desenvolvem processos de adaptação e resistência contra a eficácia das substâncias químicas mais especializadas. Há uma necessidade constante de atualização do potencial deste tipo de medicamento pressupondo inclusive, maior desenvolvimento da indústria farmacêutica, contudo, não se exclui nem se extingue um estado pleno de combate. Com isso, os sentidos defensivos criam, instintivamente, sistema de assimilação ou barreiras biológicas para preservação e perpetuação da espécie, mesmo que no curto espaço de tempo de uma vida em relação ao existir da espécie, não sejam perceptíveis estas adaptações. No entanto mais velozes são as edificações das fronteiras que separam os que vivem em segurança e os que estão mais vulneráveis. 
O que estamos tentando afirmar é que, a exemplo desta visão, do homem a mercê de sua tecnologia persistem ainda as tendências de cisão entre objetivo e o subjetivo, entre quantidade e qualidade. Por isso quando abordarmos ao ser, quanto à existência, tem-se buscado os argumentos para uma interpretação mais plausível para a história do desenvolvimento humano.

É importante frisar que estas considerações aos aspectos biológicos e ontológicos do homem, não se restringem somente na diferenciação das condições da vida, mas as condições objetivas de vida e de trabalho, pois toda transformação, têm sua matriz no movimento de "apropriação", ou seja, na forma como o indivíduo se integra e absorve do ambiente; o explora e o condiciona para vida. Seja este ambiente objetivo ou subjetivo. Se de um lado a relação material conduz ao progresso e suas conseqüências, de outro a insuficiência de esclarecimentos e da compreensão em torno da capacidade de subjetivação sobre aquela relação faz com que tudo possa ser objeto de transação - ter valor de troca. O refrão freqüentemente repetido entre as celebridades televisivas desde os palanques até os debates transnacionais, a saber, melhoria da qualidade de vida (vida biológica: melhor ar, melhor alimento, melhor água, melhor lugar para se morar melhores condições para se locomover e se comunicar etc.), além da metalingüística se carrega sempre de uma unilateralidade quantitativa. Uma parte é feita pela natureza, a outra se gerencializa assinando-se este ou aquele tratado até que o que tem que ser explorado o tenha sido completamente. E claro, não nos esqueçamos que a ordem sócio-econômica e cultural continua a ser ditada pelo capitalismo global.

Assim, ao longo do desenvolvimento histórico da filosofia muitas teorias aspiraram à lógica; ou, categóricas como a metafísica afirmativa de ser o homem fruto de uma vontade divina. Outras se fizeram registrar através da tradução do "ser" de acordo com esferas de atuações, compondo-lhe em compleições diversificadas, complexas, multíplices: o centro do universo, o rei dos animais, centro da História; o condutor da História, o homem-massa. Mais sedimentada, enfim, a fragmentação do conhecimento, outras interpretações são propostas pelo prisma do desenvolvimento científico diversificado em 
disciplinas ou áreas de compreensão como Filosofia, Psicologia, Antropologia, Sociologia que a posteriori tentar-se-ão articular, nomeadamente, através da interdisciplinaridade ou da transdisciplinaridade, que não podem ser consideradas como outra coisa senão a imaginação de um possível "caminho de volta". Uma tentativa de reorganização dos saberes, coadunando-os para se decifrar os por que da trajetória humana. Assim mesmo não garante este entendimento uma vez que há um regime que organiza as disciplinas mediante qualquer escala de prioridade e ainda continua faltando a práxis definitiva.

É razoavelmente possível se admitir que o homem, genericamente inclui-se como bem-capital apropriável dentro do processo que se auto-estimula na articulação e na manutenção do capital, seja no campo político ou econômico e, que tem como arma de controle a dependência (necessidade do consumo). "A produção assume uma qualidade objetiva como se o sistema capitalista fosse uma máquina que marcha por conta própria, um autômato capitalista." ${ }^{91} \mathrm{Em}$ outras palavras, pouco a pouco o homem-genérico transforma-se em uma massa biológica que consome, a medida que se destitui das possibilidades, das oportunidades e da personalidade. De elemento central o homem passou a dissolvido enquanto substância que se reproduz aumentando seu corpo e ocupando os espaços possíveis - as cidades - a serem administrada sob as previsões dos poderes mais o comércio. Ao mesmo tempo em que contraria os próprios princípios da sobrevivência como animal predador, esta massa de indivíduos humanos consome-se a si própria enquanto é capaz de produzir as mais diversificadas armas de destruição em massa com objetivos bélicos e as indevidas e inconseqüentes explorações (combustíveis fósseis, produtos transgênicos de efeitos colaterais não comprovados, traumas e distúrbios psicossomáticos dos grandes centros etc.).

Mais que faculdade psico-social, o desejo é fator essencial da habilidade construtiva. $O$ consideraremos princípio motor para o que inicialmente chamamos deslocamento ou o princípio detonador das ações cognoscitivas (não-instintivas, intuitivas, perceptivas, receptivas), em especial dos movimentos construtivos isto é do real e do histórico. Assim também se traduz

${ }^{91}$ HARDT; NEGRI, 1995,apud SEMERARO,2006, p. 118 
em desejo a pretensão de construir argumentos ou de formular teorias, explicar e entender a realidade. Faz se necessário a este ponto conduzirmos esta reflexão as dimensões do conhecimento e da representação; por complementares, uma a outra, mas ainda pelo fato de que buscamos sempre representar (ou sermos representados em) algo que possa ser evidenciado, ou que tenha maior poder de evidência, ou que reúna os qualificativos para que (se) represente - são processos coletivos - apesar de ocorrerem em cada consciência individual; caso contrário, sem serem evidenciadas as representações não vão alem de elucubrações. Neste caso o conhecimento enquanto saber científico não é freqüentemente a maior prerrogativa. Não necessariamente conhecemos a fundo o que se nos representa. Porém, ambas as dimensões consideradas são estritamente necessárias para a experiência da realidade. De um lado a experiência pressupõe o conhecimento ou ao menos uma acepção, e, esta por sua vez poderá ganhar representação na consciência humana. Concernente a idéia de deslocamento, saída de um estado para outro, as representações plasmam-se do mundo objetivo em produções subjetivas e objetivas que se reproduzirão em novas representações numa espiral dialética - o novo sobre a experiência do passado. Considerando como exemplo a experiência de uma sensação de prazer ou desprazer, algo da esfera dos interesses do indivíduo, o campo da imaginação dará amplitude a esta sensação e carregará de possibilidades de representação o que se projetar subjetivamente - a capacidade de subjetivação. Dentro destas possibilidades, diferente do conhecimento como domínio individual de tecnologias e habilidades, é interessante considerar a representação como compartilhamento voluntário ou involuntário do que possa despertar a sensação. Podemos atribuir à natureza (como tudo o que está pré-posto ao conhecimento ou a transformação), a condição de fonte das subjetividades, uma co-participante dos processos que geram as sensações ou complacência. Fruto da simbiose entre sujeito e objeto neste processo construtivo. Será a natureza o elemento que favorecerá os processos de descoberta e construção de conhecimento e que por isso mesmo, se reconhece como essencial neste processo. Não se pode com esta proposição atribuir qualquer intencionalidade à natureza, mas importa considerar um movimento oscilatório do exterior para o interior e vice-versa, com relação ao sujeito, referindo-se às faculdades 
receptivas e perceptivas. O que se propõe ter em conta é, então, a existência do "outro" o qual se percebe ou ao qual se projeta como receptáculo da representação - a coletividade. Assim acreditamos nos aproximar do caráter do simbólico. A transferência de representatividade para o signo:

É importante observar que as "novas" formas discursivas da indústria cultural têm muito a ver com a velha arte retórica, concebida pelos sofistas e sistematizada por Aristóteles. [...] Descartes, com sua entronização do sujeito pensante (o cogito ou espírito autônomo diante de Deus) que acaba com as relações de transparência entre homem e mundo, criando uma esfera mediadora chamada "representação". "Representar é fenômeno em que o sujeito delega a um outro (o representante, o signo) o poder de interpretá-lo em sua ausência. ${ }^{92}$

Mesmo sendo este simbólico comumente suposto como metafórico, alegórico ou utópico, não está em questão o simbolismo, mas é algo que também podemos identificar como inerente ao indivíduo ou a sua carga essencial de subjetividade. Se na sua complexa configuração psico-social o homem traz esta carga, necessário se faz traduzi-la em esferas de vários conjuntos: como dos sonhos (de consumo), da política (a sociedade), das leis (a moral), da religião (o sagrado). Mesmo dentro desta concepção de simbólico-metafórico encontraremos uma gama de representações as quais poderemos identificar "como forças produtivas especiais tanto objetivas como subjetivas, as ultimas emergindo como qualidades do indivíduo." 93 Representações estéticas ou epistemológicas que, direta ou indiretamente produzem-se ou atuam enfaticamente sobre o emocional e o cognitivo. Abordamos a um âmbito cultural de produção de objetos que comportarão aspectos, que neste ponto de vista, visam complementar a configuração do ser, interna e externamente. Em outras palavras, nos referimos a um universo de projeções sistêmica e expressivas; objetos ao mesmo tempo introjetados e remotos representados em práticas cotidianas. Consideramos que como objetos tais projeções venham a complementar como constructos esta compleição humana, prospectivamente

\footnotetext{
${ }^{92}$ SODRÉ, Op. cit., p.23

${ }^{93}$ MARX, Op. cit., p. 89
} 
com base na concepção do homem no mundo, dotado de suas consciência e razão, mas acima de tudo por sua existência, como parte material e imaterial de sua auto-reprodução. O que se quer afirmar e ao mesmo tempo se postular enquanto questão é a amplitude das dimensões conhecimento/representação impressas em atividades as quais, tendo como dito acima, o trabalho como pano de fundo, sendo ainda fruto subjetivo das relações de trabalho; o nível de conhecimento e de representação mensurável nas manifestações culturais artístico-expressivas cuja persistência e pertinência histórica evidenciam a capacidade de subjetivação do homem. Filosófica e politicamente abordada como objeto de pesquisa cientifica restará a questão, em alguns raciocínios comprovadamente consolidada - assim, permanece como questão ou como metafísica insolúvel e assente? 


\section{2 - Das proposições metodológicas}

O trabalho nunca para. Partindo destas condutas apresentadas anteriormente: desejo (vontade de potência), deslocamento e procura/sentido da relação material, não temos condições históricas para afirmar que em algum momento em que o trabalho, atividade que situa a natureza humana nesta relação tenha cessado. Observamos sim clara e tragicamente o processo de alienação do trabalho desde a gênese, crescimento e intensificação. Postulando assim, não nos conduzimos adiante da constatação de um fato histórico. Mas, quando mudamos o ponto de vista, de uma panorâmica externa para a realidade pela qual estamos plenamente imbricados, nesta imanência do trabalho e, conseqüentemente até afetados por aquele processo de alienação, não podemos desconsiderar a pertinência do método nesta relação. Não é que haja, de forma específica, um método para cada atividade do homem, mas a atividade se nos apresenta inclusive como uma metodologia em seu desenvolvimento, enquanto orienta para uma metodologia de abordagens ou de análise para o caso de epistemologia. Por isso consideramos o método uma fundamentação filosófica e, por conseguinte é também político. Por isso também estamos seguros de que os momentos decisórios da história têm seus tortuosos meandros desenhados por ideologias políticas. Somos obrigados a admitir que, vivemos em sociedades cujos fins são decorrências dessas ideologias. De acordo com estas ideologias, mais correspondente as ocidentais, aprendemos bem a evitar o conflito em nome de uma paz e de harmonia social e nos conformar com o slogan freqüente: isso aí é isso aí mesmo. Decisões políticas exigem coragem. $\mathrm{O}$ mesmo deve funcionar para a escolha do método. Muitas vezes o remédio é amargo, mas sem dúvida a definição de uma postura política. O método contrapondo à lógica formal pela qual se tenta conformar o mundo em uma cena estática e metafísica da ordem

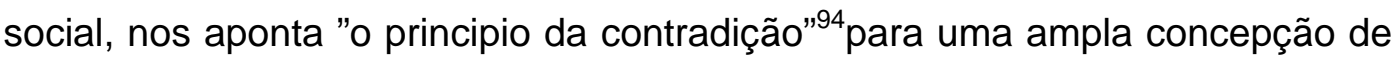
homem no mundo. Talvez por este motivo o método dialético pareça ao primeiro contato, aos desavisados um caminho espinhoso. Contudo é o método que nos permite adentrar as esferas da realidade e de que modo poderemos agir ou atuar dentro delas conhecendo-as intrínseca e extrinsecamente. $\mathrm{Na}$

\footnotetext{
${ }^{94}$ FERREIRA, Op. cit., p. 49
} 
obra "Alternativas Metodológicas para a Produção Cientifica" de Maria Nazareth Ferreira (2006) encontramos sem dúvida a porta de acesso ao reconhecimento da importância de se estabelecer metodologias adequadas quando queremos descortinar o caminho em meio às contradições, evitando assim atoleiros conceituais e, ao mesmo tempo uma justificativa incontestável para adoção da dialética como a maior premissa. Nossos primeiros passos dados visando alguma produção de conhecimento neste campo assumido estão direcionados para a pesquisa de uma política que possa evoluir para 0 restabelecimento do sentido da propriedade nas relações humanas, já desenvolvido anteriormente. Já pela complexidade percebemos que as doutrinas ou orientações que isolam sujeito e objeto, são deficitárias em alcance e, por isto mesmo, superadas pela fenomenologia, compreendendo o fenômeno segundo Gramsci como as

[...] qualidades que o homem distinguiu em conseqüência dos seus interesses práticos (a construção da sua vida econômica) e dos interesses científicos, isto é, da necessidade de encontrar uma ordem no mundo e de descrever e classificar as coisas [...] o que nós conhecemos nas coisas não é senão nós mesmos, as nossas necessidades e os nossos interesses, isto é, que os nossos conhecimentos são superestruturas (ou filosofias não definitivas) [...] não no sentido metafísico de "noumeno" [...] mas no sentido concreto de uma "relativa ignorância" da realidade, de qualquer coisa ainda desconhecido que, porém, poderá ser conhecido um $\operatorname{dia}[\ldots] .{ }^{95}$

Preliminarmente, objetivamos estabelecer parâmetros sobre os quais se pretende desenvolver os questionamentos. É preciso que se tenha em mente, do que nos aponta o enunciado acima, que conhecimento como superestruturas, não pode nem deve ser escalonado simplesmente como uma faculdade dentro daquelas atividades humanas. Como superestruturas 0 conhecimento compreende "[...] duas esferas essenciais: a sociedade política, que agrupa o aparelho de Estado, e a da sociedade civil [...]." ${ }^{96}$ Considerando que "o método é ao mesmo tempo uno e múltiplo, mostra que o processo de conhecimento só se eleva ao degrau mais alto quando admite a

\footnotetext{
${ }^{95}$ GRAMSCI, Op. cit., p. 54

${ }^{96}$ PORTELLI, Op. cit., p. 19
} 
contradição" 97 devemos adotar desde já, pelo que de se aponta como grau complexidade, posturas mais severas e atitudes mais rigorosas. Cabem neste ponto as indagações paradoxais entre o poder e o conhecimento: tem o poder quem conhece; ou, é quem conhece que tem o poder? Será sempre oportuno trazer em paralelo estas questões, uma vez a busca é por definir as filosofias que servirão as transformações necessárias e quem as revela.

Portanto, faz-se necessário apresentar sumariamente certa distinção entre duas correntes analíticas importantes. Tendo-as em mente, contribuíram, certamente, justificando e melhor definindo o caminho a ser trilhado. Em primeiro lugar, observam-se as limitações do modelo estruturalista, em cuja metodologia cientifica o termo - estrutura - deve servir convencionalmente ao conhecimento da sociedade, pois este requer instrumentos idôneos, um "modelo analítico com limites bem precisos e de identidade própria.""

O objeto do conhecimento do modelo estruturalista são as relações invisíveis; enquanto se observa uma realidade, esta mesma encobre à percepção imediata de certos componentes que atuam de forma a modelar as ações. A própria manifestação fenomênica oculta à condição essencial do real. Assim postulado, duas perspectiva são indicadas para questionamentos fundamentais. Inicialmente,

[...] a análise dos sistemas de parentesco e a estrutura dos mitos e lendas que existem em todo tipo de comunidade. A estrutura dos mitos e lendas atua, dentro desta linha metodológica, como aglutinador e organizador da comunidade. O sistema de parentesco pode mostrar como operam as relações formais; enquanto o mito dá a verdadeira fundamentação da dinâmica social em sua profunda causalidade. ${ }^{99}$

Podemos observar na primeira orientação à metafísica, qualquer coisa com intenções próprias, externa ao indivíduo, mas concernente a consciência humana; na segunda, a própria ordem biológica de reprodução atuando sobre as relações humanas. Vale destacar que ambas as perspectivas analíticas não determinam um objeto de forma contundente, mas intencionam fundamentar 0 conhecimento (da sociedade) a partir de interposto um sistema estrutural de ordem antropológica elementar. Neste sentido um elemento pressupõe a

\footnotetext{
${ }^{97}$ FERREIRA, Op. cit., p. 115

98 Ibid., p. 86

99 lbid., p. 87
} 
existência de outro elemento, tanto no que se refere ao cotidiano quanto aos rituais. Outro ponto a se analisar a partir do enunciado é que estes caminhos também se desdobram, divergindo-se em esferas de atuação. Por uma via se consideram as relações sociais humanas, e por outra, estas relações estão submetidas a uma estrutura subjetiva que parece desenhar ou conduzir (de cima) as atitudes dos indivíduos ou grupos.

Em suma, a crítica ao modelo estruturalista se dirige a sua

[...] tendência de construir uma totalidade analítica autosuficiente, submetida a leis próprias e operativas, onde o pensamento legisla sobre os limites do conhecimento "possível" através de uma imposição formal na qual submete a realidade. $^{100}$

O que vale dizer que, as significações e a essencialidade para obtenção do conhecimento são determinadas externamente, do ponto de vista do pesquisador.

Enquanto para o Estruturalismo o sistema das relações estabelece que a existência de um elemento pressuponha a existência de outro, na teoria funcionalista cada ator tem sua função, a qual exerce delimitando a ação de outro ator e, nenhuma das ações pode ser conflitante no sistema social. Um conjunto de normas deve conduzir tal equilíbrio. $O$ conceito se estabelece a partir da relação entre estrutura e função, ou seja, o grau de integração que "as partes mostram em sua relação dinâmica com o todo." ${ }^{101}$ A partir desta concepção, entendemos que um indivíduo determine seus papeis ordinários (padre, professor, policial; vai ao supermercado, ao banco; trabalha e se diverte etc.) imaginando assim cumprir sua função social. Dentro desta metodologia, se assim se pode resumir, aquilo que não é funcional deve ser desconsiderado como essencial para a análise cientifica. Neste sentido a crítica recai sobre as proposições teórico-metodológicas que admitem; em primeiro lugar que toda sociedade seja como uma "rede", com papeis e posições definidas, onde as instituições se alinhem e interajam em direção ao equilíbrio e ao progresso; em

\footnotetext{
${ }^{100}$ Ibid., p. 88

${ }^{101}$ Ibid., p. 93
} 
segundo, um "modelo" teórico cuja "estrutura conceitual analítica se baseie em critérios normativos e funcionais", "[...] não admitem a possibilidade de um salto qualitativo dentro do sistema: apenas seu fortalecimento ou destruição."102

Tecidas as críticas a estes modelos analíticos, passemos a apontar as propriedades da proposta teórico-metodologica que aqui se pretende adotar.

Divergente das metodologias anteriormente analisadas, que mantinham 0 objeto estático e distante do sujeito e, também desconsideram a historicidade do fato social, o marxismo como unidade metodológica pressupõe inicialmente o sentido de transformação da sociedade, observando-se seu objeto de conhecimento: "a predição da ação humana."103 [grifo da autora]

Segundo o Materialismo Dialético, vigora uma articulação entre as ações de forma positiva ou negativa, mas compreendidas dentro de totalidades produtivas. "Com efeito, se o trabalho é a mediação inevitável do homem com o meio, é em torno dele e de como se realiza a sua apropriação que deve-se encontrar a relação conflitiva original." ${ }^{104}$ também o trabalho não pode se resumir a função social puramente, pois compreende as relações humanas e materiais como um todo.

Ainda como assegura Ferreira (2006), a ideologia nas sociedades modernas tem servido para que prevaleça um sistema de reflexões práticas isoladas, ou, o conhecimento fragmentário ofuscando a visão sobre uma articulação harmônica nas atividades humanas, por mais dispares que pareçam ser. Continuando nesta linha de pensamento a função do método deve ser o de revelar as contradições no fenômeno. E, é a partir desse postulado que a metodologia aqui aplicada pretende confrontar a ilusão de uma ideológica que homogeneíza o pensamento e a percepção, por hora pesando enquanto cultura de valor (filisteísmo segundo Hanna Arendt, $1972^{105}$ ), imposta externamente sobre a ordenação social, com a ideologia das classes subalternas formada, pois nas relações de trabalho como fator de interação entre o homem e o meio objetivo:

\footnotetext{
102 Ibid., p. 94, passim

${ }^{103}$ lbid., p. 98

104 lbid., p. 99

${ }^{105}$ ARENDT, Op. cit., p. 253
} 
A "ideologia" foi um aspecto do "sensorialismo", ou seja, do materialismo francês do século XVIII. Sua significação original era a de "ciência das idéias" e, já que a análise era o único método reconhecido e aplicado pela ciência, significava "análise das idéias", isto é, "pesquisa da origem das idéias". As idéias deveriam ser decompostas em seus "elementos" originários, e estes não poderiam ser senão as "sensações": as idéias derivam das sensações. Mas o sensorialismo podia associar-se sem muita dificuldade com a fé religiosa, com as crenças mais extremadas na "potência do Espírito" e nos seus "destinos imortais; [...]. ${ }^{106}$

Pelo exposto, não é difícil perceber que as concepções sensoriais e, além disso, associada à fé religiosa como fonte para as idéias não era outra coisa senão um indicativo da atividade científica em função de brilhantismos fantásticos da imaginação do cientista, sendo este personalidade destacável:

A maneira pela qual o conceito de Ideologia como "ciência das idéias", como "análise sobre a origem das idéias", passou a significar um determinado "sistema de idéias" deve ser examinado historicamente, já que logicamente [grifos do autor] o processo é fácil de ser analisado e compreendido.

[...] O próprio significado que o termo "ideologia" assumiu na filosofia da práxis contém implìcitamente um juízo de desvalor, o qual exclui que para os seus fundadores a origem das idéias devesse ser buscada nas sensações e portanto, em última análise, na fisiologia: esta mesma "ideologia" deve ser analisada històricamente, segundo a filosofia da práxis, como uma superestrutura.[... $]^{107}$

Assim, continuando com a reflexão de Gramsci (1966) entendemos que o conceito de ideologia deve ser buscado dentro dos processos históricos. Assim como o conhecimento e o trabalho, a ideologia segundo a filosofia da práxis, também a assimila como superestrutura, isto é, compreende a sociedade civil e a sociedade política. Contudo, sua maior complexidade corresponde à implicação de um juízo de desvalor mediante o qual cai por terra a autoridade do cientista ou do pesquisador sobre o objeto e suas determinações. Podemos concluir que este juízo inclusive contrapõe criticamente a estrutura conceitual funcionalista, visto que a ideologia deixa de estar submetida à análise cientifica, conservando-se como parte do núcleo da filosofia historicista:

\footnotetext{
${ }^{106}$ GRAMSCI, Op. cit., p.61, passim

${ }^{107}$ Ibid., p. 61
} 
Um elemento de erro na consideração sobre o valor das ideologias, ao que me parece, é devido ao fato (fato que, ademais não é casual) de que se dê o nome de ideologia tanto à superestrutura necessária de uma determinada estrutura, como às elucubrações arbitrárias de determinados indivíduos. O sentido pejorativo da palavra tornou-se exclusivo, o que modificou e desnaturou a análise teórica do conceito de ideologia. O processo deste erro pode ser facilmente reconstruído: 1) identifica-se a ideologia como sendo distinta da estrutura e afirma-se que não são as ideologias que modificam a estrutura, mas sim vice-versa; 2) afirma-se que uma determinada solução política é "ideológica", isto é, insuficiente para modificar a estrutura, mesmo que acredite poder modificá-la; afirma-se que é inútil, estúpida, etc.; 3) passa-se a afirmar que toda ideologia é "pura" aparência, inútil, estúpida, etc.[...] ${ }^{108}$

\section{Entendemos que pelos erros apontados a partir do momento que o termo e} tomado pejorativamente, a ideologia se confunde com alguma coisa que se pode tomar por empréstimo de um sistema alheio. Equivoco que certamente passou a estabelecer uma ordem hierárquica a respeito ou do nível de verdades estabelecidas por determinada teoria ou do desenvolvimento da alta cultura das nações mais adiantadas:

É necessário, por conseguinte, distinguir entre ideologias historicamente orgânicas, isto é, que são necessárias à uma determinada estrutura, e ideologias arbitrárias, racionalistas, "desejadas". Na medida em que são historicamente necessárias, as ideologias têm uma validade "psicológica": elas "organizam" as massas humanas, formam o terreno sobre o qual os homens se movimentam, adquirem consciência de sua posição, lutam, etc. $\mathrm{Na}$ medida em que são "arbitrárias", elas não criam senão "movimentos" individuais, polêmicas, etc. (nem mesmo estas são completamente inúteis, já que funcionam como erro que se contrapõe à verdade e a afirma).,"109

Distinguir a implicação orgânica e histórica da ideologia corresponde também a se examinar a qual nível de profundidade ela se enraíza no funcionamento da sociedade, para saber o quanto ela está ligada aos princípios de luta e de transformação do ambiente. Neste sentido, é possível se admitir que: 1) uma ideologia tomada por empréstimo ou imposta arbitrariamente pode se

\footnotetext{
${ }^{108}$ Ibid., p. 62
}

${ }^{109}$ Id., p.62 
aprofundar na estrutura social determinando o modelo de funcionamento ou pode permanecer na superfície da percepção dos indivíduos se tornando optativa - neste caso para o grupo, tanto profunda como superficial ela nunca será própria e nem será assumidamente histórica; 2) sendo, todavia própria poderá ser reconhecida e divulgada pela superestrutura ou pelo sistema de cultura. Mesmo neste caso ainda poderá ser profunda ou superficial. Analisamos que ultimamente tornou-se problemática a discussão da ideologia sem que se depare com confrontos político-partidários. Este tipo de confronto dificulta o reconhecimento e a identificação da ideologia pelas massas.

Recordar a freqüente afirmação de Marx sobre a "solidez das crenças populares" como elemento necessário de uma determinada situação. Ele diz mais ou menos isto: "quando esta maneira de conceber tiver a força das crenças populares", etc. Outra afirmação de Marx é a de que uma persuasão popular tem, na maioria dos casos, a mesma energia de uma força material (ou algo semelhante), o que é muito significativo. A análise destas afirmações, creio, conduz ao fortalecimento da concepção de "bloco histórico", no qual, justamente, as forças materiais são o conteúdo e as ideologias são a forma - sendo que esta distinção entre forma e conteúdo é puramente didática, já que as forças materiais não seriam historicamente concebíveis sem forma e as ideologias seriam fantasias individuais sem as forças materiais. " 110

Quando nos referimos a um núcleo da filosofia historicista pretendemos enfatizar que este núcleo se compõe da ideologia e das forças materiais. Assim, quando refletimos sobre as relações de trabalho calculamos superados em muitas vezes a concepção de trabalho como subsistência, bem como equação hora/trabalho/consumo. O trabalho aqui, com já afirmado acima, é o elemento que liga o homem ao meio, mas confere também seu poder de deslocamento dentro da totalidade.

Entendemos que somente pelo método dialético abarcamos as transformações reais nas relações materiais pela lente da dualidade. Com a dialética materialista fundada por Marx e Engels ajustamos o foco eliminando as imperfeições através da contradição; o mundo está em constante movimento

${ }^{110}$ lbid., p. 63 
e as coisas estão em relação recíproca; ou seja: nenhum fenômeno da natureza pode ser compreendido isoladamente. Daí o conceito de totalidade, ser importante para entender a visão materialista da sociedade. Assim, à visão metafísica do mundo, os marxistas contrapõem à dialética “111. Portanto só há pertinência em qualquer aporte teórico às ciências humanas se analisadas do ponto de vista desta totalidade ou das relações materiais da sociedade. Uma das grandes contradições que encontraremos identifica-se entre o senso de propriedade e de posse. Quando tomamos por objeto manifestações culturais próprias das classes subalternas, mesmo que as encontremos em estado de definhamento ou de completa subordinação ao capital, em suas origens constatamos este senso de propriedade em contraposição ao de posse. Ao tomarmos a festa como ambiente apropriado para esta manifestações, identificamos também a reciprocidade entre ambas; e no entanto ninguém pode possuir a festa, ninguém é dono de uma forma de manifestação só há relação de propriedade recíprocas. Quando ampliamos a projeção destas manifestações para as relações materiais, esta reciprocidade vai a relação de produção e neste ponto muito do que tem valor não tem preço. Muito do que se pode comprar não se pode possuir: como as subjetividades do mundo trabalho. Segundo uma visão liberal, festa (popular) e trabalho são momentos estanques; apesar de que a festa é também um empreendimento e que muitos trabalhadores são empregados para a sua realização, ela é ainda, como contexto de férias ou de final de semana, um momento de laser e de êxtase que pode ser adquirido como pacote turístico compensador do estresse semanal devido a carga de trabalho. Entendida como subjetividade do trabalho a festa e suas manifestações espontâneas compreendem um ápice dentro de um ciclo, um momento de fixação catártica; fixação esta que para Gramsci é "o ponto de partida de toda filosofia da práxis"112, a festa, podemos ousar, se traduz assim em conhecimento ou expressão da concepção de homem no mundo e propriedade para a sua elevação à moral.

Voltamos, porém a questão do reconhecimento da importância do método a partir das relações materiais; segundo

\footnotetext{
${ }^{111}$ FERREIRA, Op.cit., p. 50

${ }^{112}$ GRAMSCI, Op. cit., p. 53
} 
[...] o materialismo, o movimento é propriedade [grifo nosso] fundamental da matéria e existe independentemente da consciência. A matéria é um dado primário e é a fonte da consciência; a consciência é um da do secundário, derivado, pois é reflexo da matéria. O materialismo dialético parte da consideração de que os fenômenos materiais são processos. ${ }^{113}$

Enquanto processos, a totalidade que engloba contradição e movimento, organicamente não há o que esteja a mais nem o que falte; uma vírgula em um poema, as notas ou mesmo o silêncio em uma música, na pintura que traz toda a composição para o bidimensional, há planos segundo a visão, mas dificilmente conseguimos estabelecer uma hierarquia de valores que desclassifique um elemento por ínfimo e afastado que esteja na perspectiva; no caso de um impulso criativo que desfalque ou sobrecarregue a obra, ainda assim isto serviria ao exercício da crítica. Ampliada a história da sociedade, segundo mentalidades individuais e arbitrárias há a omissão e também o turvamento da visão e há a distinção por classe, mas como processo não há algo do contexto atual que possa ser considerado como fora da história. Assim, dentro da metodologia um grande passo a ser dado é a contextualização do sujeito/objeto na análise marxista "conhecida como qualidade em sistema"[grifo da autora]. Segundo Nazareth (2006) uma contribuição da teoria de Marx a ciência:

Em certo sentido, cada qualidade possui seu sistema, pois a qualidade sempre expressa uma nova determinação específica ou genérica. Mas neste caso não se trata das relações em sistemas simples, que resolvem, por exemplo, o fato de que o cavalo pertença à espécie "cavalos", a mesa, à espécie das "mesas"; mas o que expressa a própria essência do princípio em sistema são as propriedades [grifo nosso] integrais do todo, irredutíveis às propriedades [grifo nosso] de suas partes ou elementos. A diferença das duas primeiras determinações qualitativas - que estão sempre presentes nos fenômenos materiais - seja como qualidade própria da matéria, seja como forma específica - estas últimas são qualidades de conjunto, ou integrais. Devido a isto, nos objetos e fenômenos concretos não estão materializadas com precisão e rigidez e figuram neles somente como um sintoma geral de sistema ou como "parte proporcional" do todo. Do ponto de vista comum, as qualidades em sistema não podem ser apreciadas através da simples

${ }^{113}$ FERREIRA, Op. cit., p. 55 
observação, mas somente através da análise cientifica e, além disso, de uma análise que abarque o sistema em sua totalidade. ${ }^{114}$

Concebida a relação entre qualidade e a totalidade, vale destacar o que nesta relação se expressa como propriedades integrais. Para que adentremos com nossa investigação neste campo de análise temos que perguntar inclusive, quais as "qualidades sociais dos objetos"115(?) São certamente inúmeras as possibilidades de configuração destas qualidades pelos aspectos sócio-político, sócio-econômicos e culturais. Antes de um aprofundamento sobre as qualidades sociais identificáveis em manifestações culturais próprias, vale destacar a respeito mais especificamente da modernidade tardia ${ }^{116}$ na América Latina, assim como em outras ex-colônias do norte global. Há uma distância histórica menor com relação a um estágio anterior à formação dos Estadosnação, pois assistimos aos esforços para se alcançar personalidade competitiva, individual ou coletiva (MERCOSUL) no sistema de comércio globalizado; e, do ponto de vista sócio-cultural há atualmente uma espécie de revisão dos processos civilizatórios nos quais muitos aspectos de uma relação primitiva de propriedade (línguas, éticas, costumes etc.) foram simplesmente aniquilados em nome de uma cultura européia mais elevada. Podemos observar claramente este quadro, num amplo antiamericanismo, nas reivindicações por reconhecimento das riquezas estratégicas nacionais, na demarcação de terras dos povos originários e quilombolas e em governos mais representativos das classes até o momento, desfavorecidas. Paradoxalmente temos que admitir que, com relação aos efeitos colaterais das crises globais, estamos todos plenamente atualizados. Daqui destacamos mais uma possibilidade de qualificação social daqueles objetos. Esta personalidade armase de uma estrutura psico-social interna básica que the permite as relações e os contatos fronteiriços onde se dão os estados de crise. O conflito volta-se para a estrutura básica de cada lado abalando-a e ao mesmo tempo exigindoIhe resistência, podendo se traduzir em auto-afirmação. Com base nesta argumentação entendemos que a cultura é a principal substância desta

\footnotetext{
${ }^{114}$ Ibid., pp.56-57

${ }^{115}$ lbid., p. 57

${ }^{116}$ HALL, Op. cit., p. 14
} 
estrutura. Gramsci (1966) ao tratar da filosofia especulativa faz analogia com o desenvolvimento do Estado, por sua passagem da fase econômico-corporativa à fase hegemônica. Também observa "que toda época chamada de decadência (na qual ocorre uma desagregação do velho mundo) caracteriza-se por um pensamento refinado e altamente "especulativo." ${ }^{117} \mathrm{Em}$ se tratando de uma metodologia que nos ensina a tatear pelas contradições, esta análise, nos remete diretamente ao contexto atual de crise econômico-financeira global (gestada no sistema econômico norte-americano), que exemplifica a exacerbação na aplicação da teoria do movimento browniano, desenvolvida por Einstein prenunciando já os estudos da física quântica, e que trata de oscilações e probabilidades no movimento caótico do átomo, aplicada aos movimentos do mercado de ações - especulações mobiliárias. Para equilibrar os orçamentos internos os Estados-nação deve-se injetar grandes somas no setor financeiro-empresarial, incentivar o crédito e intensificar o consumo. De um lado ilustramos um fato histórico e por outro reafirmamos nossa funçãomassa na ordem capitalista - consumir.

Retomando a questão da cultura própria. Não queremos, contudo (re)inventariar os culturalismos nacionais, pois não nos interessa quantificar as formas pelas quais se metamorfoseiam e diversificam-se as aparências, mas identificar e dar ênfase as reais transformações qualitativas: as relações pedagógicas, as relações de propriedade e reciprocidade segundo o marxismo e a postura ético-política segundo Antonio Gramsci - as relações de produção. Também não nos esquecemos de que o capitalismo como modo de produção também se apropria deste produto (trabalho) imaterial, mas coloca-o secundariamente na ordem de consumo, na primeira fila vem os que correspondem imediatamente à demanda e podem ser reproduzidos em massa. Assim, como outras teorias não podemos nos esquivar do confronto entre cultura própria e cultura de massa, submetendo-as ao nosso método de análise. Não falamos de duas culturas distintas e sim de que, como sabemos todos e subsumimos, há uma divisão de classes no acesso e na produção cultural. Divisão esta gerada pela cultura de valor com já anunciamos. Acreditamos que quando em uma manifestação não está incutida a idéia de

${ }^{117}$ GRAMSCl, Op. cit., pp. 56-57 
preço (cachê), já encontramos superado o ideal mercantilista. Mas isto não é um ato de coragem em se trabalhar de graça, o que nos desperta a atenção e de ser esta postura um fato histórico. Também não se trata de um hobby das horas livres, pois está impregnado da dimensão do simbólico, ou seja, do que é oferecido e do que é recebido - os aspectos da dádiva. Não adentraremos a questão da metafísica considerando, conforme o pensamento de Gramsci (1966)

[...] que toda cultura tem o seu momento especulativo e religioso, que coincide com o período de completa hegemonia do grupo social do qual é expressão, e talvez coincida precisamente com o momento no qual a hegemonia real se desagrega na base [...]. ${ }^{118}$

Permaneceremos analisando do ponto de vista das relações materiais, reafirmando estas manifestações como imprescindíveis ao contexto das relações de trabalho. Observemos ao que a pesquisadora Nazareth aponta como sendo uma grande inversão: o homem que devia ser senhor soberano de seu produto, passa a ser comandado e dirigido por aquilo que produziu. "Não é possível esquecer a função humanizadora do trabalho [...]" ${ }^{119}$. Metodologicamente, devemos nos voltar então para as contradições nesta esfera. Estamos falando do trabalho próprio; poderíamos tê-lo enquanto trabalho; como propriedade em contraposição a idéia de trabalho alienado, como mercadoria, mas queremos enfatizá-lo enquanto elemento estruturador das inter-relações sociais através de suas subjetividades. Não somente física psico-sensorial, mecânica do individuo, mas uma gama incomensurável de compreensões, condutas e a coordenação do espaço/tempo ligadas às atividades criadoras do homem. Para entendermos melhor, a concepção de subjetividades do trabalho, tomemos por base a idéia de inserção da consciência na realidade. Se partirmos do pressuposto de que esta inserção inicia-se, grosso modo, através da técnica e posteriormente passa á ciência pela atitude dos intelectuais, e se concebemos o método como fundamentação filosófica, socialmente o método é um modo de proceder que na práxis colabora na organização da vida dentro e em torno do modo de produção. Há fundamentações filosóficas e metodológicas essenciais dentro das relações de

\footnotetext{
${ }^{118}$ lbid., p. 56

${ }^{119}$ FERREIRA, Op. cit., p. 72
} 
produção. Podemos então afirmar que ao abordarmos a "cultura" verificamos que na maior parte dos casos trata-se de visões externas que externas permanecem enquanto levantamentos e postulações de fundo, já feitas não se consolidam em projeto, em práxis, enquanto não retornam à cultura que lhe serviu de objeto. Não queremos afirmar com isso, que o método observado em uma conduta de interação social, ou o modo como as pessoas se envolvem em grupos de interesses afins, serviria da mesma forma à pesquisa. Porém o método cria seus protótipos distribuindo dinâmicas na organização da sociedade. O método tem aí seu potencial ideológico, o método é político. Por isto mesmo para indagarmos entre estas dinâmicas, sobre aquela correspondente a função orgânica do intelectual terá de ser através de uma metodologia política filosoficamente praxística. Enquanto isto não se dá permanecem as problemáticas, hora mais, hora menos polemizadas para que não percam seu status de problema, multidisciplinarmente conceituados em metas-linguagem diferentes por diversos ângulos. Queremos crer que esta letargia da ação político/midiática do intelectual para inserir-se na consciência da realidade, seja um problema metodológico que torna cada vez mais distante uma concepção do trabalho-próprio, quando o trabalho intelectual não transcende a produção acadêmica e vai ao mundo das atividades. Por isso perguntamos quais seriam os mecanismos que permitiriam maior articulação desta produção no campo de sua demanda? Para Marx, conforme apresenta Nazareth Ferreira (2006), "a noção de modelo pode ser considerada o núcleo, o ponto de partida para entrar na discussão da problemática metodológica nas ciências sociais dos positivistas." Quando aplicamos o substantivo articulação aferimos diretamente a "noção de estrutura" - a qualidade em sistema na qual se coadunam o pensar e o agir. "Esta relação entre o "todo e as partes" define com clareza a relação entre o sujeito e o objeto como uma relação entre estruturas conceituais (o sujeito) e reais (o objeto)." ${ }^{120}$ Com base neste postulado podemos reconhecer que tem sido replicado um modelo referencial na práxis acadêmica que não leva em conta as estruturas conceituais e reais. Por isso se tratar de um problema do método que entendemos compreender três momentos fundamentais a abordagem, a análise (das contradições) e a

\footnotetext{
${ }^{120}$ Ibid., p. 81
} 
práxis - tese, antítese e síntese. Não há entre estes momentos qualquer hierarquia de valor e tampouco uma ordem que determine onde cessa a teoria e onde se inicia a prática:

Assim, o predomínio da estrutura subjetiva sobre a objetiva, ou o predomínio inverso, ou ainda, o equilíbrio sem predomínio, entre o conceitual subjetivo e o real objetivo, é parte da discussão entre os diferentes "modelos de conhecimento" da realidade, e referem-se a premissas metodológicas diferenciadas. O modelo contém um enunciado teórico ideológico que se expressa numa proposição metodológica para referir-se à realidade, na ação de conhecê-la. É a maneira de explicar a historicidade das alternativas de conhecimento, de como estas alternativas se configuram em 'modelos' que diferem em seu compromisso com o real, na medida em que diferem na maneira de "pensar o real". 121

Considerando que os desvios possam ser detectados e medidos a partir da observação das práticas sociais, sejam estas de explicitação da cultura ou mesmo em qualquer espécie de degradação social; devemos reconhecer que a universalidade do método significa superar qualquer visão fragmentária que não traga em seu bojo a concepção de um modelo global cujo núcleo teórico para Marx, elucidado por Ferreira (2006) corresponde

[...] a constituição de uma articulação [grifo nosso] de categorias como "Modo de Produção", "Formação cão Econômico-social" ou "Bloco Histórico", serve à compreensão da sociedade em cada momento histórico visto em toda a sua complexidade e fundamentalmente, no sentido de definir estratégias para sua transformação. ${ }^{122}$

Não somente constatamos, enquanto desvios, o método de abordagem (tese resgatar - conservar) como também na assimilação do modelo implícito naquelas formas de manifestação (antítese - o ideal de resistência). Não há, portanto, se assim é cabível, observância rigorosa das contradições, não há continuidade praxística em síntese. Não há deslocamento se não há uma concepção de articulação entre os indivíduos e entre as categorias na divisão social do trabalho. Finalmente não há possibilidade de se predizer a ação humana:

\footnotetext{
${ }^{121}$ lbid., pp. 81-82

122 lbid., p. 98
} 
Para o Materialismo Dialético o entendimento de toda ação se define como a conscientização da totalidade que está presente em uma prática, por limitada e acidental que esta possa ser. É precisamente esta prática limitada, que, para ser compreendida deve ser assumida em seus limites, pelo fato de estar articulada com outras praticas, que se relacionam positiva ou negativamente. Assim, a reflexão de um sujeito sobre o significado da articulação de suas próprias práticas implica a reflexão sobre as práticas de outros sujeitos que estão envolvidos no exercício de suas práticas através de diferentes níveis de ação em um determinado contexto social. ${ }^{123}$

Dentro das proposições metodológicas aqui pretendidas, a abordagem se dá a partir da historicidade daquelas determinadas práticas sociais, pois e o modelo global observado no que se configura como articulação entre explicitações culturais-próprias e o trabalho-próprio. Ambos os procedimentos "se articulam harmônica e contraditoriamente em torno da prática produtiva [...]". Como afirmado na sessão anterior, nosso pano de fundo é a esfera do trabalho; "[...] se o trabalho é a mediação inevitável do homem com o meio, é em torno dele e de como se realiza a sua apropriação que deve-se encontrar a relação conflitiva original." ${ }^{\prime 24}$ A este pensamento queremos acrescentar, enfatizando ao conjunto das subjetividades oriundas deste momento de apropriação do mundo do trabalho. É por este viés que escolhemos conduzir nossa investigação para que tenhamos respostas às indagações a respeito de quais fios foram rompidos na trama desta articulação e se podemos reatá-los.

Como procedimento científico não pode se furtar a concepção de totalidade quando menciona mundo do trabalho, portanto são superadas as particularizações (salário, consumo, subsistência etc.), o todo irredutível às partes nos apresenta como unidade simbiótica entre trabalho e festa na ordenação social; festa nesta unidade corresponde às construções que não são propriamente obrigações daquela esfera, mas sim espontaneidade do cotidiano das relações de trabalho. Tanto esta espontaneidade quanto a objetividade daquelas relações são edificadoras da humanidade social de cada indivíduo conforme seu nível de participação nesta esfera - "há um nível de contradição fundamental que é aquele que se situa entre as Relações de

\footnotetext{
${ }^{123}$ lbid., pp. 98-99
}

124 lbid., p.99 
Produção e as Forças Produtivas: é fundamental por que é a estrutura mesma da constituição da sociedade, baseada na apropriação individual do produto social." Entendemos por este postulado que nas Relações de Produção estão previstos todas as circunstâncias históricas envolvidas naquele momento e, há certamente decorrências expressivas da cultura que estão igualmente amalgamadas com as Forças Produtivas nestas Relações, "o Materialismo Histórico apenas está indicando um "potencial" presente historicizado, sobre o qual estas contradições atuam decidindo a direção da mudança social, em termos qualitativos ou quantitativos e o tipo de maturação, e antagonismo que as mesmas alcançaram "no político"”." ${ }^{125}$ A este ponto cabe ressalvar a questão da apropriação ou da propriedade do individuo sobre o trabalho e as condições objetivas para o trabalho. É neste senso de propriedade, com já dito que abordamos as subjetividades edificantes. Porém no tratamento dos desvios que se apresentam em referência do trabalho com o consumo, resta indagar se haveriam e como se dariam as possibilidades de reconstituição deste senso político de propriedade em um mundo-mercado partilhado em propriedades privadas.

São, todavia as práticas e as contradições, examinadas nesta rede cuja trama se articula em uma dinâmica de interação que devem conduzir a formulação de aporte para um núcleo teórico, no sentido de ampliar a compreensão sobre os modos culturais, que têm no móbil das festas, e em tudo que as consubstancia, uma das portas de acesso a um "modo de produção", indicador histórico das atuais contingências sociais. Bem como permitirá abordagem a relação praxista entre sujeito e objeto. As festas têm sido até aqui, grosso modo, observadas como uma espécie de relaxamento entre atividades produtivas e hoje ainda mais como potencial atrativo para o turismo. Através de uma metodologia marxista será possível se verificar, nos modos produtivos refletidos neste espelho a relação concreto-abstrato, sendo que neste contexto de reconstrução do "real", igualmente se constata a relação do todo com as partes. Estas relações que projetam-se sobre o objeto de estudo em questão como amplitude das correlações entre trabalho e conhecimento sociais.

${ }^{125}$ Ibid., p. 105 
O encontro entre teoria e método deve se dar em um abraço fecundo. Devem ser (re)-divididas as responsabilidades. Acreditamos que o mapa para que as reconheçamos, nesta relação entre teoria e método esteja escrito nos sensos de propriedade e de reciprocidade. Segundo o modelo de formação básica, cujo fundo é funcionalista, colocado em prática em boa parcela das regiões do Brasil, os jovens fazem poucas experiências profundas nestes sensos. Portanto não podem se sentir responsáveis. Participarão da sociedade, obedientes ou subversivos ao sistema. Sem o que crescem orientados pela ordem diária de que o muito que do que não se pode pagar corresponde diretamente ao pouco do que se pode ter. Isto é, dificilmente carregarão uma consciência de que somos próprios de um ambiente social e ecológico, - da mesma forma que o apropriamos para o desenvolvimento da sociedade. 


\subsection{Impulso da utopia}

O desenvolvimento da sociedade não pode ser indeterminadamente compreendido como avanço no tempo e na tecnologia; avança de acordo com a aceleração dos eventos. Este desenvolvimento não corresponde especificamente ao movimento de começo meio e fim. Ao conceito de nação desenvolvida, não pode prevalecer o ideal de quem esteja financeira e tecnologicamente avançado. Muito menos que estes devam permanecer como ditadores da ordem universal.

Devido à dimensão dos desvios medidos por uma análise filosófica, no quadro atual do desenvolvimento humano, um impulso pode nascer, inclusive nas coisas, se couber o termo, impensáveis

[...] La utopía, toda utopía, proyecta los sueños y las esperanzas de los dominados; pero también de los que sin serlo se cuentan entre los humillados e ofendidos de este mundo. Es decir, de aquellos para quienes la explotación y la dominación, cualquiera que sea la forma de su existencia, son ofensivas y humillantes para el conjunto de los hombres e de las mujeres de la tierra.[... $]^{126}$

Quando pensamos, hoje, e perguntamos com base no sistema de crises instalado, qual das realidades vividas não são elas próprias pretensas utopias, ou parte delas? Quando projetamos os questionamentos para a realização da felicidade individual ou coletiva, pouco ou nada acrescentamos ao desenvolvimento da psicanálise e ao conceito de sociedade da satisfação, não restam dúvidas inclusive de que esta realização traga suas interfaces negativas e positivas. Podemos então, projetar à realização da paz, ressalvando, porém não devemos confundir paz com pasmaceira, ócio improdutivo, trabalho inútil e muito menos com a passividade. Pode se objetar se existe possibilidade de paz sem felicidade? E, se expressamos a questão de maneira inversa, - podemos obter felicidade sem paz? $O$ fato é de que podemos passar por esta vida sem se ter experimentado a felicidade ou a paz e que ambas nem sequer tenham sido necessárias, pois aprendemos que é mais do que possível se contentar com o que seja muito necessário; neste

\footnotetext{
${ }^{126}$ QUIJANO, Anibal. Estetica de La Utopia. Rio de Janeiro, C. e P., X (13 - 14). Jan - jun, 1991, pp.192-
} 193 
caso a energia deve ser proporcional à demanda; mas, também é possível se contentar com o pouco necessário, que, no entanto, nem por isto chega a ser inessencial. Não se trata do pouco da miséria, mas o bastante do necessário. Muitos, passam pela vida simplesmente trabalhando, dedicando suas horas de vigília à pesquisa, à filosofia, à arte etc.. Não queremos afirmar com isto que o prazer que se origina nas atividades lúdicas, de laser ou do relacionamento social humano sejam dispensáveis. Ao contrario, entendemos que a vida mediada em fenômenos e fatos sociais dentro das subjetividades das relações de trabalho é suficientemente plena quando o sujeito vê satisfeitas suas aspirações individuais e coletivas. Assim sendo a utopia é então algo que se pode projetar. Ou seja, é algo que se coloca à frente como horizonte, buscá-lo é o trabalho.

[...] eu me vali do espaço utópico ainda proporcionado pela universidade, que, a meu ver, deve permanecer como um local em que se investigam, discutem, e se refletem essas questões vitais. Tornar-se um local para a imposição ou solução de questões políticas e sociais seria eliminar a função da universidade e transformá-la num anexo de qualquer partido político que esteja no poder. ${ }^{127}$

Da declaração podemos ter a impressão de que soluções políticas e sociais não poderiam vir inclusive com a participação da universidade. Questionamos se a vida política da sociedade corresponde então somente à do partido? Não concordamos, no entanto com a imposição; muito menos com qualquer vinculação da universidade com interesses partidários. Entendemos também que a universidade nunca deva deixar de ser o espaço da reflexão. Difícil se torna aceitar que o conhecimento - resultado das investigações a que muitos chegaram - permaneça ali enclausurado. Não é cabível, sabemos, se divulgar o conhecimento através de alto-falantes instalados nas vias públicas. Contudo, o espaço do conhecimento não se limita às concessões vestibulares. $E$, em se tratando do desenvolvimento da pesquisa científica como já colocamos, não seria por acaso a própria escolha do método uma ação política? A resposta é única, pois o método deve compreender a predição da atividade humana, muito

${ }^{127}$ SAID, Edward W. Cultura e Imperialismo. São Paulo: Companhia das Letras, 1995, p. 28 
mais do que complementar a fase acadêmica do cidadão, angariando pontos para uma sociedade de classe cada vez mais ilustrada ${ }^{128}$. Portanto a universidade é que deve se deslocar para o ambiente das negociações políticas, não para impor soluções, mas para garantir que as articulações não percam o impulso da utopia. Reconhecemos, portanto, a predisposição do espaço utópico da universidade em levar conhecimento à massa.

O desejo em si é uma utopia que ao ser satisfeito deixa de ser desejo; também se desfaz enquanto utopia. O desejo não satisfeito se transforma na histeria que atualmente caracteriza o consumismo cultural nas sociedades. A produção de conhecimento ou a sua busca, no entanto realiza ao desejo sem extingui-lo, fazendo com que seja perene a utopia. Há um contraponto interessante entre, por exemplo, os desejos de possuir e o de construir. Podemos possuir sem ter propriedade - a posse se estabelece, a propriedade se dá, desenvolve-se. Permite-se predizer as possibilidades de apropriação, mas é quase impossível impô-las. Se, de acordo com a afirmativa anterior perguntarmos o que se faz quando é satisfeito o desejo de posse? E, como distribuir o desejo de posse no processo de construção e depois de cessado esse processo? Impulsionado pelos sensos de propriedade e de reciprocidade o desejo deve passar de individual para coletivo e ser uma vontade coletiva. Não queremos necessariamente focalizar uma contraposição entre os termos, nem tampouco selecionar entre as nuances do desejo, as ideais. Interessa-nos agora é como posicionamos a utopia quando as contradições se apresentam entre o trabalho como relação material e as subjetividades das relações de trabalho.

Assim como carregamos conosco a falsa ilusão de progresso da humanidade, a utopia não é um sonho irrealizável, inalcançável. Tratamo-la aqui por acreditarmos em sua faceta como impulso. É bastante evidente hoje, que a grande maioria das pessoas não participa ou não usufrui dos avanços tecnológicos de forma direta e mesmo indireta - acesso a ciência. É tamanha a velocidade com a qual avançam as tecnologias; e, por este motivo, em sua maior parte sequer teremos tempo para almejá-las, obtê-las e dominá-las. Porém não deixamos de acreditar que estes progressos são da humanidade, e,

${ }^{128}$ BAUMAN, Op. cit., p. 113 
da qual fazemos parte. Estamos sempre cientes de que, boa parte destes progressos não está realmente ao alcance de nossos parcos ganhos, porém constituem sim, os sonhos hipnóticos de consumo da massa. Por isso e, em oposição a esta condição, se faz necessário considerar a utopia de um horizonte que nos desperte do transe do conformismo. Vivemos acreditando cegamente na escala da caducidade do tempo. Que o que foi não tem volta e que é perda de tempo reconsiderar, da esfera da memória, métodos e técnicas passadas. Porém, as perguntas feitas não são exatamente sobre o aspecto qualitativo destas reconsiderações, mas, quanto irá custar; quanto se pode produzir e, quanto irá render. Um exemplo bastante evidente desta situação é a tendência de uma produção agrícola orgânica. Antes que as indústrias químicas passassem a lucrar com adubos e pesticidas, os produtores estavam sim, à mercê dos prejuízos "naturais" (climas e pragas), mas não deixava de existir uma produção, também havemos de considerar que não havia tanta dependência e subordinação aos grandes produtores; já existia agricultura familiar, apesar de que nas décadas de 1920 após a decadência da produção de café, havia já grandes contingentes populacionais nas cidades e havia grandes cidades; ainda assim as casas tinham seus quintais com pequenas culturas de subsistência. As cidades dividiam-se evolutivamente, em zonas urbanas, o centro; o subúrbio e as zonas rurais; cada espaço com suas características peculiares de relações de trabalho e de cotidiano. Atualmente esta divisão define espaços de produção e de consumo - o centro e a periferia.

Não podemos nos perder em saudosismos, mesmo por que perderíamos muito tempo até justificá-los. Mas quando examinamos as condições de vida atualmente, podemos constatar grandes contradições na organização da produção e do consumo e nas grandes demandas (alimento, moradias, segurança).

Vivemos lógicas ou vivemos teorias? As ultimas servem ora como amparo, ora na tentativa de aproximação explicativa das primeiras. As teorias confundem-se entre as subjetividades, abstrações que poderão dar diretriz ou interpretação à lógica. Porém, se não há teoria, ainda assim o que dá substância à lógica será algo de aleatório, múltiplo, efêmero, imediato, sem necessidade de reconhecimento ou de explicação, mas será o condutor do pensamento e do 
comportamento. Encontraremos muitos exemplos destas contradições postuladas ao conferirmos a situação climática do planeta (a lógica econômica e a lógica da auto-preservação), a situação da sociedade vivendo em grandes centros e grandes extensões periféricas (a lógica da sobrevivência e da individualização), e sobre o desenvolvimento humano (a lógica do progresso e da continuidade histórica é a lógica da inclusão ou exclusão). 
This document was created with Win2PDF available at http://www.win2pdf.com.

The unregistered version of Win2PDF is for evaluation or non-commercial use only.

This page will not be added after purchasing Win2PDF. 


\section{CAPÍTULO 2}

\section{CONFIGURANDO A RESISTÊNCIA.}

\section{1 - Resistência}

Já introduzimos neste trabalho uma abordagem ao aspecto mais semântico da questão da resistência, proposta em diversas abordagens para se pensar sobre as condições da cultura das classes subalternas. Aqui, tentaremos ampliar um pouco mais esta discussão, pois não é sem motivo que amiúde nos deparamos com a aplicação do termo. Desde tempos mais remotos, quando do embate de crenças e ideologias, como, por exemplo, quando inovações do pensamento ou científicas contrapunham a preceitos religiosos ou a determinações monárquicas, estas inovações sempre foram tratadas nos moldes da correção da época, com rigor e violência. Aconteceu assim com os filósofos (Aristóteles) e cientistas (Galileu) que contrariaram a Igreja. Assim também com povos que se rebelaram contra a escravidão e contra a colonização. Aqui, no entanto nosso foco recai sobre o que se tem chamado de resistência cultural. Não se trata evidentemente de algo separado destas circunstâncias mencionadas acima, mas, a resistência, da forma como é observada aqui é então mais 
significativa quando relacionada à afirmação da identidade cultural nacional. A princípio aproveitaremos das definições proposta por Edward W. Said (1995) para cultura que a princípio

[...] designa todas aquelas práticas, como as artes de descrição, comunicação e representação, que têm relativa autonomia perante os campos econômico, social e político e que amiúde existem sob formas estéticas, sendo o prazer um de seus principais objetivos. Incluem-se aí, naturalmente, tanto o saber popular sobre partes distantes do mundo quanto o conhecimento especializado de disciplinas como a etnografia, a historiografia, a filologia, a sociologia e a história literária. [...] a cultura é um conceito que inclui um elemento de elevação e refinamento, o reservatório do melhor de cada sociedade, no saber e no pensamento $[\ldots] .^{129}$

Desta abordagem inicial é preciso dar destaque ao que se refere à autonomia na relação da cultura com campos diversos como o social, o econômico e a política. Não que esta autonomia não possa ou não deva existir, mas não se pode desconsiderar que ambos os campos, inclusive a cultura têm de certa forma uma mesma gênese quando colocamos a visão acima das formas estéticas e do prazer enquanto finalidades. Concebendo esta gênese comum para a cultura assim como para aqueles outros campos, podemos admitir que a partir dela iniciam-se processos de experimentação e consolidação ou de experimentação e descarte; e ainda de descarte sem experimentação. Isto é, a cultura também se desenvolve corroborando com os sistemas social, econômico e político. Nos três casos a experimentação e uma componente central. È sociológica quando permite que alguma idéia chegue a consenso; diz respeito à economia quando se apropria da noção de quantidade, (escassa, suficiente ou excedente) e também é política, pois em todos os casos há necessidade de decisão. Por este prisma, podemos até certo ponto assentir que

[...] a cultura mitiga, se é que não neutraliza por completo, a devastação de uma vida urbana moderna, agressiva, mercantil, embrutecedora. A pessoa lê Dante ou Shakespeare para

${ }^{129}$ SAID, Op.cit., p. 12 
acompanhar o melhor do pensamento e do saber, e também para ver a si mesma, a seu povo, sua sociedade, suas tradições sob as melhores luzes. Com o tempo, a cultura vem a ser associada, muitas vezes de forma agressiva, à nação ou ao Estado; isso 'nos' diferencia “deles", quase sempre com algum grau de xenofobia. A cultura, neste sentido, é uma fonte de identidade, e, aliás, bastante combativa, como vemos em recentes "retornos" à cultura e à tradição. Esses 'retornos' acompanham códigos rigorosos de conduta intelectual e moral, que se opõem à permissividade associada a filosofias relativamente liberais como o multiculturalismo e o hibridismo. No antigo mundo colonial, esses "retornos" geravam vários fundamentalismos religiosos e nacionalistas. ${ }^{130}$

Contudo, torna-se necessário que se definam os percursos através dos quais as abordagens e os estudos, cujo objeto é a relação com a cultura, em muitos casos se encaminham para a apresentação da cultura às formas degradantes de dominação ou estão empenhadas em revelar as forças e os procedimentos sociais para a real autonomia. Desta definição começamos a adentrar a questão da resistência cultural, não somente como um permanecer e resistir ou a tentativa de auto-preservação, com base, até mesmo no que não conhecemos sobre a própria cultura; e, que daí, importamos aquilo é melhor nos outros ou ainda, tentamos resgatar da memória. Deste resgate não trataremos, mas importa colocar que esta é uma espécie de estratégia para se aumentar a barricada ou cavar mais profundamente as trincheiras com as quais tentamos nos proteger das forças opressoras. Entendemos que um saber popular, como está indicado no primeiro caso, pressupõe já a subsistência de uma concepção de homem no mundo. Mesmo que buscada em campos da metafísica, na falta de uma explicação cientificamente atestada, corresponde a um movimento próprio do ser no mundo. Não é uma justificativa, nem tampouco uma aceitação geral da existência, mas pelo fato de que esta existência é em si uma indagação, uma incógnita. Este saber popular significa, por se tratar de um saber, um ponto inicial para a superação do senso comum, que não é exatamente conhecimento, mas, lato sensu, uma forma de assentimento. Por isto as culturas subalternas além do aspecto científico que já tem sido revelado, é também o arcabouço de técnicas elementares (técnicas

\footnotetext{
${ }^{130}$ Ibid., pp. $12-13$
} 
agrícolas, construções com terra, etc.), isto é, são práticas construtivas que serviram e servem de base para muitos dos desenvolvimentos tecnológicos atuais. Com esta formulação tentamos situar a questão em um âmago mais profundo da consciência humana, contrapondo à idéia de resistência, intimamente associada à concepção institucionalizada de fomento à cultura. Fomentar a cultura corresponde diretamente a desenvolvimento sócio-cultural, ou seja, a formação ou elevação cultural de uma sociedade - mais cultura (mais cinema, mais livros, mais universidades, mais intercâmbios, mais acesso a informação etc.). Desta forma podemos considerar que todas as oportunidades que os indivíduos de uma sociedade têm de fruir, à qualquer fenômeno que se entenda como momento cultural está amparado nesta concepção; e, não necessariamente em uma proposta de reconduzir à prática cultural; ou, o saber popular à condição de pressupostos básicos para a autonomia da sociedade como um todo. Em outras palavras, é na cultura popular que se pode encontrar representada, uma parte essencial da natureza humana correspondente às subjetividades, onde estão mais especificamente as reservas criativas. Portanto, cultura é em si a própria resistência.

Não nos diz respeito, nem está em nossa alçada, qualquer censura a qualquer forma de expressão com a qual este ou aquele sujeito se identifique ou nela seja objeto de condicionamento. A questão se configura na falta de uma base que lhe sirva ao menos como senso crítico. Também, não faz sentido dizer que uma elevação cultural baseada em uma formação de alto-nível seria preferível á uma popular. O problema está em entendermos o popular como cultura inferior. Daí decorre o surgimento dos vários tipos de imperialismos (nacionais, empresariais, intelectuais), com suas formas de sobreposição (raças inferiores, países subdesenvolvidos, terceiro-mundo). Queremos neste ponto chamar atenção para o que foi e continua sendo imposto à, por exemplo, povos colonizados como cultura de melhor nível; no entanto, é mais interessante dar destaque ao que nestes processos se transfigurou em novas apropriações. Com a atuação direta das classes intelectuais de alto nível, o que é próprio de um sistema de vida, de formas culturais nativas, típicas e populares; é revelada, levado a uma análise, mas, depois retornam as suas origens na forma de produto cultural. Referimo-nos aos conhecimentos que têm como 
fundo a diversidade das formas de contato do homem com o meio para sua auto-reprodução. Toda via, não foi sem este intercâmbio que o sistema econômico se desenvolveu desde a Antiguidade. É preciso então melhor examinar o conceito de resistência quando identificamos a tais circunstâncias. É preciso, contudo, termos esclarecido que em um sistema de comunicação globalizado é sem sentido se propor ou sustentar qualquer concepção de pureza para cultura, mas que esta expansão comunicacional não sirva meramente de instrumento para subjugar os indivíduos ao consumismo mantido pela indústria cultural. Interessa neste ponto, observar a argumentação de Said (1995) sobre uma segunda definição de cultura, ou seja, como

[...] uma espécie de teatro em que várias causas políticas e ideológicas se empenham mutuamente. Longe de ser um plácido reino de refinamentos apolíneos, a cultura pode ate ser um campo de batalha onde as causas se expõem à luz do dia e lutam entre si $\left[\ldots . .{ }^{131}\right.$

Apesar de drástico, é natural que, em campo de batalha haja vencedores e haja vencidos. E, que contra os opositores haja os que resistam. Porém, nesta esfera, o tempo se encarrega de conformar tradições em novas tradições. Os jesuítas no Brasil, tanto impunham seus modos aos povos originários quanto assimilavam os modos deles; mesmo tendo como fim a civilização dos chamados selvagens. Assim sendo se consideramos a cultura como um espaço de ameaças e reações, também é possível constatarmos qualquer espécie de dominação cultural. Entendemos que é desta dominação (contra ela) que surge a resistência. Qual será então, o grau de sustentabilidade desta resistência? Até que ponto resiste? Carregando de ênfase a afirmação de Nazareth Ferreira (2006), quando diz ser "a alienação cultural - a mais perversa forma de alienação“ ${ }^{132}$ - questionamos também se não é esta resistência, inclusive, uma conformada persistência nesta condição.

Como indica Said (1995), seu enfoque é sobre as formas literárias, talvez por isso a alusão a Dante e a Shakespeare, autores distantes, quando se trata da formação cultural na America Latina, pelo menos no que se refere à cultura das

\footnotetext{
${ }^{131}$ Ibid., p.14

132 FERREIRA Op. cit., p.72
} 
classes subalternas. No entanto, complementando sua primeira definição de cultura, o autor chama a atenção para o poder de narrar, que pode ser interpretado como liberdade de se auto-descrever ou de formular sua história, e o poder narrar que pressupõe a relação social, ou seja, de narrar-se ao outro. Se, relacionamos este poder à liberdade, passamos a tocar na questão da resistência pelo que constatamos ser o seu oposto. Se a cultura conota também esta liberdade, o movimento de resistência deve ser no sentido de não perdê-la ou não permitir que seja vigiada, restringida. Assim sendo, seria coerente perguntar, se cultura e liberdade se opõem diretamente à necessidade de resistência? Ou, se há cultura e liberdade, há necessidade de resistir? Todavia, cada vez que se intensifica o foco sobre a questão da cultura, principalmente quando diz respeito às manifestações mais autênticas e arcaicas, costuma-se perguntar: por quanto tempo irá resistir, com estas respectivas propriedades? Com este questionamento iniciam-se os processos de investigações históricas até que aquela forma de manifestação da cultura esteja devidamente descrita, catalogada, transformada para o acesso midiático e logo disponível no mercado. É preciso que se enfatize que todo este processo por mais que utilize dos recursos tecnológicos da informação não garante a resistência. Garante o reconhecimento histórico, passando a ser concebida como demonstrativo de patrimônio cultural. Por isso é possível se ter uma noção do quanto desse patrimônio foi perdido, transformado, consumido ou persiste apesar das pressões das ideologias dominantes. Sendo assim, configurar a resistência significa dimensionar a força que lhe é opressora e o seu efeito sobre a cultura. Diante do mercado transnacionalizado, não há margem para se afirmar que exista plena autonomia econômica das nações; ao contrário, a interconexão entre as economias tem tamanha abrangência que ao se anunciar um desequilíbrio em alguma das balanças, imediatamente percebe-se a reação de toda esta esfera. Porém, não resta dúvida de que são as economias mais fracas que recebem o maior impacto. É o que constatamos com a atual crise econômica mundial. Talvez ao assistir ao noticiário as populações mais pobres perguntem por que uma imperícia no na maior economia do mundo compromete o preço do pão em nossa mesa? Esta questão tem resposta, mas a resposta não traz solução para o problema. Há no mundo, nos últimos anos, como reflexo de um processo de descolonização, um 
movimento intenso de migração. Refugiados da seca, da fome, das subcondições de vida etc. Entretanto as práticas de se agregar (anexar) e criar uma relação de dependência permanecem inculcadas principalmente quando se trata de explorar e tirar vantagens - lucro.

Pensando na configuração da resistência devemos entender que atreladas à dependência econômica estão outras diversas formas de submissão e controle:

Derivada da dependência econômica, a dependência cultural pode chegar a assumir proporções mais perigosas [...] visto que é o principal agente da circularidade em que se processam os mecanismos de dependência nos países colonizados pelo imperialismo, isto é, da imposição de hábitos alienígenas. ${ }^{133}$

Com base nesta afirmação é possível se colocar a seguinte questão, resistir deve corresponder a não-dependência ou apesar da dependência? É preciso então, entender o processo pelo qual se impõe a dependência cultural para se refletir sobre uma ou outra destas possibilidades. Há um nexo dialético nesta dependência ou na resistência; talvez sua principal contradição, esteja no que pode ser projetado à relação entre o centro e a periferia, esta ultima sendo de onde a produção e o excedente atende as demandas da metrópole. "A forma de desenvolvimento do capitalismo é a responsável pelo desenvolvimento de certos países e o subdesenvolvimento de outros." ${ }^{134}$ Assim, é possível se admitir que o primeiro movimento nesta relação seja de diferenciação e, por conseguinte de separação. Ao primeiro contato destacam-se aos olhos do colonizador advindo do centro, de modo geral, todo o exotismo das sociedades periféricas, este exotismo é por sua vez, interpretado sob explicações ideais e até cientificistas para se reafirmar e justificar o grau de inferioridade e deficiência daquelas sociedades. "Lamentavelmente, as classes dominantes e as camadas médias dos países dominados, bons aprendizes que são da ideologia colonialista, assumem esta posição junto às outras camadas sociais de seus países"135

\footnotetext{
${ }^{133}$ Id., "in" Por uma cultura Latinoamericana - AMARAL , R. et elii. Comunicação de Massa: O impasse Brasileiro. Rio de janeiro: Forense-Universitária, 1978. p. 129

${ }^{134}$ Ibid., p. 129

${ }^{135}$ Ibid., p.130
} 
Subsumida esta sub-condição uma vez que a classe dominante das sociedades periféricas ainda é quem dita os modos de como proceder diante dos países dominantes, estabelece-se então uma relação de interdependência que vincula, não sem desigualdade, uma nação a outra(s). Vale ressaltar que é exatamente através da manifestação da cultura que se pode medir o quanto e de que maneira uma classe determina os comportamentos em outra.

Os valores da ideologia burguesa são incutidos nos membros "superiores" das sociedades dominadas, criando os condicionamentos necessários para a pacificação interna, indispensável à reprodução das relações capitalistas de produção: "Eficácia, competição, sentido de tempo, achievement, performance, neutralidade afetiva, ascetismo racionalidade" entram no processo de socialização "das pessoas, nas famílias, escolas, fábrica, banco quartel ou outros lugares", preparando e induzindo 'as pessoas a harmonizar e automatizar as suas relações e atividades, como também a crer na possibilidade de sucesso pessoal ${ }^{136}$

Este paradoxo de sucesso pessoal, individual, como uma falsa noção de liberdade e de satisfação e demonstrada no que aparenta ser um livre exercício da cultura própria. Assim sendo, considerando a subsunção formal descrita acima, podemos dizer que, de um lado, ao exercermos a cultura própria, estamos dando demonstrações da diferença para nós, mas exotismos para eles, ou seja, demonstração das condições originárias que no período das colonizações foram julgadas inferiores mediante a cultura da burguesia européia; de outra forma e em contra-senso, ao desejar consumir a cultura superior imposta pelas mídias sob o comando das elites dominantes, estamos apenas cumprindo com os mandamentos da dependência. Contudo, prevalece um sistema de manutenção deste condicionamento quando os valores simbólicos são manipulados dentro da realidade do subdesenvolvimento. Constatamos duas forças pelas quais se consolida este processo funesto de manutenção. Uma dessas forças se verifica através da penetração das mídias quando

${ }^{136}$ Id., p. 130, passim 
[...] as culturas dominantes invadem os setores mais íntimos da vida privada das sociedades dependentes. Essa penetração através do consumo de produtos culturais (e outros) tende a desenvolver no meio onde atua a passividade e ate mesmo, a aceitação, de bom grado, dessa intervenção. A passividade imposta e o entretenimento divulgado pelos canais da indústria cultural levam o individuo a reduzir a sua participação efetiva na sociedade da qual faz parte, diminuindo ou anulando todas as possibilidades de conscientização do meio que o cerca, levandoo ao mais completo estado de alienação. ${ }^{137}$

A outra força esta embutida nesta mesma atitude de penetração, porém camuflada na aparência de proximidade quando valores culturais transnacionais incorporam ou associam a sua imagem a qualquer valor cultural local. Acontece tanto nas propagandas de produtos transnacionais quanto no uso corrente da língua:

O jornal, a revista, o livro, os folhetins, a música popular, o filme, o rádio, a televisão, o teatro, a escola, todos os instrumentos e as agências de transmissão de informações e conhecimentos são envolvidos no amplo processo de comercialização de mercadorias culturais. ${ }^{138}$

Acrescentam-se a esta lista todas as formas de mídia disponibilizadas no campo da informática. A respeito desta segunda força, entra no conflito uma crescente preocupação com a cultura nacional. No mais das vezes, simplificada na forma de cartão de apresentação às portas de grandes encontros de cúpula, a cultura nacional atomizada em uma ou outra forma de expressão típica deste ou daquele país do sul global, não é capaz de abranger na totalidade a cultura popular representativa da sociedade dentro de uma correspondência com o conceito de soberania. Portanto, não envolve todo o conteúdo sócio-econômico e político respeitante a formação daquela sociedade. "Pois cultura nacional é simplesmente uma cultura que se concretiza, que se expressa nas manifestações de um povo dependendo das possibilidades e limitações deste mesmo povo." ${ }^{139}$ Um demonstrativo histórico

\footnotetext{
${ }^{137}$ Ibid., p. 133

${ }^{138}$ lbid., p. 134

${ }^{139}$ lbid., p. 138
} 
desta preocupação encontra-se na hegemonia do capitalismo que "não deu chance à America Latina senão a de possuir uma cultura dependente, isto depois de destruir pela força uma das culturas mais avançadas existente na época em que iniciou sua expansão." 140

Este exemplo tem aqui significativa importância. Apesar do impacto, da voracidade e de toda destruição causados sobre as verdadeiras raízes das possíveis culturas latino-americanas, pelo encontro ou choque entre os povos, trata-se de um processo relativamente recente de modo que esta sombra de dominação que se abateu sobre nações da América Latina, mesmo da África e de outros povos que sofreram processos impositivos de colonização não é plena, nem total. "Se hoje se pode falar em uma cultura de resistência aos mecanismos de dominação imperialista, é por que esta se tornou tão clara e tão evidente que é impossível não sentir sua presença." 141

A esta altura podemos considerar que a contradição se explicita no jogo de forças entre uma cultura de resistência que "se desenvolve na luta contra a submissão, a despersonalização, o aniquilamento da cultura nacional" 142 e uma cultura da dependência que, a exemplo daquela segunda força, não cria senão um simulacro perigoso de mercado cultural global. O que se percebe daí é uma total imobilidade dos sujeitos das nações colonizadas. De um lado não podem preservar e vivenciar formas tradicionais da herança cultural pelo que, mediante as tecnologias avançadas julga-se um descompasso com os avanços do presente; e, por outro, as ações destes sujeitos em relação a estes avanços do presente são advertidas, pois está posto que haja um crivo hegemônico determinando o posicionamento de que cada nação no jogo da economia global:

E preciso, no entanto frisar que a procura de uma cultura nacional não implica limitação dessa cultura. Pelo contrário, busca, a partir de sua delimitação nos quadros da dependência cultural, assimilar aquilo que outras culturas possam oferecer em termos de enriquecimento, visando contribuir para a

\footnotetext{
${ }^{140}$ Id., p. 138

${ }^{141}$ Ibid., p.139

${ }^{142}$ Id., p. 139
} 
concretização da cultura universal, que é fruto e pertence a todos os homens. ${ }^{143}$

A este ponto, tendo apontado o problema entre resistência turvada e dependência dissimulada nos processos globais de homogeneização da cultura, outro grande equivoco se apresenta quando se tenta postular similaridade cultura nacional e cultura popular, em cuja concepção deturpada da sociedade de classe se reduz a uma armadilha ardilosa denominada folclore:

\begin{abstract}
Ainda, segundo os mais conhecidos antropólogos, pertencem ao 'folclore' as obras anônimas, transmitidas oralmente e de forma institucionalizada; é o tradicional, o de autoria coletiva, a expressão cultural do vulgo e da plebe, as chamadas 'artes menores'. Isto significa que a outra parte da cultura de uma dada sociedade é aquela que pode ser considerada como responsável pelas obras de autoria conhecida, transmitida não oralmente (!) e de forma institucionalizada, aquela que não é tradicional, cujos autores são individuais, sendo, finalmente, a expressão do que não é o vulgo, a plebe. ${ }^{144}$
\end{abstract}

A partir desta distinção e do fato de que a cultura nacional compreende um conteúdo político da formulação da sociedade, devemos afirmar prontamente que a visão deficitária de folclore, não é, nem em partes correspondente a um movimento de resistência, quando sim um ponto de vulnerabilidade. Antes, porém, devemos analisar que ainda permanece uma segregação classista que se baseia nesta distinção (inexistente) de uma cultura maior e outra menor, que só faz menoscabar a cultura pela "ideologia folclorista" como classifica Nazareth Ferreira (1978). Já tivemos oportunidade neste trabalho de colocar nossa visão a respeito deste escalonamento por classes na relação com a cultura. Cabe relembrar que a palavra de ordem, que ultimamente vem determinando este escalonamento é acesso. Um jornalista ou formador de opinião poderá se regozijar em saber que seu parecer sobre este ou aquele assunto atinge significativo público a partir de computado o número de

\footnotetext{
${ }^{143}$ Id., p. 139

${ }^{144}$ Ibid., p. 141
} 
acessadores de blogs. Contudo questionamos o alcance deste tipo de mídia quando se fala em demandas mais abrangentes. "Quando se fala em cultura nacional, geralmente faz-se referência a esta cultura dos grupos no poder, deixando-se de lado o fato de que esta cultura não é representativa do povo, sendo natural a uma ínfima parcela da população." 145 Desta forma, com acesso individualizado à cultura ou a opinião de quem quer que seja, assim como o folclore, está longe de representar a resistência da cultura popular nacional. Até poderá servi-la, mas não mais que a práxis. Outro ponto que importa destacar é o quanto esta conduta implica à relação com a cultura. De um lado projeta-se a luz sobre aquilo o que a classe dominante julga ser o mais alto nível de manifestação da cultura, que por isto mesmo, tem alto valor comercial. De outro, torna-se cada vez mais incomensurável a diversidade de produtos de uma cultura de baixo custo, de fácil acesso as massas, porém nunca sem a perspectiva de uma margem de lucro. Ambas as atitudes alimentam os processos alienantes:

\begin{abstract}
Aliás, o folclore, para ser menos consumido, ou para ser mercadoria para turista, deve ser caro. Sendo caro, será menos consumido, terá mercados menores (ou nenhum mercado). Em outras palavras, sua produção se tornará mais difícil, o produto mais raro e, portanto, mais caro. Onde o dinheiro é escasso, consome-se aquilo que é mais barato, produzido em série e que é facilmente encontrado em qualquer parte do país. Não é por acaso que se paga hoje uma fortuna por pratos típicos brasileiros (vatapá, feijoada, tutu à mineira) e uma ninharia por "americanos", hamburgers e outros alimentos "saudáveis."146
\end{abstract}

Assim, chegamos à consideração do que acreditamos ser o ponto mais crítico. Por representar talvez a mais inflexível oposição à cultura de resistência, a banalização da cultura (ou seria cultura da banalização, se assentir-se que ela é propositalmente produzida?). Impreterivelmente está implicada a correspondência inextrincável entre comunicação e cultura. Isto nos leva imediatamente a considerar a função de uma ciência em relação à outra; isto é, a comunicação social como sistema pelo qual se transmite e se mantém a

\footnotetext{
${ }^{145}$ Id., p. 141

${ }^{146}$ Id., p. 141
} 
cultura. Entretanto, a humanidade tem-se deslumbrado com a crescente conversão das linguagens em paralelo aos avanços tecnológicos dos meios de comunicação. Desta transição, se assim podemos considerar, algumas transformações e efeitos sobre a sociedades são destacáveis. Desde seu inicio, a marcha do progresso tecnológico, agora em um ritmo muito mais acentuado, alimentada com o carvão da acumulação capital, tem como conseqüência a racionalização do trabalho em função de maior eficiência e menor custo dos recursos da mecatrônica (mecânica, eletrônica e tecnologias da informação). Alem do desemprego em massa, há também uma desqualificação em massa, devido ao tempo de preparação de mão de obra especializada; relacionado a este dado há também um crescente desinteresse por atividades manufatureiras (pedreiros, costureiras, padeiros etc.). Outra decorrência desta marcha progressista é a insuficiente e, cada vez mais distanciada consideração à participação dos indivíduos nas cruciais tomadas de decisão, que resulta por sua vez de uma intensiva redução das possibilidades de mobilização social, apesar da amplitude de ofertas, do baixo custo e expansão do acesso, toda tecnologia aplicada ao fluxo informativo não conduz à reflexão política mais do que ao deslumbramento e a obcecação:

Ante todo, dice el experto inglês, debe conocerse la naturaleza ambivalente de las tecnologías de información, pues exige ser manejada acorde a uma política central no subordinada em forma exclusiva a la lógica del mercado, los privados o el lucro mercantilista. ${ }^{147}$

É preciso que levemos em conta que, inevitável, este avanço pode trazer elevação das riquezas materiais e culturais para as nações que estão mais bem aparelhadas e equiparadas com seu ritmo crescente, mas pode por outro lado representar "una amenaza para la estabilidad social y econômica, ya que su equilíbrio es sometido a uma inevitável alteración a partir de La introducción de las nuevas tecnologias."148 Partindo desta constatação podemos admitir ao menos, três principais etapas para que uma nação em desenvolvimento terá de superar para esta equiparação. Em primeiro lugar adquirir os recursos

${ }^{147}$ GONZÁLEZ-MANET, Enrique. Nuevas Formas de Comunicación y Cutura: como enfrentar las Nuevas Tecnologias? Revista Comunicação \& política: comunicação na América Latina CBELA - Centro Brasilerio de Estudos Latino Americanos Ano XIII №22-23-24-25. São Paulo, 1993. p. 21

${ }^{148}$ Ibid., pp. 21-22 
materiais da tecnologia mais recente que a princípio se restringe ao centro onde se desenvolveu; o custo dessa tecnologia é alto e sua produção é limitada; a segunda será pagar pelo acesso à tecnologia, ou seja, ao conhecimento para que ela funcione adequadamente conforme a demanda local; e, uma terceira e fundamental mudança será preparar e qualificar pessoal para interagir na nova linguagem anexa a tecnologia. Até que uma Nação emergente consiga executar tamanho salto qualitativo para se aproximar do fluxo do mercado global da informação, muitas outras metamorfoses tecnológicas se deram, aumentando a distância que separam ricos e pobres e a dependência ou (re)-colonização conforme o compromisso firmado na tranzação. Na lógica matemática, quanto maior a velocidade, mais rapidamente se dá e maior é o distanciamento.

Voltando as decorrências do processo de desenvolvimento da tecnologia da informação, a partir da segunda etapa citada, quanto à participação dos indivíduos na ordenação da sociedade, podemos então, constatar o terceiro e mais grave dano causado pela exploração (neo)-liberal da comunicação, que a partir deste ponto trataremos como também já identificamos acima, a cultura da banalização.

Em momento anterior tivemos oportunidade de observar que o virtualismo das linguagens digitalizadas planifica as relações humanas. Porém, é sempre construtivo acrescentar outras visões:

No entanto não se podem descartar inteiramente as hipóteses no sentido de que os meios de comunicação cumprem funções de "escola paralela" (como as elaboradas no conhecido Informe Mc. Bride, preparado pela UNESCO), na medida em que exerçam impacto ideológico sobre as consciências. Embora seus conteúdos não sejam estritamente educativos nem produzam conhecimento sistemático, geram efeitos de socialização capazes de competir com a hegemonia funcional da instituição escolar. Alem disso, as teletecnologias capitaneadas pela mídia tomaram a dianteira no tocante à expressão imagística. ${ }^{149}$

${ }^{149}$ SODRÉ, Op.cit., p. 99 
Pela complexidade das análises que são empreendidas nos campo das Ciências Humanas e da Comunicação Social é ainda muito difícil medir os efeitos das novas tecnologias da informação sobre a qualidade de vida e a dinâmica social. Há indubitavelmente uma sensível fixação sobre as perspectivas comunicacionais a partir dos efeitos que podem ser obtidos pela praticidade e replicabilidade da imagem, como também já foi dito. "Puede decirse que la televisión y el video ejercen mayor influencia que religión la escuela em la mayor parte de los países, en particular em Estados Unidos, donde la pantalla domestica se enciende durante siete horas diárias." 150 Atualizando a reflexão devemos acrescentar que, em muitos países mesmo em fase de subdesenvolvimento, as televisões estão programadas para emissões por vinte e quatro horas diárias e as religiões, por exemplo, já se prontificaram a uma porção significativa deste tempo.

Contudo, quando se pretende uma abordagem sobre a cultura da banalização, devemos direcionar o foco das argumentações sobre os assuntos; perguntamos qual a relação do conteúdo veiculado com os efeitos comportamentais da tecnologia da comunicação? "Todo ello incluye nuevos $-y$ posiblemente nocivos - linguajes y estilos, actitudes y comportamientos de efecto paradigmático, cuya difusión global unidirecional es muy difícil de contrarrestar." 151 Assim como as nações são impulsionadas a equiparação tecnológica, os indivíduos das sociedades, principalmente os jovens, mais afeitos a esta atitude, e por isto mesmo alvo fixo da produção tecnológica digital, também são assim impulsionados pelo bombardeio das novidades deste setor. O fluxo e a velocidade do consumo dessas novidades praticamente restringem a capacidade de qualquer controle sobre o conteúdo informacional que através dela se tem acesso, em outras palavras o tempo e excepcionalmente curto para uma avaliação sobre os efeitos que deste conteúdo possa se verificar. Ousamos, porém afirmar que, de um lado interessa as empresas transnacionais deste setor, em detrimento de um conteúdo mais útil, para obtenção de maior lucratividade; e, de outro lado, interessa aos indivíduos como uma forma de equiparação entre classes; mais

\footnotetext{
${ }^{150}$ Ibid., p. 23

${ }^{151}$ Ibid., p. 23
} 
do que a formação como pré-requisito para se articular no meio social, ou seja, mais do que apreender a cultura, em seu sentido mais elevado, interessa é portá-la; tanto no que diz respeito nos recursos de acesso a ela, quanto nos dispositivos para sua armazenagem. Podemos admitir que de alguma forma já não estejamos mais tão restritos à passividade mediante as pantallas domésticas, Ao apelo consumista desta tecnologia corresponde determinada interatividade que se admite aplacar por hora os anseios por participação ou solapar definitivamente o pensamento criativo. A respeito desta pseudointeratividade, há certamente quem se satisfaça em concebê-la com uma nova cultura, tecnocultura para Muniz Sodré (1996), difícil de apreender, de se introjetar e ineficaz para a predição da atividade humana. Porém, mais complexo se torna a compreensão de que, sendo esta cultura banalizada, o fluído vital da comunicação em massa, exista propositadamente fomento para tal devastação do campo de articulação das faculdades humanas em função de ideologias (neo)-liberais.

Se tentássemos revelar uma ordem nesta conduta, perceberíamos que primeiro lança se um apelo ao desejo ou ao interesse, a vida de uma estrela da mídia, um novo game, uma nova tribo de comportamento paradigmático ou propriamente uma nova tecnologia em veículos, celulares etc. Enquanto isso o jornalismo faz através de uma varredura sistematizada, os resumos dos fatos cotidianos mundiais convertendo-os as linguagens das novas tecnologias. A partir daí, o consumo, a dependência e mais consumo. O fluxo dessas mensagens não conduz efetivamente a um aprofundamento nas reflexões. Mesmo aos acessadores dos blogs mais bacanas, Pois, mais do que antes, hoje conduzem à morbidez, à falta de criatividade e a inaptidão das faculdades do ser humano quando este automatiza e rotinifica seu movimentos e gestos deixando de articular criativamente seus membros e mente. Submetido a um sistema de miniaturização dos equipamentos, pequenos compartimentos contendo grande volume de informação, representa-se a cada minuto com grandes transformações quantitativas aos círculos das grandes corporações transnacionais. Ao mesmo tempo em que representa revoluções qualitativas ao contrário e por indivíduo, ao se reduzirem o campo de visão a minúsculas teclas e ícones com diversificadas ações digitais programáveis. 
Para que possamos examinar as contradições entre a cultura de resistência e a cultura da banalização, precisamos retroceder a concepção de "cultura universal em concretização" ${ }^{152}$ da qual fala Nazareth Ferreira (1978). Tomando-se como um processo a universalização da cultura, devemos ter sempre em consideração, as possíveis manobras correlatas a este dimensionamento.

Para os que defendem a idéia de uma nova cultura, a automatização do homem pode representar propriedade e reciprocidade uma vez que toda tecnologia é desenvolvida em função do adiantamento do humano, mas esta concepção é sem dúvida de um caráter futurista. Todavia, não se pode desconsiderar que mesmo neste contexto o homem ainda trabalha, operando hardwares com os mínimos gestos e quem sabe um dia se alimentando exclusivamente de pílulas sintéticas. Não estamos através deste trabalho, tentando aludir à esfera tão incerta, o que se pretende indagar aqui é a respeito de qual cultura é mais própria e menos banal. Se a cultura que provém dos sensos de propriedade e reciprocidade que pode haver entre o homem e 0 meio, se a que advém da concepção de que "o trabalho é a inevitável mediação do homem com o meio" ${ }^{153}$, se a que tem em sua base a comunicação como faculdade humana intrínseca e um dos principais mecanismo de manutenção e preservação dos modos culturais. E, se o que constatamos é um encampamento total dos meios de comunicação, a mais recente e promissora fonte de lucro dos interesses capitalistas sob o controle de poucas e mega-corporações transnacionais, sob quais modos culturais deve se configurar a resistência e quais contingentes arregimentar para tal atitude? O trabalho como imanência compreende o ciclo da força que prevê o desgaste e a recondução da força, basta que observemos um formigueiro que ininterruptamente recompõe a força de trabalho. Contudo o que consolida a perpetuação deste ciclo é o alimento. A cultura, imanência própria das subjetividades do mundo do trabalho não é senão uma concepção das essencialidades do fruto do trabalho. Do trabalho, o seu fim e não sua racionalidade:

\footnotetext{
${ }^{152}$ FERREIRA, Op.cit., p. 139

${ }^{153}$ Ibid., Op. cit. p. 99
} 
La información proviene hoy de una gran duversidad de médios interativos e interconectados, pero su transmisión sigue siendo em gran parte unidireccional, y la aparente multiplicidade de técnicas y formas de comunicación reproducen como em um juego de espejos sus mismos origens y estructuras de poder.

Este fenômeno se aprecia em las realciones de mercado, comercio y la economia. Pero también em las corrientes culturales de uma difusión masiva que contribuye a la despersonalización, la universalización de la vulgaridad y el superficionalismo como concepto de vida. Uma respuesta podría ser, a escala local, el enraizameiento de la identidad y los valores próprios. ${ }^{154}$

Por este pensamento se evidencia que em contraposição a vulgaridade e a superficialidade como concepção de vida, procura-se na cultura, o sentido; os modos culturais ou em partes, algumas manifestações culturais podem mostrar-se inexplicáveis, muitas vezes devido sua relação com concepções metafísicas. Mas, pode-se afirmar que sem um sentido dificilmente se justifica a proposição de uma configuração para a cultura de resistência. Ou, esta configuração somente se formula sobre a base de uma cultura de valores próprios. Por isso também enfatizamos que a observação desses valores só é possível mediante a manifestação da cultura propriamente dita, que no mais das vezes respeita a dinâmica histórica e do cotidiano, abrangendo-os na sua totalidade ou em periodizações cíclicas como, por exemplo, os momentos de festas.

Respeitando-se a metodologia dialética é preciso ter-se em consideração a superação dos conceitos como neste caso o de resistência:

Hablar hoy de izquierdas, injusticia social, necessidades públicas, dominación y dependência, ya no significa, como antes, intensificar-se com el humanismo y la esperanza de justicia, sino asociar-se a uma causa aparentemente perdida. Son términos devaluados por la coyundtura política actual em em contexto unipolar. Incluso se quiere hacer creer que las causas que generaron las luchas progresistas ya no existen y que presenciamos el fin de las ideologias contrárias a la filosofia clássica Del libre mercado y el libre flujo de ideas y valores, consagrados por el pensamiento utilitarista cocidental. ${ }^{155}$

\footnotetext{
${ }^{154}$ Ibid., p. 26

${ }^{155}$ Id., p.26
} 
Entretanto não necessitamos de aprofundamentos científicos para constatar a complexidade das conjunturas sócio-econômicas e culturais atualmente no mundo.

Em realidad los problemas han emperoado. Hoy hay más hambre, deudas, desigualdad y violência em el mundo, um mundo más controlado por la fria eficácia de la técnica, en el que todo está supervisado y donde comienza a producirse una inquietante elitización de la cultura debido a la progresiva mercantilización del conocimiento y la comercialización global de las bases y bancos de datos. ${ }^{156}$

Persiste, portanto a indagação sobre quem teria, deliberadamente, controle sobre os meios de comunicação. As sociedades sempre caçaram seus monstros e monstruosidades. Nos últimos anos dois casos alardearam 0 mundo, no Brasil o brutal assassinato de uma menina pelos próprios pais, ao qual a imprensa novelística intitulou O Caso Isabela e no mesmo ano a prisão do monstro austríaco; não são mitos. Com estas citações queremos afirmar que não se encontrará na história um autor desta ordem (neo)-liberal a quem se possa impingir a responsabilidade. Há certamente os que se beneficiam com o capitalismo, quem o alimente, o promova e o explore sem escrúpulos. Mas, nesta corrente, estes mesmos apenas seguem ao impulso liberal. De outro lado e em contraposição a este impulso, persiste a indagação sobre quais são os dispositivos e seus respectivos procedimentos para que se garanta a força e a eficácia daquilo que se puder revelar nas condutas humanas como valores próprios da cultura.

Sabemos que há culturas populares porque há desigualdade (ponto de partida) social com relação à distribuição de recursos. Dentro desta desigualdade estão de um lado os que têm acesso a bens de consumo e dentre eles, os bens de consumo culturais, e de outro, os que não têm. Porém como pensar quando e dentre os que realizam e mesmo os que idealizam estes bens culturais estão sujeitos em condição de subalternidade e, para sermos mais atuais, descontextualizados e ou excluídos. Escolas formam agrônomos, mas não recriam a relação afetiva do homem com a terra. Portanto, que não se resumirá tão somente a solução em uma das partes. Isto é, tanto as demandas da

\footnotetext{
${ }^{156}$ Ibid., p. 27
} 
produção cultural (não de entretenimento), quanto sociais são dependentes, a nosso ver das mesmas transformações. Estas, não estão definitivamente contidas senão na consciência das relações materiais.

Podemos então, quanto ao tema desta sessão argumentar sobre a resistência física, correspondente a capacidade de superação nos esforços. Neste ponto poderemos contrapor expressão cultural artística complementar ao trabalho e o próprio trabalho, isto é o trabalho como garantidor da subsistência, da vida. Ou seja, participam trabalho e cultura dos mesmos esforços. De outro lado laser depois de uma semana ou um dia de trabalho, normalmente solicita uma dose extra de energia. Tivemos oportunidade de ouvir de um dançador de Moçambique de aproximadamente 72 anos, durante uma Festa do Divino, que nesta ocasião, antes de sair para a função, já havia feito a lida da roça, cuidado da criação, ordenhado o rebanho. A entrevista se deu por volta das $17 \mathrm{~h} 00 \mathrm{~h}$, e o grupo já dançava desde as 10:00h. ${ }^{157}$

Podemos argumentar também sobre a resistência histórica, reconhecendo a capacidade de se manter como atividade expressiva, inerente as atividades humanas. Como ação política contra a subsunção formal (folclore). A resistência no tempo, por não sucumbir facilmente à ilusão do avanço. E ainda o que corresponde à possibilidade de resistência ideológica - a ação filosófica de não se subjugar a ordem capitalista, quando, muito mais do que permanecer resistindo, é consenar o caráter de impagável.

\footnotetext{
${ }^{157}$ Entrevista concedida a este pesquisador Durante a Festa do Divino na cidade de São Luiz do Paraitinga no dia 04/06/2006
} 


\section{2 - O Ambiente e a Cotidianidade.}

Tratamos deste ambiente, observando os aspectos, físico e estrutural correspondentes às circunstâncias históricas e, de outro lado ao que poderá corresponder às configurações subjetivas, isto é, à forma como os indivíduos se organizaram no ambiente. Subjetivamente, a relação com o ambiente só poderá ser consolidada na forma de apropriação, considerando-se o momento, o lugar e os elementos que ali se encontram. A partir desta conjugação é que têm origem ou manifestam-se os fenômenos. Evolui então a cotidianidade. Assim, a festa é um ambiente da cotidianidade.

Devido a um movimento de patrimonialização, muito provavelmente resultado de uma onda de nacionalismo no Brasil principalmente, a partir da década de 20, questionado pelo antropofagismo na arte moderna, a cultura popular passou a ser objeto de levantamentos para obtenção de uma panorâmica ou de uma feição identitária de um patrimônio calculado como riqueza nacional, ou uma espécie de catálogo da diversidade. Esta índole ou personalidade, ou ainda, sua formação, nunca é desprovida dos reflexos da relação com os outros (uma espécie de, se vocês são assim, nós somos deste jeito) Assim, não é difícil encontrar, de forma sintetizada, estas referencias a respeito das raízes históricas. Neste afã de compilar dados sobre as multíplices possibilidades de manifestações culturais de raízes mais arcaicas e, devido a sua preservação no tempo, em função de fatores da própria cotidianidade, não se permitiu em muitos casos um visão mais ampla dos estudiosos. A metodologia aplicada neste processo reverteu a um estado de parcimônia as manifestações. Em tal momento o sentido de pertencer passou a corresponder mais necessariamente aos interesses de consolidação da soberania da nação. Tratava se então de uma grandeza nacional do povo. Não exatamente do povo, em si, como grandeza. Contudo, mais recentemente, é possível constatar uma preocupação maior com elementos desta força que representam não mais do que somente a possibilidade de se identificar, mas identificar nas suas subjetividades, sua capacidade de interpretar o mundo em processos e meios, com os recursos do entorno, com a criatividade. Do reconhecimento desta força, principalmente com relação ás manifestações expressivas que do ponto de vista da produção da riqueza desde sua origem tiveram pertinência exorável, desenvolveu-se, por exemplo, o conceito de resistência atribuído a 
núcleos conciliares como a família e suas adjacências. Esta resistência se refere à persistência no tempo, de uma mesma forma, uma solidificação frente às influências do poder real exercido, neste caso por Portugal. Para uma contextualização histórica e, no que se refere a um ambiente onde analisamos as origens daquelas formas de expressão cultural, a saber a Dança do Moçambique e o Jongo, no âmbito de formação do povo paulista, consideramos o fato de que para que

[...] houvesse a manutenção desses comportamentos três fatores foram muito importantes: o isolamento da capitania, a pobreza e a capacidade de resistência [grifo nosso] de seus moradores. Para a existência desses três fatores, aparecem como principais causas estruturais a centralização das decisões governamentais e o patrimonialismo. ${ }^{158}$

Consideramos também que se há uma forma de dominação por parte de uma hegemonia governamental, há, por conseguinte formas de resistências, como conotações da ideologia implícita nas subjetividades que se transformam em explicitações, - e por se referirem as relações materiais - da cultura. Isto quer dizer que, conforme a dinâmica social ou de acordo com as relações de poder sobre a população não é difícil detectar em um estudo aprofundado ou sintático as alternativas de interpretação deste poder. Queremos entender que muitas vezes nesta interpretação caricatural do poder as classes subalternas inventam tradições e ao repeti-las constroem as tradições culturais:

Apesar da infinidade de mecanismos de hierarquia e subordinação, os pobres estão constantemente expressando uma enorme força de vida e produção. Para compreendê-lo, é necessária uma inversão da perspectiva. È verdade que precisamos reconhecer e protestar contras as maneiras como um número cada vez maior de pessoas em todo o mundo se vêem privadas, de renda, alimentação, abrigo, educação e cuidados de saúde adequados - em suma, reconhecer que os pobres são vítimas da ordem global do Império. Mais importante ainda, precisamos reconhecer que os pobres não são apenas vítimas, mas também agentes poderosos. ${ }^{159}$

\footnotetext{
${ }^{158}$ CAMPOS, Judas Tadeu de Currículo e Cultura: A formação do Caipira. Dissertação Doutorado em Educação - Currículo. -São Paulo: PUC/SP, 2002.p. 25

${ }^{159}$ HARDT; NEGRI, Op. cit., p. 175
} 
A partir destas proposições, concluímos que a pobreza é um dos elementos a constituir as condições ou circunstância em que de uma forma ou de outra alguma produção se faz. Antes, porém, é necessário que se ressalte que em ambos os casos há uma decorrência de um regime de poder, contudo no primeiro caso a pobreza se institui pela distância em relação a um centro de maior circulação de mercadorias. No segundo, deve se ter em conta a produção da pobreza conferida à mercantilização global. Quando tudo se transforma em mercadoria cria se um sistema geral de demérito (o mesmo que a perda do senso de propriedade) por qualquer coisa daquele que está desprovido; também se confere a educação, que funcionando para dotar de saberes o indivíduo, torna-se incapaz de estabelecer de vez os elos de propriedade e de reciprocidade entre o homem e o meio. Tendo este de se sujeitar às regras do mercado. Deve-se esta produção da pobreza também aos saltos tecnológicos que cada vez mais definem as posições na sociedade de classes criando uma grande margem de pessoas excluídas das possibilidades de acesso.

Considerando então o ambiente de formação cultural, devemos observar as condutas políticas que representaram historicamente a organização da sociedade e da mesma forma influenciaram todas as subseqüentes mudanças. Um ponto de referência para que se observe este processo podemos obter remontando a

[...] época do domínio espanhol (1580 - 1640), as Ordenações Filipinas, conjunto de normas que regiam todo Império, promulgadas pelo Rei Felipe I, em 1603, marcaram toda história colonial brasileira e parte do Brasil Independente. As Ordenações eram o estatuto da organização política, administrativa e jurídica do reino, com uma minuciosa especificação das atribuições dos delegados do rei: "O rei é a lei animada sobre a terra e pode fazer lei e revogá-la quando vir que convém fazer assim [...]. ${ }^{160}$

Segundo levantamento feito por Campos (2002), "as Ordenações vigoraram em nosso país, totalmente até 1830 e, em parte até 1922."161 Podemos constatar, mediante este fato histórico, a influência de uma hegemonia política, total ou

\footnotetext{
${ }^{160}$ ORDENAÇÕES Flipinas, Livro III, título 75, § $1^{\circ}$ apud CAMPOS, 2002 pp. 26-27

${ }^{161}$ CAMPOS, Op. cit., p. 27
} 
parcialmente, determinando os caminhos de formação do que viria a ser uma nação pelo espaço de tempo de pelo menos 319 anos. Por mais que tenhamos que admitir que na fase inicial deste processo, nos primeiros contatos com portugueses, espanhóis e outros que por aqui passaram na disputa por territórios predispostos a colonização, não houvesse sociedade propriamente dita, é mais difícil compreender e aceitar que até nos momentos finais do século XVI ainda persistissem mesmo desvanecidas tais posturas. Contudo para que tenhamos, mais claramente, uma noção do ambiente político onde estão calcadas muitas dessas condutas, das quais se tem exemplo até os dias de hoje, vale acrescentar que:

Sob essa estrutura governamental se formava a gente paulista e São Paulo ia sendo povoado. Ensaiava-se nos primeiros passos do enxerto da monarquia européia, o domínio autoritário sobre a população, abrandado com a domesticação dos índios (sic) e dos portugueses fugitivos da cólera do rei. Era um processo duplo: a subordinação impiedosa e a amalgamação persuasiva da sombra da violência. ${ }^{162}$

Ate este ponto temos de algum modo uma definição do cenário (Capitania de São Paulo), os sujeitos (portugueses e povos originários) e ainda que transitoriamente, a imposição das formas de ordenação das relações sociais de acordo com a passagem acima, assimilada da monarquia européia. Campos (2002) destaca, a respeito das condições dos cidadãos nos municípios a seguinte distinção:

Eleitores e eleitos pertenciam à categoria dos homens-bons. De acordo com as Ordenações Filipinas, os homens-bons eram constituídos pelas pessoas que possuíam propriedades e residiam no município. Não podiam pertencer a esta categoria os operários, peões e portadores de sangue impuro, embora muitas vezes esta ultima proibição, feita para afastar os judeus, fosse ignorada. Ser um homem-bom significava não somente ser considerado uma pessoa importante no local, mas também demonstrar que estava ligado ao poder central isto é à metrópole. ${ }^{163}$

\footnotetext{
162 FAORO, 2000, apud CAMPOS, 2002, pp. 27-28

${ }^{163}$ CAMPOS, Op. cit., pp. 29-30
} 
É preciso não deixar de considerar que queremos tratar das raízes históricas para exatamente colocar em questão, por quanto tempo se mantém as problemáticas das relações humanas até que se equalizem as transformações quantitativo-qualitativas reais? Defendemos que é através de maior conhecimento e consideração a fatores sociais históricos, dos quais talvez pouco ou nada se tenha aprofundado. Quando confrontamos os setores nos quais se subdivide o sistema social, percebemos a exemplo da política e da educação o quanto estas esferas ainda conservam indicativos daquele tipo de ordenação.

Um procedimento que nos conduz a visualização do sujeito neste processo é através da observação da sua compleição étnica, admitindo o encontro de culturas; e também espiritual, considerando a construção, vamos assim colocar, de uma terceira porção étnica. Pela forma como os indivíduos gerados deste encontro de culturas se articularam no cotidiano e nos conflitos, podemos destacar que

[...] o estabelecimento do poder real na Capitania de São Vicente e a expansão territorial da geografia paulista, significaram também a formação de um tipo de cultura. Para o surgimento desse modo de vida foi muito importante a formação de uma etnia, que acabou se tornando predominante.

O paulista em grande parte era o resultado do cruzamento dos portugueses com as mulheres da terra [...]. E foi a esses homens que se deu o nome de mamelucos. ${ }^{164}$

Assim identificada, momentaneamente esta predominância étnica na região cabe também acrescentar que

[...] nas regiões onde a produção econômica era mais intensa e exigia a presença de escravos de origem africana, predominou a miscigenação de brancos com os negros. Assim, o tipo de mistura de raças era também um fator que denotava $o$ desenvolvimento ou o atraso da região.

Se de um lado observamos os imperativos sócio-econômicos do Estado sobre a população, de outro será importante termos em mente a capacidade de subjetivação do sujeito, ou seja, sua capacidade criativa não institucionalizada

${ }^{164}$ Ibid., pp.30-31 
ou como forma de fugir da institucionalização. Em outras palavras, tudo que se referir às faculdades de conceber, à propriedade para interpretar e à capacidade de transformar; e que, portanto, não Ihes seja imposto. Uma destas estratégias identifica-se no clã familiar:

A família extensa, que supera os limites dos bairros, ainda hoje é observada em muitas famílias de origem caipira, onde logo após o casamento, o casal passa a tratar os parentes do cônjuge como os avós, tios, primos e até os compadres como se fossem da família consangüínea de origem. Isso se expressa não só nos vocativos, mas no acolhimento das casas. ${ }^{165}$

Antes de tudo, é necessário que se faça a seguinte distinção entre um clã familiar capaz de atualizar sua demografia constantemente e a qualquer instante; e uma familiar nuclear estatística. Também que, estamos traçando um perfil histórico das condições para a explicitação de determinadas subjetividades. No estudo de Campos (2002), reconhecemos as circunstâncias de imposições e outras estratégias a que se permitiam nesta época, devido às vastidões ermas.

[...] esse isolamento, era muito mais do que causa ou conseqüência da pobreza da pobreza em que os moradores de São Paulo viviam. Nessa época, duas providências a que as autoridades sempre recorriam ameaçavam os moradores: o recrutamento para o serviço militar e as cobranças de impostos e do dízimo. Em outras palavras, o isolamento dos paulistas parece denotar uma forma de resistência [grifo nosso] que eles desenvolveram contra essas ameaças. ${ }^{166}$

Havemos de considerar que estamos em busca de configurar as forma e conteúdo do sujeito que é agente da cultura, portanto merece nossa atenção o que possa indicar sinais de singularidade. Podemos afirmar que a consolidação destes sinais em habituais comportamentos ou práxis, compreende os modos culturais através dos quais muitas vezes toda uma civilização escolhe viver. Temos que admitir, contudo, que esta não é a maior prerrogativa do desenvolvimento, mas não se pode desconsiderar que trata-se de modos mais autênticos da concepção do mundo. Considerando-se a práxis decorrente de

\footnotetext{
${ }^{165}$ Ibid., p. 36
}

${ }^{166}$ Ibid., p. 38 
um processo de subjetivação, isto é, que diz respeito ao sujeito, vale destacar, por exemplo, "esse isolamento os moradores de São Paulo a usar, até o século XVIII, um dialeto chamado língua geral [grifo do autor], uma mistura da Língua Portuguesa com o Tupi."167 Não cabe aqui a pretensão de isolar e caracterizar um tipo de indivíduo quando se faz tal referência aos primeiros habitantes da colônia, mas sim o objetivo de ampliar o foco sobre as subjetividades que serviram de base conceitual para posturas de resistência e de articulação frente a um mundo que se desenha nos moldes da colonização européia, vale destacar do estudo de Campos (2002) que afirma:

É nesse século que parecem haver-se configurado os traços fundamentais da cultura caipira que (sic) vinha esboçando desde o inicio da colonização. Isto significa que os termos paulista e caipira eram, na prática, equivalentes. E que em meados dos setecentos a cultura caipira já estava definida e consolidada. ${ }^{168}$

Assim, podemos admitir, até este ponto que, trata-se de um conjunto de fatores que na dinâmica dos deslocamentos, desde a saída das Caravelas do porto português, se podemos daí situar um marco, o encontro de culturas díspares e o isolamento das famílias em bairros rurais, vieram a configurar um modo de vida bastante próprio. É relevante assinalar que, todo este cotidiano estava mais relacionado ao meio rural, ou seja, onde, naquela época, certamente toda tecnologia nascia especificamente para instrumentalizar o homem mediante as demandas diárias - nas relações materiais. Da mesma forma podemos calcular que também as relações humanas se orientassem de acordo com estes meios e estas atividades; hora de dormir, hora de trabalhar e momentos para confraternizar; "[...] essas famílias estavam presas a uma organização de vizinhança, o bairro rural, de contornos suficientemente consistentes para dar aos habitantes a noção de pertencer, [...]" ${ }^{\text {"169 }}$ talvez, o mesmo que ser próprio de um processo dinâmico que produz sociedade, na melhor acepção da palavra, contrapondo diametralmente ao que hoje chamamos de sociedade do consumo:

\footnotetext{
${ }^{167}$ HOLANDA, 2000, apud CAMPOS 2002, p. 35

${ }^{168}$ CAMPOS, Op. cit., p. 45

${ }^{169}$ QUEIROZ, 1973, apud CAMPOS, 2002, p. 45
} 
Quando passarmos por momentos difíceis e por necessidades sérias, as pessoas não pedirão fiança antes de decidirem se nos ajudarão; não perguntarão como e quando retribuiremos, mas sim do que precisamos. E raramente dirão que não é seu dever ajudar-nos nem recusarão seu apoio só porque não há um contrato entre nós que as obrigue a fazê-lo, ou porque tenhamos deixado de ler as entrelinhas. Nosso dever, pura e simplesmente, é ajudar uns aos outros e, assim, temos pura e simplesmente o direito de esperar obter a ajuda que precisamos.

E assim é fácil ver por que a palavra "comunidade" sugere coisa boa. ${ }^{170}$

Quando relacionamos as demandas de produção cultural e sociais dependentes das mesmas soluções, queremos enfatizar que reconstruir o ambiente da comunidade está entre as ações mais necessárias. Julgamos que além do pertencer é na comunidade, de maneira natural, que se confere a cotidianidade a medida das relações.

${ }^{170}$ BAUMAN, Op. cit., p. 8 


\section{3 - Raízes Históricas do Moçambique e do Jongo}

Como apresentado no inicio da sessão anterior, uma onda de patrimonialização organizou e em muitos casos padronizou a forma de se olhar para as raízes históricas das manifestações expressivas da cultura. Muito provavelmente por que o ambiente que lhes era próprio ao longo do tempo se desfez. Devemos ter em consideração, por hora, como um momento bastante relevante do contexto dos bairros rurais que, "a festa do padroeiro, realizada nas capelas rurais, era a forma e o momento em que os moradores afirmavam a personalidade do bairro, em relação aos bairros vizinhos." ${ }^{171}$ Devemos ressaltar que não está em debate a questão da afirmação da personalidade nem a possível distinção entre um bairro e outro. Também não está entre os objetivos defender o bairro como medida ideal de urbanização, importa-nos muito mais a festa como ocasião para a comunicação dos valores, das idéias e dos modos comportamentais assimiláveis em uma mobilização coletiva. Em outras palavras, a ideologia subalterna como energia desta mobilização ou da ordenação da sociedade; no pensamento de Todorov (1993), as "justificações que lhes foram dadas;" entendemos que quanto mais marcante for uma destas ocasiões mais forte a filosofia historicista da sociedade que passa a contar para sempre com aquele momento como sendo um dispositivo ideológico.

A partir deste elemento, esta energia, a festa, como um dos movimentos da interação comunicacional nestes espaços - os bairros -, passamos a abordar mais uma forma de deslocamento que pelo que podemos interpretar indicam mais precisamente as raízes históricas do Moçambique e do Jongo:

Um fato muito importante para as mudanças que ocorreram no Vale do Paraíba foi a instalação da Corte na cidade do Rio de Janeiro, em 1808, estimulando progressivamente a demanda de gêneros alimentícios e de gado para o abastecimento da excapital do Vice-Reino. Isto estimulou a passagem da cultura de cereais, destinado ao gasto da família e a sobra de uma pequena produção de mercado, para a promoção de uma produção agrícola excedente, com fins comerciais ${ }^{172}$

\footnotetext{
${ }^{171}$ QUEIROZ, 1973 apud CAMPOS, 2002, p. 46

${ }^{172}$ AGUIAR, 1949, apud CAMPOS, 2002, p. 50
} 
Concernente a estas mudanças, no plano econômico devemos lembrar a diferença entre as diversas regiões no Brasil colonial e principalmente no que se refere à conformação étnica da população do Vale do Paraíba, pois:

Só a partir do segundo quartel do século XIX é que um outro elemento racial, o negro, passou a ter importância, do ponto de vista demográfico, étnico e cultural na região, em face do crescimento do número de fazendas dedicadas ao café. ${ }^{173}$

Assim, podemos admitir que inexoravelmente o desenvolvimento sócioeconômico atrelado à crescente expansão capitalista, com as possibilidades de grandes margens de lucro mediante 0 acúmulo latifundiário, também representou dialeticamente uma força essencial no desenvolvimento sóciocultural. A complementação da conformação étnica, o aumento da população e a divisão social do trabalho corresponderam diretamente a novas formas de comportamento, ou seja, a novas subjetividades para a interpretação do contexto histórico:

A demografia do Vale do Paraíba foi uma mostra da crescente importância do café: em 1836 a população valeparaibana era constituída por 105.679 habitantes, sendo a região mais populosa da Província de São Paulo. Em 1854, ela crescera para 146.055 moradores. E em 1886, quando as plantações de café atingiram o apogeu, a população atingiu a sifra de 338.537 habitantes. ${ }^{174}$

Tal densidade demográfica pressupõe certamente maiores implicações na definição dos espaços em especial para as manifestações expressivas da cultura. De um lado por que se torna mais evidente a demarcação das propriedades privadas e de outro a predominância hegemônica de uma nova ideologia nos espaços públicos. Com isso teria certamente se redesenhado a forma de ocupação dos espaços bem como as condutas. Um dos pontos marcantes deste período, a exemplo das mudanças que ocorreram, é o que segundo Campos (2002) foi sancionada como Lei oㅡ 601, em 18 de setembro de 1850 e que recebeu o nome de Lei da Terra; e acrescenta:

\footnotetext{
${ }^{173}$ SILVA 1950, apud CAMPOS, 2002, p. 50

${ }^{174}$ PASIN 2000, apud CAMPOS, 2002, p. 51
} 
Isto provocou graves conseqüências para a sociedade caipira, cujos sítios eram frutos de ocupação, muitas vezes por seus antepassados. Os caboclos, analfabetos na sua grande maioria, desconheciam qualquer tipo de trâmite burocrático necessário para legalização daquilo que, por sucessão familiar e pela tradição do antigo direito consuetudinário medieval, sempre foi considerado como seu. Embora continuasse a existir grande número de pequenas propriedades, a posição de seus donos tornou-se subalterna, a medida em que a riqueza do município, trazida pelo café, se concentrava nas mãos dos grandes proprietários. $^{175}$

Não se faz necessário muito esforço para compreender o sistema de distinção classista impresso neste processo. Porém queremos chamar a atenção para o fato de que não é somente o enfraquecimento de uma economia familiar baseada nas pequenas produções que resulta deste processo, mas também um deslocamento do eixo da compreensão dos sensos de propriedade e de reciprocidade com o meio, uma vez que passa a ser exigido uma concessão legal para o uso da terra: "Pequenos donos de terras foram expulsos e desenvolveu-se uma aristocracia rural dominante, quer econômica, quer social, quer politicamente." ${ }^{176}$ Acreditamos poder admitir a este pondo que muito freqüentemente, uma sociedade que tenha em suas base históricas este tipo de transição de uma sociedade de direitos consuetudinários como o conteúdo das relações materiais, (o trabalho obedece muito mais os ritmos da própria natureza do que da produção), para uma sociedade de hegemonia aristocrática e fragmentária, privilégio não somente do Brasil, mas das nações desenvolvidas a partir dos processo civilizatórios da colonização, estejam revendo suas bases culturais civilizatórias.

Antes de passarmos as raízes daquelas formas culturais de manifestação expressiva, identificamos na pesquisa de Campos, (2002), as categorias dentre as quais ao menos três prestaram a composição daquelas formas de expressão, são elas,

[...] o fazendeiro, dono de um latifúndio, onde predominava a monocultura de exportação; o sitiante, que continuava produzindo a costumeira agricultura de subsistência, com alguns produtos excedentes para o mercado; o agregado, que residia dentro das fazendas, ocupando, como parceiro ou meeiro, parte

\footnotetext{
${ }^{175}$ FAORO, 2000, apud CAMPOS, 2002, p. 53

${ }^{176}$ CAMPOS, Op. cit., p. 54
} 
das terras com lavouras e criações; e o camarada, que era um empregado, sem vínculo empregatício, geralmente recebendo como diarista. ${ }^{177}$

Com exceção do fazendeiro que pertencia à classe dos mais abastados nesta nova economia, às ultimas três categorias de cidadãos podemos atribuir as subjetivações capazes de dar origem a modos culturais, pelo fato de conservarem as atividades laborais com a terra, e isto os ligarem aos antepassados das diferentes etnias, por permanecerem alijados dos novos propósitos políticos expansionistas ditados pelo acumulo de bens como já havia acontecido com os caipiras e pelo fato de que, muito provavelmente se conservava entre estes últimos a convicção de que a riqueza ainda se expressava com mais veemência nas construções coletivas:

Enquanto isso, os agregados ou moradores das fazendas reelaboraram seus costumes, embora carentes de suas próprias bases: a livre disposição da terra e a participação em pequenos grupos sociais coesos. Conseguiram se acomodar à sombra das grandes fazendas e reeditar o seu modo tradicional de subsistir, produzindo o que necessitavam, escapando assim, ao destino de assalariado. ${ }^{178}$

Quando se pretende evidenciar a presença da ideologia deve se afunilar o foco sobre as próprias capacidades, dentre as que mais se evidenciam está a ideologia política, no entanto uma busca incessante por auto-preservação também deve corresponder a uma força ou conjunto de forças que diferenciam na forma como se concentram, neste caso por uma convergência natural, uma vontade coletiva com interesses coletivos, oposto a vontade coletiva com interesses individuais.

Jogo Fechado e Jogo Aberto - Partimos da assim proposta classificação intencionando analisar a participação do sujeito humano nas formas expressivas. Chamamos jogo ao momento de socialização através de uma manifestação lúdica; qualificamos como fechado ou aberto a forma de organização do grupo na expressão popular. A Dança do Moçambique é um exemplo do primeiro tipo de organização, pois depende de uma liderança

\footnotetext{
177 Ibid., p. 55

178 Id., p.55
} 
(mestre e contra-mestre), normalmente a cargo de um componente mais experiente, que conhece os bailados, as cantorias e os manejos. É também a pessoa encarregada de transmitir aos mais novos este conhecimento. Esta organização fechada corresponde ao número de dançadores na linha, para que os manejos possam ser executados de forma completa. São necessários os ensaios e praticamente nada é improvisado durante a função. Assim, o Jongo, que para este trabalho serviu de observatório, é exemplo da forma aberta de jogo. Para esta modalidade não são necessários ensaio, nem um grupo formado. Não se faz sem pelo menos alguma noção, que pode se obter a um primeiro contato. Contudo o ponto, ou seja, o canto depende de certo aprofundamento na prática. São chamados galos velhos, os mais experimentados. São estes que tomam da anguáia, espécie de chocalho, quando vai colocar seu ponto. Além dos que tocam tambús (dois ou três tambores), homens e mulheres formam a roda e participam do canto repetindo o complemento final do verso em forma de resposta, enquanto o jongueiro repete a parte anterior.

A época da escravidão, o poder opressor exercido pelo Senhor branco contra o negro escravo poderia ser extremamente violento. Poderia custar a vida de todo o grupo. Enquanto modo de comunicação cifrada em linguagem própria, o jongo foi utilizado para burlar as intervenções opressoras dos senhores brancos.

Nesse ponto, entendemos que não somente o ato de jogar, transmissão, o ponto é um fenômeno utilizado como estratégia que permita garantir alguma possibilidade de liberdade dentro do grupo, mas a reunião das pessoas, a roda e os ajustes formam todo seu arcabouço estratégico. ${ }^{179}$

Pelas provas materiais da época escravagista podemos calcular a violência no trato com a fuga, a desobediência etc. No entanto não se pode desconsiderar que o escravo era um bem capital, o que justificaria prejuízo para o Senhor o extermínio de todo um grupo. Não cremos também na intencionalidade direta de burlar a opressão do Senhor. Com este tipo de abordagem deixa-se em

\footnotetext{
${ }^{179}$ ALENTEJO, Eduardo da Silva. Memórias dos Jongueiros do Tamandaré: estratégias de permanência, institucionalização da cultura popular e suas relações de poder. Trabalho de conclusão de Curso (Mestrado em Memória Social e Documento). Universidade do Rio de Janeiro, Centro de Ciências Humanas e Sociais, Rio de Janeiro, 2005, p. 37
} 
segundo plano as subjetividades próprias daquelas relações. Não somente no que diz respeito ao senhor e ao escravo, mas entre os escravos, pela etnia, pela ancestralidade, por suas relações materiais (trabalho, ferramentas, instrumentos etc.). Contudo, consideramos no postulado acima a linguagem cifrada e a possibilidade de liberdade como sendo as razões em si da forma de expressão. Na modalidade de Jongo examinada, certas peculiaridades chamaram a atenção. Dentre elas, a distinção entre um Jongo de Visaria quando os pontos versam sobre coisas amenas e o que entendemos no trabalho de campo como Grumento* (ou ainda, gorimento, glorimento, grusmento). Neste ultimo caso, como contam os entrevistados, o que seria apenas um desafio amistoso, vai ao patamar de confronto com forças místicas, com um dos jongueiros sendo subjugado pelo, se assim podemos dizer, mais poderoso. Chegando este último a impingir ao mais fraco, alguns distúrbios fisiológicos e até morais. "Num outro momento, o jongo temido pelos moradores como prática de feitiçaria não é alvo de perseguição porque isso é somente um sentido, o jongo estaria ligado a tradições religiosas se não católicas, mas com forte cruzamento religioso, como é o caso da Umbanda"180. O ponto sempre é tirado de algo que está próximo (um detalhe do ambiente, o Santo festejado na ocasião, alguma ocorrência inusitada etc.), mas tem de ser travado, isto é, decifrá-lo é o desafio e a empreita é de quem pega. Enquanto permanece um ponto sem ser decifrado diz-se chora angôma. E, para o jongueiro colocar seu ponto ele anuncia: cachoeira. ${ }^{181}$

Considerando os elementos culturais étnicos, o bairro com suas festas e, o nexo dialético entre as dimensões trabalho e festa - a segunda é o fim da primeira sem objetivamente extingui-la -, queremos analisar diferentes aspectos da interação do indivíduo com a forma de manifestação em si. Partimos também do pressuposto de que todo o transcorrer da vida, mediante as transformações sociais, que antecederam a formação daquela expressão complementa o impulso ideológico que não se defende na retórica, mas na expressão, em uma espécie de crônica narrativa popular - e viva.

\footnotetext{
* Esta palavra não consta do dicionário Novo Aurélio $3^{\mathrm{a}}$ edição, onde o termo mais aproximado refere-se ao verbo grumar.

${ }^{180}$ ALENTEJO, Op. cit., p. 38

${ }^{181}$ Entrevista concedida a este pesquisador em São Luiz do Paraitinga no dia 14/02/2009
} 
O Moçambique é um bailado ${ }^{182}$ do qual a origem muitos estudos não sabem precisar, mas relacionando o nome com o país africano, julgam ser esta a origem, mas não se atribui especificamente a bagagem cultural dos escravizados.

[...] É uma dança guerreira, muito antiga. Na Inglaterra é conhecida por morris dance. Pode ter sido praticada pelos mouros na península Ibérica e não foi difícil ao conquistador português, aproveitá-la na catequese o Brasil como precioso fator de recreação popular. ${ }^{183}$

Uma vez que estamos tratando das raízes históricas é preciso que se atente para a pragmaticidade e funcionalidade do verbete acima transcrito. Diz o que é e para o que serviu e também indica indiretamente em que lugar do conhecimento deve ser colocado, ou seja, distante de qualquer práxis. Com base no pensamento de Gramsci (1966) é histórica, porém não historicista. Mediante esta visão, torna-se quase impossível atribuir a esta forma de manifestação da cultura própria um princípio de força social. Pelo que julgamos serem as bases de formação das manifestações em foco aqui, não se pode deixar que seja desconsiderado tudo que se abatia sobre as classes subalternas e como esta se articulava política, econômica e filosoficamente, sendo que os recursos tinham que ser criados. Entretanto, assim se configura o método do patrimonialismo identitário nacional:

No bailado do Moçambique existem varias danças. A parte dramática é insignificante. As danças têm nomes religiosos: Escada de São Benedito, Estrela da Guia etc.

A confraria dos moçambiqueiros e mais folclórica do que a das congadas. A maior parte dos participantes é jovem.

O regulamento é oral e normas simples criadas pelos grupos que dirigem as Companhias de São Benedito.

Para dançar usam bastões de madeira, que são batidos como espada. Saltam e evoluem em uma coreografia complicada sob o comando do tarol (caixinha de guerra), reco-reco, pandeiro, rabeca, tamborins, violas.

Cantam louvações religiosas

\footnotetext{
${ }^{182}$ BRASIL, Histórias costumes e lendas - São Paulo: Ed Brasil21 Ltda, 2004, p.79. Ver também informacões disponíveis em ‘http://www.rosanevolpatto.tro. br. dancamocambique.htm->i <http://www.terrabrasileira.net/folclore/regiôes/5ritmos/mog.inbig.htmlì

${ }^{183}$ Ibid., p. 79
} 
O Moçambique está em franco desenvolvimento. O ponto maior da presença do Moçambique é no Vale do Paraíba do Sul em São Paulo. Entretanto também é encontrado no Rio de Janeiro, Minas Gerais, Mato Grosso e Goiás. ${ }^{184}$

Estas são sem dúvida a concepção histórica, que durante muito tempo e ainda hoje circula em muitos meios acadêmicos e informações eletrônica. Contudo, é possível destacar destas sintetizadas noções em primeiro lugar a idéia de confraria, que pressupõe uma associação, em nossa abordagem, considerando as contingências dos bairros rurais estas associações se davam na abrangência do clã familiar. Para que fossem criadas, mesmo que oralmente regulamentos e normas simples era preciso que houvesse uma coesão. Chamamos jogo fechado à forma de organização política para a gestão do grupo desde o mestre aos dançadores da linha. Para que houvessem evoluções sincronizadas nos bailados e no manejo dos bastões era necessário o preparo e ensaio, tendo se em conta as distâncias entre fazendas e sítios da época, a organização do grupo era facilitada pelos vínculos na extensão da família. Ressaltamos a presença desta forma de manifestação expressiva da cultura popular subalterna no Vale do Paraíba corresponde diretamente às análises feitas anteriormente das circunstâncias históricas do desenvolvimento inicial desta região.

Quanto ao Jongo, outra forma de expressão da cultura popular subalterna da qual tratamos

[...] é uma Dança de origem africana, possivelmente do Povo oriundo de Angola, da qual participam homens e mulheres, possivelmente quer dizer divertimento. $\mathrm{O}$ canto tem o papel fundamental, associado aos instrumentos musicais e dança. Alguns pesquisadores classificam-no como um de "tipo de Samba" mais antigo, seria ele que daria mais tarde origem ao Samba. Em alguns locais o nome pode variar como Caxambu, Dança do Jongo, Bambelô, dentre outros. ${ }^{185}$

\footnotetext{
${ }^{184}$ Id., p. 79

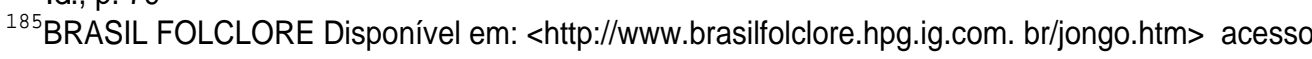
em:02/02/2009. Ver também < hittp://Lww.jongodaserrinha.org.brsi
} 
Quando os estudos abordam especificidades da cultura, na tentativa de se elaborar uma apreciação histórica, que no caso acima sintetizado, pelo tipo de mídia, podemos destacar os pontos mais evidentes: a suposta origem, a constituição e o que se desenvolveu, supostamente daquela forma ou depois dela. Muitos estudos mais sérios apresentarão certamente maior profundidade. Mas, considerando toda tecnologia aplicada à informação, levando se em conta que o conhecimento é algo ao qual se pode portar e também que a cultura tem representado um dos maiores entraves para o desenvolvimento das Ciências Humanas, tornam-se cada vez mais pertinentes os questionamentos a respeito da relação com a cultura.

Da forma como se tem feito, a cultura, mesmo como área do conhecimento, parece incluir o ser humano como elemento de sua constituição, completamente destituído de ideologia. Talvez por isso devamos correlacionar à desconexão do mundo do trabalho do mundo da cultura. Não raramente é possível se ouvir ao sabor do senso comum a expressão de certos profissionais: - trabalho com cultura. Cabe neste ponto a reflexão de Todorov (1993) "[...] o trabalho era tido como mais bem-feito na medida em que fosse mais 'objetivo', quer dizer, em que permitisse apagar qualquer traço do sujeito que eu era, ou os julgamentos de valores que eu pudesse carregar." ${ }^{186} \mathrm{Da}$ suposição da forma expressiva como divertimento, nasce a separação entre trabalho e laser. Não que a forma expressiva não servisse a este propósito; ainda muito mais, serviria certamente à elevação do espírito. Contudo, queremos despertar maior atenção para o fato de um estudo sobre as especificidades da cultura deve levar em conta a completa interconectibilidade entre trabalho e cultura. Dimensões que se interpenetram inicialmente pelos sensos de propriedade e reciprocidade. Enfatizamos que no momento da formulação de um modo expressivo, o contexto sócio-cultural compreende relações humanas e materiais e destas a utopia da ciência - a idéia:

Sozinhas, as idéias não fazem história, as forças sociais e econômicas também agem; mas as idéias não são apenas puro efeito passivo. De início tornam os atos possíveis; em seguida,

${ }^{186}$ TODOROV, Tzvetan. Nós e os Outros. Rio de Janeiro: Jorge Zahar Editor, 1993, p.11 
permitem que sejam aceitos: trata-se afinal de contas, de atos decisivos. $^{187}$

Voltando a descrição histórica do Jongo:

[...] É uma música feita para dançar, e fundamenta-se com o "ponto", ou seja, a pessoa tem que "desamarrar" (decifrar) o "ponto". O "ponto" seria uma espécie de adivinha, onde o verso cantado não expressa de forma muito clara o que se trata, e é preciso descobrir para saber do que fala a música. [...] $\mathrm{Na}$ maioria das vezes a música é cantada por duas vozes, ou três vozes. Em alguns locais é comum as pessoas participantes do Jongo dançarem ao redor dos instrumentos, noutros lugares dançam em frente aos instrumentos, sendo a que é uma dança de roda que se movimenta de forma contraria ao ponteiro do relógio (sentido anti-horário) coisa pouco comum, como passos para frente, pulos, giros etc. ${ }^{188}$

A esta descrição, acrescentamos uma particularidade das rodas de jongo pelo menos em alguma das situações observadas que a condição que aqui chamamos de jogo aberto. Lembramos que nosso objetivo inicialmente e analisar a participação dos indivíduos na forma de expressão com relação à dinâmica social vivida.

Na luta com o tempo e as mudanças de comportamento.

\footnotetext{
${ }^{187}$ TODOROV, op. cit. pp. $14-15$
}

${ }^{188}$ BRASIL FOLCLORE, Op. cit. 


\section{4 - Memória Coletiva, Memória Sensível e a Comunicação como Dispositivos Ideológicos}

A festa é sem dúvida fenômeno da comunicação. Tendo se em conta o fato de que ainda encontramos este de evento de socialização nas suas versões mais antiga, ou seja, que ainda não se moldaram por completo a linguagem pragmática da globalização cultural - a homogeneização; também pelo fato de que uma sociedade, por mais que estejam calcificados os modelos de comportamentos ditados pela a digitalização dos códigos e signos na corrente informatização do saber; e ainda, por mais que tenham se reduzido os motivos para as autênticas celebrações, é quase impossível imaginar uma sociedade sem a catarse festiva. Podemos afirmar, que por esta proposição que em se tratando da época em que as manifestações expressivas da cultura das quais tratamos, possivelmente tiveram origem a festa era certamente um dos momentos mais significativo dos encontros para comunicar e abastecer a memória coletiva. Cabe aqui com as palavras de Gramsci (1966), a crítica aos "intelectuais puros" de hoje, limitados em abarcar com a compreensão o quanto se faz importante e necessário, maiores aprofundamentos nos estudos sobre o fenômeno de expansão do turismo implicados à área da Comunicação. Os que não admitem tal implicação apenas conseguem exemplificar um pensamento funcionalista inconseqüente. As universidades que mantém curso de Turismo parecem não promover mais do que um como se comportar diante do turismo, imaginando-o como um fenômeno dominado por isso não haver necessidade de observação por mais argutos pesquisadores dos problemas da comunicação social.

O turismo tem sido a partir deste potencial comunicacional atributo das festas como fenômenos de convergência. Como deslocamento de grandes massas, obedecendo aos apelos midiáticos serve ao mercado da satisfação em pacotes. Não questionamos o turismo como atividade inerente ao ser humano, desde a condição de nômade. Chamamos a atenção, para a recorrente problemática das visões científicas fragmentárias que obstruem a concepção da comunicação, como princípio estimulador do turismo; dificilmente alguém guarda para si as experiências vividas em outro lugar. O problema é que este mesmo princípio funciona para acelerar a expansão desta prática. Também não criticamos a prática de se divulgar os pontos turísticos, porém não 
aceitamos os extremos, como o turismo sexual próprio da relação despótica do centro à periferia. Entendemos que o turismo se impulsiona com a potencialidade tecnológica aplicada à comunicação. A comunicação social está por todos os vieses implicada no desenvolvimento expansivo do turismo. Da mesma forma a comunicação, admitida como princípio de manutenção da cultura, é afetada pelo turismo massificado e homogeneizado. Assim não se deve deixar de considerar, portanto que estudá-lo não deve permanecer na margem estreita da rentabilidade e nem na perspicácia em transformar as coisas em objetos de adoração turística.

Devem persistir os questionamentos sobre quais as principais alterações no movimento das sociedades quando a comunicação humana deixa de ser o espírito primordial da festa, - uma vez que na festa tudo se expressa, - e se limita a ser mecanismo estratégico para circulação de mercadorias. Assim não seria cabível refletir sobre as relações humanas sem se ter em alta consideração que a "memória do indivíduo depende do seu relacionamento com a família, com a classe social, com a escola, a lgreja, com a profissão; enfim, com os grupos de convívio e os grupos de referência peculiares a esse indivíduo."189 À esta interdependência somamos os processos comunicacionais como fluído essencial de transporte do conteúdo memorial na escala do tempo. Torna-se claro, porém através deste esquema elementar (indivíduo-memóriacomunicação), que os conflitos geram sintomaticamente os deslocamentos; a memória deve armazenar a imagem dos conflitos, contudo estes últimos somente existem em função do embates de hegemonias no interior da sociedade, pressupõe-se assim consubstanciado o conteúdo da memória desta sociedade. "A menor alteração do ambiente atinge a qualidade íntima da memória. Por essa via, Halbwachs amarra a memória da pessoa à memória do grupo; e esta última à esfera maior da tradição, que é a memória coletiva de cada sociedade."190

A partir das reflexões acima, devemos a este ponto esclarecer a natureza do que queremos chamar de memória sensível; que a princípio conjecturamos como memória gravada no corpo - capaz de impregnar as relações materiais reforçando e justificando, por mais esta via, o que já postulamos como senso

\footnotetext{
${ }^{189}$ BOSI, Eclea. Memória e Sociedade: memória dos velhos. São Paulo, Companhia das Letras, 1994, p. 54 ${ }^{190}$ Ibid., p. 55
} 
de propriedade. Pode ser que não passemos de obviedades ao resvalarmos às questões da genética, porém sempre que adentrarmos o terreno das relações humanas defrontaremos certamente com as complexidades que designam possibilidades de modelos. É por isto mesmo hipotético, não é a pretensão do caminho da verdade, mas algumas pequenas incursões em esferas de onde se podem pressupor articulações e possíveis deslocamentos; Assim não se trata de comprovar ou não a existência desta memória sensível, mas de dar ênfases as predisposições fisiológicas que estão em relação direta com o ambiente e o meio (condições objetivas). Refere-se à possibilidade de alcançar maior reconhecimento da integralidade que se pode atingir desta relação; à conformação mais plena do humano genérico. Também não se resume em observar potencialidades físicas, mas do quanto somos modelados $\mathrm{e}$ modelamos nosso meio físico-sócio-cultural. Trata-se de mais um dos princípios dos processos de identificação. Como faculdade, a memória funciona de forma a lembrar o corpo, a acionar os dispositivos mecânicos sensoriais para a atividade ou para a representação.

Nem sempre, contudo, as sensações levadas ao cérebro são restituídas por este aos nervos e aos músculos que efetuam os movimentos do corpo, as suas ações. Nem sempre se cumpre o percurso de ida e volta pelo qual os estímulos externos chegam, pelos nervos aferentes, à central do cérebro, e desta voltam, pelos eferentes, à periferia do corpo. Quando o trajeto é só de ida, isto é, quando a imagem suscitada no cérebro permanece nele, 'parando' ou 'durando', teríamos, não mais o esquema imagem-cérebro-ação, mas o esquema imagem-cérebrorepresentação. [grifos da autora] $\mathrm{O}$ primeiro esquema é motor. O segundo é perceptivo. ${ }^{191}$

Podemos deduzir que o que se movimenta neste complexo esquema é que tanto ao que corresponde à ação quanto a representação é o poder edificante das subjetividades, de um lado impulsionam o sensorial-fisiológico, de outro a consciência. Lembrando-se que sensação, percepção e representação são segundo afirma Nazareth Ferreira (2006), formas de conhecimento.

Não pretendemos dimensionar as capacidades múltiplas da memória, simplesmente pelo fato de que poderia ser subdivida por cada parte ou

${ }^{191}$ lbid., p. 44 
sentidos do corpo; é uma matéria para outro estudo. Interessa-nos o fato de que por esta diversidade esta memória se recria secularmente no homem.

Apesar da diferença entre o processo que leva à ação e o processo que leva à percepção, um e outro dependem, fundamentalmente, de um esquema corporal que vive sempre no momento atual, imediato, e se realimenta desse mesmo presente em que se move o corpo em sua relação com o ambiente. ${ }^{192}$

Assim sendo, estamos mais uma vez abordando à esfera do trabalho, da atividade humana em geral, mas, mais especificamente dentro das relações de trabalho. Pois esta especificidade tem mais significativa correspondência com a organização da sociedade do que com as potencialidades individuais. Por este motivo acreditamos que a dissolução destas relações está em completa reciprocidade com a dissolução deste tipo de memória; o que em nosso entendimento tem corroborado para a ampliação do quadro de alienação cultural. Não vamos, contudo examinar o quanto estas dissoluções encadeadas tem nos afetado. Interessa antes, porém averiguar a pertinência da questão, quando o propósito é o de se chamar a atenção para um senso de propriedade. Consideremos a filha de um casal de sambistas que por um motivo qualquer desde a mais tenra infância passou a morar com os tios em uma região distante onde não tenha qualquer contato com aquela forma de expressão dos pais. Um dia aos 16 anos de idade, suponhamos, a menina se veja em um ambiente bastante apropriado e tenha nesta ocasião oportunidade de assistir a seus pais biológicos exibirem prazerosamente, seus passos. Acreditamos na possibilidade de que a atmosfera possa sensibilizar perceptiva e representativamente a adolescente por toda a sua compleição física e de sua consciência. Em poucas palavras, ressaltamos que pela situação simulada, estaríamos mais próximos da manutenção mais perene de um tipo de bailado no samba.

Acreditamos que um conjunto de estímulos envolvidos seja capaz de dinamizar uma espécie de identificação físico-sensorial que poderá detonar a vontade de movimentos similares além inclusive de uma identificação catártica. Não interessa afirmar se a adolescente, a partir daquele instante vai gostar ou não,

\footnotetext{
${ }^{192}$ Id., p. 44
} 
se adotará ou não aquela prática ou até mesmo se identificar ou não da forma como propomos, mas que vários elementos se reúnem para qualquer uma destas possibilidades ou todas juntas. Esta forma de considerar se opõe a proposição ideal de preservação de uma forma expressiva, somente por sua aparência e estética. O conceito de senso de propriedade é uma conduta que procura açambarcar o máximo das condições para que uma prática se preserve; sem dogmas, pela identificação. Por isso questionamos o período que os problemas tenham que permanecer problemáticos. A filosofia da práxis nas relações materiais, através do reconhecimento das contradições, dentro de uma metodologia mais abrangente das Ciências Humanas - a dialética resolve esta questão, pois ao invés de simplesmente servir de base parar desdobramentos teóricos empurra e reclama a ação. Questionamos o desafio da educação ao insistir na formação, ao renegar este tipo de memória. Pelo prisma das relações pedagógicas, imaginemos uma criança que tem oportunidade de observar em seu avô, um dançador de Moçambique, um trabalhador da inchada; consideremos que este mesmo garoto identifica as semelhanças expressivas do avô em seu pai; a maneira como arrastam os pés e fazem rodopios, certamente haverá identificação estético-sensorial, que pressupõe interatividade e reciprocidade no fazer - faço pela expressão que faz por mim. Mas não podemos fugir, contudo desta questão projetada à escala das relações em centros urbanos mais numerosos e mais complexos. Não é difícil confundir esta argumentação com a idéia fixa no senso comum de nascer para tal coisa ou tal pai, tal filho; sobretudo, quando com o foco desce sobre as relações de propriedade em reciprocidade na divisão social do trabalho. 0 trabalho, como o conhecimento, é uma totalidade que tem por propriedade consumir-se em sua própria substância. Interessa-nos que em todo o conjunto das praticas sócio-culturais, em torno e dentro destas relações, possa vigorar este senso de propriedade ou ao menos reconhecido. Por se tratar de uma linguagem pode ser lida.

Mas não se pode passar ao largo da imprescindibilidade de uma política sócioeconômica global (mais no sentido de abrangência do que no aspecto planetário) que possa dinamizar e expandir esta concepção e, se quisermos também que esta mesma concepção transcenda a ideologismos como onde se apregoar saídas. Reivindicamos reconhecimento para a potencialidade do 
particular e do universal da cultura e da comunicação como dispositivos essenciais deste processo.

A este ponto desperta-nos a atenção de que na sociedade ou no espírito de sociedade encontram completamente interconectadas como dimensões a memória sensível (ação e percepção no indivíduo), a memória coletiva (percepção e representação no coletivo), e a ação comunicativa que denota movimento no cotidiano.

Gramsci (1966) fazendo uma análise crítica à máxima de Kant sobre (sua) ética observa ser menos exata a objeção

[...] de que não existem "condições similares", já que entre as condições está compreendido aquele que atua, a sua individualidade etc. [...] Portanto, aquele que atua é o portador das "condições similares", ou seja, o criador delas: isto é, ele "deve" atuar segundo um "modelo" que gostaria de ver difundido entre todos os homens, segundo um tipo de civilização pelo advento da qual trabalha ou por cuja conservação "resiste" [grifo nosso] contra as forças desagregadoras, etc. ${ }^{193}$

Entretanto como orienta Bosi (2003), refletindo sob o "signo de Benjamin": abordando como exemplo a paixão vivida pela burguesia paulista na Revolução Constitucionalista de 1932:

É preciso sempre examinar matizando os laços que unem memória e ideologia. Laços que, antes da secularização moderna, amarravam a memória pública á memória individual.

[...] Há, portanto, uma memória coletiva (no caso, a produzida no interior de uma classe, mas com poder de difusão), a qual se alimenta de imagens, sentimentos, idéias e valores que dão identidade e permanência àquela classe. No caso, os interesses da burguesia do café acabaram envolvendo sentimentos regionais de paulistismo, que ainda hoje operam como fator discriminante em plena sociedade de massas, tal como veio a configurar-se a população da cidade de São Paulo. Mas não se pode negar que exista uma memória coletiva ${ }^{194}$

Ao rigor do alerta acima, devemos entender que a memória como dispositivo ideológico ou paixão da lembrança também serve de forma liberal aos

\footnotetext{
${ }^{193}$ GRAMSCI, Op. cit., p.60

${ }^{194}$ BOSI, Eclea. O tempo vivo da memória. São Paulo: Ateliê Editorial: 2003, pp. 22-23, passim
} 
interesses da dominação, não é necessário nem que se procurem exemplos. Por isso a necessidade de maior e mais precisa acuidade no tratamento de complexidades científicas humanas.

A Cidade e o Evento. Aqui consideramos a cidade, inicialmente como fenômeno da vontade coletiva. Mesmo que se considere que o homem possa optar por um relativo nomadismo ou cosmopolitismo, para a sociedade atual estas são apenas definições do espaço que se delimita com o simples uso do cartão de crédito. Devido ao fato de que nosso objeto de estudo esta plenamente em referência com a festa popular subalterna, a população de uma comunidade e envolvida direta ou indiretamente; objetivamente, pois a estrutura de uma cidade é colocada em funcionamento subdividindo-se as atribuições entre os poderes instituídos, mais o comercio e a sociedade civil; de outro lado, subjetivamente por que será daí extraído o motivo histórico para a festa. Este também passa a ser um fator de identificação desta comunidade mobilizada. Uma delimitação de esfera, porém significativa em nossa abordagem é a da cidade, por compreender um sistema de interação entre instituições e indivíduos identificados por territoriedade e personalidade. Neste sentido uma cidade, poderá realizar qualquer tipo de evento dito popular, porém de acordo com esta personalidade o evento terá seu significado midiático com respectiva abrangência. Aqui precisamos verificar ainda que de forma sucinta alguns procedimentos com os quais as cidades se preparam para eventos festivos, como se comportam durante as festas maiores e menores e como ficam depois do evento realizado; isto do ponto de vista da coletividade. Pode-se admitir que trata-se de uma suposta suspensão do cotidiano precedente a um período de preparações (coletas de donativos, organização e distribuição de tarefas etc.). A festa em si é o presente, mesmo que muito se repita tudo é novo a cada nova realização. Depois de realizada a festa a comunidade deve retomar o espaço nas atividades cotidianas. Para os valores investidos: os resgates.

Assim como no inicio os próprios bairros eram distintos por uma dinâmica sócio-cultural, da mesma forma a cidade carrega algumas identificações, inclusive no próprio nome; por uma disposição geológica (Areias- SP, por uma localização, (dos Montes, do Grotão); muitas vezes refere-se a um potencial natural, rio etc. Entretanto, conforme podemos analisar em uma sessão 
anterior, enquanto persistiu a concepção de bairro, mediante as mudanças ocorridas na historias dos deslocamentos e organização das sociedades, na medida da resistência também persistiram costumes e valores em consenso. $O$ mesmo se pode, em parte atribuir à cidade que seguindo, por exemplo, 0 desenvolvimento da indústria, umas em detrimento de outras se adornaram com ímpetos progressistas (pólo industrial, pólo turístico, cidade dormitório, cidade mictório etc.)

Em muitos casos, conforme uma personalidade original desde a formação dos bairros, algumas cidades tiveram que assumir uma postura em função da alternativa econômica e da possibilidade de geração de renda extra. Estas cidades por estes motivos (festa de Santo Padroeiro, Carnaval, Festa do Boi, festa de alguma fruta, etc.) atraíam visitantes antes mesmo de serem pólos turísticos. A promoção de determinados eventos passou a representar a oportunidade política de se fazer alguma coisa pela cidade.

Enquanto discutimos o desfacelamento dos ambientes de propriedade, 0 espaço/tempo que torna propício o espírito para o desenvolvimento das manifestações espontâneas; podemos assistir a outros fenômenos correspondentes como o da cidade nova (Nova Friburgo, Nova Conceição etc.), de cidade-fantasma e cidade vendida ${ }^{195}$. Dentre estes, chamamos a atenção para o qual damos o nome de cidade alugada ${ }^{196}$, que diretamente destitui 0 valor de uso da morada e se amplia a margem de valorização para a troca. Conforme a proporção do evento, muitos moradores descobriram a oportunidade de um adicional significativo à renda, alugando sua casa pelo período do evento festivo. Não nos encontramos aqui em posição de tecer critica a este novo nicho de mercado imobiliário, até por que como já dissemos o atrativo muitas vezes antecede o turístico. Contudo é uma circunstância que tende a se modificar na medida em que se for construindo novos hotéis e pousadas. Estamos falando sim de deslocamentos; paradoxalmente, a população responsável pelas características mais representativas de uma dada especificidade cultural se desloca (para casas de parentes, para os bairros

${ }^{195}$ CIDADE-fantasma no Texas é vendida por US $\$ 3$ milhões no eBay. Folha On Line, 24 nov 2007. BBC BRASIL Disponível em:<http://www1.folha.uol.com.br/folha/bbc/ult272u348264. html>.Acesso em: 13 fev. 2009.

${ }^{196}$ MAESTRLLI, M.; REHDER, Lyane. São Luiz do Paraitinga quer menos foliões em 2009. Disponível em <http://www.vidadeviajante.com.br/saoluiz-do-paraitinga-quer-menos-folioes-em-2009/> 
rurais, para outras cidades, para os balcões e serviços etc.), cedendo espaço para ser preenchido por uma população flutuante e bastante diversificada quanto à origem e os interesses. $E$, ainda mais, completamente estranha a cultura local.

Salientamos, no entanto que este tipo de convergência inventa ao seu fim uma espécie de comunidade instantânea se comparamos com os princípios fundadores do bairro; analisando do ponto de vista do outro que vem experimenta e vai embora:

Todos esses agentes, eventos e interesses servem como 'cabide' em que as aflições e preocupações experimentadas e enfrentadas individualmente são temporariamente penduradas por grande número de indivíduos - para serem retomadas em seguida e penduradas alhures: por essa razão as comunidades estéticas podem ser chamadas de 'comunidade-cabide',197

Esta mesma convergência não escapa de ser analisada por diversos prismas. Pelo prisma sociológico há o fator de migração pelo fato de que a cidade festiva e a princípio atrativa como morada. Entretanto, assim como analisamos do ponto de vista da festa como fenômeno da comunicação humana pela sua capacidade de transcender a caducidade do tempo unindo passado e presente, admitimos que este fenômeno mesmo possa, como já está acontecendo, assumir o status de mecanismo (neo)-liberal da concepção extremamente distorcida de crescimento.

${ }^{197}$ BAUMAN, Op. cit., p. 67 
This document was created with Win2PDF available at http://www.win2pdf.com.

The unregistered version of Win2PDF is for evaluation or non-commercial use only.

This page will not be added after purchasing Win2PDF. 


\section{CAPÍTULO 3}

\section{FESTA - AMBIENTE DA CONVERGÊNCIA}

\subsection{Festa Popular Subalterna}

O popular da festa é logicamente o popular da cultura. Este caráter de popular está em intima conexão com as esferas do político, do econômico e do filosófico. Em muitos aspectos, porém, a concepção de cultura popular, a cultura das classes subalternas, encontra-se diferenciada da concepção da cultura que se transfere conforme um sistema de pré-estabelecimento de valores - a quem de direito; nestes casos são diferentes os critérios para o acesso à cultura. Uma das principais diferenças entre as duas concepções, ou entre estes critérios é o fato de que a primeira é franqueada à massa, mediante o seu próprio cotidiano, pois é ela mesma, a massa que produz a cultura; a segunda, cultura de massa, obedece a um sistema quantitativo de distribuição setorizado. Vale dizer que, quanto maior a produção em determinado setor, maior extensão da acessibilidade, mais pessoas com direito ao acesso e à possibilidade de se moldar individualmente ou em grupo uma identidade cultural como se-Ihe convier, (isto é, desde que disponível no mercado, pois mais dificilmente o indivíduo poderá optar por uma identificação com algum tipo 
de manifestação já extinta ou fora de moda, como uma língua arcaica, ou uma técnica agrícola artesanal etc., superadas pelo fator, estética ou pela praticidade e o ganhar tempo). Assim sendo, não é difícil incluir. No setor da cultura (de massa), o acesso à informação e respectivamente toda sorte de mídias correspondente, representa um dos últimos filões, e uma das mais avantajadas fatia para o apetite (neo)-liberal do capitalismo, ao lado das Indústrias automobilística, alimentícias e as monoculturas, ou seja, os maiores setores. As festas populares subalternas, como manifestação cultural, têm sido açambarcadas pelo consumismo midiático; esta conduta como uma estratégia culturalista - promove - difunde a cultura popular pelo conteúdo que dela possa se extrair para as experiências mais imediatas e, amiúde, as mais efêmeras. Deste conteúdo, exemplificando através de uma linguagem, destacamos a gama do que uma festa popular proporciona em termos de imagens. Consideremos o quanto é possível se explorar da reprodutibilidade tecnológica deste conteúdo imagético, a partir tão somente de um aparelho de telefone celular. Não está em questão nem a tecnologia, que avança em sentido óbvio, sempre a instrumentalizar a atividade humana; nem tampouco a linguagem, pois não se trata da análise teleologia sobre uma lógica formal, também não diz respeito especificamente à dinâmica do mercado de cultura (volume de circulação dos produtos da indústria cultural), pois a natureza do mercado se atualiza a cada novidade resgatada. Tratamos efetivamente dos modos de relação com a cultura e em seu interior, levando-se em conta um processo de consolidação histórica da cultura enquanto popular - ou seja, que tem origem na prática. Quando Gramsci (1966) em seu estudo sobre a "concepção dialética da historia", alerta para "alguns problemas para o estudo da filosofia da práxis" ${ }^{198 ;}$ o mesmo alerta é acatado aqui de maneira imprescindível, uma vez que o presente trabalho, entre os estudos pretendidos, nesta sessão, quer tratar de certa forma, do ambiente e do momento do "nascimento de uma concepção de mundo" - projetado à realidade do contexto atual de uma determinada historicidade (a saber, a das nações cuja formação sócio-econômica e cultural deveu-se aos movimentos de colonização impostos). O problema segundo o autor, cuja "explicação reside no próprio 
marxismo" se identifica binominalmente "como ciência e ação. Passagem da utopia à ciência e da ciência à ação."199 A questão que hora se apresenta é de se saber, quando exatamente uma filosofia especulativa nascida do senso comum se alça a uma concreta concepção de mundo. Quando que uma prática cotidiana, de tecnologia popular, uma ação (de um grupo subalterno) converte-se em ciência. Ao tratar das "questões do método"200, outra exigência é feita, quando o autor se refere à necessidade de se "efetuar preliminarmente um trabalho filológico minucioso"201, e, desde já, este trabalho não pode ainda pretender tamanha dignificação; mas, é preliminarmente uma tentativa de teorizar sobre a observação de um fenômeno social, e que pretende ser significativa na medida em que se intensifica o foco dos debates em torno das questões sobre a cultura. Gramsci (1966) exige com rigor, princípios de lealdade na postura do intelectual. É o que constatamos imediata e efetivamente ao tomarmos contato com a acuidade do autor com aquilo a que se prontifica fazer. Orienta sobre a metodologia no tratamento para com as obras do(s) pensador(es) de forma o mais abrangente e minuciosa, propondo uma reconstrução "por períodos cronológicos-críticos" e, no caso específico dos fundadores da filosofia da práxis (KARL MARX E FRIEDRICH ENGELS) 202, sobre o que seria "o estudo de um pensamento original e inovador"203, pelo que entendemos, a projeção de uma certa continuidade entre os autores, não de forma subseqüente, mas extensiva, ou seja "deve ser colocada a questão das relações de homogeneidade entre os dois" ${ }^{204}$. Esta questão, certamente se refere a todo o desenvolvimento conceitual subseqüente, pois é de certo rigor a postura crítica de Gramsci (1966) ao confrontar Georges Sorel e Rodolfo Mondolfo quanto á questão do "pensamento original" entre os dois fundadores da filosofia da práxis; contra Leon Bronstein em defesa de Antonio de Labriola que, "ao afirmar que a filosofia da práxis é independente de qualquer outra corrente filosófica, sendo auto-suficiente, foi o único a procurar construir

\footnotetext{
${ }^{199}$ lbid., p. 93

200 lbid., p. 94

${ }^{201}$ Id., p. 94

${ }^{202}$ Ibid., Pequeno Glossário.

203 lbid., p. 97

204 Id., p. 97
} 
cientificamente a filosofia da práxis."205 Gramsci (1966) ataca "a tendência dominante que se manifestou em duas correntes principais: a chamada ortodoxa"206, via pela qual a metodologia "positivista de Plekhanov"207, não suplanta "o materialismo vulgar"208 e, a outra corrente oriunda e oposta à primeira, culmina "na conclusão 'agnóstica' de Otto Bauer, [...] que afirma que o marxismo pode ser baseado e integrado por qualquer filosofia inclusive, portanto, pelo tomismo."209 Gramsci, ao questionar a "pouca sorte" que tivera Labriola na colocação do problema filosófico, lembra o dito de Rosa de Luxemburgo sobre a economia crítica e seus mais elevados problemas, no momento das reais autonomia e hegemonia de "um grupo subalterno [...] a exigência de elaborar os conceitos mais universais" ${ }^{210}$. Devemos entender e ter em mente que esta universalidade dos conceitos (além de pretender que estes conceitos possam se resumir na concepção de que, identificar a necessidade e reconhecer a possibilidade de transformação, aspira conjunta e dialeticamente à liberdade) está em completa correspondência com a autonomia atribuída a uma cultura superior, não por ser mais bem consubstanciada, aparelhada ou reluzente, mas é superior por que é a cultura que se faz; e, como hegemonia, que assim concluímos, não pode se referir a outra coisa senão ao sentido de universalidade (ou universalização). Se de um lado sua superioridade é distinta pela espontaneidade, criatividade, articulação etc. de outro, o sentido de universalidade a faz livre, extensiva, amalgâmica.

Vale lembrar que na historicidade de seus escritos, e não assegurar-lhe a atualidade é tremenda falácia; Gramsci (1966) alveja "as correntes que tentaram combinações da filosofia da práxis com tendências idealistas [...], constituídas em sua imensa maioria por intelectuais 'puros' e também a 'ortodoxia' formada em sua maioria por personalidades intelectuais [...] dedicadas às atividades práticas [...] mais ligadas às grandes massas populares"211. Os primeiros como "elaboradores das mais amplas ideologias

\footnotetext{
${ }^{205}$ Ibid., p. 98

${ }^{206}$ Ibid., p. 99

${ }^{207}$ PLEKHANOV, 1908 apud GRAMSCI 1966, p. 99

${ }^{208}$ GRAMSCI, Op. cit., p. 99

${ }^{209}$ Id., p. 99

${ }^{210}$ LUXEMBURGO, 1919 apud GRAMSCI, 1966, pp. 99-100

${ }^{211}$ GRAMSCI, op. cit. p. 101
} 
das classes dominantes; 'a tendência ortodoxa' por acreditar poder superar o 'transcendentalismo religioso' através tão somente do mais cru e banal materialismo"212. Ainda que com uma ressalva quanto à 'segurança', Gramsci (1966) faz distinção mais uma vez a Labriola, por afirmar "que a filosofia da práxis é uma filosofia independente e original, que possui em si os elementos de um ulterior desenvolvimento que a transforme, de interpretação da história, em filosofia geral." 213

Gramsci (1966) apenas nesta sessão em que trata de alguns problemas para o estudo da filosofia da práxis, dando exemplo da metodologia que ele mesmo propõe, desenvolve sua análise crítica dentro de certa cronologia, mas não de forma restritiva, sobre os fatos e a produção conceitual, ou o pensamento, compreendidos em uma periodização que se estende dos idos de 1789, marcados pela revolução francesa, aos anos trinta. Assim, evitando estender por demais as observações e restringindo as pontuações ao que estamos debatendo nesta sessão - formas de relação com cultura -, concordamos com toda a defesa que Gramsci (1966) faz da filosofia da práxis cujo "momento sintético unitário"214 conforme crê o autor deva

[...] ser identificado no novo conceito de imanência, elaborou sinteticamente os três movimentos, isto é toda a cultura da época, e que na nova síntese, em qualquer momento que se a examine, momento teórico, econômico ou político, se reencontra como 'momento' preparatório de cada um dos três movimentos. ${ }^{215}$

Empenhamo-nos até este ponto na iniciativa de respaldar, mediante a filosofia marxista de Antonio Gramsci (1966) a proposição sobre o que a festa popular tem de conexão com os campos político, a econômico e filosófico, e que por esta conexão, torna-se depositária do atributo de porta de acesso ao conteúdo

\footnotetext{
${ }^{212}$ Id., p. 101

${ }^{213}$ Id., p. 101

${ }^{214}$ Ibid., p. 110

${ }^{215}$ Id., p. 110. "Gramsci se baseia na afirmação de Lénine a respeito do nascimento da filosofia da práxis "sobre o terreno do máximo desenvolvimento da cultura da primeira metade do século XIX, cultura esta representada, em resumo, pela filosofia clássica alemã, pela economia clássica inglesa e pela literatura e prática política francesa."
} 
ideológico da cultura popular subalterna. Estabelecendo correspondência a respeito da conexão entre festa popular e economia, em outro ponto, Gramsci conjectura ser a filosofia da práxis igual à soma de Hegel com David Ricardo, este ultimo como o autor de novos cânones introduzidos na ciência econômica. Ao questionar sobre "um significado de inovação filosófica"216, destes novos cânones, sobre terem sido estes "a descoberta de valor também gnoseológico"217 e sobre a implicância de "uma nova 'imanência' uma nova concepção de 'necessidade' e de liberdade"218; Gramsci (1966) aponta para a filosofia da práxis como realizadora desta tradução (de cânones sistemáticos ao princípio de imanência) que teria universalizado as descobertas de Ricardo, estendendo-as adequadamente a toda história e extraindo delas, portanto, uma nova concepção das atividades deste campo. Todavia, Gramsci (1966) recomenda o estudo de uma série de questões relativas aos estudos de Ricardo, dentre as quais destacamos a seguinte explicação e sua respectiva fórmula:

(A economia estuda estas leis tendenciais enquanto expressões quantitativas dos fenômenos; na passagem da economia à história geral, o conceito de quantidade é integrado pelo de qualidade e pela dialética da quantidade que se transforma em qualidade) [Quantidade = necessidade; qualidade = liberdade]. ${ }^{219}$

Apresentando a "unidade dos elementos constitutivos do marxismo"220, que "é determinada pelo desenvolvimento dialético das contradições entre o homem e a matéria"221, Gramsci (1966) complementando, indica o valor como "o centro unitário"222 da economia. Ressaltamos para um entendimento preciso relacionado à cultura popular que valor e economia não aferem especificamente a movimentação monetária. $O$ valor pode ser concebido sem escalas comparativas e economia é arte e também é ciência. Quando

\footnotetext{
${ }^{216}$ Ibid., p. 111

${ }^{217}$ Id., p. 111

${ }^{218}$ Id., p. 111

${ }^{219}$ Ibid., p. 112

${ }^{220}$ Id., p. 112

${ }^{221}$ Id., p. 112

${ }^{222}$ Id., p. 112
} 
executamos um instrumento musical, principalmente quando este traz uma diversificada extensão de recursos para a produção do som, há uma economia dos movimentos adequada integralmente à linguagem, pode-se admitir que alguns gestos sejam de um rebuscado estético, mas não há certamente o que não tenha o seu lugar na execução. "Na filosofia este centro é a práxis,"223 que em nossa reflexão resolve pela organicidade o problema da relação entre ciência e ação. "Na política é a relação entre o Estado e a sociedade civil."224 Tal relação deve ser mediada pelo respeito à diferença de crença e opinião, mas pela pré-disposição equânime à responsabilidade. Há inevitavelmente, quem indague sobre o aspecto local projetado ao global, a comparação entre as dimensões festa, Estado e sociedade civil, entretanto é bastante clara a idéia, que o autor traz, ao elucidar as contradições dialéticas entre homem e natureza, de "vontade centralizada" ${ }^{225}$. Em nossa concepção a realização da festa deve ser a realização de uma vontade popular.

Não se faz necessário que se dimensione (contar em números, extensão e diversidade), esta esfera da vontade popular para determinar se em um dado momento estanque haja nela indícios de universalidade como que se quer do Estado enquanto democracia representativa. Até mesmo por que é uma tarefa inútil tentar destacar e descrever momentos estanques na dinâmica social do popular. De quando Gramsci (1966) ao bordar "hegemonia da cultura ocidental sobre toda cultura mundial"226, para dar uma idéia do conceito de universalidade conter e estar contido na dinâmica social do popular, por isso não ser possível abarcá-lo de um único golpe de vista, nem ao menos em um momento estanque, destacamos que "o que é importante é o nascimento de uma nova maneira de conceber o homem e o mundo, bem como o fato desta concepção não mais ser reservada aos grandes intelectuais, mas tender a se tornar popular, de massa, com caráter concretamente mundial, modificando o pensamento popular, a mumificada cultura popular."227 Ressaltamos que tornar o conhecimento de massa é diametralmente oposto a se produzir cultura de

\footnotetext{
${ }^{223}$ Id., p. 112

${ }^{224}$ Id., p. 112

${ }^{225}$ Id., p. 112

${ }^{226}$ Ibid., p. 126.

227 lbid., p. 127.
} 
massa. No primeiro caso trata-se de instrumentalização e articulação e o segundo de passividade e dominação. Mas acima de tudo é o tornar-se popular que não permite sua captura e síntese. No impulso utópico de enfrentar esta empreitada, ninguém está imune a aforismos e muito pior desvanecimento, num eco infinito, de muitas filosofias (especulativas) e teorias. Nas notas e ao final desta sessão, quando Gramsci (1966) volta a bombardear com críticas mais incisivas, em especial o antijacobinismo de George Sorel e o pedantismo de Henri De Man encontramos orientações que nos permitem retirar protetores e véus que delimitam e turvam a visão. A partir destas críticas é possível se refletir sobre em que ponto se colocar, para melhor noção do quanto é possível para a metodologia abarcar o objeto. Diz respeito ao trabalho do pensador. Desta premissa, alçamos a distinção que o autor faz em tendo como pano de fundo histórico os anos de "1870 e 1871, [...] na França, as duas terríveis derrotas: a nacional, que pesou sobre os intelectuais burgueses; e a popular, a derrota da Comuna que pesou sobre os intelectuais revolucionários." "228 Não é difícil identificar os reflexos destas duas versões do intelectual nos dias de hoje, o reflexo da primeira continua enquadrado na tarefa de elaborar para o Estado o aparato científico e ideológico de dominação - controle - sobre a dinâmica popular; e o segundo continua, em oposição ao Estado, postado na confrontação conceitual de ideologias de onde não se admite a grandeza política do sujeito social popular, sendo que dele não se aproxima, exceto em momentos de aclamação ou em calamidades públicas. Quando chamamos a atenção para o problema dos modos de relação com a cultura enfatizamos que acessá-la ou portá-la refere-se a uma modalidade de aproximação que contradiz a idéia aqui apresentada de movimento de convergência, neste caso atribuído a festa; esta aproximação está em contraposição ao afastamento necessário que a metodologia indica para definição ou identificação de um problema. Este afastamento, por sua vez contradiz dialeticamente a inerência orgânica fundamental que deve existir entre o intelectual e sua própria cultura popular. Assim sendo, convergência não é de forma restrita o seguir as setas para um centro e sim o sentido de correntes que chocam gerando movimentos diversos em diversas direções - irradia. Mas, é importante acrescentar que ${ }^{228}$ Ibid., p. 132. 
neste movimento muitas correntes anulam-se entre si, pois tem argumentos frágeis e impulsos débeis; outras, porém são capazes de absorver ou se somam o que torna mais hegemônica sua atuação nos confrontos. Neste jogo de correntes - ideologias e contra-discurso -, o capitalismo se transformou numa grande força e no sentido contrário de sua rota deve vir outra força proporcionalmente oposta. Esta força capaz de negar o princípio do capital é a negação do valor enquanto valor de troca. Acreditamos que tal negação somente exista quando alguma coisa é feita ou dada de graça. Poderá se argumentar que esta conduta passe de simples formalidade para o bem estar cotidiano ou regras formais da sociedade, benevolência. Mas para a festa popular esta conduta é um princípio. Outros esbravejarão perguntando como vai se gerar emprego e renda para alimentar a multidão de pobres? A resposta para esta pergunta certamente estará muito menos entre as subjetividades do mundo do trabalho do que na formulação da ideologia neoliberal que domina e controla a divisão social do trabalho.

Seguindo com as criticas de Gramsci (1966) a Georges Sorel,

[...] havia muito diletantismo, muito "jamais empenhar-se a fundo" e, portanto, muita irresponsabilidade intrínseca nas atitudes políticas de Sorel, que não eram jamais estritamente políticas, mas "culturais-políticas", "intelectuais-políticas", au dessus de la mêlée. ${ }^{229}$

Apontando suas setas agudas para o pedantismo de De Man, na sua "pretensão de lançar a luz, e em primeiro plano, sobre os chamados 'valores psicológicos e éticos' do movimento operário"230, Gramsci (1966) apresenta entre outras a seguinte questão:

[...] A filosofia da práxis sustenta que os homens adquirem consciência de sua posição social no terreno das ideologias; ela exclui o povo por acaso, deste modo de tomar consciência de $\mathrm{si}^{231}$

Mediante a questão apresentada pelo autor, podemos definir os modos de relação com a cultura e em seu interior, não como pensar sobre ou para a

\footnotetext{
${ }^{229}$ Id., p. 132 "acima do conflito"

${ }^{230}$ Ibid., p. 134

${ }^{231}$ Id., p.134
} 
cultura, mas sim um modo cultural de construir o pensamento. "A tarefa de toda iniciativa histórica é modificar as fases culturais precedentes, tornar a cultura homogênea, em um nível superior ao precedente, etc." ${ }^{232}$, queremos crer que por cultura homogênea deve se entender expansão do perímetro social abarcado pelos conhecimentos mais recentes e asseverados por levar à autonomia transformadora e libertadora, mas não como a homogeneização da cultura conforme os nivelamentos estratificados pela quantidade/oportunidade de acesso a informação.

É interessante notar que Gramsci (1966), em sua rigorosa acuidade ao abordar sincronicamente cada pensamento, cada autor, não descarta de pronto e terminantemente suas doutrinas negativas (positivismo, pragmatismo, idealismo, funcionalismo, metafísica, est.); habilmente demonstra como se extrai, através da crítica, o que houver de positivo ou profundo daquele pensamento. Não somente destrói as argumentações tautológicas que não levam a coisa alguma. Pensamos, neste sentido que, a falta de reconhecimento de um horizonte, mesmo que utópico, de uma autonomia da multidão ${ }^{233}$, permita externamente a chegada dos impulsos de condução, indução e do controle.

Assim, ao falarmos do modo de relação coma a cultura e em seu interior, queremos dizer que, quem pretender observar o caráter de popular da festa, observará, portanto, o ambiente popular da cultura que cria este momento, ou seja, o modo pelo qual a cultura produz e se auto-reproduz através de objetividades e subjetividades. Por isso mesmo, mais um sinal de alerta se destaca, correspondente a um desvio recorrente na formação do intelectual. Contra seus ultimo alvos nesta sessão, Gramsci ataca, desvelando além de seu pedantismo, o filistinismo e o sectarismo de Henry De Man, apontando que:

[...] o erro do intelectual consiste em acreditar que se possa saber sem compreender e, principalmente, sem sentir e estar apaixonado (não só pelo saber em si, mas também pelo objeto do saber), isto é, em acreditar que o intelectual possa ser um

\footnotetext{
${ }^{232}$ Id., p. 134

${ }^{233}$ HARDT; NEGRI, Op. cit., p.289
} 
intelectual (e não um mero pedante) mesmo quando distinto e destacado do povo-nação, ou seja, sem sentir as paixões elementares do povo, compreendendo-as e, assim, explicando-as e justificando-as em determinada situação histórica, bem como as relacionando dialeticamente às leis da história, a uma concepção do mundo superior, científica e coerentemente elaborada, que é o saber; não se faz política-história sem esta paixão, isto é, sem esta conexão sentimental entre intelectuais e povo-nação. ${ }^{234}$

As atitudes de acesso e portabilidade do intelectual sobre o objeto são vias livres para uma paixão superficial. O arrebatamento desta paixão cria um deslumbramento qualquer que o conduz às sistematizações mais gerais e distanciadas. Desta forma "as relações do intelectual com o povo-nação são, ou se reduzem, a relação de natureza puramente burocrática e formal; os intelectuais se tornam uma casta ou sacerdócio" consultados pelas dirigentes das classes dominantes sobre quais as saídas para as questões sobre a cultura:

Se a relação entre intelectuais e povo-nação, entre dirigentes e dirigidos, entre governantes e governados, se estabelece graças a uma adesão orgânica, na qual o sentimento-paixão torna-se compreensão e, desta forma, saber (não de uma maneira mecânica, mas vivencialmente), só então a relação é de representação, ocorrendo a troca de elementos individuais entre governantes e governados, entre dirigentes e dirigidos, isto é, realiza-se a vida do conjunto, a única que é força social. ${ }^{235}$

Podemos argumentar que, o quanto, com as lentes do intelectual formalburocrata se pode abarcar do objeto, além de não significar vivência do fenômeno, não corresponde de maneira alguma à adesão orgânica e muito menos a compreensão, como sendo um sentimento-paixão, como quer o autor. Observamos, neste arrebatamento que, o sentimento que amiúde envolve o intelectual das Ciências Sociais e das Ciências Humanas deva ser o sentimento popular. Pois, tratando das relações humanas é em si apaixonante; em seu funcionamento, se percebido de dentro é força - uma efusão de forças. Percebido de fora é singelo, telúrico etc., apenas formal.

${ }^{234}$ GRAMSCI, Op. cit., p. 139
${ }^{235}$ Id., p. 139 
De Man "estuda" os sentimentos populares; não concorda com eles para dirigi-los e conduzi-los a uma catarse de civilização moderna: sua posição é semelhante à do estudioso do "folclore", que teme continuamente que a modernidade lhe destrua o objeto da sua ciência. ${ }^{236}$

Para que possamos atingir a representatividade de um fenômeno, como no caso a festa, em relação às atividades do homem, pelas quais julgamos suas capacidades de conhecer para transformar, faz-se necessário tomá-lo dentro dos aspectos mais significativos da cultura, ou, pela sua pertinência na forma de concepção do mundo; não apenas como uma noção, mas em uma atitude de apreensão. Assim considerado, neste aspecto, a festa, como afirma Maria Nazareth Ferreira (2005), na pesquisa realizada sobre as festas populares na Itália, e da mesma forma como adotamos aqui, é um "instrumento privilegiado para o entendimento dos fenômenos da comunicação" ${ }^{237}$; chamamos a atenção para o que pode demonstrar, neste instrumento, as possibilidades de reconhecer, em correspondência com a cultura enquanto totalidade das relações entre o homem e a natureza, os mecanismos de sustentabilidade desta relação - entendendo que somente o virtualismo - é em parte capaz de suspender esta relação, pois não suspende a consciência.

[...] atualmente estas manifestações projetam no cenário da pósmodernidade toda a força de suas raízes, as quais, sobrepondo-se aos limites da liturgia e da fé católica, identificam as verdadeiras faces da cultura como prática cotidiana e como expressão comunicativa. ${ }^{238}$

Uma vez em busca de um dimensionamento dos potenciais dos modos culturais que dão sustentabilidade àquela relação homem/meio, deve-se, então respeitar no exposto acima, o que se anuncia como força de suas raízes e verdadeiras faces da cultura. Correspondente ao que neste momento é o

\footnotetext{
${ }^{236}$ Id., p. 139

${ }^{237}$ FERREIRA, Maria Nazareth, As Festas Populares na Expansão do Turismo: a experiência italiana Arte e Ciência. São Paulo, 2005, p. 23.

${ }^{238}$ Ibid., p.24
} 
objeto em questão, com o objetivo de identificar a origem comum desta força e destas faces, recorremos neste ponto, ao que Maria Nazareth Ferreira (2005) destaca do trabalho de Vittorio Lanternari (Festa, carisma, apocalisse. Palermo, Sellerio, 1989);

1) o sentimento da festa; o que faz com que a festa exprima um atmosfera intensamente participativa, densa de conotação simbólica e mítica, desenvolvendo uma função imediata e coletivamente catártica;"

2) A institucionalização da festa; cada festa comporta uma organização comunitária e uma regulamentação da parte do grupo festivo, que é mais ou menos amplo ou complexo. Neste componente organizacional entra o quadro de referência ideológico anteposto à festa e que segundo o caso, se refere a um mito de origem ritual ou simbolicamente reatualizado, à lenda de fundamentação de um culto; à imagem de um santo cristão; à um momento crítico da existência ou a um evento histórico, social ou político, que deve ser comemorado e reevocado, para renovar o impulso de vencer os percalços da cotidianidade através do fenômeno festivo. ${ }^{239}$

Partindo destas imprescindíveis concepções, tornam-se possíveis as abordagens, primeiramente no que correspondem às dimensões subjetivas ligadas as acepções interpretativas na história humana. Entendemos por esta via, que dos fatos históricos cotidianos resultem a partir da cultura, as interpretações míticas, simbólicas ou realísticas e, a partir da força ou capacidade de inerência ao cotidiano, seja possível entre outras possibilidades, revivenciar uma determinada índole comportamental que situe em determinado tempo histórico, a relação do homem com seus iguais e com os objetos de seu meio. Acreditamos que ao se revivenciar, através da festa, uma conquista histórica representativa, por exemplo, seja possível uma demonstração desta índole, não somente para efeitos visuais do contexto, mas também para um reconhecimento memorial. Em segundo lugar, merecem destaque as proposições objetivas identificadas como um quadro de referência ideológico. Neste caso, além da referência a um mito, um santo, ou a um momento histórico, entendemos que deva ser respeitada uma carga ideológica significativa, capaz de transpor a causalidade e elevar à historicidade um dado

${ }^{239}$ Ibid., pp.24-25 
momento. Atualmente, como exemplos recentes desta carga ideológica atribuída a um movimento objetivo, pode-se citar entre outras, no Brasil as comemorações do Dia da Consciência Negra e na Bolívia, o que poderá vir a ser uma data comemorativa, a aprovação por plebiscito de reformulações na constituição federal, que entre outras medidas estabelece cotas de participação de representantes dos povos autóctones no senado ${ }^{240}$. O que se argumenta aqui é que as circunstâncias são marcantes pela ideologia, ou pelo confronto de ideologias, e marcam exatamente por que certa hegemonia se faz a consenso. Aquele fato, mito ou ser, passa a representar determinado grupo cuja ideologia foi contemplada no ato. $A$ isto devemos acrescentar que, para ter se tornado motivo de celebração, (apesar de que em algumas celebrações haja rituais lúgubres), ainda se constata os princípios de cooperação, união, solidariedade etc., pois uma festa, diferente de um ímpeto de felicidade, nunca pode ser de um único individuo e o motivo nunca é vazio de ideologia. A partir deste pressuposto devemos enfatizar dois aspectos bastante significativos que conferem validade aos componentes políticos, econômicos e filosóficos da festa, enquanto um mecanismo sócio-cultural de manutenção das relações humanas:

O primeiro deles é a capacidade que a festa tem de trazer para a atualidade, desde longínquas épocas, as experiências culturais vivenciadas por determinada população; o segundo aspecto refere-se ao fato de que, mesmo contrariando as práticas intencionalmente concebidas no momento da festa, os usos e costumes mais profundos vivenciados pela cotidianidade e entranhados no inconsciente afloram, mostrando a verdadeira face de um povo, moldada através da cultura. $^{241}$

Considerando-se estes aspectos, ao menos três processos dinâmicos podem ser destacados: a identificação que assegura a vida em sociedade, a comunicação como sistema da cultura, e a articulação entre passado e presente, movimento pelo qual se faz a história.

${ }^{240}$ CABRERA LEMUZ, Adalid. El soberano Le dijo Sí a la nueva Constituicón. Rebelion. Bolívia: 27-01-2009 Disponivel em Lhttp://www.rebelion.or/noticia.php?id=7977 y acesso em 27/01/2009.

${ }^{241}$ FERREIRA, Op. cit., p.26 
Tratando da primeira dinâmica, não raramente tomamos a perspectiva de quem se identifica; tratamos evidentemente do indivíduo, de nós mesmo; mas ao tomarmos a perspectiva daquilo com o que se podem identificar como os valores, as crenças, usos e costumes; torna-se mais imediata a percepção de que a festa promove complementações dialéticas entre um tempo e um nãotempo, uma descontinuidade orgânica (social). Ou seja, as manifestações se realizam em uma evasão da cotidianidade, não que se interrompa a cronologia para posterior retomada, mas que no período de uma festa é possível alçar outros tempos, até as origens. Neste processo da identificação, outra complementação dialética se dá a respeito das condutas, ser em relação ao fazer, da perspectiva do que foi feito, remontando às origens da celebração, e do que está para ser feito, como rememoração do passado; as atividades, atitudes e condutas, também remetem a uma índole comportamental de um tempo remoto; por uns momentos o indivíduo se permite guiar por aquele espírito. Com toda "materialidade do ser - a força de sua existência social"242 assume um paradoxo espaço-temporal de ser e agir em uma inversão da realidade. A possibilidade de tomar contato com experiências culturais de outra ordem, de outro tempo e circunstância, pode como pensamos, permitir uma compreensão global do desenvolvimento humano. É desta inversão da realidade que se verifica uma terceira complementação dialética, a do espelho. Não obstante a imagem refletida parecer perfeita, o reflexo invertido mostra as distorções, a perspectiva refletida é impenetrável devido à própria materialidade do espelho e se colocamos um espelho defronte a outro de modo que um reflita ao outro dá-se uma infinita replicabilidade da imagem.

Com a reflexão acima não se pretende exatamente tecer críticas a perspectiva da festa como um espelho através do qual o indivíduo busca explicações para os percalços da sua existência. Ao contrário, com esta abordagem tentamos compreender o que Maria Nazareth Ferreira (2005) chama de "caos mítico primordial:"243

A festa reproduz simbolicamente a condição do caos mítico primordial, quando promove a anulação do presente. Assim, a festa é um simbólico retorno às origens - uma origem muitas

${ }^{242}$ Ibid., p. 28

243 lbid., p. 29 
vezes imaginária ou reinterpretada - necessário para garantir a integridade do indivíduo.

Por outro lado, a festa possui uma dupla contraditória potencialização entre conservação e criatividade cultural. De um lado empurra o indivíduo à fuga, à evasão da realidade banal, do cotidiano, para mergulhar no momento mágico da festa, que é também o momento do sagrado e do caos primordial. Esta evasão é provocada pelas técnicas que constituem a parte essencial da instituição festiva: o riso, o jogo, a dança, a música, a alegria, o descontrole orgiástico, o dramático etc. ${ }^{244}$

Corresponde à segunda dinâmica apresentada acima, a afirmativa de que a comunicação humana é propriamente a cultura. Não pode haver sociedade sem comunicação. À medida que o homem reconhece e desenvolve sistemas através dos quais transmite a outro, uma técnica, um saber, ou simplesmente um modo de relacionamento, estabelece conjuntamente um sistema de garantia de persistência daquele modo. Este sistema garantidor que reflete a reciprocidade entre cultura e comunicação, coloca estas duas dimensões em também em complementaridade mutua. Portanto, enquanto se desenrola esta parte essencial da instituição festiva, entra em atividade este sistema potencialidade inquebrantável, indefectível - da persistência histórica. É possível então, se admitir a este ponto que, a comunicação participa diretamente na articulação entre passado e presente quando atua incorporando novos valores aos tradicionais. A comunicação, ao se atribuir a dimensão de fenômeno da convergência à festa, atua como fenômeno de magnetismo imanente, pois de outra forma não existiria a história, sendo que esta somente existe pela intenção de ser comunicada, transmitida:

Disto se deduz a importância que tem o 'momento cultural' também na atividade prática (coletiva): todo ato histórico não pode deixar de ser realizado pelo 'homem coletivo', isto é, ele pressupõe a obtenção de uma unidade 'cultural social' pela qual uma multiplicidade de vontades desagregadas, com fins heterogêneos, se solidificam na busca de um mesmo fim sobre a base de uma idêntica e comum concepção de mundo (geral e particular, atuante transitoriamente - por meio de emoção - ou permanentemente, de modo que a base intelectual esteja tão

${ }^{244}$ Id., p. 29 
radicada, assimilada e vivida que possa se transformar em paixão). ${ }^{245}$

Da proposição gramsciana concebe-se a relevância historicista da festa com relação ao cotidiano. Assim, a terceira dinâmica se refere a um confronto dialético entre momentos culturais do passado com vontades desagregadas do presente, de cujo choque se produz um impulso que desloca a cotidianidade para frente. Da concepção gramsciana, relacionando-se as três dinâmicas interconectadas com o devenir histórico, pode-se deduzir inclusive a capacidade pedagógica da festa:

Toda relação de 'hegemonia' é necessariamente uma relação pedagógica, que se verifica não apenas no interior de uma nação, entre as diversas forças que a compõem, mas em todo campo internacional mundial, entre conjuntos de civilizações nacionais e continentais. ${ }^{246}$

Chegamos assim, a um conceito de universalidade atribuído à festa. Dos aspectos destacados (político, econômico e filosófico), da diversidade das abordagens possíveis, e da atemporalidade, conclui-se que acima e antes da validade da festa como objeto de estudo ela é o próprio estudo. As dinâmicas anteriormente apresentadas transformam-se facilmente em princípios pedagógicos. Porém, não interessa apenas enfatizar mais este dimensionamento do fenômeno festivo. Trata-se da concepção da festa como mecanismo estratégico para constante revisão das práxis cotidianas. Por isso também, a necessidade de maior acuidade a respeito da possível perda deste mecanismo pelos desvios ideológicos (neo)-liberais que, pouco a pouco transformam a historicidade deste ambiente cultural, em mumificações convenientes à atração turística.

Há muito temos aprendido que, quando se percebe uma convergência de interesses sobre determinado fato ou assunto, é por que problemáticas ali são evidentes ou constatáveis. Não será sem motivo que, se intensifique o foco sobre o fenômeno festa, acima de tudo, quando é iminente o confronto de

\footnotetext{
${ }^{245}$ GRAMSCl, Op. cit., pp. 36-37

${ }^{246}$ Ibid., p. 37
} 
ideologias. Havemos de admitir que a festa não seja tão somente um momento privilegiado para observação e possível compreensão antropológica das identidades, das precariedades humanas frente à vida etc.; trata-se de tudo isto e mais a concepção da festa como fenômeno da convergência, no sentido de que ela passa a ser cenário do entrave entre a concepção ideológica (neo)liberal de mercantilização do mundo e a possibilidade de se conferir os potenciais e a capacidade orgânica; de reconhecer e de reproduzir as circunstâncias primordiais dos reais avanços. Por estes potenciais e capacidade do que chamaremos deslocamento histórico positivo, confere-se a negação do homem como unidade estática e passiva e edifica-o como unidade subjetiva que dá sentido ao próprio deslocamento em contraposição ao esquema de rentabilidade - justificando o progresso.

É este o cenário onde se pode consolidar a interatividade orgânica do intelectual, diante da atualidade dinâmica da cultura popular subalterna, sendo que uma gama significativa do interesse pelo fenômeno festa é acadêmica, portanto trata-se de uma oportunidade histórica. Intelectual orgânico e cultura popular subalterna - "uma dialética intelectuais-massa"247 -, são aspectos da convergência. Antes dissociados pela incongruência falaz de uma instrumentalização política que pretende hegemonizar ainda, a distinção entre uma cultura de elite e uma cultura popular, agora, interconectados pela força social do próprio popular.

A partir destes aspectos projetam-se outras concepções dialéticas fundamentais na compreensão deste cenário do confronto das hegemonias, mundo-mercado e cultura-conhecimento:

À dialética entre reprodução/inversão, junta-se a dialética entre tradição/inovação, indispensável elemento dinâmico dos processos culturais. Por outro lado, a dialética entre tradição/inovação, apesar de ser um elemento interno à festa, num sentido mais amplo, reconduz - como a dialética entre a reprodução/inversão - a relação entre o festivo e o cotidiano. Compreende outro conjunto de elementos interativos, de modificação, de sincretismo e de criatividade, os quais constituem o produto visível no interior da festa; do dinamismo

${ }^{247}$ Ibid., p.22 
e das relações que se desenvolvem entre o contexto e a festa em si mesma ${ }^{248}$

Subentende-se por estas proposições, que exista um sólido e consistente sistema de produção/reprodução cultural, mais do que característico, próprio do povo; e, que tem por elementares o conhecimento histórico e a atualidade cotidiana. Elementos estes que, quando colocados em interatividade, representam os consensos de propriedade e de reciprocidade, pelo poder de envolver em um espaço/tempo delimitado, o cotidiano, pessoas e as coisas. $\mathrm{Na}$ preparação da festa, o exame das possibilidades, uma tomada global de atitudes e procedimentos capazes de uma predição, de um estudo. $\mathrm{Na}$ execução, a práxis fundindo teoria e prática. E, na ideologia - o cotidiano -, a história, a experiência de releituras dinâmicas impulsionadoras do movimento. Todo este sistema, que se representa por condutas ou comportamentos, não pode ser aleatoriamente tomado e nem depois de "alterado para se tornar entretenimento, deve ser preparado para consumo fácil." ${ }^{249}$ São inclusive, diversos os organismos que fazem esta preparação da festa, escolas, empresas de entretenimento, o poder publico nas três esferas (município, estado e federação) etc., no entanto, é o povo (autêntico produtor da cultura popular subalterna) que permanece na condição de produtor e consumidor, conforme a classe a qual pertença determinado extrato da sociedade, será correspondente a quantidade e a qualidade do acesso a este movimento, ou sua implicância direta. Se de um lado temos o conceito de acessibilidade, como o aspecto quantitativo da produção/distribuição - criação da demanda; de outro temos o conceito de portabilidade, que faz deste conteúdo, uma pasta de arquivos reprodutíveis, portáveis e transferíveis - satisfação e liberdade que cria num átimo, um falso e fortuito senso de reciprocidade - a experiência idealista de propriedade sobre a cultura. Vemos com tanta nitidez e tanta riqueza de detalhes, as cores; podemos, portanto, deduzir que quanto mais multifacetado é este mosaico, maior a possibilidade de generalização; vemos tanto, em um só golpe de visão, no sentido explicitamente global da imagem, que simplesmente perdemos de vista ou desconsideramos quaisquer reais

\footnotetext{
${ }^{248}$ FERREIRA, Op. cit., p. 30

${ }^{249}$ ARENDT, Op. cit., p. 259
} 
possibilidades da produção de conhecimento implícita nestas circunstâncias, servirem a propósitos políticos, econômicos e filosóficos de transformação da sociedade. Não importa por hora, questionar com respeito a estas atitudes, ou seja, do quanto podemos ver o predomínio da imagem ou do fascínio por ela ser o maior apelo, mas sim sobre o significado de popular como lugar fecundo. Tomemos a reflexão de Gramsci (1966) para expressar como grandeza a qualidade de popular:

Todo filosofo está - e não pode deixar de estar - convencido de expressar a unidade do espírito humano, isto é, a unidade da historia e da natureza; de fato, se uma tal convicção não existisse, os homens não achariam, não criariam uma nova história, isto é, as filosofias não poderiam transformar-se em 'ideologias', não poderiam assumir na prática a granítica e fanática solidez das 'crenças populares', que têm a mesma energia das forças materiais. ${ }^{250}$

O que existe de espontâneo na manifestação popular, corresponde às propriedades essenciais da matéria; falam às ciências, podem ser lidas, ouvidas e falam as compreensões humanas (na sua totalidade) servindo às transformações sociais. Cremos não ser necessário abrir algum debate ao postulado de Gramsci (1966), mas, em especial para que possamos melhor apurar nossa argumentação, devemos destacar os qualificativos, granítica $e$ fanática solidez, em seu pensamento (até mesmo pela expressividade fonética da língua), para começarmos a dar conta da potencialidade do popular. A festa popular se carrega inexoravelmente, da mesma energia material, seja pelo que compõe todo seu universo estrutural, objetivo e subjetivo, seja por representar cultura. E, quando afirmamos a conexão da festa popular subalterna com as esferas (do político, do econômico, do filosófico), apontadas desde o inicio da reflexão, e a "convertibilidade de uma na outra"251, acreditamos poder nos referir, em especial, às subjetividades edificantes da grandeza (da consciência) popular (de mundo). Acreditamos poder atribuir à festa a qualidade de portal de acesso a este universo estrutural e nele apreender, mediante a historicidade, sua concretude - o nexo dialético entre trabalho e festa.

\footnotetext{
${ }^{250}$ GRAMSCI. Op. cit., p. 114

${ }^{251}$ Ibid., p. 113
} 
O acesso informativo, como sinônimo ou atributo da cultura, permite ao indivíduo condição para portá-la, porém não contê-la, permite por atitude, obtêla sem que dela se aproprie. Aqui se revela uma contradição, ao ter-se que admitir que os conceitos de acessibilidade e de portabilidade referentes ao fluxo informacional, interfaces da cultura de massa, pressuponham, ao seu ambiente (cultura da tecnologia a serviço da satisfação), também uma relação de propriedade. Não é incorreto incluir, entre as manifestações da cultura transnacionalizada estes procedimentos. Disso decorre que, a cultura independente do ponto de vista pelo qual a abordamos, traz em si esta relação como princípio. Em outras palavras, podemos afirmar que, muito acima do que se possa representar (identidade), ou apresentar (de consumível) a partir da cultura, a ela interessa a relação de propriedade. Isto é, somente com uma marca mais profunda da experiência cultural é que poderemos comprovar empiricamente esta relação, e não a partir de um contato superficial, fortuito, por mais que este contato seja suficiente para a captura. Não queremos com essa afirmação estabelecer que somente quem viva esta relação possa fruir de um fenômeno como o da festa; o objetivo aqui, analisando a perspectiva de estudo sobre este fenômeno, a postura do pesquisador e mesmo a respeito dos efeitos mais positivos da festa sobre quem dela participe, é de se evidenciar a necessidade de uma dialética entre distanciamento e aproximação a partir da qual se constate as verdadeiras dimensões do espírito festivo, a ideologia da festa

De acordo com este acesso a cultura, como um dos aspectos do culturalismo da cultura regulada -, a festa talvez seja um dos últimos se não o ultimo dos alvos da cultura popular subalterna a ser atingido pela onda (neo)-liberal do capitalismo. Um dos últimos, pois devido à amplitude e contingência histórica de sua base popular, ainda não convinha àquela onda como oportunidade de mercado. Se em dado momento constatou-se que este fenômeno anexava-se á possibilidade de afirmação da identidade nacional cultural, hoje, ao contrario observamos em definitivo a diluição do espaço de sua construção.

Antes desta inversão comemorava-se o que seria fruto de determinada ideologia, de determinada época; as celebrações populares subalternas sagradas ou profanas passaram a corresponder ao calendário religioso cristão. 
"Entretanto, sendo, como eram manifestações profundamente enraizadas nas práticas cotidianas da população, não restou outra alternativa à Igreja que incorporá-las a sua Liturgia." 252

Temos tradicionalmente no Brasil e na America Latina, as festas populares subalternas em sua grande maioria apropriadas pela Igreja Católica, que mesclou expressividade popular com auto de fé. Também é preciso admitir que, por esta mescla bem sedimentada, desde a participação dos jesuítas na deformação de uma cultura (modos e línguas), para a formação de outra, foi também até aqui, responsável pela grande convergência dos adeptos. Mas não há espaço nem tempo para permanecer neste embate com a religião. Interessa mais que possamos, entre outros objetivos admissíveis, incluí-la entre os dispositivos de análise de problemáticas da ordem social. Assim, a festa popular subalterna, ao conjugar em seu dinamismo histórico um sistema comunicacional alimentado pela desenvolução constante e permanente da cultura, redistribui no plano irregular da cotidianidade possíveis processos (re)construtores da identificação como "uma necessidade de reação ao mundo contemporâneo, onde os contornos identitários estão cada vez mais indefinidos" 253

Há pelo menos três aspectos importantes para uma análise do que identificamos acima como absorção da festa pelo fenômeno global. Um primeiro caso é o de instrumentalização, tudo que se refere ao poder de envolvência da festa, desde o marketing, a logística até a partilha. Neste primeiro aspecto a comunicação é o elemento fundamental. Tanto no que corresponde a manutenção dos costumes quanto na perspectiva da dimensão do evento.

Os - sujeitos -, atores que em se tratando de festa popular, compreende entre todos os envolvidos, a massa; não somente por pressupor consumo, pois a festa não deixa de ter como um dos objetivos a arrecadação, mas pela vivência. A massa também não pode ser contextualizada somente como público. A massa popular na festa subalterna se compõe de atores que

\footnotetext{
${ }^{252}$ FERREIRA, Op. cit., p. 24

${ }^{253}$ Ibid., p. 28
} 
reciprocamente, se consubstancia no ambiente. Dá o colorido, o burburinho e, acima de tudo congrega interesses diversos em convergência. $O$ acesso ao fenômeno the é franqueado. A massa é convidada. A esta vivência correspondem a comportamentos como os de vibração, característicos festa popular.

Existem pelo menos três significativas instâncias através das quais podemos examinar posturas políticas não dimensionadas na festa como fenômeno e ambiente. Ressaltando-se antes, porém que são prontificações, a princípio espontâneas. Uma delas refere-se a quem importa a realização da festa, a do festeiro. A festa pode ocorrer como uma realização inusitada, sem uma organização previa. A comemoração a um título ou a conquista de um prêmio. Porém, a festa popular quando adota um sistema cíclico de realização, isto é, quando passa a integrar um calendário festivo de certa comunidade, passa também a considerar em sua organização um responsável, uma pessoa ou grupo de pessoas a quem caberá preparar, realizar e prestar conta à comunidade dos gastos e do lucro obtido.

Os folgazões; empregamos esta terminologia por tratar-se, inicialmente, de pessoas e grupos organizados sob alguma forma expressiva de manifestação que participam da festa com intuito da complementação estética do evento. São os que representam toda parte lúdica da festa e a quem inclusive se dirige nossa abordagem de forma mais específica, uma vez que esperamos comprovar em parte, nesta segunda instância, assim como em outras, um conteúdo ideológico nesta participação. É importante frisar que, além da classificação como atrativos da festa, estas formas de manifestação eram antes um gesto espontâneo, não cabendo a elas nenhuma forma de obrigação. A terceira instância diz respeito à massa. Esta é até certo ponto indefinível, exceto quando se-Ihe confere o status de público. Mas enquanto sujeito, atua e se predispõe às negociações próprias do contexto, ou seja, uma predisposição didática em relação ao aspecto qualitativo de todo conteúdo da festa popular. Esta predisposição pressupõe, por sua vez, o comportamento das pessoas correspondente a todo desenvolvimento do evento. Isto é, comportamento este que evolui conforme o que a festa oferece. Temos visto em muitos casos, que objetivamente, propostas de eventos festivos têm obedecido à égide da 
concentração de pessoas. Ou seja, atrações de renome (artistas cujos nomes têm veiculação televisiva) são contratadas para atrair maior número de pessoas. Postulamos que, ideologicamente, o sujeito massa no contexto da festa popular subalterna, não deve se restringir a esta concepção (de publico). Como entendemos aqui, a concepção de massa na historicidade do fenômeno festivo, correspondem efetivamente às razões pelas quais uma festa torna-se representativa das relações humanas, conforme o seu modo de produção. Este momento, não somente comemora ou celebra um motivo. Demarca inclusive, originalmente, pela forma como se comemora ou celebra o espírito destas relações. Diferente de se mostrar e de se ver, conforme a tendência da linguagem usada acima como exemplo, a festa popular propõe que se compartilhem todas as vivências; nada é sacralizado ao ponto de se impossibilitar o acesso de quem quer que seja. Neste caso a massa não é passiva nem submissa; como sujeito político, compõe, a seu turno as relações de troca simbólica no interior da festa. Desta forma, em uma próxima edição do evento, a massa comparece a fim de repetir o exercício.

Talvez possamos identificar como ideologia intrínseca da massa, a que faz com que a festa seja popular. De maneira extrínseca, (neo)-liberal, culturalista somente se consegue fazer de uma festa popular um evento que visa apenas à aglomeração, o acúmulo de pessoas desconsiderando suas singularidades.

Ao abordarmos a Ideologia das manifestações culturais populares, não estamos tão empenhados em provar a existência da ideologia nesta dimensão, nem examinar sua substância e sua aplicabilidade, o quanto estamos interessados na questão do posicionamento das orientações sociais diante desta ideologia; ao contrapô-la nega-se a matriz de transformação do ingrediente popular (a necessidade); ao se admiti-la, nega-se o fluxo de estratificações na passagem do popular para o de massa. 


\section{2 - Espaço de Negociações}

Em todo o contexto do fenômeno festivo, dos preparativos ao desfecho, se encontram em negociação, a satisfação, o espaço, o acesso, a história, a propriedade, a socialização etc. Chamamos negociação, partindo do pressuposto de que cada indivíduo que comparece, traz consigo anseios e explicitações. Neste momento, mesmo havendo um programa que determina certa ordem, todo o espaço físico e de tempo são predestinados ao espírito de festa. Todo o cotidiano compreende-se neste espírito, cada indivíduo, cada casa ou espaço pode assumi-lo e ampliá-lo. Antes de dar continuidade à análise, devemos anunciar que para o desenvolvimento desta sessão, incluímos as reflexões sobre as respostas colhidas em trabalho de campo cujas contribuições mais contundentes estarão em destaque. Respostas estas que foram colhidas junto a um dos elementos-chave da festa popular como apresentado anteriormente. O festeiro (podendo ser uma pessoa ou grupo de pessoas) é uma espécie de administrador da festa, que ao final do evento deverá prestar contas, no caso das festas religiosas, à Igreja. Independente disto, é a instancia encarregada de realizar a festa. O festeiro pode ser indicado ou escolhido pela comunidade representada pela Paróquia ou por uma associação de amigos de bairro, mas pode também se prontificar a sê10. ${ }^{254}$ Estará então encarregado de arrecadar as prendas, organizar, convidar; abrir e fechar o evento passando para outro a empreitada do próximo ano. ${ }^{255}$ Ao nos referirmos ao festeiro como administrador, não se pode confundir com outro tipo de administrador como, por exemplo, em relação à cidade, o prefeito que não rara e politicamente, faz festa para si. Para o festeiro a festa do povo. ${ }^{256}$

Voltando à negociação. De que forma ocorre esta negociação? Quais são as partes envolvidas? O que determina os valores para a troca? Não há como, ao final calcular os dividendos desta relação de troca dentro do espírito mais amplo da festa, uma vez que os valores do quais tratamos são incomensuráveis. A nosso ver a festa não pode nunca centralizar-se em um

\footnotetext{
${ }^{254}$ Entrevista concedida a este pesquisador em São Luiz do Paraitinga no dia 09/02/2009

${ }^{255}$ Id., São Luiz do Paraitinga no dia 09/02/2009

${ }^{256}$ Id., São Luiz do Paraitinga no dia 09/02/2009
} 
único interesse ou uns mais do que outros; como espaço de negociação ela deve ser o espaço dos interesses. Também, não se resume em que as questões sociais sejam debatidas e deliberadas em ambiente de festa. Até poderia ser, se assim observássemos a realização dos últimos FSM; no entanto, como espaço de negociação, como comunidade instantânea, na festa popular subalterna a oferta é a de seu senso de democracia. Importante ter em mente que, nesta consideração a negociação possa sobrepor o que se refere às hegemonias dominantes no contexto das festas, hoje. O lucro para o comércio, para a Igreja e o prestígio para o poder político, têm sido molas fundamentais na realização de eventos. Assim, quando partimos do pressuposto de que as manifestações culturais próprias do ambiente e da cotidianidade do bairro, foram preparadas para, inicialmente, servir de embelezamento da festa. Sem este barulho de alegria a amplitude do espírito festivo não se realiza. ${ }^{257}$ Por isso fazer parte das incumbências do festeiro trazer as Companhias de Moçambique, de Congadas e de outras danças. Merece destaque a este ponto que, de inicio estas Companhias compareciam espontaneamente, pela satisfação e pela devoção. O festeiro pode também contribuir com o transporte e a alimentação. ${ }^{258}$ Há hoje uma grande dependência de ajuda para este tipo de participação nas festas. Por esta dependência passa a vigorar outro jogo de interesses; tanto para o comércio como para o poder publico municipal, interessam mais os eventos que atraiam mais público. Cai por terra a idéia de espaço de explicitação ou de ambiente e oportunidade no que se refere às manifestações expressivas, pois as intenções são mais exclusivistas. Contrapõe-se a isto, o fato de que os bairros (rurais) intercambiavam com estas manifestações. Ou seja, conforme a celebração, de cada bairro, saem grupos que preencherão o ambiente do bairro em festa. Todo mês de novembro um grupo de cavaleiros vai buscar a imagem de Nossa Senhora das Grotas, no bairro das Grotas no município de São Luiz do Paraitinga, para uma novena na Paróquia de São Vicente, nos bairro dos

${ }^{257}$ Id., São Luiz do Paraitinga no dia 09/02/2009
${ }^{258}$ Id., São Luiz do Paraitinga no dia 09/02/2009 
Alvarenga, no mesmo município. A tradição garante chuva para o período de plantação de milho e feijão. ${ }^{259}$

Está em negociação o desejo. Dois são os pontos de vista do festeiro em relação à massa que freqüenta a festa. $O$ primeiro é que o evento deve contemplar a expectativa desta massa, uma vez que ela já fez experiências de satisfação anteriores naquele mesmo tipo de ocasião. Ou seja, o próximo evento nunca deve ser menos completo que o anterior. Com relação à presença das manifestações na festa, cada realização traz consigo a tradição: se um festeiro chamou a atenção do povo para aquilo e o povo gostou; isto serve para determinar que o procedimento deva ser repetido. ${ }^{260}$

De outro ponto, o festeiro se obriga a oferecer no programa os espaços para cada tipo de manifestação. Isto é, deve saber conciliar seu orçamento com a predisposição com que as Companhias de danças populares, se assim convém chamá-las, se apresentam. Contudo, não se trata exatamente de regra geral esta conciliação; a incumbência ou a vontade do festeiro são também conflitantes e, não raramente a tradição, com facilidade é modificada. Portanto, a festa é motivo de deslocamento de grandes ou pequenas massas atraídas para circunstâncias quase exclusivamente de interação. Tendo em vista que ainda hoje, são fenômenos bastante constantes, pode-se concluir que estes anseios, no mais das vezes são atendidos. Por esta proposição, a festa tem um fim em si, - atrair, pois, para que se realize. Mais do que consideração às tradições ou ao prestígio, o termo que mais amplamente consegue refletir 0 significado dos conteúdos que se negociam é respeito. ${ }^{261}$ Que é quando $o$ festeiro ou realizador supera os interesses mais exclusivos e contempla ao máximo os aspectos da composição da festa. ${ }^{262}$ Salientamos que deste respeito depende a diversidade e a dimensão do evento e o quanto será significativo para a experiência geral. Respeito este que confere a cada elemento, importância relativa a estas dimensão e diversidade, pois que todos os elementos trabalham sob o signo da beleza, da grandiosidade da festa. Tal respeito, peculiaridade do povo, corresponde inequivocamente ao que temos

\footnotetext{
${ }^{259}$ Entrevista concedida a este pesquisador em São Luiz do Paraitinga no dia 12/09/2009

${ }^{260}$ Entrevista concedida a este pesquisador em São Luiz do Paraitinga em 10/02/2009

${ }^{261}$ Entrevista concedida a este pesquisador em São Luiz do Paraitinga em 09/02/2009

${ }^{262}$ Id., São Luiz do Paraitinga no dia 09/02/2009
} 
chamado neste trabalho de sensos de reciprocidade e de propriedade. Uma idéia de se articular com os recursos que estão ao alcance das mãos. Cabe neste ínterim, uma observação, sobre a consideração particular de quem realiza a festa popular. Um festeiro pode não se interessar pelas manifestações culturais próprias. ${ }^{263}$ Conforme seu ponto de vista ou a que ele represente, sob a concepção de que o elemento do Moçambique não sabe ao certo onde termina sua religião e onde começa o "folclore", a celebração poderá prescindir de boa parte das manifestações, especial e premeditadamente preparadas para estas circunstâncias. ${ }^{264}$ Entendemos que, considerando o movimento de auto-reprodução da sociedade, estas manifestações com facilidade assimilam a religiosidade. O mesmo não se pode dizer do caso contrario. Observamos que em alguns casos é com certa resistência que a Igreja incorpora aos seus ritos de fé, as manifestações espontâneas, mesmo que estas sejam igualmente ritos de fé. Ou seja, melhor que como parte profana da celebração, permaneça no espaço que the cabe, de embelezar e atrair. Uma vez que as manifestações expressivas da cultura e mesmo a festa como seu ambiente de explicitação podem perfeitamente, e o fizeram, ao assimilar a religiosidade, queremos argumentar se nestes processos, outras prerrogativas também não seriam assimiláveis, como por exemplo, o que poderia ser explorado como valor gnoseológico do que se refere ao político, ao econômico e filosófico das atividades humanas. Perguntamos se como evento de convergência e espaço de negociações, não poderíamos aí debater, a respeito das subjetividades e da produção cultural ao mesmo tempo em que estamos inseridos na experiência, em pleno desenvolvimento.

Neste ponto entram em negociação também as explicitações. Estivemos explorando este termo, ao longo das reflexões pelo fato de estar em completa contradição com alienação.

"Deve se afirmar, antes de mais nada, que alienação é sempre alienação em face de alguma coisa e, mais precisamente, em face das possibilidades

\footnotetext{
${ }^{263}$ Id., São Luiz do Paraitinga no dia 09/02/2009

${ }^{264}$ Id., São Luiz do Paraitinga no dia 09/02/2009
} 
concretas de desenvolvimento genérico da humanidade." ${ }^{265}$ Devemos considerar que explicitação reflete plenamente o desenvolvimento daquelas experiências em todas e quaisquer qualidades. Pressupondo-se que esta experiência jamais se dá, no contexto da festa, de forma individualizada; que a explicitação prevê sempre a participação de outro, isto é, uma conduta de socialização; podemos afirmar seguramente que, apesar de temporário e efusivo, a festa pode ser elevada a categoria de momento catártico e de reflexão. Não nos referimos menos ao seu conteúdo do que a todo processo de preparação e realização. Todos esses momentos somados criam um universo de intenções que traduzem de uma forma ou de outra, parte da sociologia humana. Considerar esta tradução depende muito mais de se avaliar as posturas de inserção ou de intervenção, do que a aplicação de um sistema de análises que demonstre 0 funcionamento de cada elemento na contextualização destes fenômenos. Isto é depende da consideração ao valor de uso da festa, bastante ainda representativo.

Portanto ressalta-se nas festas populares subalternas, a dimensão da diversidade em correspondência com da universalidade. A perspectiva de suas possibilidades e de sua abrangência tanto quanto para o que é lúdico, quanto também para o que é lúcido. Criação e distribuição dos espaços. Este é um dos aspectos da diversidade/universalidade, tendo em vista 0 atendimento as expectativas. Haja visto que, é crescente o interesse dos cursos universitários das áreas de Sociologia, Comunicação, Turismo e outras, pelo tema, festas populares.

Por esta via de abordagem está claro que passou a existir quase que uma postura de exploração (de fora) das festas. Naquelas que são de caráter religioso e mesmo e outros casos, um motivo é oferecido em negociação, um santo, uma data, uma conquista. Mas, pode ser também um investimento, para quem visa se beneficiar política e economicamente. ${ }^{266}$

Por estas práticas, a ideologia da festa torna-se encoberta. Os sujeitos, com seus espaços delimitados e demonstrativos, apagam-se. Evidencia-se o processo de alienação cultural. As manifestações próprias têm intuitos não

\footnotetext{
${ }^{265}$ HELLER, Op. cit., p.37

${ }^{266}$ Entrevista concedida a este pesquisador em São Luiz do Paraitinga em 10/02/2009
} 
declarados, porém excludentes, entre o que serve ou não aos propósitos lucrativos. Oposto á concepção da festa para quem a faz. Mas, não para quem a promove. Não está em apreciação qualquer equilíbrio que se possa alcançar no movimento oscilatório dos interesses. Mesmo por que, assim acreditamos, somente quando hegemonias confrontam-se é que podem surgir novas orientações. Importa, porém a possibilidade de transformação do pensamento. Para uma equiparação das forças, acreditamos ser preciso acrescer da energia que for suficiente, o conteúdo ideológico que fundamenta tanto a festa popular subalterna quanto as manifestações que lhe são próprias. Através deste conteúdo, reconhecer o que for próprio das subjetividades das relações humanas. Próprio significa independer de comandos. Depender sim das vontades e da soma das vontades - hegemonia. Comprovadamente, como quando o festeiro se obriga a respeitar o que foi aprovado pelo povo por aquiescência não por imposição. ${ }^{267}$ Muito menos se trata de homogeneizar as vontades, pois é exatamente a diferença de vontades que cria possibilidades. Podemos dizer a este ponto que, a festa popular subalterna é uma experiência bastante completa de auto-governo. Em um curto espaço de tempo, assimila e organiza a participação de um grande grupo de indivíduos. Por se repetir conforme datas e localidades, cria também uma estratégia de resistência em uma rede de comunicação por onde atuam e se revelam as manifestações mais espontânea quando o intuito é o da festa em si. Estamos dizendo que pequenas e grandes festas, como por exemplo, do interior paulista, persistem em seus modos, por que persiste ainda o intercambio das manifestações mais características. Assim como a recíproca é verdadeira. Muitas manifestações expressivas da cultura popular subalterna persistem, pois ainda reconhecem, nas festas populares, os seus espaços.

${ }^{267}$ Id., São Luiz do Paraitinga no dia 10/02/2009 


\section{3 - Inserção - Intervenção}

O que colocamos em questão neste ponto, é a metodologia de aproximação das iniciativas, sejam elas acadêmicas, da sociedade civil organizada e mesmo do poder público. Não é nosso objetivo tecer análises sobre a forma de atuação destas iniciativas. Porém, depois das problematizações neste trabalho desenvolvidas, são necessárias ao menos algumas considerações a respeito das expectativas em torno da temática. Se de um lado trabalhamos no sentido de dar ênfase ao que identificamos como o conteúdo ideológico que consubstancia a esfera das manifestações populares subalternas, por outro analisamos a metodologia na abordagem, quando ao se tratar da aproximação acadêmica e a atitude de aproximação quando ao se tratar do poder público ou de organizações civis:

Mas a estrutura da vida cotidiana, embora constitua indubitavelmente um terreno propício à alienação, não é de nenhum modo necessariamente alienada. Sublinhemos, mais uma vez, que as formas de pensamento e comportamento produzidas nessa estrutura podem perfeitamente deixar ao indivíduo uma margem de movimento e possibilidades de explicitação, permitindo-lhe - enquanto unidade consciente do humano-genério e do individual-particular - uma condensação 'prismática', por assim dizer, da experiência da cotidianidade, de tal modo que essa possa manifestar-se como essência unitária das formas heterogêneas de atividade próprias da cotidianidade e nelas objetivar-se. ${ }^{268}$

Também para o desenvolvimento desta sessão partimos de uma reflexão sobre as observações diretas de indivíduos atuantes nas manifestações, que neste trabalho auxiliaram-nos no tratamento com o objeto. Os valores monetários são, inexoravelmente, necessários para a realização do evento festivo, uma vez que dificilmente se escapa à lei da oferta e da procura.

Contudo, interessam neste ponto, algumas argumentações quanto à relação que se pode fazer entre a festa e o que podemos chamar de iniciativas externas, ou seja, das propostas de apoio, de fomento, de preservação e como já criticamos, de resgate. Entre as respostas colhidas nos trabalhos de campo

${ }^{268}$ HELLER, Op. cit., p.38 
destacamos que ao poder público cabe o controle sobre o tempo e sobre o espaço físico bem com a responsabilidade com a ordem pública. E, apoio financeiro, pois ninguém trabalha sozinho. ${ }^{269}$ Entendemos haver a necessidade de um tratamento mais aprofundado a esta questão de apoio financeiro, primeiro quanto ao destino do que se arrecada da festa; segundo, quanto à formação de um fundo básico para cada evento, em se tratando especialmente das festas populares subalternas, não, porém para os eventos que já foram cooptados pelo sistema mercadológico. Tratamos enfim de eventos públicos; estes eventos em grande parte, ainda ocupam as ruas e muitas vezes toda a cidade onde se realizam. Também foi possível perceber que, esperar por ajuda não faz parte dos princípios básicos da formação das manifestações. A questão se resolve então, com transporte e alimentação dos quais não se pode prescindir. $^{270}$

Um mergulho é a real possibilidade de inserção neste caso. O homem já passou pelo processo de edificação das sociedades. Uma vez que já deliberamos sobre a necessidade do outro para a defesa e manutenção da vida, mergulho é essencialmente necessário para a compreensão dos instantes de subjetivação. Isto quer dizer que, o que se refere ao sujeito somente se efetiva objetivamente através do outro. Quanto a esta afirmação não há necessidade de maiores aprofundamentos aqui. Interessa é reverter o esquema de individuação dos interesses, na medida dos recursos, das novas reflexões e ações neste sentido, convergentes. Este esquema coloca, em certo ponto de vista, ricos contra ricos na guerra pelo poder; ricos contra pobres pela manutenção da ideologia do poder; de outro ponto, pobres contra ricos pela manutenção da resistência, e na pior das perspectivas pobres contra pobres. Por sobrevivência, ou pela satisfação ilusória da posse dos bens de consumo massivo, vê-se nesta espécie de distorção no interior da ideologia subalterna, a vulnerabilidade ao esquema de dominação. Ainda que alijados do que entendemos ser a verdadeira propriedade, "os pobres podem servir como representantes ou, melhor ainda, como expressão comum de toda a atividade

\footnotetext{
${ }^{269}$ Entrevista concedida a este pesquisador em São Luiz do Paraitinga em 10/02/2009

${ }^{270}$ Id., São Luiz do Paraitinga no dia 09/02/2009
} 
social criativa."271 Medir apenas esta atividade, de fora, não pode conduzir a qualquer modalidade de transformação, sendo que este ato criativo se explicita na socialização. Neste ambiente, a própria restrição de recursos consensualmente amplia as possibilidades e alternativas aos outros, como na readequação de mecanismos e materiais. Podemos considerar em contra posição que, toda a tecnologia aplicada à reduplicação das formas, não condiz com esta organicidade criativa. Portanto à dimensão subalternidade faculta-se a autocriação/recriação de seu ambiente. Aos ricos e dominantes à cópia.

A intervenção sendo um contra-senso parte quase sempre do princípio de existência do problema e a quem afeta. Para ser resolvido mobiliza-se, conforme as teorias mais eloqüentes, quem estaria mais bem equipado para tanto. A concepção de um interregno entre as classes subalternas, de massa sem comando, justifica esta postura. A política de preservação, por exemplo, cria também um quadro esquemático de ordenação de como as coisas devem ser apreciadas. Um dispositivo de articulação das coletividades, menos da identidade nacional cultural, nos moldes da intervenção. É importante frisar que quando se dá este processo, o interventor procura o centro para conduzir as tomadas de decisões e medidas. Portanto, tornam-se inaceitáveis atitudes como estas projetadas às formas coletivas e autênticas de expressão. Por isso salientamos que, mais do que encontrar formas adequadas de preservação ou de manutenção da cultura, é necessário se estudar as possibilidades de reestruturação dos sensos de propriedade e de reciprocidade do homem com os ambientes próprios para sua socialização.

É importante destacar na questão, não somente a relação entre ricos e pobres, dominantes e dominados, mas o que se indaga a respeito de qual seja o lugar dos intelectuais e das outras formas de interesse. Se este lugar é o da indiferença e, portanto toma-se a distância apropriada deste ambiente com objetivo de melhor descrever o fenômeno; ou, de inserção experimentando no cotidiano as vicissitudes - os momentos criativos da massa.

Para uma apreciação destas reflexões segue a apresentação de experiências que a nosso ver uniram e mobilizaram esforços de diversos segmentos da

${ }^{271}$ HARDT, Michael; NEGRI, Op. cit., p. 180 
sociedade. Ocorridas entre 2004 e 2008, as iniciativas realizaram-se na ocasião da Festa de Nossa Senhora do Rosário, como também em uma ocasião de cunho não religioso, no município de São Luiz do Paraitinga no Estado de São Paulo. É importante ressaltar que estas experiências se efetivaram em momentos de festa, porém, não sem uma filosofia.

Em outubro de 2004, realizou-se em São Luiz do Paraitinga um programa de estudo sobre História e Culturas Africanas no Brasil. A propósito de que quando queremos divisar algo que está ao longe, procuramos elevar nosso ponto de vista e, instintivamente postamos uma das mãos acima dos olhos, diminuindo a luz que ofusca a visão e, no jogo da perspectiva, o que queremos enxergar fica sob a nossa mão em concha.

No Brasil e na América Latina permanecem questionamentos a respeito de identidade, etnicidade e mesmo de autenticidade cultural baseada em modos ancestrais. Estes questionamentos têm reflexos evidentes em setores como a economia, a política, a formação dos cidadãos e atualmente corresponde ao nível de "risco" na esfera da geoeconomia. Apesar da forte pressão imprimida pela velocidade com que se difundem as informações, e do quanto se impõem os estereótipos mais gerais, estas respectivas nações têm buscado em suas raízes étnicas a força, chamada hoje de "identitária" (mesmo quando se trata de imigrantes), para resistir aos refluxos de uma corrente atual que suga as estruturas nacionais para o buraco negro do mercado mundial. Buscam ali também impulsos para reagir e lutar contra um processo global de exclusão. Sabemos que muitos são os que não têm acesso à informação, à formação e de maneira crescente ao alimento e à água. Não nos resta dúvida de que estamos voltando para nosso senso de pertencimento, com uma leitura mais atenta destas raízes. Tentamos, enquanto povo, construir e reconstruir uma ética de comunidade.

Porém, não fazemos tal leitura senão quando voltamos nossos olhares para o vasto horizonte das singularidades humanas de cada país, um olhar para dentro da cultura de fundo mais ancestral de cada grupo. Podemos observar efeitos desta leitura quando evidenciamos, por exemplo, o quanto se tem 
descoberto de recursos naturais para as ciências médicas a partir de conhecimentos da chamada "medicina popular", ou "medicina da floresta". No que se refere às manifestações expressivas, a capoeira transformada em disciplina em universidades mesmo de outros países. São certamente indicativos das propriedades deste campo.

Sem desmerecer as outras nações da América Latina, temos que dar destaque ao Brasil pela diversidade cultural, devido à distribuição territorial de diferentes "cruzamentos" étnicos, gerando interpretações distintas do mundo. Devemos salientar que apenas começamos a dar os primeiros passos na compreensão de quem somos.

Assimilamos infantilmente as influências culturais norte-americanas e as etiquetas educacionais da Europa. Desfizemo-nos de nossas raízes lingüísticas e quando olhamos para a cultura própria, a vimos, já como (um bom) produto. Ainda não conseguimos dar conta do homem brasileiro na sua totalidade e, portanto, ainda não conseguimos salvar este homem de misérias sociais. Apesar de muito ter se perdido, temos a nosso favor, além desta diversidade, o fator juventude da nação. Com respeito ainda a este olhar para as raízes culturais, de modo mais freqüente e em certos casos mais profundamente, encontramos estudos descritivos à maneira de registro histórico como também encontramos iniciativas que espetacularizam as formas em expressões do "nosso folclore"; contudo, estas expressões nunca deixam de estar carregadas dos sentidos éticos e ideológicos das relações humanas, próprias das circunstâncias de formação daquele povo ou nação. Em outras palavras, os elementos que compõem o universo simbólico das festas populares ou de um elemento expressivo dentro delas, têm completa correspondência com a história vivida e o cotidiano daquele povo. Por isso mesmo, somos o que somos, fazemos como fazemos por que descendemos e aprendemos com o passado. São as ascendências étnicas, dentro um processo dinâmico de "encontros e aproximações" entre diferentes etnias, que continua a comunicar modos de ser e fazer através da língua e dos hábitos. Dentro de nossa porção cultural africana, poderíamos, enquanto brasileiros, considerar que, num primeiro momento, recebemos daquele continente, ainda que por imposição, 
violência e ultraje, a força para o trabalho, para lutar e, uma resistência moral instalada na crença que se traduz em modos de expressão, com fundamentos comuns, mas ressignificados, conforme o contexto ${ }^{272}$.

Contingentes humanos de ancestralidades distintas, distribuídas em porções por territórios americanos que, durante séculos, mediante uma ordem socioeconômica que dividiu a humanidade em classes, gritam dentro de "nós" ao som das Companhias de Moçambique, do Jongo e das Congadas. Daquele primeiro momento, e ao longo da história de nosso país, temos só vivenciado a majoritária influência da cultura africana em vários aspectos das atividades humanas neste continente. De lá para cá, este processo dinâmico e contínuo de encontro e aproximação tem se revelado em uma observação e iniciativas mais contundentes [como é o caso da Lei 10.639/03]. A cada vez que se intensificar o foco sobre os modos de ser e fazer próprios das diversas regiões da América Latina, em especial neste caso, do Brasil, haveremos sempre de constatar um sentido de unidade em termos de cada nação. Porém, importa bem mais, a complementação do indivíduo, a configuração dos sujeitos, o autovalor em um processo de (re)-humanização da sociedade.

Estas porções para o Brasil são relevantes, uma vez que não se trata simplesmente de miscigenação (como resultado de migração, por exemplo), mas da própria formação do povo. Formação no sentido mais profundo que se puder adotar, pois, tendo sido a nossa infância como nação, modelada como réplica de uma cultura "importada" e imposta, a maturidade deve ser crítica.

Ainda não tivemos tempo suficiente para aprender sobre o que se tem por formado. Apenas começamos a penetrar no esboço de conhecimentos e tecnologias oriundos destes encontros, mas já estamos bastante avançados quando falamos das fragilidades sociais (violência, drogas, prostituição infantil etc.). Por isso, se considerarmos o aspecto cognoscitivo da dimensão das nossas subjetividades, é possível que encontremos muito mais que atração para os turistas e fomento para o comércio. São certamente outros os sensos de sustentabilidade, encontrados em culturas mais arcaicas e suas

${ }^{272}$ FERREIRA, Op. cit., p. 31 
ascendências diretas. Como no caso da relação extrativa com a floresta de seringueiros e castanheiros, que mantêm práticas na forma de tradição que preservam o ambiente em oposição absoluta ao avanço das monoculturas e das áreas de pastagem dos grandes latifúndios.

Em muitos momentos, nestas práticas, o próprio trabalho (coletivo, pois tem poder de igualar, transfere-se, socializa e une) é o momento da festa. No jogo injusto das forças contra os monopólios capitalistas muitas destas práticas, são simplesmente suprimidas; o homem é completamente separado de seu meio de trabalho e ele próprio é reduzido à mão-de-obra. Mas, quando se torna possível divulgar dados promissores da economia com base na participação destacável da "agricultura familiar", como se tem constatado em muitas regiões do país, não podemos deixar de lado o fato de que o Brasil ainda se encontra com um forte vínculo com suas raízes rurais, dadas as características estruturais de formação histórica do povo. A disponibilidade de terras aráveis e florestas (que ainda podem ser salvas e recuperadas) e a identificação com uma cultura popular como reflexo do cotidiano rural pode significar alternativas para a consolidação de uma base estrutural de sociedade orientada por valores mais humanísticos.

Sabemos que o universo das manifestações culturais populares no Brasil, que tem como uma das matrizes a África é imensamente vasto e diversificado. Em grande parte, estas manifestações traduzem-se em momentos de concentração de pessoas em torno de inúmeras possibilidades de celebrar, religiosamente ou não. Traduzem-se em momentos de festa. Fazem com que analisemos, por um lado, as festas populares como eventos de convergência, na maioria das vezes, oportunidades de consumo massificado e condicionado para pequenas multidões móveis e específicas (como é o caso das festas country, festas rave etc.). Tais eventos chegam a mobilizar, de forma voluntária ou involuntária, toda uma cidade ou toda uma região (como as festas juninas no Nordeste e do boi no Amazonas), e são vistos como ambiente propício para grande mercado. Muitas vezes fica difícil distinguir o que não foi transformado em produto. Entretanto, é necessário ressaltar que, diante de um olhar investigativo sobre o que está preservado e sobre o que se revela quando se 
demove a poeira do esquecimento, apresentam-se significativas retomadas do uso de muitas daquelas práticas, como são os casos em que capoeira, Moçambique, Lundu, Jongo, Congada, Maracatu etc., vão para dentro de escolas ou ampliam a abrangência de projetos sociais. Simplesmente porque estas grandezas simbólicas, contidas nas manifestações espontâneas são mantidas no histórico de muitas comunidades, que ainda preservam seus elos de coesão, são uma vontade potencial. Grandezas estas que são colocadas em prática apenas com a participação de indivíduos, seus instrumentos e acessórios artesanais. Assim, propor o desenvolvimento de estudos no ambiente da Festa do Rosário trouxe como inovadora a possibilidade ideológica de se escapar àquela ordem de mercantilização de todas as coisas, inclusive da festa popular.

Não se trata de introduzir práticas acadêmicas no ambiente de festas, nem torná-las tradicionais. Porém, como evento de convergência e como momento onde culminam pulsões de desejos em realizações sociais cíclicas (como, por exemplo, a Festa do Divino, cuja tradição é dar ao Divino em agradecimento e por uma nova safra), acreditamos poder apreciar na Festa do Rosário o ponto de partida para a identificação de modos comportamentais, com raízes étnicas africanas e que esta identificação possa representar alternativas para o que estamos vivendo hoje (exclusão e degradação do ambiente e desagregação social). Acreditamos que nos instantes de festa, o estudo possa ser tão lúdico quanto uma procissão ou os guizos e batuques. Não é necessária a distinção por disciplina ou o tipo de manifestação cultural observada isoladamente; interessa sim, a atmosfera de coisas se fazendo no espaço/tempo da festa como tal. Além de um momento, ápice de um processo, muitas vezes cíclico, a festa é também a vivência criativa. A seguir o que foi experimentado, precisa ser difundido e apreciado como valor (de uso), não de mercadoria. Com persistência, de dentro deste laboratório possivelmente replicaremos práticas significativas para o desenvolvimento da sociedade humana.

A própria festa se apresenta como veículo de difusão. Sua replicabilidade se revela tanto na diversidade de temas conforme as regiões, como na quantidade de datas festivas tradicionais do Brasil. Consideremos ainda que cada 
localidade traduziu, à sua maneira, as influências formativas do cotidiano. Uma luz sobre o universo das atividades, ferramentas, noções de economia, política, ética, solidariedade, estética. Tudo aquilo que se pode destacar com respeito à influência da cultura africana deve ser respeitado aqui, como elementar quando tocamos a porção maior do povo brasileiro. De quando falamos, comemos, trabalhamos, festejamos e construímos, pode-se destacar sempre alguma coisa trazida daquele continente que continua latente, tanto aqui quanto lá. Poderíamos conjeturar que o processo de comunicação das influências continua (principalmente quando falamos de trabalho, comida e música), agora amistosamente. Este é um processo dinâmico que pode ser alimentado ao ponto do intercâmbio cultural mais direto para que a aprendizagem, e principalmente o reconhecimento de nossa ancestralidade, se permita à complementação.

Em muitas cidades do Brasil se celebra a Nossa Senhora do Rosário dos Homens Pretos, em destaque aquelas cujos negros puderam erguer uma igreja. Em São Luiz do Paraitinga, cidade reconhecida pelas festas, pelo carnaval, pela Festa do Divino, e agora pela Festa do Saci e pela Semana da Canção Brasileira, por ser a cidade natal de Oswaldo Cruz, Elpídio dos Santos e Azis Ab'Saber; por ser uma cidade construída em boa parte por mão-de-obra escrava, por ainda preservar grande parte da população em zona rural e porções nativas de Mata Atlântica, configura-se um ambiente bastante oportuno, para o desenvolvimento deste tipo de atividade. E, por se intensificarem nos últimos anos, sob orientação de diversas disciplinas, as visitas e a permanência de estudante e pesquisadores a cidade também desenvolveu seu potencial receptivo.

Se projetarmos esta iniciativa para uma situação tribal, poderíamos imaginar um momento a cada ano em que os anciãos falam aos mais jovens antes de comemorar uma colheita ou outra vitória. Certamente este conselho é algo que, com o processo de individualização do ser humano, mesmo e principalmente nos núcleos familiares, se tem perdido, pois são outros os valores éticos e morais, como se destacar, por exemplo, o uso da força física para os jovens. 
Considerando-se o grau de replicabilidade do programa projetado à extensão do território nacional, é interessante que se procure garantir os aspectos correspondentes às dimensões do político e do ideológico, para a organização da sociedade e dos princípios pedagógicos cujos objetivos são a síntese e a continuidade do processo histórico de formação. Dentro da iniciativa, estas diretrizes estarão sempre acima da fomentação ao turismo (predatório) e da comercialização de bens culturais. Por isso mesmo, a festa deve se manter popular, feita pelo povo e nas ruas. É preciso reconhecer que muitas festas, dentre elas a Festa do Rosário carecem de fortalecimento e apoio. Neste sentido dois propósitos se casam: manter a festa e desenvolver conhecimento a partir dela.

Vivemos um instante já bastante adiantado do globalismo. Temos assistido a episódios, em muitos pontos do globo, que revelam muitas vezes reações, das mais variadas naturezas, mas que freqüentemente correspondem a questões de fundo étnico, como preconceito e discriminação e que têm como conseqüência violência e exclusão. Nações da América Latina, por terem passado por processos de colonização impositivos, e que, no entanto, foram projetadas aos reflexos destorcidos da modernidade da Europa, hoje lutam pela consolidação da democracia, não somente como regime, mas ampliada ao Estado. Nestas nações, onde alguns dos presidentes saíram de camadas mais pobres e desfavorecidas da população e que por isso expressam "valores culturais e identitários diferentes dos hegemônicos", como escreve Dennis de Oliveira ${ }^{273}$, podemos perceber uma forte tendência à valorização das "riquezas próprias", tanto das fontes materiais de recursos, quanto das subjetividades (considerando como subjetividades a esfera do saber científico ou popular). Nesta segunda fonte é onde podemos identificar o ser humano inteiro, intrínseco ${ }^{274}$. A festa como um espelho das atividades cotidianas de uma coletividade é também uma lente por onde podemos divisar fases do desenvolvimento humano onde muitas vezes se constataram momentos sócio-

\footnotetext{
${ }^{273}$ OLIVEIRA, Dennis. Por uma práxis jornalística alternativa. Jornal da USP - Publicação da Coordenadoria Social - Ano XXIV, no 846 de 29/09 a 05/10 de 2008. p. 13.

${ }^{274}$ HELLER, Op. cit., p. 27-34.
} 
econômicos menos díspares, de maior sociabilidade, pois uma festa é impossível com um único indivíduo, como já foi expresso.

Do ponto de vista sócio-econômico, quando pesquisamos as raízes dos eventos celebrativos encontramos freqüentemente o fenômeno da consagração de alimentos a divindades especiais, como forma de garantia da proteção e de novas safras. Em alguns casos, parte da colheita era dada como oferenda, em agradecimento. Um exemplo notório desta postura é o fato de que as Companhias de Congadas e de Moçambiques não admitirem o cachê artístico. Esta forma de oferenda, ainda em prática hoje em dia (o afogado, na Festa do Divino), que é distribuída gratuitamente entre a população corresponde (e só é possível a partir de) a um excedente da produção e por este aspecto pode corresponder também a uma espécie de "prestação de conta", Não exatamente um balanço monetário, mas, muito mais um demonstrativo do potencial da terra e do trabalho, e das totalidades humanas (capacidades, necessidades, ciência, prazeres, forças e habilidades).

A contradição está obviamente na distribuição gratuita de um excedente que hoje não escapa à produção de renda, mas pode ser analisada como senso de uma economia que tende a reverter o conceito de propriedade; de privada para o de relação de apropriação, mais concernente às relações humanas do que tão somente a acúmulo de capital. A vida não pode continuar se resumindo em produção e consumo. Devemos sobrepor esta dependência, como vícios de comportamento e experimentar a liberdade.

Se algo está sendo festejado, não poderá ser por um saldo negativo. Para que se efetive esta positividade, é preciso que se recarregue de sentido simbólico o ciclo de determinadas festas brasileiras que, destituídas de suas características fundamentais, tiveram estilizada sua aparência circulando como imagem/informação. No caso específico das iniciativas realizadas a Festa do Rosário dos Homens Pretos é a nossa lente. É através dela que se pretende contribuir para que a história e a cultura africana se perpetuem nas raízes históricas do Brasil como conhecimento e cultura. 
Outro evento que além do caráter festivo, também se transformou em ambiente de observação da realidade circunstante foi o Io Seminário sobre Cultura Caipira: História e Perspectiva Atuais - O Papel da escola e da Comunidade, realizado na cidade de São Luiz do Paraitinga nos dias 21 e 28 de julho de 2007 complementando a festa de aniversário da SOSACI (Sociedade dos Observadores de Saci).

Em outubro de 2008, na mesma cidade, uma nova experiência sobre História e Culturas Africanas no Brasil se realizou desta vez com oficinas de Capoeira Angola, Palestra com Pedro Moraes Trindade ${ }^{275}$ e a presença da Companhia de Congada da Fonte Imaculada e a Companhia de Moçambique Mirim do Bairro dos Alvarenga.

A partir destas apresentações, devemos esclarecer que não estão em questão, nem verificar a participação das diversas iniciativas, nem dimensionar a funcionalidade de suas ações mediante algum problema previamente observado. Importa, antes de qualquer coisa, considerar, no que corresponde à ideologia das classes subalternas através das festas, o que nesta, existe com sentido de universalidade. Não somente no que se refere à diversidade quanto ao que se pode propor, mas pelo seu sistema próprio de comunicação em massa. Se acatarmos a proposição de valor gnoseológico atribuído ás manifestações singulares da cultura, podemos perguntar se não se revelam neste contexto também as possibilidades de relações pedagógicas. Haverá momentos mais frutíferos para as relações de ensino e aprendizagem do que nas experiências espontâneas e livres? Perguntamos também: poderíamos inserir entre estes, os momentos lúdicos da festa popular subalterna?

Se não estamos tratando exatamente de um dispositivo da articulação - um contra-discurso - à ideologia dominante ao menos poderemos considerar uma porta de acesso a ele. Se assim o temos, lançamos o alerta para o processo ou de dissolução deste espaço quando se enfraquece a vontade popular, ou quando, com os fetiches da maquiagem liberal cresce - gerando lucro.

\footnotetext{
${ }^{275}$ Pedro Moraes Trindade é Mestre de Capoeira Angola em Salvador - Bahia. Autor da Tese Do Lado de Cá da Kalunga: os africanos angolas em Salvador 1800-1864 -UFBA Universidade Federal da Bahia data de entrega 15 de setembro de 2008
} 
Portanto a inserção diz respeito ao sujeito que se integra pela própria ação - é subjetiva; o objeto desta atitude são também as subjetividades das relações materiais humanas. Defrontamos-nos, obedecendo à metodologia com uma intersecção dialética entre sujeito/objeto. Neste momento o pesquisador, por exemplo, transporta-se para condição de objeto da problemática como um todo. Metodologicamente, a problemática controla a distância precisa para a perspectiva que se quer tomar. Permite até certo afastamento para as confabulações. Porém sem o que consideramos ser a inserção, todo empenho nas observações poderá vir a não passar de um aporte teórico.

Como na intervenção ou interferência, os objetivos mais distintos e difusos dos sentidos iniciais da festa bem como das manifestações espontâneas que nasceram em função dela. Em função de alguma forma de vantagem, não há sequer aproximação, pois precisam ser resguardados os respectivos espaços disciplinares e seus respectivos gabinetes. 
This document was created with Win2PDF available at http://www.win2pdf.com.

The unregistered version of Win2PDF is for evaluation or non-commercial use only.

This page will not be added after purchasing Win2PDF. 


\section{CAPÍTULO 4}

\section{CASQUETES, PAIÁS, FITAS, BASTÕES, ANGUÁIAS E TAMBUS.}

\subsection{Equipamentos Simbólicos}

Uma ocasião de festa não é nunca um momento comum. Apesar de se inserir no cotidiano é sempre uma ocasião em que, auspiciosamente, muitos preparativos são feitos. De um lado, com já apresentamos, pelos que realizam a festa, de outro, os que vão para o evento, levando suas perspectivas e promessas. Há dentre estas atitudes, aquelas que simplesmente se resumem em se fazer presente na ocasião. Outras que se traduzem nas intenções religiosas. Porém, existe uma forma de participação, que passou a ser imprescindível, que correspondente a própria realização da festa. Não quer dizer que uma festa não possa ser feita sem este componente, mas que neste caso um vazio reclamará a falta. Trata-se das manifestações expressivas. Queremos com esta propositura, destacar neste ponto, algumas reflexões sobre como se preparam os dançadores para estas ocasiões. Sabemos que há uma preparação do espírito, ou seja, é quase impossível que entre os acessórios e as paramentações não estejam impressas na consciência a memória saudável deste momento de alegria. 
Inicialmente, devemos distinguir estes acessórios. Os nomes que acima foram usados para dar título ao capítulo, referem-se a objetos usados como acessórios na Dança do Moçambique e no Jongo. No Moçambique, os Casquetes são uma espécie de boina de tecido bordado complementando o uniforme. Os Paiás são pares de chocalhos feitos a princípio com latas e sementes ou cacos de conchas, amarrados abaixo dos joelhos dos dançadores, posteriormente passaram a ser usados pares de guizos que dão um chiado bastante característico do gênero, acentuando o ritmo. As Fitas adornam os uniformes e as bandeiras, servem inclusive para diferenciar os pares na contradança. Os Bastões de madeira (guatambu) são manejados e percutidos durante as danças em diferentes coreografias. No Jongo a Anguáia e os tambus são instrumentos rítmicos que ajudam na cantoria. ${ }^{276}$

Não são somente estes os materiais usados, nem foram aqui escolhidos como principais. Além da intitulação, pensamos em introduzir através destes, as reflexões sobre a carga simbólica que possam ou não trazer quando associados à expressão de uma linguagem e sua reciprocidade com a atividade cotidiana. Antes, porém, é importante que se esclareça que em boa parte as reflexões são amparadas nas contribuições dadas a este trabalho de pesquisa, na sua fase de campo, por pessoas têm completa ligação com as formas de manifestação que servem ao nosso foco. ${ }^{277}$ É importante ressalvar que, tratando-se de metodologia com fim não-quantitativo procuramos nos concentrar em pontos de congruências e de conflitos, com objetivo de identificar possíveis desvios e possíveis convergências com respeito ao político-econômico-filosófico das festas aos quais daremos destaque.

Se o capitalismo atribui preço ao valor, o neoliberalismo movimenta o mundo a partir do consenso sobre a possibilidade de lucro monetário nas coisas. Estas mentalidades quando colocam em sistema de disputa 0 safar-se individualmente pela posse, pelo acumulo de valores e pela concorrência, permitem postular que a maneira de subvertê-las diametralmente deve ser

\footnotetext{
${ }^{276}$ Entrevista concedida a este pesquisador em Lagoinha no dia 13/02/2009

277 Entrevistas concedidas a este pesquisador nas cidades de São Luiz do Paraitinga e Lagoinha entre os dias 09 e 14 de fev. de 2009
} 
encontrada quando se compreende o que se apresenta em fundamental contradição a elas, ou seja, em valores comuns que não tem preço.

A globalização (neo)-liberal envolve e dá acesso a tudo pela égide da ocidentalização do mundo. Globaliza o que é da esfera do objetivo e do subjetivo; do que é objeto das transformações e do que é da consciência humana. Ao pretendermos trabalhar o valor atribuído a uma manifestação ou sistema de manifestações culturais, chamamos a atenção para o que, dentro deste sistema ainda não traz preço impresso; o acesso a isto pode ter, mas possui em si um escudo ao preço que é seu próprio valor enquanto subjetividade, enquanto equipamento simbólico dentro das relações de trabalho (a atividade humana). Está intrínseco nestas relações; não é um hiato compensatório do labor. É em si o próprio trabalho cujo núcleo complementase de objetividade e subjetividades. Falamos de atividades que estão em completa função com a socialização. Portanto, seu valor somente se efetiva ou evidencia quando em relação ao outro. Valor histórico ou valor de informação sequer se aproximam do valor do símbolo. O problema consiste em que o simbólico ao ser revelado pela ciência ou pelo afã liberal passa a pertencer à ordem daqueles valores. A princípio, a descoberta parece circular tematicamente pelas salas de estudos, gerando nova série de conceitos, como acontece ultimamente com o tema identidade, em seguida passa ao esquema de distribuição do acesso - globalização. Argumentamos que esta metodologia é correspondente a um pensamento de ocidentalização do mundo; utopia de socializar o mundo através da circulação da informação. Todos estão sabendo. Contudo essa acessibilidade não se traduz em auto-reprodução enquanto se resume em uma via de mão única da produção ao consumo. Deixa-se, contudo de considerar o quanto aquele valor simbólico já representara sobre o fator socialização. Observamos que se diluem os ambientes e as oportunidades vão se dissolvendo conforme o interesse mais premente. Podemos, a este ponto, citar o que nas entrevistas se apresentaram como dificuldades. Dentre elas, a mais freqüente é a questão do transporte. ${ }^{278}$ É interessante pensar que como dificuldade, esta questão sempre existiu. No entanto é mais sentida, atualmente, quando existem em maior quantidade, veículos motorizados. No

${ }^{278}$ Id., São Luiz do Paraitinga e Lagoinha entre os dias 09 e 14 de fev. de 2009 
período dos bairros rurais ia se a pé ou a cavalo (dificuldades naturais). Não há crítica ao progresso, mas ao fato de que esta quantidade tem direcionamentos que na escala das prioridades não contemplam ou contemplam menos os deslocamentos dos que expressão sua cultura. ${ }^{279} \mathrm{O}$ custo de uma viagem se interpõe entre a espontaneidade e o ambiente de explicitação. Decorre desta interposição outra dificuldade que diz respeito à participação na festa. Ao contrário do convite para animar o leilão na festa, o Moçambique é chamado para uma exibição com tempo contado competindo pelo espaço com os sistemas de reprodução eletrônicos de som. ${ }^{280}$

Outra dificuldade apontada está em se arrumar parceria e reunir as pessoas. ${ }^{281}$ A este respeito consideramos primeiramente toda a transformação física do próprio lugar. Entretanto levamos em conta a marginalização daquelas formas de saber; o pré-conceito ao se defrontar com os enxertos da modernização - a tecnologia é outra. Quando concebida no limite das manifestações espontâneas pode parecer uma abordagem simplista, mas se ampliamos para o circuito da formação do indivíduo, podemos questionar se toda divulgação seja ela dos modos antigos de expressão (riqueza cultural) como os mais modernos têm da mesma forma, ampla capacidade de formar sujeitos. Não deixa, contudo de preparar especialistas e técnicos, que de uma maneira ou de outra são, eventualmente absorvidos pelo mercado. Também não deixa de formar público/consumidor, mas não se apresenta tão eficiente na formação da afetividade, no vinculo sensório-emocional da sociedade. Nas entrevistas concluiu-se por um padrão diferente da tradição antiga. ${ }^{282} \mathrm{~A}$ partir desta observação pode se admitir que por padrão compreende-se um conjunto de procedimentos que não se reduz às partes. Não se trata de um problema desta ou daquela área ou setor que deva se tratado pontualmente - como na maioria das vezes são as propostas de preservação. Trata-se do problema em torno da consideração aos valores morais sendo que estes participam fundamentalmente na compleição física e por que não, metafísica do sujeito. Compreender e transformar o mundo não dependerá das somas, das quantias investidas, mas do quanto ainda se poderá restituir ao elemento humano sua

\footnotetext{
${ }^{279}$ Entrevista concedida a este pesquisador em São Luiz do Paraitinga no dia 14/02/2009

${ }^{280}$ Entrevista concedida a este pesquisador na cidade de Lagoinha no dia 13/02/2009

${ }^{281}$ Entrevista concedida a este pesquisador na cidade de São Luiz do Paraitinga no dia 14/02/2009

${ }^{282}$ Id., São Luiz do Paraitinga no dia 14/02/2009
} 
relação de auto-reprodução em ambiente que lhe seja próprio. Merece destaque a contradição que se pode observar que neste processo onde não se formam novos sujeitos plenos, consiste no fato de que primeiro na pósmodernidade a cultura é colocada como algo ao qual o indivíduo poderá escolher fazer parte ou não. Depois de feita a escolha terá de concorrer a ela. Difere do conceito de cultura tomada ao ambiente de sua propriedade.

Ao reclamarmos maior ênfase para o valor simbólico destes equipamentos, diretamente reivindicamos o reconhecimento dos sensos de propriedade e de reciprocidade na base de formulação da ideologia que sustenta o saber. Esta base deve compreender e relacionar tanto a atividade dos que praticam quanto dos que pensam e concebem teorias sobre a atividade no movimento nãouniforme da dimensão subalterna da sociedade.

\section{O Valor de uso e o valor de troca dos equipamentos simbólicos,} correspondem ao que identificamos, nas respostas colhidas ${ }^{283}$, como atributo dos acessórios (dos aparelhos, como são comumente chamados), por exemplo, a capacidade de concentrar por um lado referência direta ao uso, ou seja, valer como instrumentos para ajudar na cantoria, como embelezamento elemento atrativo da festa, como autenticador da diversidade na expressão dos modos culturais. No conjunto estas condutas também se vinculam a valores de troca; uma vez quando há compensação pela atenção ao trabalho, ou seja, quando se leva em conta que a festa é o ambiente primordial de explicitação daquelas formas, neste caso não circulam valores monetários diretamente, tampouco se obedece algum tabelamento prévio; outras vezes, quando a sua função se estabelece em atrair público para finalidades meramente lucrativas ou então de vender uma imagem de riqueza cultural nacional a despeito da marginalidade social onde se desenvolvem.

De outro lado, há uma carga de cognitividade quando fitas de diferentes cores são usadas caracterizando grupos que se interpelam em confronto lúdico nas performances de uma dança. Sem este confronto não há desenvolvimento do bailado ou dos manejos (percussão dos bastões no Moçambique). No Jongo este confronto se dá na própria roda onde ao movimento frontal com outro participante, muda-se a direção para outro movimento frontal com outro

\footnotetext{
${ }^{283}$ Entrevistas concedidas a este pesquisador nas cidades de São Luiz do Paraitinga e Lagoinha entre os
} dias 09 e 14 de fev. de 2009 
participante, também há um confronto lúdico e direto entre os participantes que apresentam os pontos. ${ }^{284} \mathrm{~A}$ anguáia (espécie de chocalho feito da trama com lascas de bambu e contas) atribui ao jongueiro oportunidade de cantar seu verso, mas não antes do verso corrente completar três voltas. ${ }^{285}$ Corresponde igualmente a esta carga de cognitividade o quanto corrobora com uma cadeia de sentidos onde uma expressão abre margem de existência à outra expressão. São as manifestações espontâneas que carregam de sentido o ambiente da festa que é ao mesmo tempo é a garantia de oportunidade para experiência lúdica. Atribuímos a estes equipamentos simbólicos as dimensões na relação de propriedade considerando que no momento inicial da formação daqueles modos expressivos, boa parte dos elementos foi colhida entre as formas preservadas da cultura ancestral e outras partes colhidas no cotidiano. Os tambús ${ }^{286}$ (tambores feitos em tronco roliço com a parte interna escavada e, com uma das extremidades revestida de couro) no Jongo são um exemplo bastante significativo desta forma de comunicação com o passado. O espaço do terreiro, fogueira e toda subalternidade referem-se ao cotidiano da época.

Pretendemos afirmar com estas argumentações que aos equipamentos simbólicos consideramos como marcas materiais de sustentação de algum saber quando tem fim em si mesmo ou, de determinado saber quando há interesse científico. Porém, estes saberes não são invulneráveis ao fetichismo de mercadoria, e facilmente se transformam em algum tipo de produto da indústria cultural (imagens, turismo, informação enciclopédica instantânea etc.). Em nosso entendimento, é menos comum observar o que tem caráter de próprio tendente à troca pelo valor do bem de consumo, excetuando-se não quando o valor se dissolve nas relações de reciprocidade entre o homem e os objetos da sua atividade. Há certamente quem ultimamente sem condições de escapar a orientação mercadológica, não veja esse outro tipo de valor. Importa mais e acima de tudo que se leve em consideração que historicamente, ainda estamos diante destas explicitações, e que elas possam servir ao exame das possibilidades de se revelar a ideologia das classes subalternas através das festas.

\footnotetext{
${ }^{284}$ Entrevista concedida a este pesquisador na cidade de São Luiz do Paraitinga no dia 13/02/2009

${ }^{285}$ Id., São Luiz do Paraitinga no dia 13/02/2009

${ }^{286}$ Id., São Luiz do Paraitinga no dia 13/02/2009
} 
Sejam quais forem as estruturas simbólicas, aqui seus valores são considerados segundo sua capacidade de deslocar para outras vias de abordagem a relação com a cultura e em seu interior. Dois seriam os critérios para esta abordagem; o primeiro seria quanto à possibilidade de reconstituir o senso de propriedade inclusive na relação com a própria cultura, isto é, a consciência de que a cultura pode nascer do lugar onde se está e com o que se tem e, assim ser plena; isto não significa resistir às propostas externas, mas examiná-las mediante as próprias; se intervêm ou inserem-se. O segundo é quanto a possibilidade de elevação política de cada sujeito e de todos. Isto quer dizer que é antes, entre as subjetividades onde se pode examinar uma cultura do sujeito - ambiente e oportunidade. Por isso o sentido convergente à festa popular subalterna, por isso também as manifestações espontâneas e gratuitas que a complementam. Conforme as respostas às entrevistas o significado memorial humano para quem experimenta estes momentos se preenche com o merecimento, a diversão, o gosto, a união, devoção, ${ }^{287}$ a celebração do vínculo histórico com quem fez o mesmo muito tempo antes. Perguntamos se tais atitudes em conjunto não se referem às subjetividades e se não seriam projetáveis a outras esferas como a do trabalho ou da própria ordenação da sociedade. Não está se propondo que o trabalho e a sociedade se transformem numa grande festa, bastava que fossem humanizados. ${ }^{288}$ Tomemos das entrevistas o que o pertencer ou presenciar a uma explicitação da forma de manifestação cultural popular pode acrescentar à vida das pessoas. Destacamos primeiramente os deslocamentos, os encontros a convergência; em decorrência destes, a identificação. ${ }^{289}$ Uma forma de turismo menos calculista que culmina em uma espécie de interação sem tantas convenções. Excetuando-se o que é ritual na festa, todos que nela se encontram, expressam numa cultura própria que é sempre cabível. ${ }^{290}$ No processo de identificação qualquer manifestação de ancestralidade pode remeter o pensamento a um passado, à vida de um parente que daquela maneira se manifestava. ${ }^{291}$ Esta identificação também pode se refletir como

\footnotetext{
${ }^{287}$ Entrevista concedida a este pesquisador em São Luiz do Paraitinga no dia 14/02/2009

${ }^{288}$ Id., São Luiz do Paraitinga no dia 14/02/2009

${ }^{289}$ Id., São Luiz do Paraitinga no dia 14/02/2009

${ }^{290}$ Entrevista concedida a este pesquisador na cidade de Lagoinha no dia 13/02/2009

${ }^{291}$ Id., Lagoinha no dia 13/02/2009
} 
uma esperança individual de continuação daquela prática, o que em escala mais ampla se observa nos movimentos de preservação patrimonial da cultura. Acreditamos ser este elo que liga o sujeito á história, os pontos sensíveis que permeiam o tecido social cujo núcleo nunca pode fugir a humanidade do sujeito. Da parte de quem presencia o saudosismo, e a oportunidade de se interessar e se acrescer daquilo, uma ação impulsiona outra; da parte de que faz, quando maneja dá o seu derradeiro. ${ }^{292}$ Obedecendo ao espírito de convergência do qual o fenômeno festivo jamais dispõe, importa destacar o intuito de que mais gente saiba e participe; que se formem mais e novos sujeitos. No confronto lúdico do Jongo, hoje se planta; amanhã quem irá colher? ${ }^{293}$ Nesta concepção de legados, aponta-se, nestes casos mais especificamente a formação de novos mestres para o Moçambique e galos velhos para o Jongo ${ }^{294}$ - designação para as pessoas que respectivamente dominam a técnica. Em torno destes é que se concentram os que se interessam. Dominar a técnica, não corresponde somente ao aspecto funcional do indivíduo, mas a capacidade de concentrar conhecimentos históricos correlatos. Não somente, nos casos dos quais tratamos aqui, mas em toda extensão das atividades culturais próprias não será difícil divisar que se dilui a prática de formação do mestre. É importante ressaltar que diferente da academia esta patente se faz pela experiência, pela constância na prática e pelo fervor.

\footnotetext{
${ }^{292}$ Id., Lagoinha no dia 13/02/2009

${ }^{293}$ Entrevista concedida a este pesquisador em São Luiz do Paraitinga no dia 09/02/2009

${ }^{294}$ Id., São Luiz do Paraitinga no dia 09/02/2009
} 


\subsection{Subalternidade e Marginalidade}

A subalternidade refere-se ao sujeito, enquanto a marginalidade está relacionada à ideologia predominante, a marginalidade, portanto, é um imperativo. Subalternidade não é condição nem estado de coisa; é elemento essencial do núcleo básico da formação do socius. Aqui concebemos subalternidade como força que atua no movimento das coisas; não é servil ao ponto de ser condicionada, nem escravizada; marginalizá-la é o mesmo que coibir o fluxo vital da criatividade, da articulação, do esforço. Enquanto permanece o trabalho na condição de alienado, as manifestações subalternas populares também se desfacelam. O que significa marginalização? Significa que a liberdade, o senso de propriedade na relação com a cultura está sob o pre-domínio da ideologia vigente. Nesta lógica, não é difícil se admitir que o sujeito sofra uma espécie de apagamento, como fruto da tendência das intenções à mais-valia.

Os conceitos de subalternidade e marginalidade também são contraditórios quanto ao tempo. No primeiro caso conferem-se ao sujeito o instante e o tempo na sua totalidade; o segundo, operando no sentido do centro para o que está à margem, estabelece uma ordem de quem experimenta antes - colonização. Esta centralização da mesma forma predetermina o que deve e como deve ser valorizado de forma homogênea para que o mercado possa circunscrever seus nichos.

Assim para se alçar maior compreensão a respeito desta contraposição e mais, fazê-lo superando a ordem estabelecida, faz-se necessário que se amplie o campo de visão sobre as atividades humanas. Para a argumentação aqui desenvolvida, a ideologia das classes subalternas encontra se fundamentada filosoficamente no valor gnoseológico. Parte considerável da metodologia dialética. "É o estudo da origem, organização e validade do mundo das idéias, enquanto representação de coisas objetivamente reais." ${ }^{295}$ Para tanto, uma primeira ressalva é quanto a cientificidade que pode estar contida tanto em fenômenos simples quanto nos mais complexos. Mediante o pensamento moderno, os avanços privilegiam a complexidade principalmente no que se

${ }^{295}$ FERREIRA, Op. cit., p. 52 
refere à física, à mecânica. Privilégio que se amplia ao especialista daquela área. Não nos deteremos nessa análise. É necessário apenas que se diga que em função deste privilégio, muitas questões, principalmente, que dizem respeito às Ciências Sociais Humanas se distanciam na escalas das prioridades. Não é uma tarefa fácil argumentar sobre a importância do que se pressupõe como conteúdo ideológico nos fundamentos para a formação das expressões culturais subalternas. Assim sendo, enquanto não se consegue comprovar a pertinência destes pressupostos no embate de hegemonias que consubstancia o processo de ordenação da sociedade, permanecem e se avolumam na marginalidade uma parte significativa deste conteúdo. Combinado com esta marginalização, o processo de alienação do pensamento se incumbe de enxertar no pensamento outros padrões com valores flutuantes que identificação e descarte das aparências na velocidade co que as informações circulam.

Depois da discrepância no sentido unidirecional da marginalização, devemos a esta altura correlacionar subalternidade, marginalidade e comunicação. Devese considerar o quanto amplamente já se discutiu a respeito do sentido que a comunicação opera em cada esfera - mediadora de diálogo ou instrumento de massificação. Cabe então questionar, quando nos referimos às massas, a respeito do que se comunica e com qual finalidade, quais as respectivas proporções de forças objetivas no movimento de informar, de homogeneizar o pensamento ou orientar a reflexão para uma mudança de hegemonia. Neste sentido, distingue-se maior horizontalidade referente à comunicação entre as classes subalternas, enquanto às classes marginalizadas a verticalidade na exposição de preceitos.

Das respostas nas entrevistas realizadas ${ }^{296}$ destacam-se, com respeito à contradição acima descrita, em primeiro lugar a transformação dos bairros rurais em periferia quando entram em cena os serviços públicos e o acesso as tribulações urbanas. Quase inevitável, porém, observa-se predominante a marginalização principalmente na diluição do espaço (que não é rigorosamente físico, portanto não se trata de voltar para a roça) comunitário e de produção -

\footnotetext{
${ }^{296}$ Entrevistas concedidas a este pesquisador nas cidades de São Luiz do Paraitinga e Lagoinha entre os dias 09 e 14 de fev. de 2009
} 
onde nascem propriamente as manifestações culturais. Em parte o êxodo deve-se ao atrativo da cidade, mas principalmente às dificuldades encontradas no campo. ${ }^{297} \mathrm{O}$ confronto com grandes latifúndios e grandes produtores. $\mathrm{A}$ cidade torna-se um espaço de convergência, em função do fluxo de trabalho, da circulação de mercadoria e da procura de bem-estar. Os sujeitos são absorvidos neste fluxo. A praticidade do acesso a cultura/informação substitui os momentos de explicitação cultural próprios. Nos grandes eventos a aflição das massas por qualquer fração do que possa representar um desses momentos. Em seguida todos voltam à normalidade de uma espécie de busca constante pela satisfação ${ }^{298}$ dos anseios.

Em segundo lugar, a marginalização se intensifica na medida do confronto com os fetiches da mercadoria cultural moderna. Baixar e portar uma música no celular e colocá-la em execução parece causar mais satisfação que a experiência sensorial de uma dança. Em depoimento, ${ }^{299}$ muitos dançadores para se iniciarem em determinada forma de expressão alegam a orientação do avô ou do pai, a influência de um mestre o interesse próprio ao assistir em uma festa, pois esta, como já apresentado anteriormente, era também uma garantia da comunicação do passado com o presente. Assim a cada festa e a cada bairro a possibilidade de reprodução daquela forma. Não se pode deixar de acrescentar que atualmente a dissolução deste espaço corresponde a marginalização de formas expressivas culturalmente mais autênticas, e ao centro o que se apregoa como cultura de massa.

O método dialético permite observar a contradição entre subalterno e marginal onde marginalização impõe condição ao que é subalterno; a subalternidade subleva o marginal à qualidade imanente da força. Também pode-se admitir que a concepção de subalternidade refere-se a energia (massa), que no princípio de propulsão de qualquer movimento, é o próprio deslocamento; autorecria-se como cultura. Em outras palavras podemos dizer que todo trabalho desencadeia a mobilização de compreensões nas mais diversas linguagens, gerando outros trabalhos. Talvez, em se tratando das manifestações

\footnotetext{
${ }^{297}$ Id., São Luiz do Paraitinga e Lagoinha entre os dias 09 e 14 de fev. de 2009

298 BAUMAN, Op. cit., p. 117

${ }^{299}$ Id., São Luiz do Paraitinga e Lagoinha entre os dias 09 e 14 de fev. de 2009
} 
expressivas da cultura, mude sua nuance, mas é sempre trabalho. Por isso acreditamos na necessidade de aprofundamentos no exame da subjetividades das relações de trabalho. Trabalhar com cultura está longe da cultura do trabalho. Nesta o trabalho é movimento, se há movimento há força cujas correntes subjetivas da hegemonia se encarregam de repartir e redirecionar. Assistimos primeiro a atuação destas correntes sobre o trabalho propriamente, que atingiu seu auge com a industrialização. Agora atua sobre as subjetividades das relações de trabalho - o trabalho imaterial ${ }^{300}$ - as atitudes próprias do sujeito que não somente o identifica, mas o plenifica.

Subalternidade deve ser sempre observada à luz do pensamento de Gramsci (1966):

Poder-se-á indagar se a filosofia da práxis não é, precisa e especificamente, uma teoria da história; ao que responderemos que sim, mas que é impossível - por isso mesmo - destacar da história a política e a economia, mesmo em suas fases especializadas, de ciência e arte da política e de ciência e política econômica. Em outras palavras, após ter realizado, na parte filosófica geral - que é a filosofia da práxis propriamente dita: a ciência da dialética e a gnoseologia, na qual os conceitos gerais de história, de política, de economia, se relacionam em unidade orgânica. ${ }^{301}$

A subalternidade é em nosso ver esta unidade orgânica. É também o lugar da práxis, onde os recursos da ação, não esperam a tecnologia, mas a tecnologia pode nascer de experiências imediatas e comuns; a subalternidade é, portanto, o lugar onde as dissensões e as diferenças se transformam em força. Força material orgânica que na propulsão do movimento no sentido do que é o bem maior. Quer dizer que, como compensação dos esforços o bem maior corresponde à renovação da força que coloca o mundo em movimento constante. Não deve existir nesta concepção, o sentido de que alguém explore, quem se beneficie e se fortaleça em detrimento de algo que se degenere, se desvaneça e perca o valor. A utilização de mão-de-obra mediante uma contratação deve corresponder mais à troca de oportunidades. Nunca sem a

\footnotetext{
${ }^{300}$ HARDT; NEGRI, Op. cit., p. 149, passim

${ }^{301}$ GRAMSCI, Op. cit., p. 155
} 
respectiva compensação. Mas acima de tudo respeitando ao que cada indivíduo carrega consigo

Marginalidade é uma forma de dissensão, mas ao mesmo tempo corresponde a um movimento para fora. Não os referimos de forma especifica a uma saída, mas a um movimento de expansão inicialmente quando o centro impõe limitações e concorrência desleal, como melhores escolas para os filhos dos ricos; depois um movimento de contração, quando o centro necessita de consumidores dos produtos ordinários. A marginalidade também se refere à massificação ou não de produto da indústria da satisfação. Quando é deixada de lado a consideração a qualquer valor não monetário, a idéia de satisfação também se eleva a categoria de bem-estar. Poder gozar de momentos em que a satisfação é proposta de maneira homogênea, como em um cinema, tevês por assinatura ou games digitais, pode inclusive simular alguma idéia de controle; ou porque se adquiriu o acesso mediante sua compra, ou por ter as mãos o botão on-off.

O processo político que cria a subalternidade como condição é tendencioso e deve ser dissolvido, pois tem como prerrogativa justificar seu sistema de assistência, mas não há, como pudemos constatar ao longo desta reflexão, política sem filosofia. Sendo assim, na subalternidade, em meio ao seu turbilhão viceja o senso-comum, mas também é vigorosa a filosofia. Sem ela não se pode galgar sequer um degrau na compreensão do homem. Portanto, não há como edificar a ponte entre o homem-genérico e o conceito de universalidade (sem que isso pareça idealismo com resistência cultural), sem constar uma real consideração à política na composição da metodologia de qualquer reflexão sobre as Ciências Sociais. Sem esta porção, inclusive não há como se aproximar da dimensão subalternidade. Observada a filosofia política das massas torna-se possível que a subalternidade assimile em sua força, a força dos marginalizados que se reorganizam. No entanto não pode subsumir a marginalidade exatamente por corresponder à força e não fraqueza ou passividade. À subalternidade como um todo, acreditamos apenas não ter sido até aqui, atribuído real valor de uso; ou este valor não teria sido ainda compreendido em sua real dimensão, a ponto de se expandir como hegemonia que melhor estabelece a plenitude política dos homens. 


\subsection{Valor Gnoseológico}

Cabe neste ponto colocar como questão a possibilidade de reconhecer na esfera das manifestações culturais subalternas qualquer indicativo de cientificidade e como justificá-lo. A princípio faz-se necessário suplantar a escala da caducidade que o tempo imprime sobre a vida das coisas. É mediante esta escala que constantemente mostra-se a tendência a conceber o avanço no tempo relacionado à melhoria de qualidade. Por esta tendência voltamos, ciclicamente sem sucesso a perscrutar as articulações das civilizações antigas para compreender a forma pelas quais algumas idéias se perpetuam. Mas, a empreitada se faz desnecessária diante do que se apresenta hoje, na tela da pós-modernidade. Pelas vias do pensamento neoliberal, o que pertenceu ao passado deve ter valor de relíquia e o que avança com o tempo tem valor de moderno ou atualizado. Mesmo o olhar para o passado é constantemente reatualizado conforme a mídia predominante e, à ambos os valores os respectivos custos. Assim como na festa popular subalterna se abrem as cortinas da caducidade do tempo e, o que foi experimentado no passado encontra ambiente propício no presente assim se comunicam; também nas manifestações que são próprias da festa reconhecemos este valor historicista que dá conta de uma ordenação sóciocultural onde os sujeitos não necessitam de uma ordem ou poder que determine como e quando algo deve surgir e por quanto tempo deve se manifestar, como no caso de correntes de pensamento e de comportamentos que eventualmente se verificam: corrida armamentista, a cultura do "G" (G8, G20 etc.), globalização etc. Há por assim dizer, possibilidade implícita na necessidade. Não se explica a necessidade, mas realiza-se objetiva ou subjetivamente na possibilidade que se apresenta. Queremos afirmar que valor gnoseológico corresponde no indivíduo à capacidade própria de interpretar o mundo, principalmente quando determinada prática pode ser historicizada. Sendo assim chamamos a atenção para o fato de que tenhamos passado depressa demais, pelo que identificamos como conteúdo ideológico implícito nas manifestações expressivas da cultura. Cremos que seja através deste conteúdo que dialogam os planos, político referente às relações sociais; histórico, pelo reconhecimento da existência em algum lugar ou alhures; e, o 
econômico pela forma de se produzir e se auto-reproduzir. Se suplantada esta caducidade, devemos passar a superação da insistência na aplicação de eixos comparativos ao medirmos os fenômenos sociais. Sem se desconsiderar a questão de toda complexidade das relações humanas, colocamos em questão o que consideraremos um retorno ao que foi problematizado. Ao passar para a alçada das complexidades e deliberadas a respeito em gabinetes fechados de salas acadêmicas, das empresas, escritórios governamentais etc., distanciamse na mesma proporção do ambiente Percorrem um período de formatação de projetos que são aplicados de fora, em doses, à medida das estratégias de dominação ou das mais agudas queixas. ${ }^{302}$

Questionamos se o que realmente vale não é a humanização das sociedades e dos sujeitos. Se para tanto, são somente os avanços tecnológicos e o que passa pelo crivo da cientificidade. Vantajoso, moderno, aprimorado, eficiente, especializado e satisfação garantida até que se divulgue algo mais avançado e fetichizado, para confranger os que estão fora da linha do acesso.

Perguntamos se para se sublevar o valor gnoseológico nos modelos não é preciso inclusive se superar a medida do valor de troca no que concerne a compensação do tempo investido nas problematizações. Ou seja, se todo o trabalho de levantamento, análises e de comprovações realizados sobre os fenômenos poderão ser revertidos em ações representativas. Assim, encontramo-nos diante de um processo de avaliação que conferirá a algum poder constituído e, de quando em vez, especializado, a responsabilidade de julgar quais as teorias mais sustentáveis.

O valor gnoseológico defendido aqui corresponde às experiências próprias da vida de cada indivíduo e de seu grupo. Também pela capacidade de preservar destas experiências, um saber de como se articular com o tempo e a materialidade - um saber viver. Não é isto mesmo uma ciência. Apesar do peso de senso-comum desta argumentação, demandamos que da complexidade das relações humanas os cientistas podem iluminar fenômenos particulares, mas a vida não espera da ciência. Devemos admitir, por exemplo, no caso de civilizações dizimadas pela eugenia, os esclarecimentos científicos

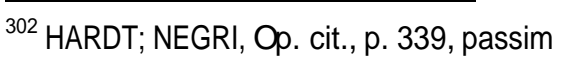


chegaram um tanto tarde. Portanto, complexas ou distintas, entendemos que algumas práticas sociais culturais já se encontram salvaguardas filosoficamente por justificar certo grau de humanização, mesmo que em breves e não tão freqüentes momentos. Justificam-se estas práticas, pois, diversamente a ordem dos fetichismos, mesmo simples e diferente para cada povo pertence a sentido da universalidade. Pertence a todos indistintamente e não prescreve acúmulo material.

lluminar é certamente um verbo que causa rumor se for referenciado aos princípios do Iluminismo. Não virá deste período histórico o cientificismo que classifica os fenômenos das relações humanas pelo grau de complexidade, ou mais rebuscadas conceituações. Insistimos, porém no sentido lato, clarear, iluminar para se ver melhor, enxergar. Abarcar sensível e cognitivamente os aspectos da apreensão. Iniciamos, considerando a idéia de caminho a percorrer. Este caminho deve ser iluminado por um sentido. Uma ideologiapolítica do ser humano elaborada na cultura que se cristaliza no fazer juntos que se possa preservar em qualquer sociedade. Por isso postulamos o sentido de convergência das festas populares subalternas e a ideologia do deslocamento pertinente às atividades humanas, evidenciada nas manifestações expressivas da cultura.

Dos laboratórios transnacionais surgem tecnologias para a comunicação, para a medicina, para novos avanços tecnológicos e para a guerra. Tivemos oportunidade neste trabalho de propor como atributo de armas ideológicas, as condutas que leva o indivíduo a criar um universo no qual se articula com suas próprias concepções - subjetividades. Não é sem consciência que o fizemos e que também não tenhamos e conta os efeitos que tal proposição pode causar. Se julgada hipotética ou conjectural pode não chegar a deflagrar qualquer rumor acadêmico. A despeito de ambas as possibilidades, acrescentamos que não se trata de alguma novidade na luta contra a alienação global do indivíduo humano. Nas estratégias aplicadas à tecnologia da informação encontramos, por exemplo, a palavras torpedo para designar a velocidade e a eficiência com que uma mensagem atinge seu destinatário. Importa, porém que estamos empenhados neste trabalho em conferir fundamentações a deslocamentos de indivíduos e sociedades através de modos comportamentais culturais que, 
como qualquer atividade de produção não se realiza sem que em seu movimento se articulem os impulsos do serpolítico, econômico, filosófico.

Quanto ao conceito de valor, teorizamos, se cientifico, como conhecimento, não se efetivará se não equivaler à transformação de sua circunstância. No que corresponde ao que de inicio analisamos como retorno das problematizações aos que foram seus objetos, deve simbolizar um impulso que movimenta 0 cotidiano ao introduzir neste, estímulos subjetivos. O valor simbólico do conhecimento é assim sem dúvida um mecanismo de deslocamento. Ao ser destacado nas manifestações culturais subalternas, mediante o quadro que se pinta da atualidade, em cujo centro vai o gênio da dominação, transforma-se em dispositivo de sublevação dos homens das mulheres das crianças e dos idosos. Pela iminência dos processos de esgotamento, não estaríamos já diante da crucialidade das duas alternativas: sucumbir, esperando que os representantes das nações mais ricas decidam quando cessar a emissão de gases nocivos na atmosfera, quando cessar a guerra, quando cessar a discriminação global; ou, articular um movimento de reversão deste quadro transferindo o poder das decisões às iniciativas que possam representar consciência social? Para esta articulação não serão necessários dispositivos que próprios da criatividade humana? Assim sendo, não seria este o momento então de termos nossas armas ideológicas de valor gnoseológico - as subjetividades das relações humanas - empunhadas contra a alienação e o conformismo? 
This document was created with Win2PDF available at http://www.win2pdf.com.

The unregistered version of Win2PDF is for evaluation or non-commercial use only.

This page will not be added after purchasing Win2PDF. 


\section{CONCLUSÕES PRELIMINARES}

Procuramos neste trabalho compreender as relações humanas, hora da perspectivas do sujeito para o mundo e também no seu reverso, quando o objeto torna se uma determinante a despeito de um apagamento do sujeito.

Acreditamos haver entre as instâncias, sujeito e mundo objetivo, relações de propriedade e de reciprocidade, de forma constante e ininterrupta. Em determinados momentos parecem perder o impulso devido a um arrefecimento na força social que resulta da vitalidade dos sujeitos. Mas, em minuciosas investigações, pode-se reconhecer e evidenciar que há, igualmente, constantes reivindicações pela reestruturação do ambiente propício para tal vitalidade. Em nosso entendimento, reivindicações pela reestruturação das propriedades reais das relações de trabalho. Por isso consideramos necessária, maior acuidade na observação das oportunidades de humanização do sujeito naquelas manifestações culturais subalternas. Concluímos que os valores morais, que já não se constatam na esfera política, com a qual se pretende demonstrar esforços de humanização, estão nelas contidos. A responsabilidade individual, a qual tivemos oportunidade de colocar como questão, na formação educacional, instituída ou não, também se torna passível de desenvolvimento neste ambiente de coletividade, tanto no que diz respeito à realização da festa popular subalterna, quanto na expressividade das manifestações que lhes são próprias. Nas atuais sociedades de consumo, que se desdobram para assegurar relativo, bem-estar materia $\left.\right|^{303}$, toda a atenção é dispensada para o que poderá funcionar neste sentido. Argumentamos que as pesquisas quantitativas, numéricas, apenas informam sobre um apanhado geral de dados sobre quantos indivíduos se incluem ou não nesta ou naquelas condições. Apenas conseguem, em nosso entendimento, corroborar com as administrações públicas, indicando para onde devem ser desviados os investimentos. Somente os argutos inquiridores dos esquemas de dominação escaparam a esta praxe. A história nos legou seus nomes e, seus escritos

\footnotetext{
${ }^{303}$ HELLER, Agnes, Op. cit., p. 116
} 
estão gravados para que, através deles possamos conhecer a teoria, a metodologia e a ideologia de uma filosofia praxística alternativa.

Quando um estudo adentra a área das ciências humanas não há como fugir ao fato de que fazemos um exame de nós mesmos e de nossas sociedades. Os índices certamente servem para dar demonstração do quanto, determinadas problemáticas ou fenômenos se repetem ou evoluem; do quanto atingem a sociedade; a comunidade indissolúvel entre sujeito e objeto, e entre fatos e valores, são chaves reais, das quais o pesquisador não pode nem deve prescindir. O pesquisador não deve em nenhum momento abrir mão da paixão, contudo, sua experiência pessoal, sem se traduzir em somas e números medianos, deve suplantar o academicismo que prescreve satisfação ao pretenso sábio e às corporações que reverenciam aos dados quantitativos. ${ }^{304}$

Asseveramos que os fatos e valores têm sido estabelecidos e predeterminados conforme uma diretriz liberal. Também não há qualquer dificuldade em se distinguir através de quais mecanismos essa diretriz é promulgada. Portanto, cabe a quem decidir pensar a respeito deste estado de dominação, não somente medir com números a extensão do problema, mas, como e quem deve agir para mudar o próprio pensamento.

As sociedades consumistas regurgitam celebridades que se evidenciam através dos índices de audiência. Numericamente, espectadores, ouvintes, compradores de livros e de discos dão a conta do efeito midiático alienante e conferem veracidade aos fenômenos sociais. Enquanto muitos indivíduos suprematizam algumas classes, como a de intelectuais e de artistas televisivos, também os colocam como exemplos no horizonte longínquo. Na forma de uma utopia cega, coagulam-se as possibilidades de liberdade e de criatividade que na dimensão da subalternidade se exemplifica na atitude de aprender com a sua própria experiência de vida. ${ }^{305}$

É imprescindível admitir que à medida do desenvolvimento de um diálogo com pensadores e autores, passamos então, a ter olhos e ouvidos mais atentos, o senso crítico estimulado é possivelmente, tocado ideologicamente. Entretanto

\footnotetext{
${ }^{304}$ TODOROV, Op. cit., p. 11

${ }^{305}$ BAUMAN, Op. cit., p. 64
} 
uma grande dificuldade encontrada foi em se compreender as burocracias e entraves quando, neste caso particularmente, um professor da rede estadual de ensino, se predispõe ao trabalho de pesquisa científica. Primeiro, como um funcionário público, não pode pleitear bolsa de estudo - deve se contentar com as medidas do Estado; depois deve dividir o trabalho de pesquisa com as atividades escolares. Não é raro se defrontar com o julgamento dos que se dizem autoridades na área da Educação, de que o aprimoramento intelectual é um luxo em se tratando do Ensino Público. Outra grande dificuldade encontrada é que desenvolvemos o trabalho de pesquisa, que a princípio deve ter um espírito de abertura, ou seja, deve se estender às pessoas, dentro um ambiente quase sempre inóspito por se tratar da hegemonia que domina. Aqui, como em outras teorias, compreendemos o dever de repensar do próprio Estado. Da mesma forma, como os objetivos são os de transformação a sociedade. Sendo assim, pela hegemonia dominante somos impulsionados à pensar caminhos alternativos enquanto, ao mesmo tempo sofremos seus imperativos.

Mediante a voga da preservação dos costumes, constatamos que muitas coisas são feitas. Ao mesmo tempo, percebe-se que, na maioria dos casos que dizem respeito à relação com a cultura e em seu interior, não há preocupação com o ambiente e com a ideologia em função de qualquer preservação - de qualquer atividade humana, a razão em si. O aprendizado relativo à disciplina escolar não é tão significativamente promissor quanto à garantia do convívio com a atividade, por isso reclamamos atenção maior a questão desta relação. Entendemos serem necessárias garantias, pelo menos do ambiente e, por conseguinte da ideologia que ampara o auto-movimento. Se se comprova historicamente, uma base ideológica para o que até aqui, se considerou como resistência, atribuída as propriedades das manifestações culturais das classes subalternas, comprova-se também sua eficácia. Assim concluímos que deverá ser desenvolvida e aplicada uma metodologia de abordagem, de exames e de práxis, que desloque o que se estagnou como valor identitário e se-lhe restitua o movimento enquanto cultura própria. Que se desenvolva metodologia praxística na qual se estabeleçam como armas ideológicas as subjetividades do mundo do trabalho - dispositivos de combate aos sistemas que coagulam o 
fluxo de pensamento petrificando a criatividade. Estão em jogo a liberdade, as necessidades e as possibilidades. Como formas de compreensão da vida e do mundo, correspondem sempre à possibilidade de compreensão do ambiente. Comprovamos que os movimentos de reciprocidade e de propriedade estão compreendidos nas relações materiais. A estas relações conotam as subjetividades pelas quais a consciência procura explicar e conceber os fenômenos próprios da natureza. Portanto, considerada a diversidade das possíveis interpretações do mundo pela concepção do homem, é do mundo de suas atividades de onde se poderá haurir quaisquer qualidades que se elevem às de humano-genérico e a de particular- universal. Consideramos, com plena consciência dialética, que o simples é a revolução do complexo, pois o nega enquanto o explica gerando nova complexidade. Por isso ainda, parecer inconcebível que a subalternidade, superando ao conceito de classe, como força imanente, componha o fluxo vital do organismo: sociedade. Como força, sua massa energética em movimento é a cultura, pois abarca toda a atividade humana - diferente conforme as relações materiais, conforme o trabalho.

Onde acreditamos não haver necessidade de resistência é quanto à entrega do conceitual ao prático. A assimilação das posturas de propriedade e de reciprocidade, também entre intelectuais (problematizadores) e os objetos que são pela atividade daqueles, trocados em miúdos para a compreensão da massa. Estas, em nosso entendimento, devem representar a ideologia pressuposta em oposição à atribuição de valor de mercado ao conhecimento. Esta atribuição, de forma hegemônica, predetermina o destino das coisas. Tudo ou quase tudo já nasce pré-relacionado a um preço: quanto custa formar o indivíduo do ensino básico ao superior para que seja um valor ativo economicamente? Fragmentação e unilateralidade, na visão do que se compreende como formar. Acreditamos que a formação cultural somente se completa nas relações humanas e quando se alimenta de sua própria substância. Em outras palavras, a cultura não pode se resumir na relação artista/público, nem distribuída conforme a divisão por classe, como estipula a indústria cultural; ela, inevitavelmente se amplia e abrange toda a cotidianidade, no trabalhar e celebrar; no se alegrar e se entristecer; no comunicar e apreender; na propriedade e na reciprocidade. 
A partir das possibilidades de identificação e de explicitação de acordo com Agnes Heller (2004), também identificamos a metodologia cuja dialética permite conceber relações sem a presença da noção de valor de troca. Referimo-nos ao que é feito sem fugir a integridade do indivíduo, além de ser necessária, até mesmo como divertimento, mas, ainda assim propenso às relações de produção, portanto da vida sócio-econômica.

Reconhecendo hoje a portabilidade, não é difícil considerar a velocidade com que o saber, comprimido como informação, viaja no tempo e no espaço solapando experiências sócio-culturais próprias à exemplo das nações latinoamericanas, que apesar do processo violento de colonização, têm nas reservas das matrizes africanas, de seus povos originários e a posteriori, de toda a miscigenação, expressos na cultura, rico conteúdo político ideológico.

Selecionamos para as nossas observações duas formas de manifestação popular subalternas, a Dança do Moçambique e o Jongo bem como os ambientes que Ihes são próprios para sua origem o rural do Vale do Paraíba pela cotidianidade histórica e o ambiente das festas populares subalternas para sua explicitação. Tivemos, contudo a consideração de que as descrições históricas sobre estes objetos, superficiais ou profundas já foram por restritas visões, realizadas. Neste quadro não foi difícil destacar, a partir das proposições metodológicas e de um amparo filosófico, as oportunidades, às quais nos referimos antes, como de humanização do sujeito. Interessou-nos acima e mais do que tudo compreender a respeito dos processos em que se dá esta humanização. A compreensão de uma política do sujeito para o sujeito subjetividades. Esta política se opõe severamente a perspectiva de que o povo não deve extrapolar sua condição. Quando ouvimos que, determinados produtos são destinados ao povão (um pejorativo para grande massa ou, para a maioria das pessoas de uma sociedade), isto quer dizer que existe uma cultura que não é a do povo e que existem indivíduos que não fazem parte deste conjunto. Assim, entendemos que, por este mesmo motivo, nunca ser revelada e muito menos aplicada à política a moral subalterna; prevalece a hegemonia da dominação. 
Concluímos pela necessidade de se esclarecer mais amplamente que formar o indivíduo diverge absolutamente de torná-lo hábil consumidor, deve convergir para a concepção de homem como auto-criador ${ }^{306}$.

Conjecturamos que se um dia a humanidade não pisar mais sobre o solo terrestre e se transformar em cosmopolita do tempo e do espaço ainda assim estará em busca de reconhecer e comunicar aos outros suas noções sobre o universo. Com isso, não duvidamos de que um outro mundo melhor é possível ${ }^{307}$; esta, portanto, continuará sendo, a utopia que nos mobiliza nesta busca.

${ }^{306}$ Ibid., p. 118

${ }^{307}$ HARDT; NEGRI Op. cit., p. 290 
This document was created with Win2PDF available at http://www.win2pdf.com.

The unregistered version of Win2PDF is for evaluation or non-commercial use only.

This page will not be added after purchasing Win2PDF. 


\section{BIBLIOGRAFIA GERAL}

AFANASSIEV, V.G. Filosofia Marxista Compêndio Popular. Rio de Janeiro GB. Vitória, 1963.

ALENTEJO, Eduardo da Silva. Memórias dos Jongueiros do Tamandaré: estratégias de permanência, institucionalização da cultura popular e suas relações de poder. Trabalho de Conclusão de Curso (Mestrado em Memória Social e Documento. Universidade do Rio de Janeiro. Rio de Janeiro, 2005.

ARENDT, Hanna. Entre o Passado e o Futuro. São Paulo: Perspectiva, 1972.

BARBERO, Jesus Martin. De los médios a lãs mediaciones - comunicacion, cultura y hegemonia. Barcelona: Edições G. Gili, 1993

BAUDRILLARD, Jean. Para uma crítica da Economia, Sociedade e Cultura. São Paulo: Paz e Terra, 2000.

BAUMAN, Zygmunt. Comunidade: a busca por segurança no mundo atual; tradução de Plínio Dentzien. Rio de Janeiro: Jorge Zahar Editor, 2003.

BENJAMIN, Walter. A Obra de Arte na época de sua reprodutibilidade Técnica. In Costa Lima, Luiz. (Org.) Teoria da Cultura de Massa. Rio de Janeiro 1978

BENJAMIN, Walter. Magia e Técnica, Arte e Política. São Paulo: Ed.

Brasiliense, 1984.

BETHELL, Leslie. A América Latina entre a segunda guerra mundial e a guerra fria. São Paulo: Paz e Terra S/A, 2004.

BORON, Atilio A.. Nova Hegemonia Mundial. Buenos Aires: Consejo Latinoamericano de Ciências Sociales, 2004.

BOSI, Eclea O Tempo vivo da memória: ensaios de psicologia social. São

Paulo: Ateliê Editorial, 2003.

Memória e Sociedade: a memória dos velhos. São Paulo: Cia da

Letras, 1994.

BRENNAN, Barbara Ann. Mãos de Luz. São Paulo: Ed. Pensamento, 1987.

CAMPOS, Judas Tadeu de Currículo e Cultura: A formação do Caipira. 2002. Dissertação Doutorado em Educação - Currículo. PUC/SP - São Paulo.

CECEÑA, Ana Esther. Los Desafios de las Emancipaciones en um Contexto Militarizado. Buenos Aires: CLACSO, 2006. 
FERREIRA, Maria Nazareth Alternativas metodológicas para a produção científica. São Paulo: CELACC-ECA/USP, 2006.

As festas Populares na expansão do Turismo: a experiência italiana. São Paulo: Arte \&Ciência - Villipress, 2001.

(Org.) Globalização e Identidade cultural na América Latina. São Paulo. CEBELA, 1995

"in" Por uma cultura Latinoamericana - AMARAL , $R$. et elii. Comunicação de Massa: O impasse Brasileiro. Rio de janeiro: ForenseUniversitária, 1978.

GARCIA , Néstor; RONCAGLIOLO, Rafael. Cultura transnacional \& Cultura popular. Lima: IPAL, 1988.

GONZÁLEZ-MANET, Enrique. Nuevas Formas de Comunicación y Cutura: como enfrentar las Nuevas Tecnologias? Revista Comunicação \& política: comunicação na América Latina CBELA - Centro Brasilerio de Estudos Latino Americanos Ano XIII № 22-23-24-25. São Paulo, 1993.

GRAMSCI, Antonio. Concepção Dialética da História. Rio de Janeiro: Civilização Brasileira, 1966.

HALL, Stuar. A identidade cultural na pós-modernidade. Rio de Janeiro: DP\&A, 2006.

HARDT, Michael; NEGRI, Antonio. Multidão. Rio de Janeiro: Record, 2005

HEGEL, Georg Wilhelm Friedrich. Fenomenologia do Espírito. São Paulo:

Vozes, 2003.

HELLER, Agnes. O Cotidiano e a História. São Paulo: Paz e Terra S/A, 2004.

KANT, Immanuel. Critica da Faculdade do Juízo. Rio de Janeiro: Forense Universitária, 2005.

LANDER, Edgardo. A Colonialidade do Saber - Eurocentrismo e Ciências Sociais. Buenos Aires: CLACSO, 2005.

LEFEBVRE, Henri. La presencia y la ausência. México: Fondo de Cultura Economica, 1983.

LUKÁCS, Georg. História e Consciência de Classe. São Paulo: Martins Fontes, 2003.

MARX, Karl. Formações Econômicas Pré-capitalistas. Rio de Janeiro: Paz e Terra, 1981 
MARTINS, José de Souza. A aparição do demônio na fábrica, no meio da produção. São Paulo: Rev. Socio. USP. 1993.

MATELLART, Armand e Michèle. História das teorias da comunicação. São Paulo: Edições Loyola, 1999.

MINDLIN, Betty. Diários da Floresta. São Paulo: Terceiro Nome, 2006.

PORTELLI, Hugues, Gramsci e o bloco histórico, tradução Angelina Peralva, Rio de Janeiro: Paz e Terra, 1977.

SAID, Edward W.. Cultura e Imperialismo. São Paulo: Companhia das Letras, 2000.

SEMERARO, Giovanni. Gramsci e os novos embates da filosofia da práxis. Aparecida, SP: Idéias e Letras, 2006.

SHILLERS, Friedrich. A Educação Estética do Homem (numa serie de cartas), São Paulo - SP: Ed. lluminuras, 2002.

SODRÉ, Muniz. Reinventando a Cultura a Comunicação e seus produtos. Petrópolis, RJ: Vozes, 1996.

XIDIEH, Oswaldo Elias. Narrativas Populares. São Paulo: Itatiaia, 1993.

TODOROV, Tzvetan. Nós e os outros: a reflexão francesa sobre a diversidade humana. Rio de Janeiro: Jorge Zahar Ed.,1993. 
This document was created with Win2PDF available at http://www.win2pdf.com.

The unregistered version of Win2PDF is for evaluation or non-commercial use only.

This page will not be added after purchasing Win2PDF. 
ANEXOS 
- ROTEIRO DE QUESTÕES PARA OS LÍDERES DE MOÇAMBIQUES E JONGUEIROS

1 - QUAL A COMPARAÇÃO QUE PODE SER FEITA DA SUA ATIVIDADE HOJE COM RELAÇÃO AO PASSADO?

DO MEIO RURAL PARA O URBANO.

OS ASPECTOS POSITIVOS E NEGATIVOS

2 - QUE SIGNIFICADO TEM PARA VOCÊ ESTA ATIVIDADE? QUAL O SIGNIFICADO DOS ACESSÓRIOS (APARELHOS)?

RELIGIOSO;

HERANÇA CULTURAL PATERNA;

ESPETÁCULO;

TRABALHO.

3- COMO CONSIDERA A ATUAÇÃO DO PODER PÚBLICO OU OUTRO TIPO DE ORGANIZAÇÃO JUNTO A SUA ATIVIDADE? BOA OU RUIM E EM QUAL SENTIDO?

4 - QUAIS AS PRINCIPAIS DIFICULDADES ENCONTRADAS? COMO A PESSOA PASSA A FAZER PARTE?

5 - COMO ANALISA O QUE AS PESSOAS PENSAM DE SUA ARTE? EM RELAÇÃO A QUEM ASSISTE E QUEM PARTICIPA?

O QUE ACRESCENTA À VIDA DAS PESSOAS? QUEM ASSISTE E QUEM PARTICIPA? 
- ROTEIRO DE QUESTÕES PARA OS FESTEIROS

1 - POR QUE CHAMAR OS GRUPOS DE DANÇA DO MOÇAMBIQUE PARA A FESTA? COMO OBSERVA A APRECIAÇÃO DAS PESSOAS?

2 - QUAL A SUA CONSIDERAÇÃO PESSOAL A ESTAS EXPRESSÕES?

3 - QUAL A RELAÇÃO DA MANIFESTAÇÃO EXPRESSIVA COM A FESTA? 
- Complementação da Nota sobre Antonio Gramsci

"[... Nascido na Sardenha, em 1891, filho de camponeses pobres, Gramsci deixou a sua atrasada terra natal em 1911, deslocando-se para Turim. Já naquela ocasião ele participava ativamente da luta dos trabalhadores italianos. Em Turim, esta participação se aprofunda, "o vinculo de Antonio Gramsci com os operários de Turim - escreveu Togliatti - não foi somente um vinculo político, mas um vínculo pessoal, existencial".

Em 1915, já Gramsci dirigia o jornal da secção socialista de Turim. A guerra européia de 1914-18 coloca os dirigentes do movimento operário em face de opções decisivas: aderir à guerra ou opor-se a ela? Gramsci assume a segunda posição e combate as provocações dos belicistas. Recusa-se a reconhecer $o$ direito de negocistas e politiqueiros transformarem os trabalhadores italianos em carne para canhão.

Em agosto de 1917, os operários de Turim se insurgiram e pegaram em armas para enfrentar o militarismo italiano, mas foram derrotados pela repressão, com cerca de 500 mortos e mais de dois mil feridos. Logo após a insurreição e com a tarefa básica de reorganizar o movimento socialista, Gramsci foi eleito secretário da secção regional do Partido Socialista.

Foi nesta condição de dirigente máximo do movimento socialista na "cidade vermelha" que ele saudou a vitória da revolução bolchevista na Rússia. Pondo em prática os desenvolvimentos trazidos por Lénine ao marxismo, e adaptando-os criticamente à situação particular da Itália. Gramsci organizou os "conselhos de fábrica" e fundou a $1^{\underline{a}}$ de maio de 1919, o jornal destes conselhos: L'Ordine Nuovo. Em luta incessante contra o oportunismo social-reformista e contra o "esquerdismo", Gramsci veio a se tornar o dirigente máximo do Partido Comunista Italiano, que ajudaria a fundar, em 1921.

A ascensão do fascismo o encontra na liderança de uma oposição firme e lúcida a Mussolíni. Gramsci, de resto, havia previsto a tempestade: "A fase atual da luta de classes na Itália é a fase que precede ou a conquista do poder político pelo proletariado revolucionário e a passagem a uma nova organização da produção que permita um aumento da produtividade, ou uma tremenda reação por parte da classe proprietária e da casta dirigente".

En 16 de maio de 1924, Mussolini, já presidente do Conselho de Ministros, encaminha ao Parlamento Italiano um projeto de lei visando "disciplinar a atividade das associações e institutos". Segundo o projeto - dirigido, na ocasião, contra a maçonaria - as associações ou institutos ficavam obrigados a fornecer ao governo uma lista sempre atualizada de seus 
funcionários, com as respectivas qualificações e endereços. Gramsci, então deputado, pronunciou um discurso no qual punha a nu o caráter antidemocrático do projeto e aproveitava para denunciar as manobras fascistas no sentido de implantar no país uma ditadura.

O próprio Mussolini, irritado, resolveu apartear o franzino corajoso deputado marxista, definindo a fascismo como uma "revolução". Gramsci retrucou-Ihe que fascismo não era uma revolução, mas uma "simples substituição de um pessoal administrativo por outro". "Só é revolução acentuou - aquela que se baseia em uma nova classe; o fascismo não se baseia em nenhuma classe que já não esteja no poder".

Mussolini voltou à carga, procurando descaracterizar o conteúdo de classe do fascismo e protestando: "Grande parte dos capitalistas está entre nós!”. O deputado oposicionista não se perturbou, e observou que o fascismo só entrava em choque agudo com os outros partidos e organizações da burguesia (como estava acontecendo com a maçonaria) porque queria estabelecer o monopólio da representação da classe. A atitude do fascismo com relação aos demais partidos era simples: "primeiro Ihes quebra as pernas e, depois, faz acordo com eles em condições de evidente superioridade".

Mussolini não gostou da referência à violência dos fascistas, retrucando que esta violência equivalia à dos comunistas. Gramsci Ihe respondeu: "A vossa violência é sistemática e é sistemàticamente arbitrária, porque vós representais uma minoria destinada a desaparecer". A frase, naquela ocasião, era bastante ousada de vez que o fascismo estava em pleno fortalecimento. Vinte anos mais tarde, contudo, ela foi confirmada pelos fatos. Antes da minoria fascista desaparecer, porém, implantou-se na Itália a sua ditadura e em 8 de novembro de 1926, Gramsci foi preso, por ordem de Mussolini. No processo-farsa que o Estado fascista Ihe moveu, o promotor pediu aos juízes que Gramsci fosse condenado, alegando: "É preciso impedir este cérebro de funcionar". A condenação veio, mas não conseguiu impedir que o cérebro funcionasse: de dentro do cárcere, Gramsci continuou a observar o país e o mundo de seu tempo.

Durante quase onze anos, Gramsci viveu na prisão, em meio a sofrimentos inenarráveis, com o débil organismo minado pela insalubridade carcerária, pela guerra de nervos, pela insônia e pela tuberculose. Mas não ficou inativo, não se entregou às angústias e à depressão. Procurou entrar em contato com os companheiros encarcerados e, quando o conseguiu, deuIhes assistência e orientação. Escreveu numerosas cartas para sua cunhada Tatiana Shucht, para sua mãe, para seus filhos Délio e Giuliano ( $O$ menor dos quais não chegou se quer a conhecer). Acompanhou com 
desvelo a evolução da doença nervosa de sua mulher, Gulia Shucht. Enão interrompeu seus estudos e reflexões, lendo o que seus carcereiros the permitiam, anotando fragmentariamente suas observações em cadernos manuscritos, trinta e dois dos quais conseguiram escapar à sanha fascista de destruição. Em dado momento, sabendo que o seu tenaz adversário estava doente, Mussolíni Ihe mandou um emissário, sugerindo que Gramsci Ihe formulasse um pedido de clemência, que êle prometia atender. Gramsci repeliu a manobra: "O que propondes é o meu suicídio político; e eu não tenho a menor intenção de fazêlo". Quando Gramsci morreu, em 27 de abril de 1937, - poucos dias após a sua libertação, ordenada por Mussolíni para evitar que a sua morte na cadeia abalasse 0 prestígio do governo - o líder fascista estava no auge do seu prestígio fora entusiàsticamente elogiado por Wiston Chuchill e costumava ser induído entre os grandes líderes do "Ocidente". Hoje, Mussolíni é um nome desmoralizado, exposto á execração universal, ao passo que Gramsci inspira respeito até mesmo aos seus mais encarniçados adversários.

Benedetto Croce, filósofo cujas formulações Gramsci tanto combateu, não deixou de dizer de Gramsci que "como homem de pensamento, êle foi dos nossos, foi daqueles que, nas primeiras décadas do século chegaram a se formar um critério adequado sobre os problemas do presente". $E$ reconheceu que ele "mantivera alta a dignidade do homem". [...]" - N.A. A inclusão desta extensa nota deve se ao fato de que boa parte dos estudos desenvolvidos na área das Ciências Humanas atualmente não leva em conta a importância da contribuição dos estudos deste célebre autor nas discussões sobre o desenvolvimento da sociedade humana e acima disto seu exemplo de força, de luta, de fidelidade a causa e de perseverança. 
This document was created with Win2PDF available at http://www.win2pdf.com.

The unregistered version of Win2PDF is for evaluation or non-commercial use only.

This page will not be added after purchasing Win2PDF. 